\title{
Sediment Quality of Lakes, Rivers, and Estuaries in the Mystic River Basin, Eastern Massachusetts, 2001-03
}

By Robert F. Breault, John L. Durant, and Albert Robbat, Jr.

In cooperation with the

Massachusetts Department of Environmental Protection,

Massachusetts Department of Conservation and Recreation, and

Tufts University

Scientific Investigations Report 2005-5191 


\section{U.S. Department of the Interior \\ Gale A. Norton, Secretary \\ U.S. Geological Survey \\ P. Patrick Leahy, Acting Director}

U.S. Geological Survey, Reston, Virginia: 2005

For sale by U.S. Geological Survey, Information Services
Box 25286, Denver Federal Center
Denver, CO 80225
For more information about the USGS and its products:
Telephone: 1-888-ASK-USGS
World Wide Web: http://www.usgs.gov/

Any use of trade, product, or firm names in this publication is for descriptive purposes only and does not imply endorsement by the U.S. Government.

Although this report is in the public domain, permission must be secured from the individual copyright owners to reproduce any copyrighted materials contained within this report.

Suggested citation:

Breault, R.F., Durant, J.L., and Robbat, Albert, Jr., 2005, Sediment quality of lakes, rivers, and estuaries in the Mystic River Basin, eastern Massachusetts, 2001-03: U.S. Geological Survey Scientific Investigations Report 2005-5191, $110 \mathrm{p}$. 


\section{Contents}

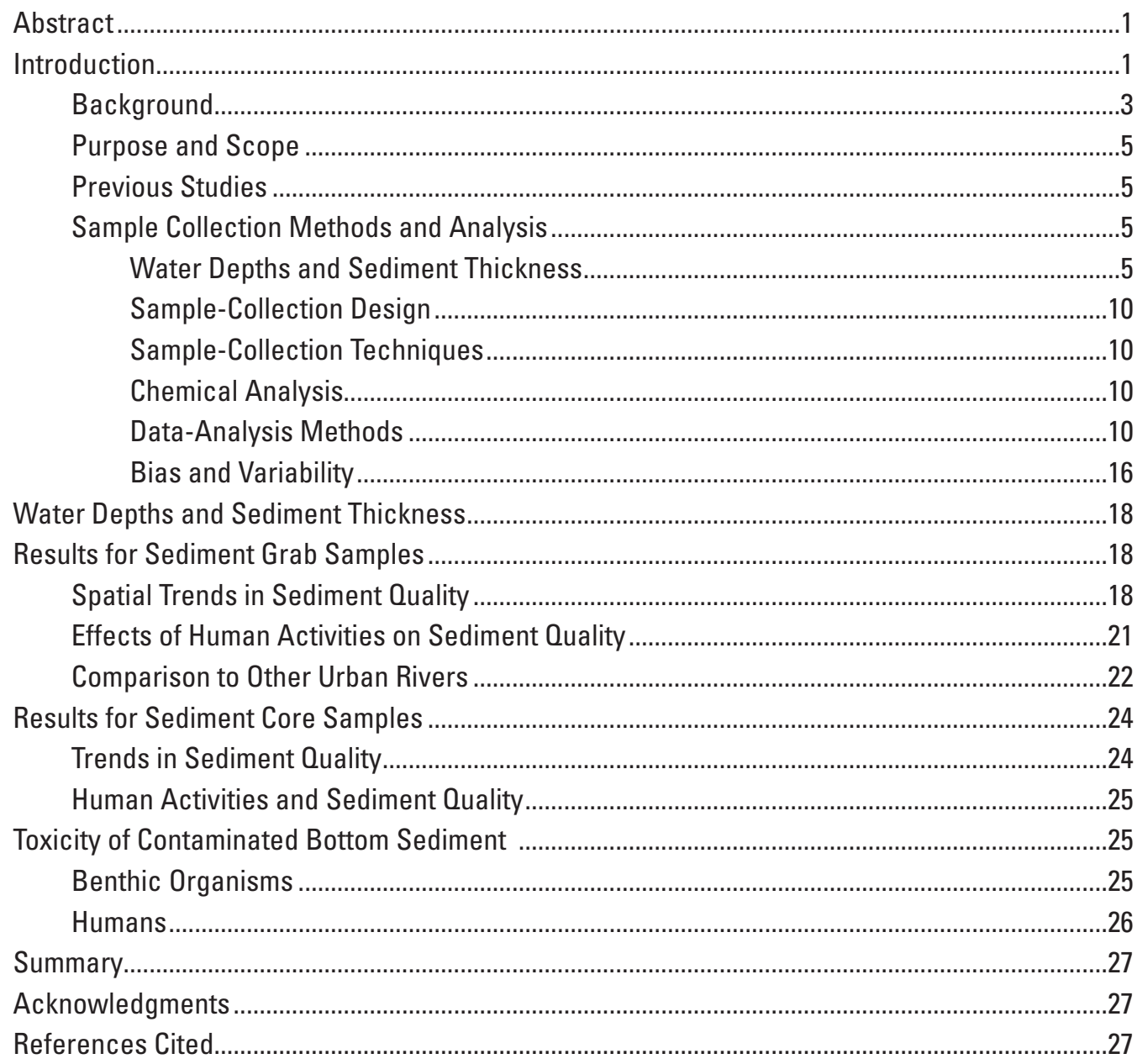

\section{Figures}

1. Map showing the location of the Mystic River Basin, Massachusetts..............................2

2. Photographs showing $A$, tugboat operation; $B$, shipping; $C$, typical industry; and $D$, remedial action on a contaminated waterway in the lower Mystic River, Massachusetts.

3, 4. Maps showing:

3. Sediment grab and core sampling locations, Mystic River Basin .9

4. Altitude of streambed, sediment thickness, or both in the Mystic River Basin: $A$, Lower Mystic Lake; $B$, Alewife Brook and its confluence with the upper Mystic River; and $C$, upper Mystic River and the Malden River above the Amelia Earhart Dam. 
5, 6. Photographs showing:

5. A, U.S. Geological Survey personnel collecting a sediment grab sample; $B$, sediment collected in the dredge; $C$, transfer of sediment sample from the dredge into a Teflon bag; and $D$, a waterlogged sediment sample collected from the lower Mystic River

6. $A$, Dry ice being placed into freeze corer; $B$, retrieval of freeze corer; $C$, removal of excess sediment from corer; and $D$, sediment-core preservation by wrapping the core in plastic.

7. Graph showing population statistics for element and polyaromatic hydrocarbon concentrations measured in grab samples collected from the Mystic River Basin, and other urban rivers (2001-03)

8. Map showing areas dredged as part of the Boston Harbor Navigation Improvement Project, in which the lower Mystic River and Inner Harbor were deepened from 35 feet mean lower low water (MLLW) to about 40 feet MLLW (light blue) and parts of Chelsea Creek from 35 feet MLLW to about 38 feet MLLW (dark blue).

9-16. Graphs showing:

9. Selected trace element and organic compound concentrations measured in sediment core samples collected from site 105, Lower Mystic Lake, Mystic River Basin

10. Selected trace element and organic compound concentrations measured in sediment core samples collected from site 106, upper Mystic River above Amelia Earhart Dam, Mystic River Basin .

11. Selected trace element and organic compound concentrations measured in sediment core samples collected from site 107, Malden River, Mystic River Basin

12. Selected trace element and organic compound concentrations measured in sediment core samples collected from site 108, upper Mystic River about 180 meters above the Amelia Earhart Dam, Mystic River Basin

13. Selected trace element and organic compound concentrations measured in sediment core samples collected from site 109, upper Mystic River about 90 meters above Amelia Earhart Dam, Mystic River Basin

14. Selected trace element and organic compound concentrations measured in sediment core samples collected from site 110, lower Mystic River about 45 meters below the Amelia Earhart Dam, Mystic River Basin

15. Selected trace element and organic compound concentrations measured in sediment core samples collected from site 111, lower Mystic River about 475 meters below the Amelia Earhart Dam, Mystic River Basin

16. Selected trace element and organic compound concentrations measured in sediment core samples collected from site 112, Island End River, Mystic River Basin

17. Map showing estimated sediment toxicity to Hyalella azteca and

Chiromonus spp. with respect to consensus-based freshwater sedimentquality guidelines 


\section{Tables}

1. Bottom-sediment sampling sites in the Mystic River Basin, Massachusetts ...................6

2. Constituents analyzed in sediment samples from the Mystic River Basin and their common sources and uses

3. Distribution of element and organic compound concentrations measured in sediment grab samples, Mystic River Basin.

4. Distribution of element concentrations measured in sediment core samples, Mystic River Basin. .76

5. Distribution of organic compound concentrations measured in sediment core samples, Mystic River Basin

\section{Conversion Factors, Vertical Datum, and Abbreviations}

\begin{tabular}{lcl}
\hline Multiply & By & To obtain \\
\hline cubic foot $\left(\mathrm{ft}^{3}\right)$ & 0.0283 & cubic meters $\left(\mathrm{m}^{3}\right)$ \\
cubic yards $\left(\mathrm{yd}^{3}\right)$ & 0.7646 & cubic meters $\left(\mathrm{m}^{3}\right)$ \\
foot $(\mathrm{ft})$ & 0.3048 & meter $(\mathrm{m})$ \\
gallons $(\mathrm{g})$ & 3.785 & liters $(\mathrm{L})$ \\
gallons $(\mathrm{g})$ & 0.134 & cubic feet $\left(\mathrm{ft}^{3}\right)$ \\
inch (in.) & 2.54 & centimeter $(\mathrm{cm})$ \\
inch (in.) & 25.4 & millimeter $(\mathrm{mm})$ \\
inch (in.) & 25,400 & micrometer $(\mu \mathrm{m})$ \\
million gallons (Mgal) & 3,785 & cubic meters $\left(\mathrm{m}^{3}\right)$ \\
\hline
\end{tabular}

Temperature in degrees Celsius $\left({ }^{\circ} \mathrm{C}\right)$ may be converted to degrees Fahrenheit $\left({ }^{\circ} \mathrm{F}\right)$ as follows:

${ }^{\circ} \mathrm{F}=\left(1.8 x^{\circ} \mathrm{C}\right)+32$

Temperature in degrees Fahrenheit ( $\left.{ }^{\circ} \mathrm{F}\right)$ may be converted to degrees Celsius $\left({ }^{\circ} \mathrm{C}\right)$ as follows:

${ }^{\circ} \mathrm{C}=\left({ }^{\circ} \mathrm{F}-32\right) / 1.8$

Vertical coordinate information is referenced to the North American Vertical Datum of 1988 (NAVD 88).

Horizontal coordinate information is referenced to the North American Datum of 1983 (NAD 83).

Altitude, as used in this report, refers to distance above the local vertical datum.

Concentrations of sediment-quality constituents are given in percent $(\%)$, parts per million $(\mathrm{ppm})$, and parts per billion (ppb). 


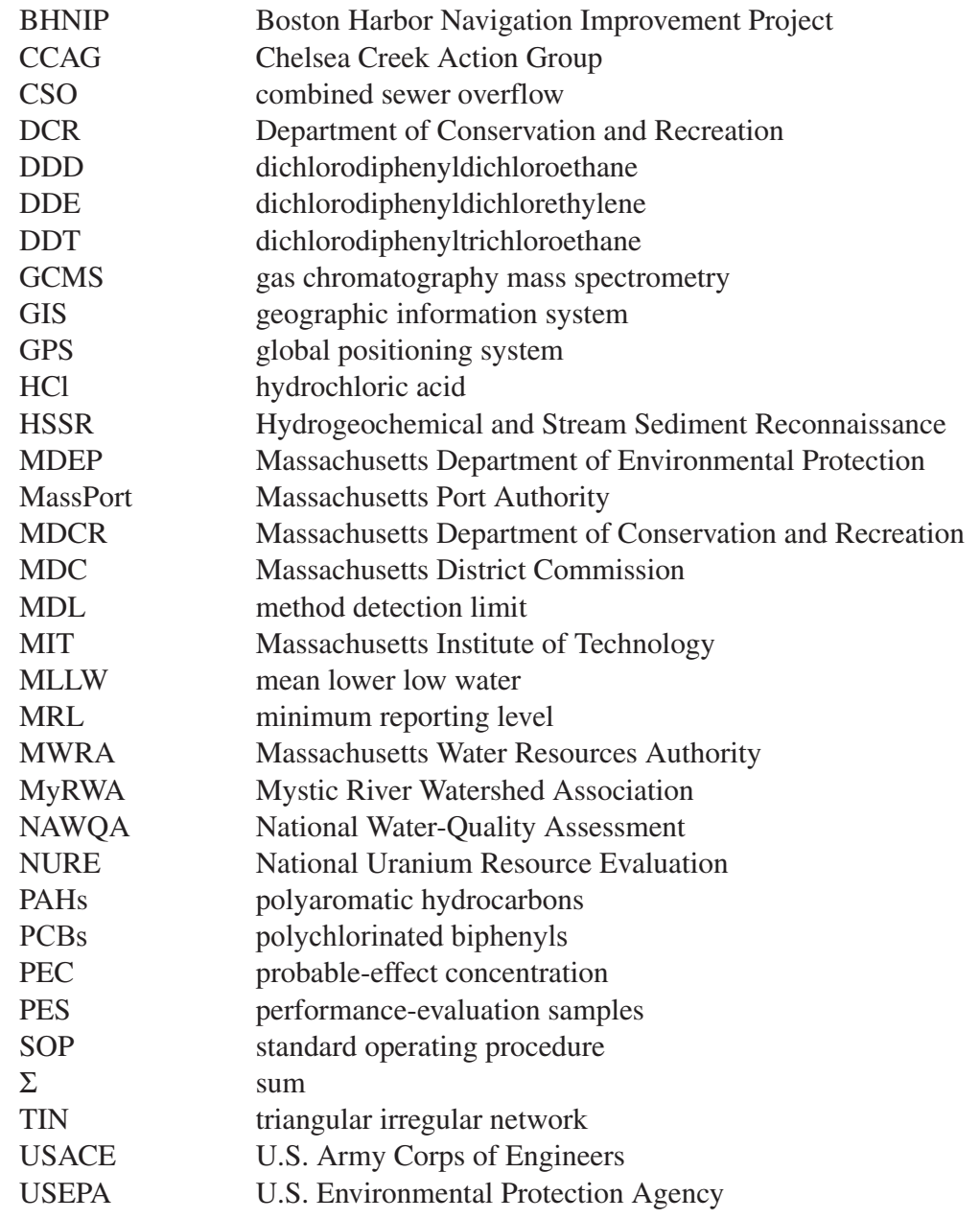




\title{
Sediment Quality of Lakes, Rivers, and Estuaries in the Mystic River Basin, Eastern Massachusetts, 2001-03
}

\author{
By Robert F. Breault', John L. Durantt ${ }^{2}$, and Albert Robbat, Jr. ${ }^{2}$
}

\section{Abstract}

The U.S. Geological Survey, in cooperation with the Massachusetts Department of Environmental Protection, Massachusetts Department of Conservation and Recreation, and Tufts University, completed a study of bottom-sediment quality in selected lakes, rivers, and estuaries in the Mystic River Basin, 2001-03. More than 100 bottom-sediment grab samples and 8 bottom-sediment cores were collected from the study area that included the Lower Mystic Lake, Mystic River, Alewife Brook, Malden River, Island End River, Chelsea and Mill Creeks, and Boston Inner Harbor. Sediment grab and sediment core samples were tested for the presence of pesticides, polyaromatic hydrocarbons (PAHs), polychlorinated biphenyls, and trace elements.

Both types of samples were generally enriched in toxic elements, in particular, arsenic, chromium, copper, lead, silver, zinc, and PAHs with respect to background concentrations and concentrations measured in sediment from other urban rivers. There were only a few detections of pesticides and no polychlorinated biphenyl detections above detection limits. Locally, concentrations of most trace elements and PAHs were lower in the sediments in the Mystic River Basin than in the lower Charles River, but higher than or equal to concentration in the Neponset River, with the notable exception of arsenic. Some chemicals also are in sufficiently high concentrations in Mystic River sediment to pose a threat to benthic organisms and potentially to cause health risks to humans if they come in contact with the sediment. Increasing concentrations with sediment depth in cores show that the deposition of trace elements and PAHs has substantially declined over the past 50 years or so. However, concentrations of PAHs are generally higher in the top few centimeters of sediment, indicating that sediment contaminant concentrations in the basin remain elevated above background.

\section{Introduction}

Restoration of lakes, rivers, and estuaries in the Boston metropolitan area has improved water and sediment quality and has generally made it safer for people to boat, swim, and fish in these waters. For example, during the past 10 years, Federal, State, and local institutions have collaborated to achieve the common goal of restoring the Charles River, a tributary to Boston Harbor (Breault and others, 2000; Zarriello and others, 2003; Weiskel, 2005). This initiative, known locally as Clean Charles River 2005, has realized substantial improvements in the water quality of the Charles River, and now serves as a model for other urban river-restoration projects across the nation. The initiative, which includes waterquality monitoring, collaborative studies, and the removal of illegal sewer connections, has been applied to lakes, rivers, and estuaries of the Mystic River Basin (fig. 1). This new initiative was motivated in part by the former administrator of the U.S. Environmental Protection Agency's (USEPA) New England Office, John DeVillars, who stated: "Our strategy is working *** well on the Charles; it's time to put it to work on the Mystic. For too many years, the Mystic River has suffered from discharges of polluted storm water. A comprehensive strategy $* * *$ will go a long way to returning this resource to better days" (U.S. Environmental Protection Agency, 2003). On November 30, 1998, the USEPA and the Massachusetts Department of Environmental Protection (MDEP) announced a program designed to improve the quality of the water in the Mystic River Basin, including Lower Mystic Lake, Mystic River, Alewife Brook, Malden River, Island End River, Chelsea and Mill Creeks, and Boston Inner Harbor. This program is known locally as the Clean Mystic River 2010.

${ }^{1}$ U.S. Geological Survey.

${ }^{2}$ Tufts University. 


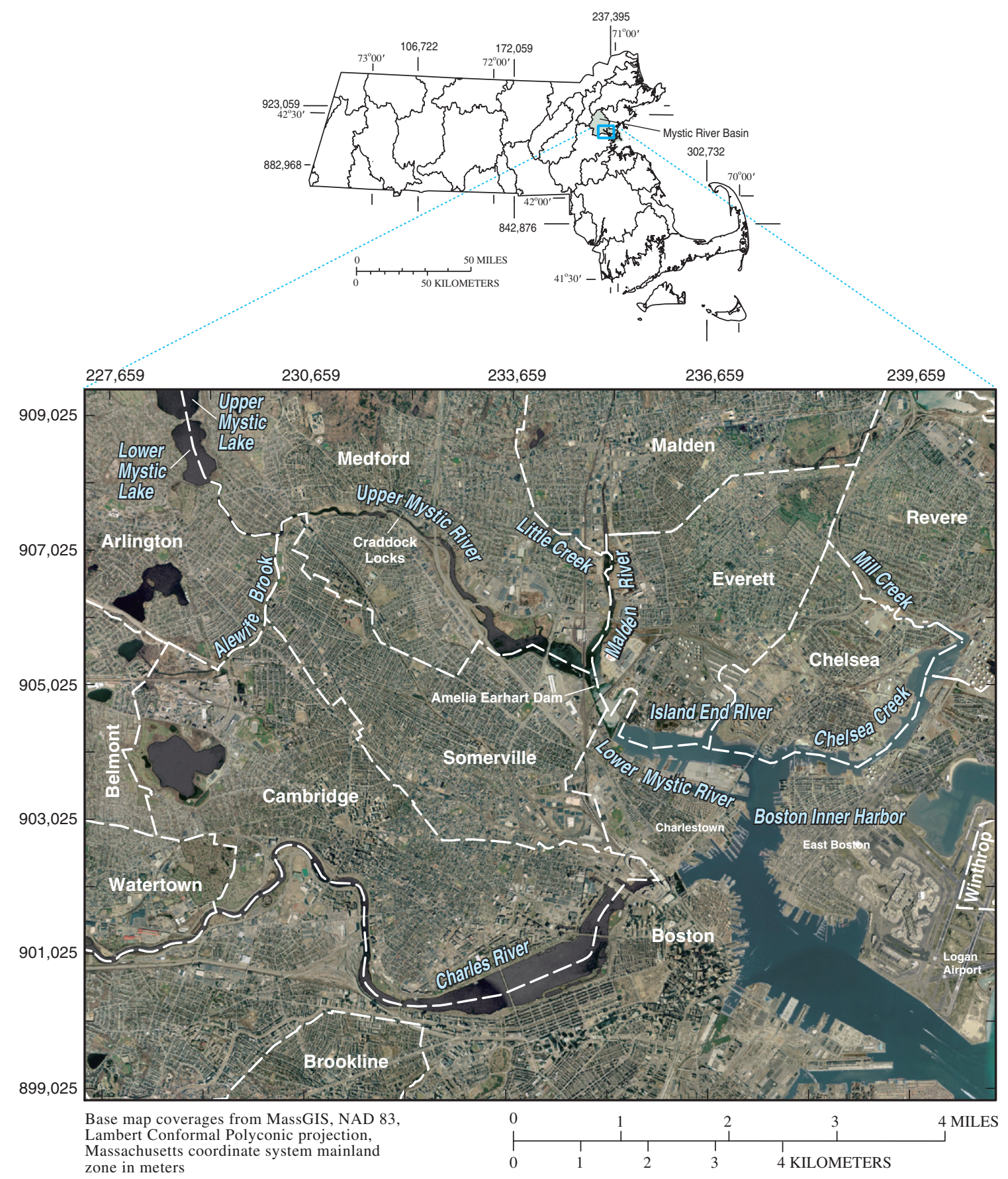

Figure 1. The location of the Mystic River Basin, Massachusetts. 


\section{Background}

New Englanders and their water resources are closely connected. As early as colonial times, New England rivers were dammed for power production, fished for food, and used for waste disposal and the transportation of goods. The rivers of the Mystic River Basin, just north of Boston, which was the leading commercial port in colonial America, were well suited for these purposes. Tidally influenced until the early 1900s, the Mystic River was the site of mills, brickyards, tanneries, and shipyards (Mystic River Watershed Association, 2004). The "Blessing of the Bay," the first ocean-going ship built in Massachusetts, was launched from the shores of the Mystic River in 1631. The waters of the Mystic River Basin also have historical importance- the first naval battle of the American Revolution took place in Chelsea Creek on May 27, 1775. In this battle, the colonists destroyed the British schooner Diana (Chelsea Historical Society, 2004).

Although many of the old factories have been replaced by housing, and rivers in the upper parts of the basin have been dammed (first by the Craddock Locks in 1909 and then by the Amelia Earhart Dam in 1966), the rivers of the Mystic River Basin are still as important economically today (2005) as they were during colonial times. Modern industries and businesses line the waterways throughout the basin. Commercial vessels (about 500 annually), such as oil tankers, bulk carriers, and container ships, deliver fuel and cargo, including gypsum, salt, cement, and scrap metal, to ports on the Mystic River and Chelsea Creek (fig. 2). Although the Mystic River Basin supports recreational activities such as kayaking, rowing, and fishing, swimming has been limited because of contamination, which has been attributed to combined-sewer overflows (CSOs) and urban runoff (Mystic River Watershed Association, 2003).

Because of the long industrial history and the subsequent urbanization of the Mystic River Basin, the Mystic River has had a long history of contamination. In 1865, the decline of fish and shellfish populations in the Mystic River was blamed, in part, on contamination (Mystic River Watershed Association, 2004). Contamination in the upper parts of the basin began as early as the late 1600s. From the mid-1800s to the mid-1900s, leather tanneries and chemical-manufacturing plants released large quantities of arsenic, chromium, lead, and other chemicals into the Aberjona River, which drains to Lower Mystic Lake, the headwaters of the Mystic
River (Wernstedt and Probst, 1997; Durant and others, 1990, Aurilio and others, 1995, Spliethoff and Hemond, 1996). Two Superfund hazardous-waste-disposal sites-wells G+H and Industri-Plex - are on the Aberjona River, the main tributary to the Mystic Lakes. In recent years, petroleum spills have contributed to the ongoing contamination of the Mystic River Basin. Since 1974 there have been over 40 recorded spills of petroleum into Chelsea Creek; moreover, it has been estimated that ground water in the area may have been contaminated with over one million gallons of oil (U.S. Environmental Protection Agency, 1999). An example of ongoing (2004) contamination in the basin can be found along the shores of the Island End River, a small tributary to the Mystic River. A major coal-gasification plant operated on the Island End River between the 1890s and the late 1950s, and residual waste from this plant continues to discharge into the river (U.S. Environmental Protection Agency, 2003b).

Urbanization has also contributed to the poor quality of the water of the Mystic River Basin. Toxic chemicals, animal waste, sediment, and trash washed from impervious areas such as roads or roof tops often end up in rivers, lakes, and estuaries. For example, 85 percent of the area of the city of Somerville is impervious (fig. 1) (Mystic River Watershed Association, 2004). Urban runoff typically contains high concentrations of bacteria, nutrients, oil and grease. Sewers are another source of contamination in the Mystic River Basin. The sewer systems in parts of the Mystic River Basin carry both sanitary discharge and stormwater, and during heavy rains these combined sewers overflow, sending raw or only marginally treated sewage into the Mystic River and its tributaries. Bacterial contamination is the reason for beach closings, shellfishing restrictions, and limitations on boating and swimming. At present, there are 17 active CSOs in the Mystic River Basin, eight of which discharge directly into Alewife Brook, a small tributary to the Mystic River (Kevin Brander, Massachusetts Department of Environmental Protection, written commun., 2004). In addition to CSOs, an aged sewer infrastructure with leaky sanitary sewers and illegal connections between sanitary sewers and storm drains also discharges sewage directly to lakes, rivers, and estuaries in the basin. The cumulative effect of this industrial history and the continuing discharge of household waste and urban runoff is that most waters in the basin fail to meet water-quality standards necessary for swimming and boating (U.S. Environmental Protection Agency, 2003a). 
A.

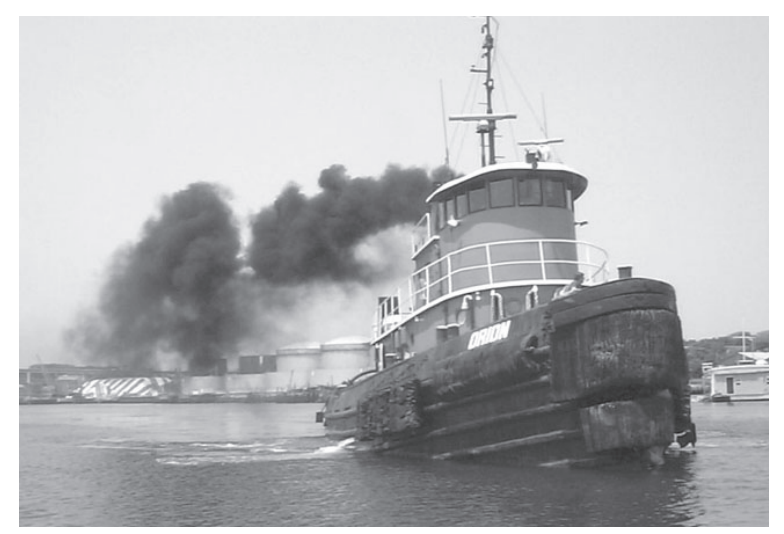

C.

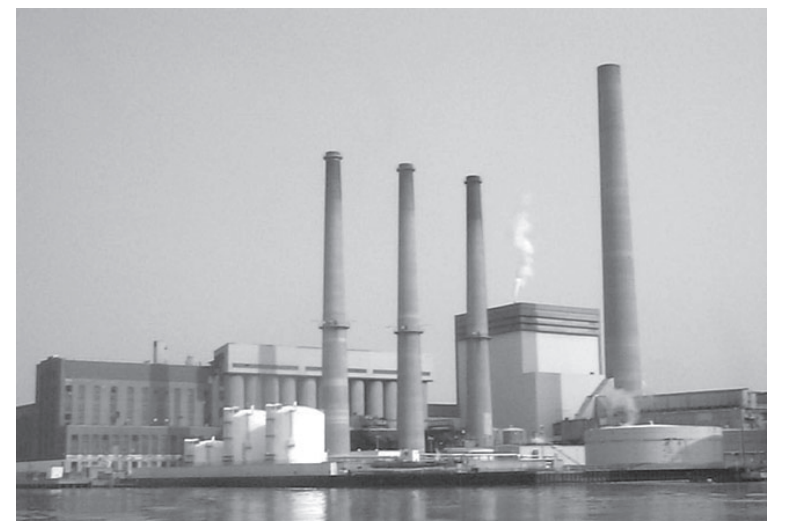

B.

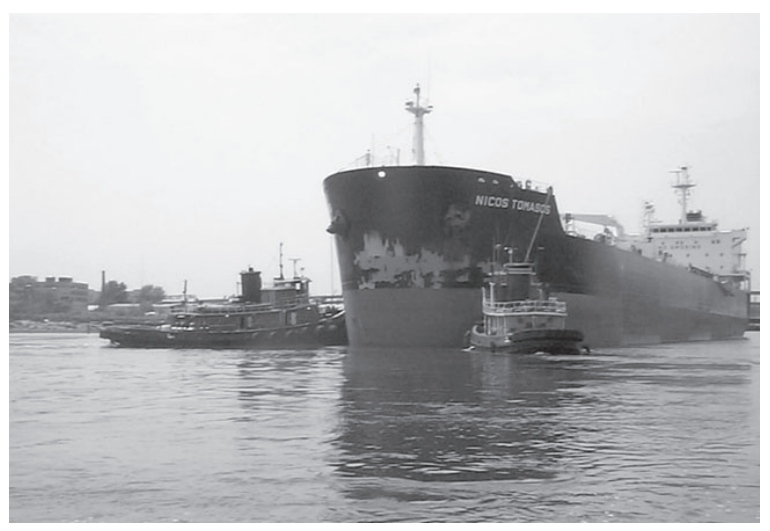

D.

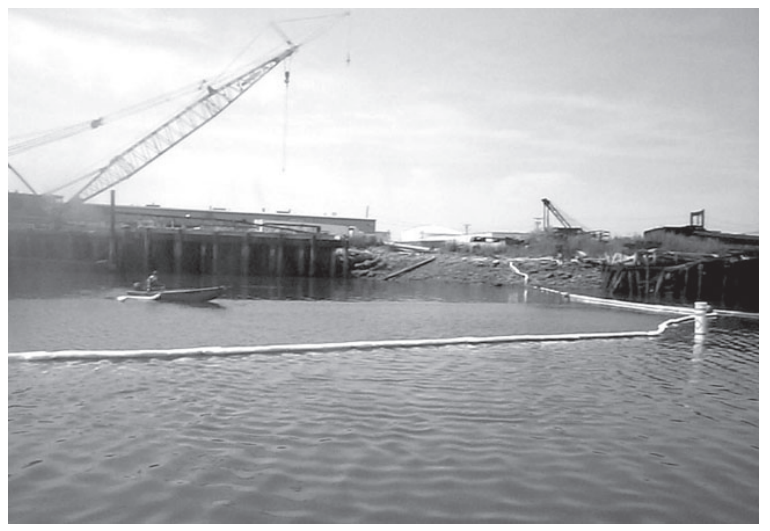

Figure 2. $A$, Tugboat operation; $B$, shipping; $C$, typical industry; and $D$, remedial action on a contaminated waterway in the lower Mystic River, Massachusetts.

Toxic chemicals, such as trace elements, and hydrophobic organic compounds (like oil) that enter natural waters often end up in the bottom sediment because their physical and chemical properties favor sorption onto sediments (Horowitz, 1991). In many rivers, high concentrations of contaminants in bottom sediment are a concern. As long as the sediments stay in the river, they remain a potential nonpoint source of contamination (de Groot, 1995). Contaminated sediments may also adversely affect benthic (bottom-dwelling) organisms (DePinto and others, 1994). In addition, chemicals in contaminated sediments may propagate through the food chain and thereby affect pelagic (swimming) organisms (Baudo and Muntau, 1990; Sly, 1994). Consumption of contaminated organisms can pose health risks to predatory fish, wildlife, and humans. Direct contact with or accidental ingestion of contaminated sediments may also pose health risks to humans (Massachusetts Department of Environmental Protection, 1996).

The distribution of toxic chemicals in sediment depends not only on the locations of contaminant sources but also on the natural processes that control sediment-particle transport. Human activities in the basin can also interfere with many of these natural processes; urbanization, dam construction, and channel alterations (dredging, channel straightening, or others) can change the sediment supply, hydraulic characteristics, or both (Montgomery and Buffington, 1998). For example, dams trap most of the sediment in impounded waters (Heinz Center, 2002), and dredging removes contaminated sediments. Both dam construction and dredging have likely altered natural sediment processes in the Mystic River Basin. 
Many agencies and organizations are involved in the ongoing cleanup efforts in the Mystic River Basin, including the MDEP, the Massachusetts Department of Conservation and Recreation (DCR), the Massachusetts Water Resources Authority (MWRA), the Mystic River Watershed Association (MyRWA), the Chelsea Creek Action Group (CCAG), the Friends of Alewife Reservation, the USEPA, the Massachusetts Institute of Technology (MIT), Tufts University, and others. With the support of these Federal, State, and local institutions, the USGS was asked to undertake this cooperative study of sediment quality in the Mystic River Basin in 2001.

\section{Purpose and Scope}

This report describes the collection of 104 sediment grab samples (from the top 2-4 in. of sediment) and 8 sediment core samples and presents maps of bathymetry and sediment thickness in the Mystic River Basin. This report also describes the occurrence and geographic distribution of contaminantsinorganic elements, PAHs, pesticides, and PCBs - in bottom sediment. Trends in the depositional history of contaminants to lakes, rivers, and estuaries in the Mystic River Basin area are also described. Finally, the report discusses the potential adverse effects that these contaminants may have on aquatic organisms and humans.

\section{Previous Studies}

Several studies have been done in the Mystic River Basin to characterize sediment and water-quality problems. The USEPA, in cooperation with Nangle Consulting Associates, completed a study of sediment and water quality of the Malden River (Nangle Consulting Associates, 2000). Water samples were analyzed for total dissolved solids, total suspended solids, and nitrates; water-quality properties measured included alkalinity, conductivity, dissolved oxygen, $\mathrm{pH}$, and temperature. Sediment samples were analyzed for trace elements, PAHs, and volatile organic compounds. Sediment samples collected in that study showed high concentrations of the trace elements and several individual PAHs, particularly at the confluence of Little Creek and the Malden River (Nangle Consulting Associates, 2000). The Massachusetts Institute of Technology (MIT), Tufts University, the U.S. Army Corps of Engineers (USACE), and the USEPA have studied sediment and water quality in Upper Mystic Lake and its major tributary, the Aberjona River, which flows through two Superfund sites. These studies focused primarily on arsenic contamination in the upper parts of the Mystic River Basin (Aurilio and others, 1993; Aurilio and others, 1995); however, the distribution of other toxic elements has also been described (Knox, 1991).

Studies of sediment quality have also been done in the tidal parts of the basin, including the lower Mystic River (downstream of the Amelia Earhart Dam), Island End River, Chelsea Creek, and the Inner Harbor. The USGS has assembled a database that contains sediment-quality data from more than 3,000 sediment samples in the tidal parts of the Mystic River Basin (Buchholtz ten Brink and others, 2002). Concentrations of trace elements such as copper, lead, mercury, and zinc were greater than their respective toxicitycriteria concentrations in nearly one-half of the samples, and ranged from 4 to more than 20 times their respective background concentrations. Organic compounds were also detected in high concentrations at many sampling locations (Manheim and others, 1999).

\section{Sample Collection Methods and Analysis}

Water depths were measured upstream of the Amelia Earhart Dam in the upper Mystic River (upstream of the Amelia Earhart Dam), the Malden River, Alewife Brook, and Lower Mystic Lake. Sediment-thickness data were also collected upstream of the dam. No sediment-thickness data were collected in the Lower Mystic Lake because the water was too deep for the methods used in this study. Sediment grab samples were collected randomly throughout the study area (table 1; fig. 3). Sediment cores were collected at eight locations (table 1; fig. 3). All sediment samples (grabs and cores) were analyzed for selected toxic elements and organic compounds.

\section{Water Depths and Sediment Thickness}

Water depths were measured on September 17-19, October 30, and December 2-4, 2001. On these days, the water altitudes measured on the upstream side of the Amelia Earhart Dam ranged from 105.2 to $105.8 \mathrm{ft}$ (relative to Massachusetts District Commission (MDC) Datum). Water depths, however, were adjusted to a datum of $105.8 \mathrm{ft}$ by adding the height of the water measured at each site to the difference between $105.8 \mathrm{ft}$ and the altitude measured at the dam at the time of sampling. 
Table 1. Bottom-sediment sampling sites in the Mystic River Basin, Massachusetts.

[Latitude and longitude: In degrees, minutes, and seconds. No., number; USGS, U.S. Geological Survey; do, ditto]

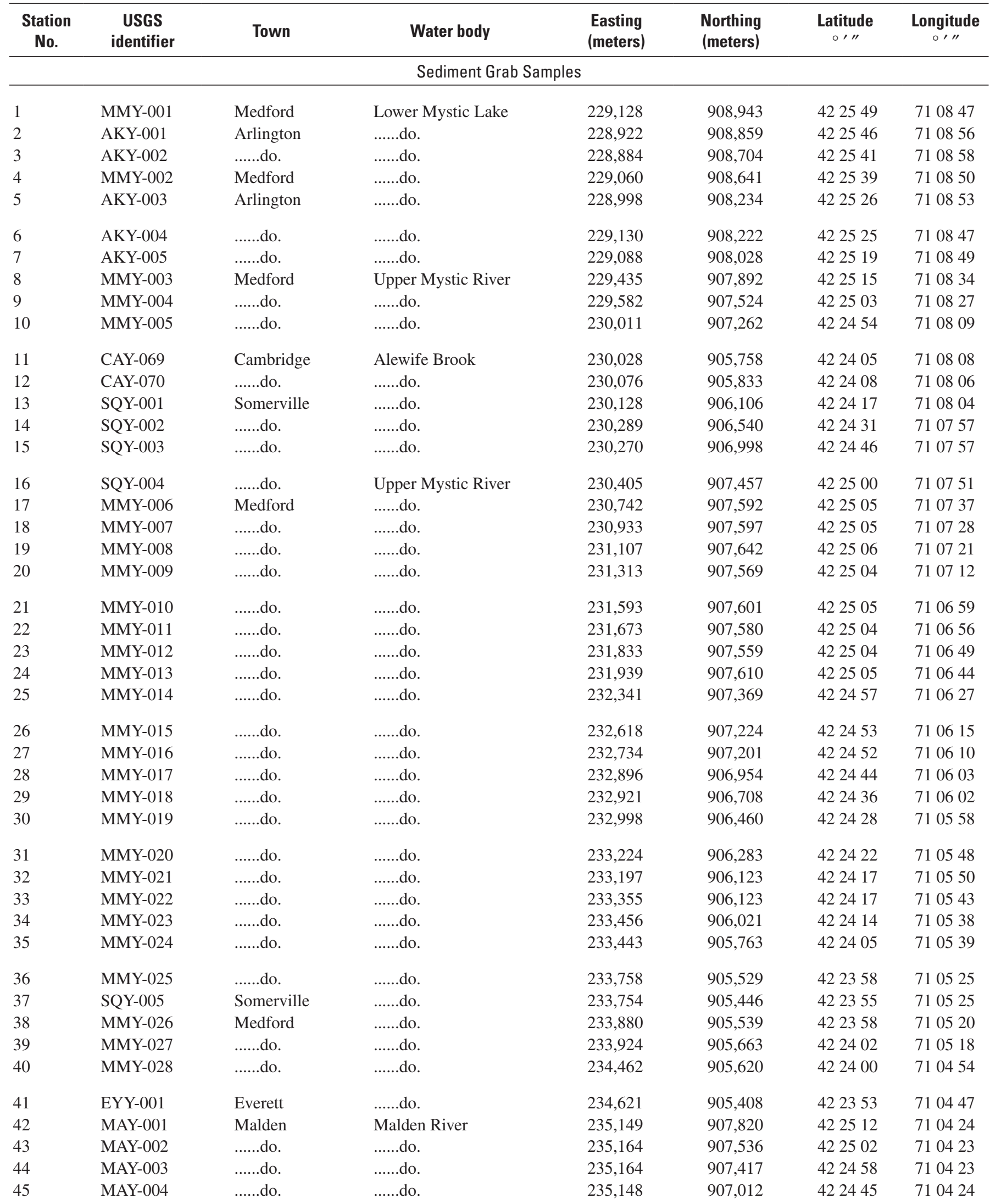


Table 1. Bottom-sediment sampling sites in the Mystic River Basin, Massachusetts.-Continued

[Latitude and longitude: In degrees, minutes, and seconds. No., number; USGS, U.S. Geological Survey; do, ditto]

\begin{tabular}{|c|c|c|c|c|c|c|c|}
\hline $\begin{array}{c}\text { Station } \\
\text { No. }\end{array}$ & $\begin{array}{c}\text { USGS } \\
\text { identifier }\end{array}$ & Town & Water body & $\begin{array}{c}\text { Easting } \\
\text { (meters) }\end{array}$ & $\begin{array}{l}\text { Northing } \\
\text { (meters) }\end{array}$ & $\begin{array}{c}\text { Latitude } \\
{ }^{\prime} \prime \prime\end{array}$ & \begin{tabular}{c} 
Longitude \\
\hdashline,$\prime \prime$
\end{tabular} \\
\hline \multicolumn{8}{|c|}{ Sediment Grab Samples_Continued } \\
\hline 46 & EYY-002 & Everett & Malden River & 235,243 & 906,782 & 422438 & 710420 \\
\hline 47 & EYY-003 & .......do. & ......do. & 235,170 & 906,662 & 422434 & 710423 \\
\hline 48 & EYY-004 & ......do. & ......do. & 235,300 & 906,216 & 422420 & 710418 \\
\hline 51 & EYY-007 & ......do. & ......do. & 235,023 & 905,444 & 422355 & 710430 \\
\hline 52 & EYY-008 & ......do. & ......do. & 234,891 & 905,396 & 422353 & 710436 \\
\hline 53 & EYY-009 & ......do. & Upper Mystic River & 234,942 & 905,217 & 422347 & 710433 \\
\hline 54 & EYY-010 & ......do. & ......do. & 235,112 & 905,136 & 422345 & 710426 \\
\hline 55 & SQY-006 & Somerville & Lower Mystic River & 234,968 & 904,960 & 422339 & 710432 \\
\hline 59 & BGY-140 & ......do. & .......do. & 235,444 & 904,796 & 422333 & 710412 \\
\hline 60 & BGY-141 & .......do. & .......do. & 235,318 & 904,448 & 422322 & 710417 \\
\hline 61 & BGY-142 & ......do. & ......do. & 235,467 & 904,172 & 422313 & 710411 \\
\hline 62 & EYY-013 & Everett & .......do. & 235,916 & 904,255 & 422316 & 710351 \\
\hline 63 & BGY-143 & Boston & ......do. & 236,015 & 903,860 & 422303 & 710347 \\
\hline 64 & EYY-014 & Everett & .......do. & 236,105 & 904,125 & 422312 & 710343 \\
\hline 65 & EYY-015 & .......do. & .......do. & 236,191 & 904,321 & 422318 & 710339 \\
\hline 66 & BGY-144 & Boston & .......do. & 236,240 & 903,899 & 422304 & 710337 \\
\hline 67 & EYY-016 & Everett & ......do. & 236,306 & 904,131 & 422312 & 710334 \\
\hline 75 & BGY-146 & Boston & Lower Mystic River & 236,882 & 903,938 & 422305 & 710309 \\
\hline 76 & BGY-147 & ......do. & .......do. & 237,157 & 903,853 & 422303 & 710257 \\
\hline 77 & CIY-002 & Chelsea & .......do. & 237,220 & 904,184 & 422313 & 710254 \\
\hline 78 & CIY-003 & ......do. & .......do. & 237,285 & 904,091 & 422310 & 710251 \\
\hline 79 & CIY-004 & ......do. & ......do. & 237,465 & 903,904 & 422304 & 710243 \\
\hline 80 & CIY-005 & .......do. & Mill Creek & 240,376 & 905,760 & 422404 & 710036 \\
\hline 81 & RDY-001 & Revere & Chelsea Creek & 240,408 & 905,606 & 422359 & 710034 \\
\hline 82 & RDY-002 & ......do. & ......do. & 240,365 & 905,501 & 422355 & 710036 \\
\hline 83 & CIY-006 & Chelsea & .......do. & 239,900 & 905,415 & 422353 & 710057 \\
\hline 84 & CIY-007 & ......do. & .......do. & 239,922 & 905,276 & 422348 & 710056 \\
\hline 85 & CIY-008 & .......do. & .......do. & 239,824 & 905,096 & 422342 & 710100 \\
\hline 86 & BGY-148 & Boston & .......do. & 239,858 & 904,915 & 422337 & 710059 \\
\hline 87 & CIY-009 & Chelsea & .......do. & 239,667 & 904,543 & 422325 & 710107 \\
\hline 88 & CIY-010 & ......do. & .......do. & 239,575 & 904,361 & 422319 & 710111 \\
\hline 89 & BGY-149 & Boston & .......do. & 239,504 & 904,195 & 422313 & 710114 \\
\hline 90 & BGY-150 & .......do. & .......do. & 239,296 & 904,022 & 422308 & 710123 \\
\hline
\end{tabular}


Table 1. Bottom-sediment sampling sites in the Mystic River Basin, Massachusetts._- Continued

[Latitude and longitude: In degrees, minutes, and seconds. No., number; USGS, U.S. Geological Survey; do, ditto]

\begin{tabular}{|c|c|c|c|c|c|c|c|}
\hline $\begin{array}{c}\text { Station } \\
\text { No. }\end{array}$ & $\begin{array}{c}\text { USGS } \\
\text { identifier }\end{array}$ & Town & Water body & $\begin{array}{c}\text { Easting } \\
\text { (meters) }\end{array}$ & $\begin{array}{l}\text { Northing } \\
\text { (meters) }\end{array}$ & $\begin{array}{c}\text { Latitude } \\
0_{\prime \prime \prime \prime}\end{array}$ & $\begin{array}{c}\text { Longitude } \\
0^{\prime \prime \prime \prime}\end{array}$ \\
\hline \multicolumn{8}{|c|}{ Sediment Grab Samples_-Continued } \\
\hline 91 & BGY-151 & Boston & Chelsea Creek & 239,021 & 903,858 & 422302 & 710135 \\
\hline 92 & CIY-011 & Chelsea & ......do. & 238,826 & 903,873 & 422303 & 710144 \\
\hline 93 & CIY-012 & ......do. & .......do. & 238,677 & 903,971 & 422306 & 710150 \\
\hline 96 & CIY-014 & ......do. & .......do. & 238,234 & 903,992 & 422307 & 710210 \\
\hline 97 & CIY-015 & ......do. & ......do. & 238,030 & 904,086 & 422310 & 710219 \\
\hline 98 & BGY-153 & Boston & ......do. & 237,961 & 903,959 & 422306 & 710222 \\
\hline 99 & CIY-016 & Chelsea & ......do. & 237,945 & 904,174 & 422313 & 710222 \\
\hline 100 & CIY-017 & ......do. & ......do. & 237,807 & 904,045 & 422309 & 710228 \\
\hline 104 & BGY-157 & ......do. & ......do. & 237,543 & 903,456 & 422250 & 710240 \\
\hline \multicolumn{8}{|c|}{ Sediment Core Samples } \\
\hline 105 & AKY-006 & Arlington & Lower Mystic Lake & 236,848 & 904,464 & 422326 & 710310 \\
\hline 106 & MMY-029 & Medford & Upper Mystic River & 229,161 & 908,193 & 422525 & 710846 \\
\hline 107 & MMY-030 & .......do. & Malden River & 235,199 & 906,338 & 422444 & 710422 \\
\hline 108 & MMY-031 & ......do. & Upper Mystic River & 234,965 & 904,455 & 422345 & 710433 \\
\hline 109 & MAY-005 & Malden & ......do. & 235,059 & 904,455 & 422345 & 710428 \\
\hline 110 & SQY-007 & Somerville & Lower Mystic River & 234,086 & 906,333 & 422401 & 710511 \\
\hline 111 & BGY-158 & Boston & ......do. & 235,197 & 904,456 & 422326 & 710422 \\
\hline
\end{tabular}




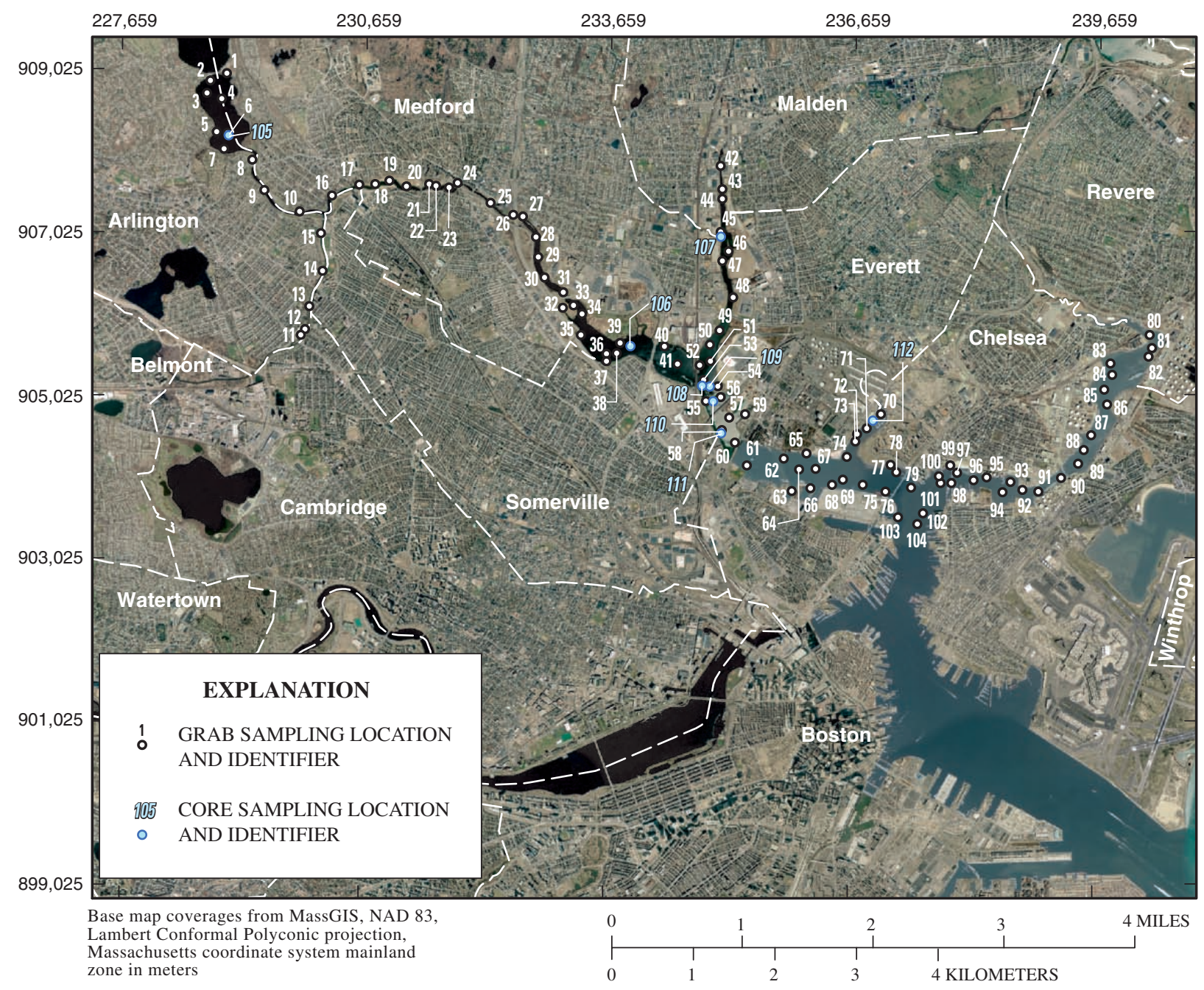

Figure 3. Sediment grab and core sampling locations, Mystic River Basin, Massachusetts. 
An echo sounder was used to measure water depths. Water-depth data were recorded simultaneously with positional data taken with a handheld global-positioning-system (GPS) receiver. A steel rod, manually pushed into the bottom sediment, was used to collect soft-sediment-thickness data. Sediment-thickness measurements were made at more than 300 locations. A combination of the triangular irregular network (TIN) data model and topogrid functions of ESRI's ARC/INFO geographic information systems (GIS) software (Environmental Research Institute, Inc., Version 8.02) was used to map channel morphology and bottom-sediment thickness from water-depth and sediment-thickness data (fig. 4).

\section{Sample-Collection Design}

Grab samples were collected from 104 locations upstream of the Amelia Earhart Dam in October 2001 and downstream of the dam in June 2003 (table 1; fig. 3). A subroutine within ARC/INFO GIS software (Scott, 1990) was used to select the sampling locations randomly. A GPS unit was used to navigate to these locations in the study area. In addition, eight core samples were collected in December 2001 and July 2003 (table 1; fig. 3). These samples were collected in areas of deposition of fine-grained sediment.

\section{Sample-Collection Techniques}

A stainless-steel Eckman dredge was used to collect grab samples (fig. 5). A minimum of three samples was collected at each sampling location to characterize conditions at the site (Baudo and Mantau, 1990). Any water trapped in the dredge was decanted off after most of the fines had settled. The top 2-4 in. of the sample was removed from the dredge, placed in a precleaned stainless-steel bowl, and homogenized with a stainless-steel spatula in the field. Exceptions were the grab samples collected downstream of the Amelia Earhart Dam; these samples were placed in precleaned disposable Teflon bags and homogenized with a Teflon spoon. Each sample was divided into subsamples, which were placed in precleaned containers and stored on ice for overnight delivery to the appropriate laboratory.

Teflon bags were precleaned by rinsing with methanol, 5-percent hydrochloric acid $(\mathrm{HCl})$, and deionized water, in that order. In the field, all sediment-sampling equipment was cleaned between samplings by scrubbing with a nylon brush and phosphate-free detergent, and rinsing with methanol, deionized water, and finally, native water from the sampling sites. After the methanol rinse, the Teflon spoon received an additional rinse with 5-percent $\mathrm{HCl}$.
A freeze corer was used to collect sediment cores (fig. 6). The core barrel was filled with a dry ice and methanol slurry and allowed to fall freely through the water column into the sediment. The core was retrieved after about 20 minutes, wrapped in plastic, labeled, and transported on dry ice to Tufts University in Medford, MA. Individual subsamples were sliced from the core with a hot tungsten wire and placed in precleaned containers.

\section{Chemical Analysis}

Sediment samples were analyzed for a suite of inorganic elements and organic compounds commonly found in rivers that drain industrial and urban watersheds (table 2).

XRAL Laboratory of Ontario, Canada, analyzed the sediment samples for inorganic elements by inductively coupled plasma atomic emission spectroscopy. Researchers at Tufts University analyzed sediment samples for a suite of organic compounds, including PAHs, organochlorine pesticides, and PCBs, by gas chromatography with mass spectrometry.

\section{Data-Analysis Methods}

A variety of statistical methods was used to summarize sediment-quality data. Particular attention was given to censored data, defined as measured concentrations that were less than the detection limit. For example, total concentrations $(\Sigma)$ of PAHs, PCBs, and organochlorine pesticides were calculated by adding individual constituent concentrations. If individual concentrations were below detection limits, concentrations of those constituents were set to zero. If all of the individual constituents of a group such as PAHs were below detection limits, then the detection limits were added and the total PAH concentration was estimated to be less than the sum of the detection limits.

The USGS's Method Detection Limit (MDL) function of the S-Plus statistical software package was used to calculate summary statistics for constituents with censored data. A minimum of three observations is required to determine summary statistics by means of the MDL function, which uses a log-probability method (Helsel and Cohn, 1998). If the MDL program was not appropriate (for example, if there were fewer than three observations), simple population statistics were calculated with Microsoft Excel by setting censored data equal to one-half the reported detection limit. This procedure was used only for the cadmium statistics for Boston Inner Harbor. 


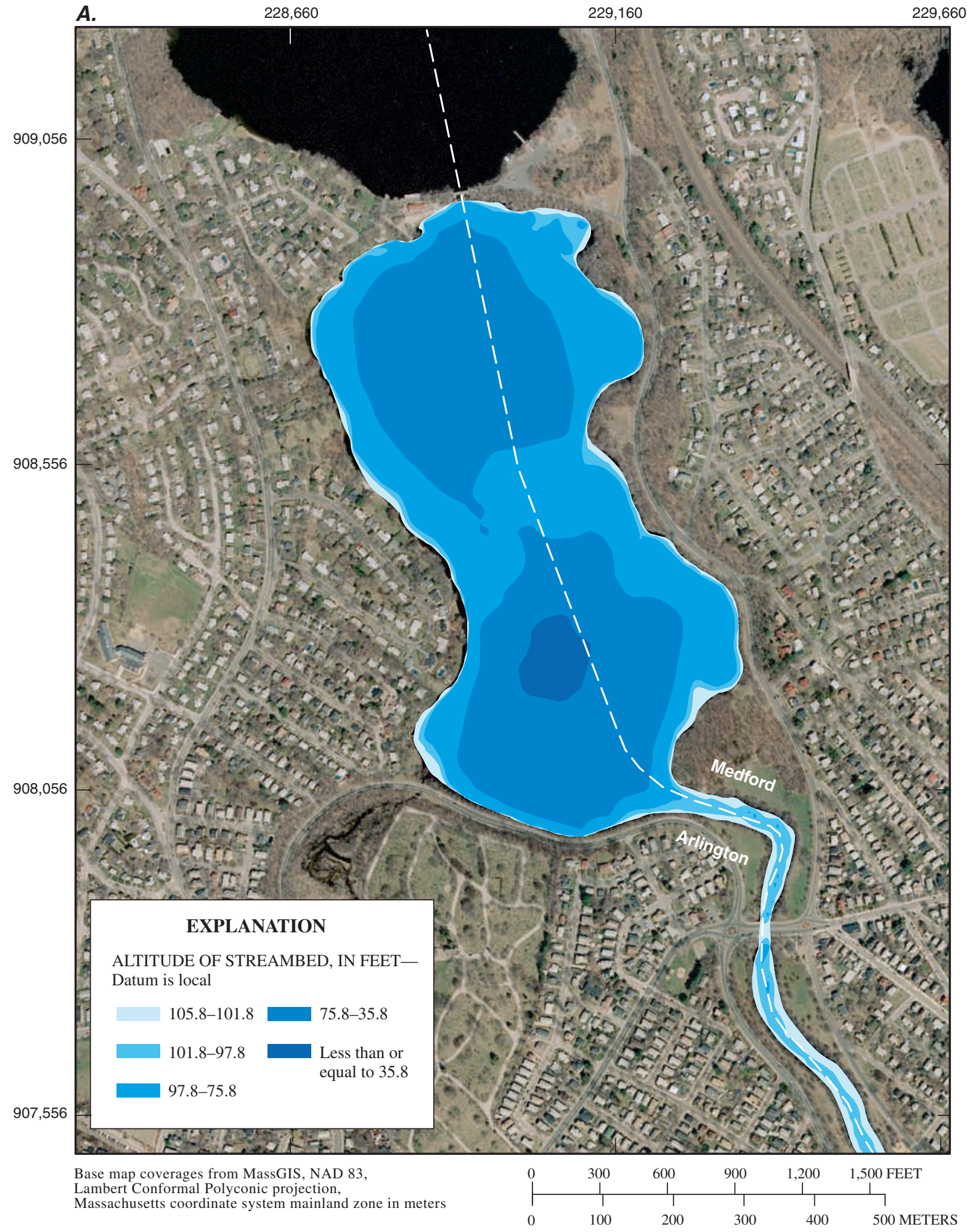

Figure 4. Altitude of streambed, sediment thickness, or both in the Mystic River Basin, Massachusetts: $A$, Lower Mystic Lake; $B$, Alewife Brook and its confluence with the upper Mystic River; and $C$, upper Mystic River and the Malden River above the Amelia Earhart Dam. 


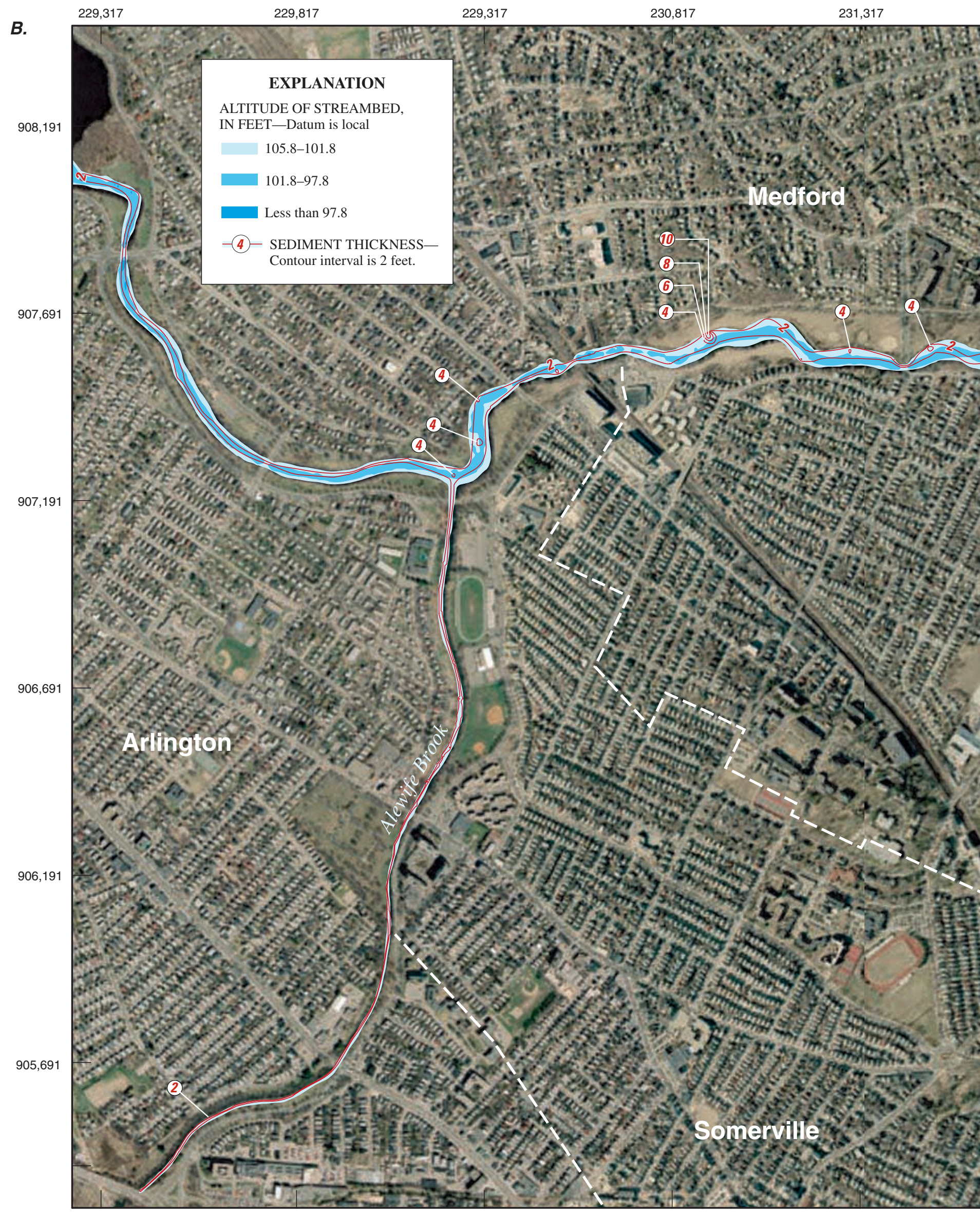


231,817

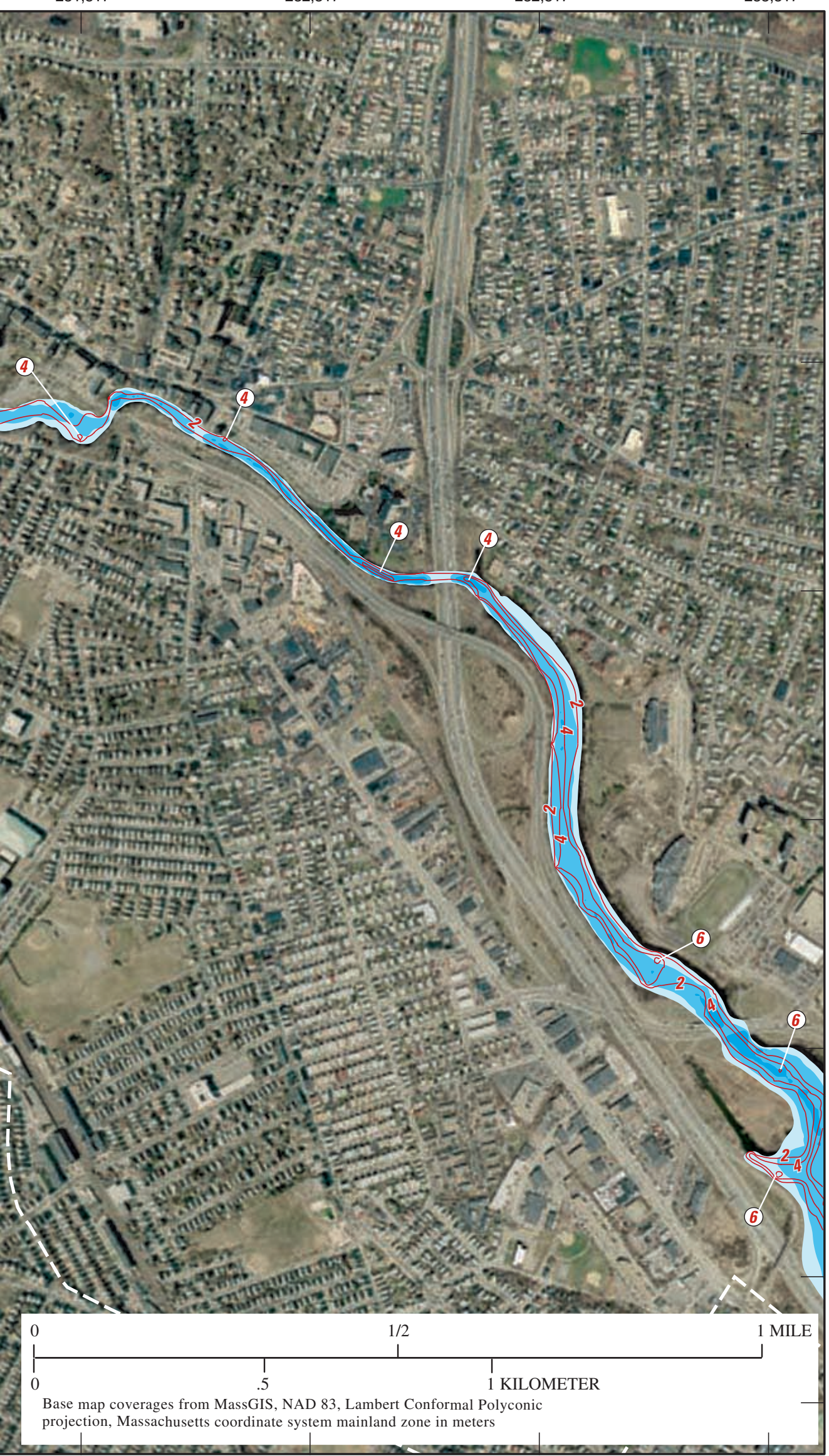

Figure 4-Continued. Altitude of streambed, sediment thickness, or both in the Mystic River Basin, Massachusetts: $A$, Lower Mystic Lake; $B$, Alewife Brook and its confluence with the upper Mystic River; and $C$, upper Mystic River and the Malden River above the Amelia Earhart Dam. 


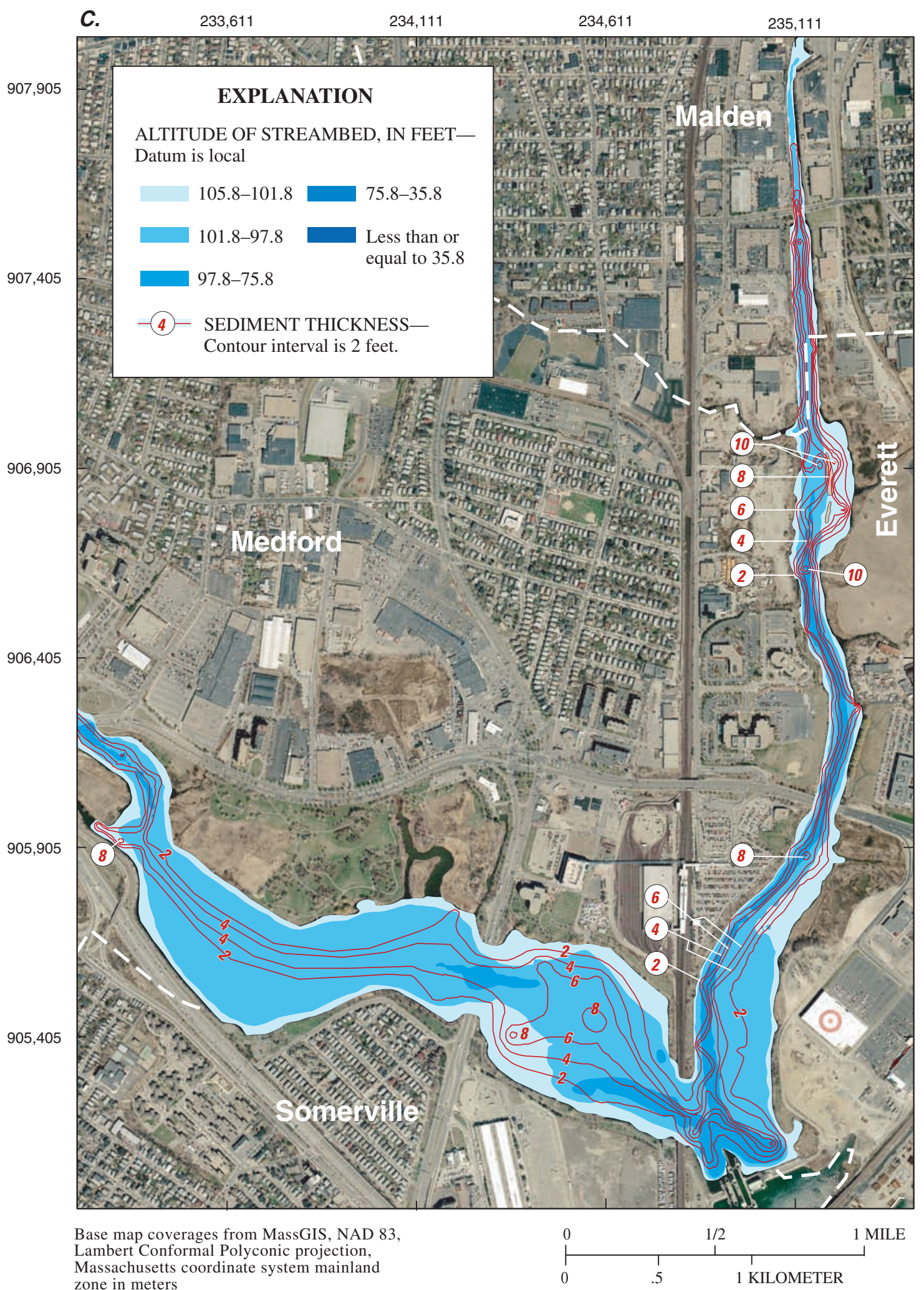

Figure 4-Continued. Altitude of streambed, sediment thickness, or both in the Mystic River Basin, Massachusetts: A, Lower Mystic Lake; $B$, Alewife Brook and its confluence with the upper Mystic River; and $C$, upper Mystic River and the Malden River above the Amelia Earhart Dam. 
A.

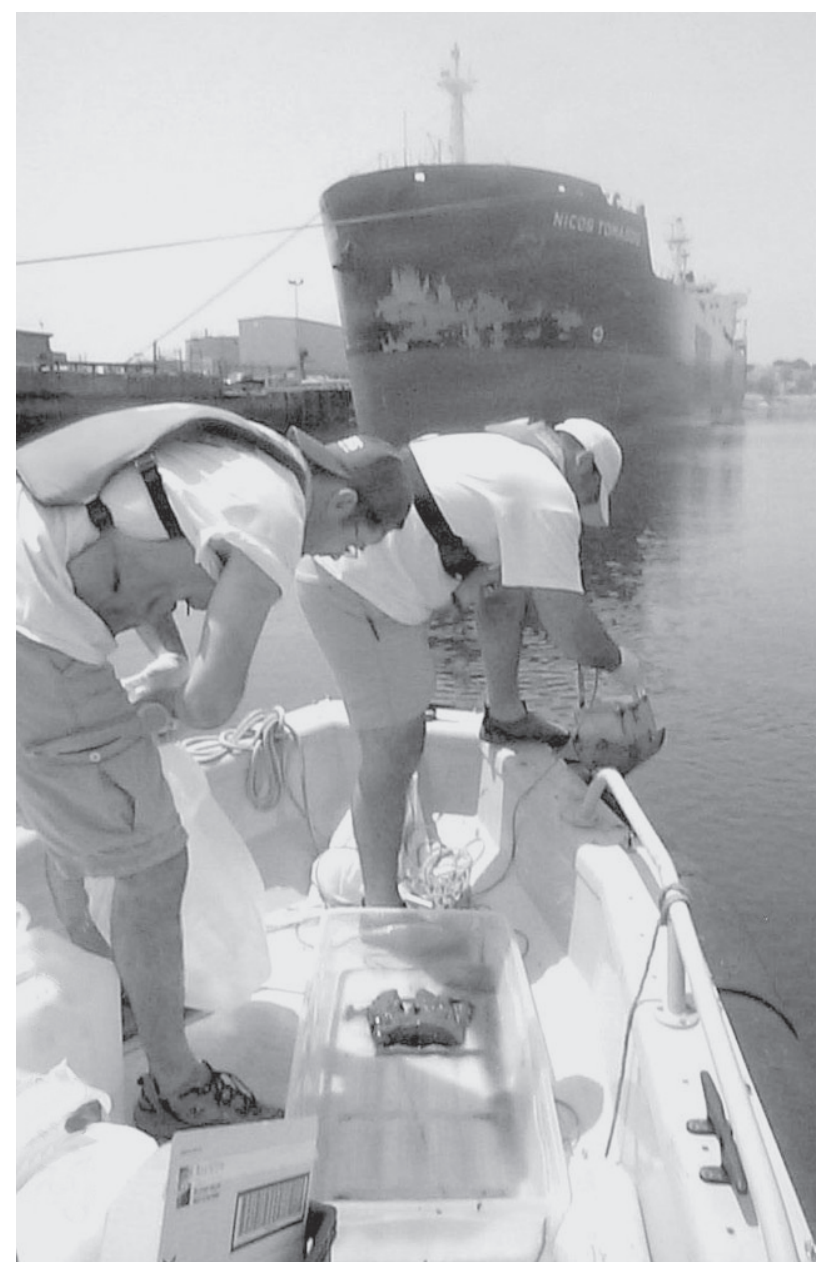

B.

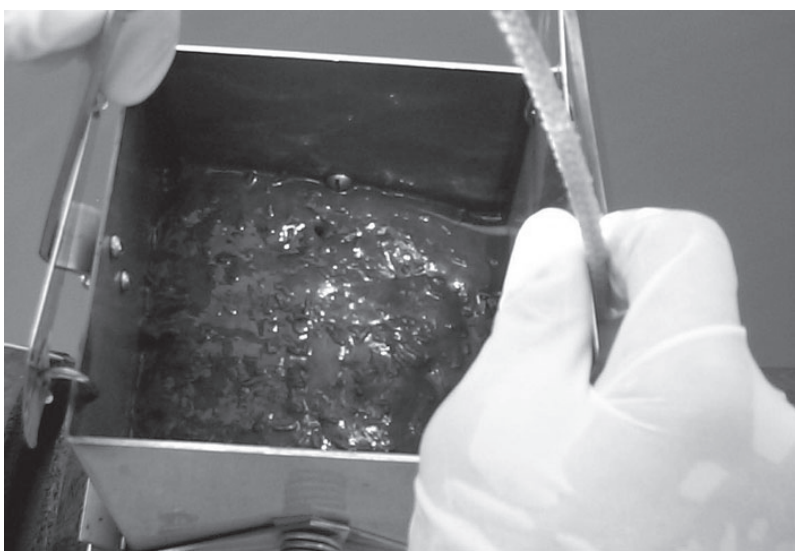

C.

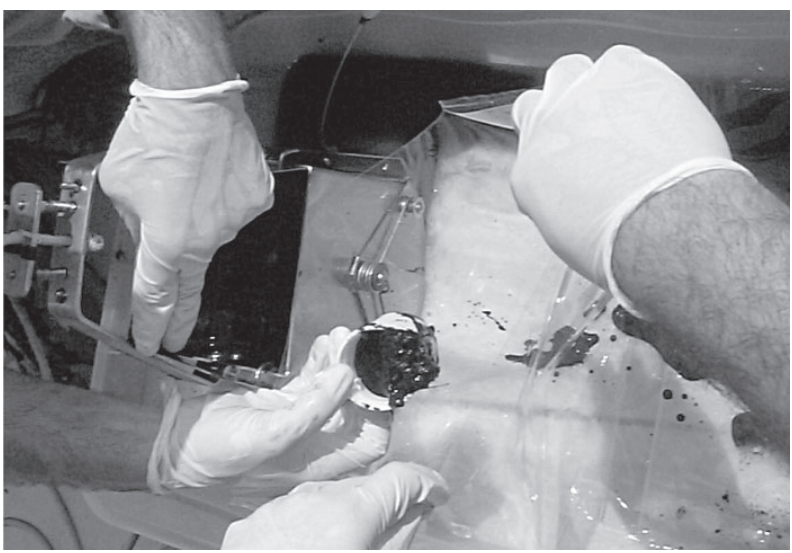

$D$.

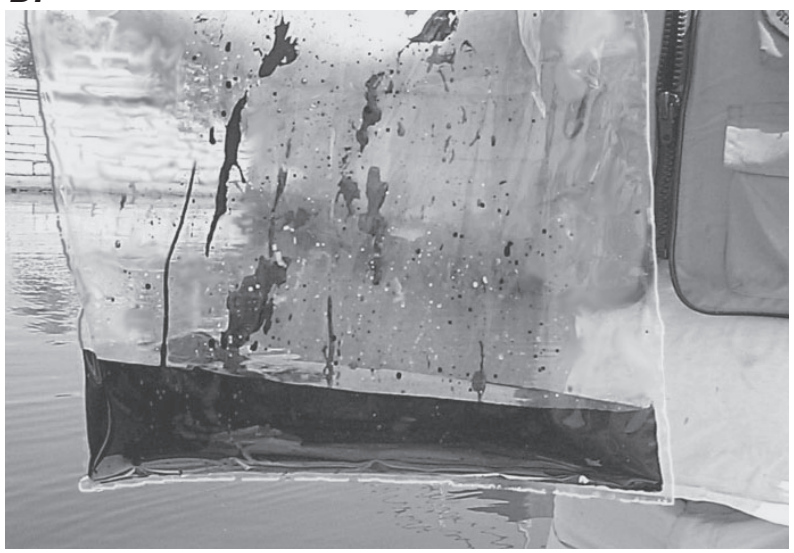

Figure 5. A, U.S. Geological Survey personnel collecting a sediment grab sample; $B$, sediment collected in the dredge; $C$, transfer of sediment sample from the dredge into a Teflon bag; and $D$, a waterlogged sediment sample collected from the lower Mystic River, Massachusetts. 
A.

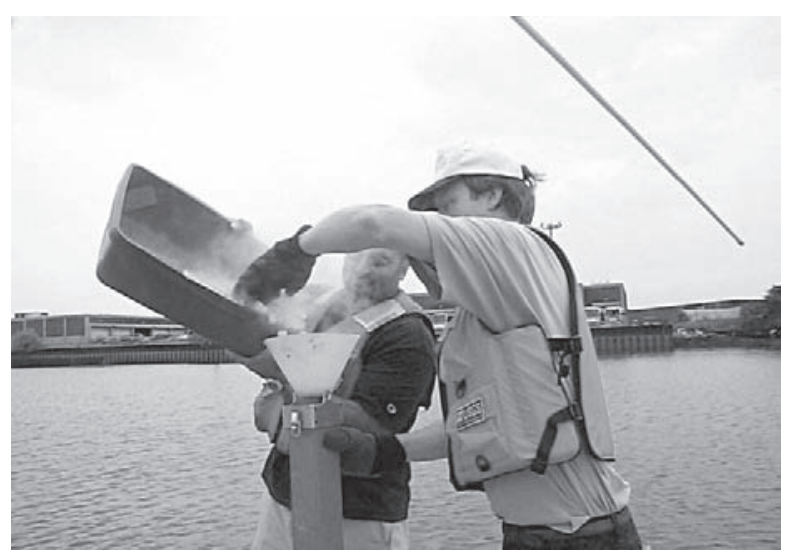

C.

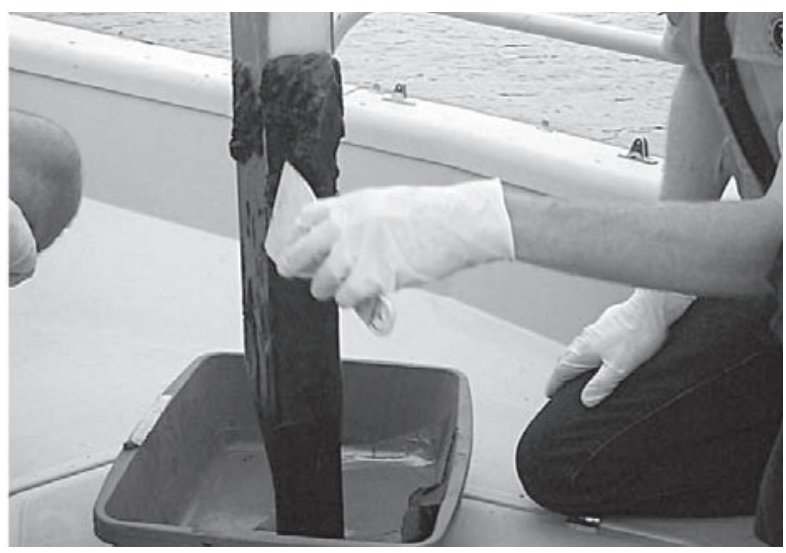

B.

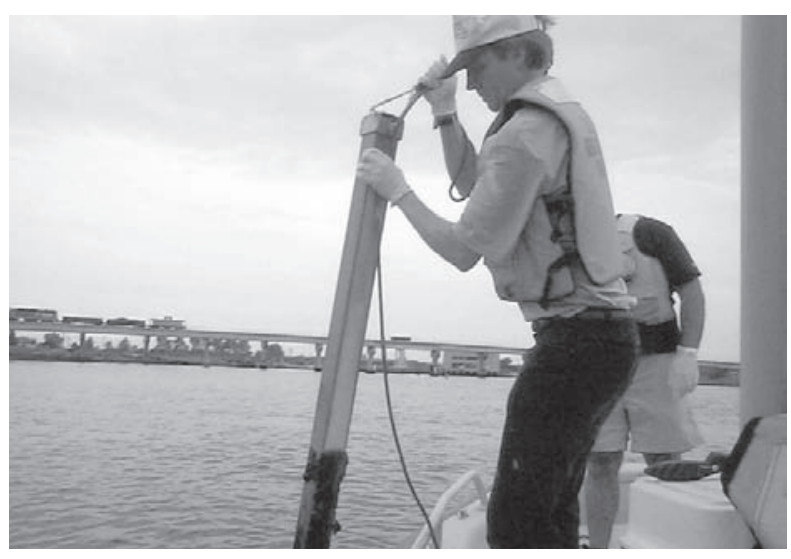

$D$.

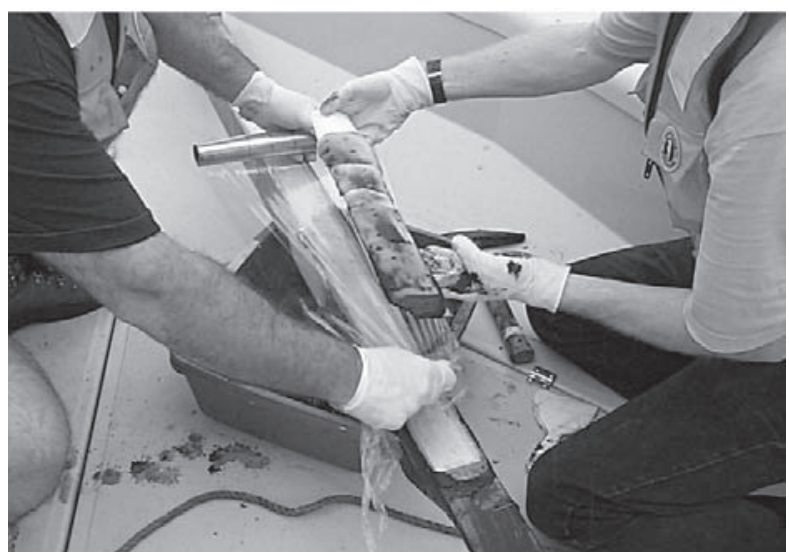

Figure 6. $A$, Dry ice being placed into freeze corer; $B$, retrieval of freeze corer; $C$, removal of excess sediment from corer; and $D$, sediment-core preservation by wrapping the core in plastic.

\section{Bias and Variability}

Sediment-quality data are subject to bias (or systematic error) and variability (or random error) during sample collection, processing, and analysis. The nature and magnitude of bias and variability can be determined by analysis of qualitycontrol samples, including blanks, field duplicates, laboratory duplicates, matrix spikes, matrix-spike duplicates, and performance-evaluation samples (PES) (these data can be found in tables 3-5, at back of report). With a few exceptions, bias and variability in this study were generally within acceptable limits. Most notable is the potential contamination bias introduced by the equipment used for collection and processing of some grab samples (stainless-steel dredge, bowl, and spoon). The analysis of PES samples mixed in the stainless steel bowl indicates that grab samples may have been enriched in chromium from sampling or processing equipment (table 3). As a result of these findings, the standard operating procedure (SOP) for sediment sampling was changed. A Teflon spoon was used instead of a stainless-steel spoon to scoop material that had not come in contact with any part of the dredge and to composite the samples in disposable precleaned Teflon bags instead of in the stainless steel bowl. Therefore, chromium values measured in sediment samples processed with the stainless steel bowl and spoon were not included in this report. 
Table 2. Constituents analyzed in sediment samples from the Mystic River Basin, Massachusetts, and their common sources and uses.

[BHC, 1,2,3,4,5,6-hexachlorocyclohexane; DDD, dichlorodiphenyldichloroethane; DDE, dichlorodiphenyldichloroethylene; DDT, dichlorodiphenyltrichloroethane; PCBs, polychlorinated biphenyls; do., ditto]

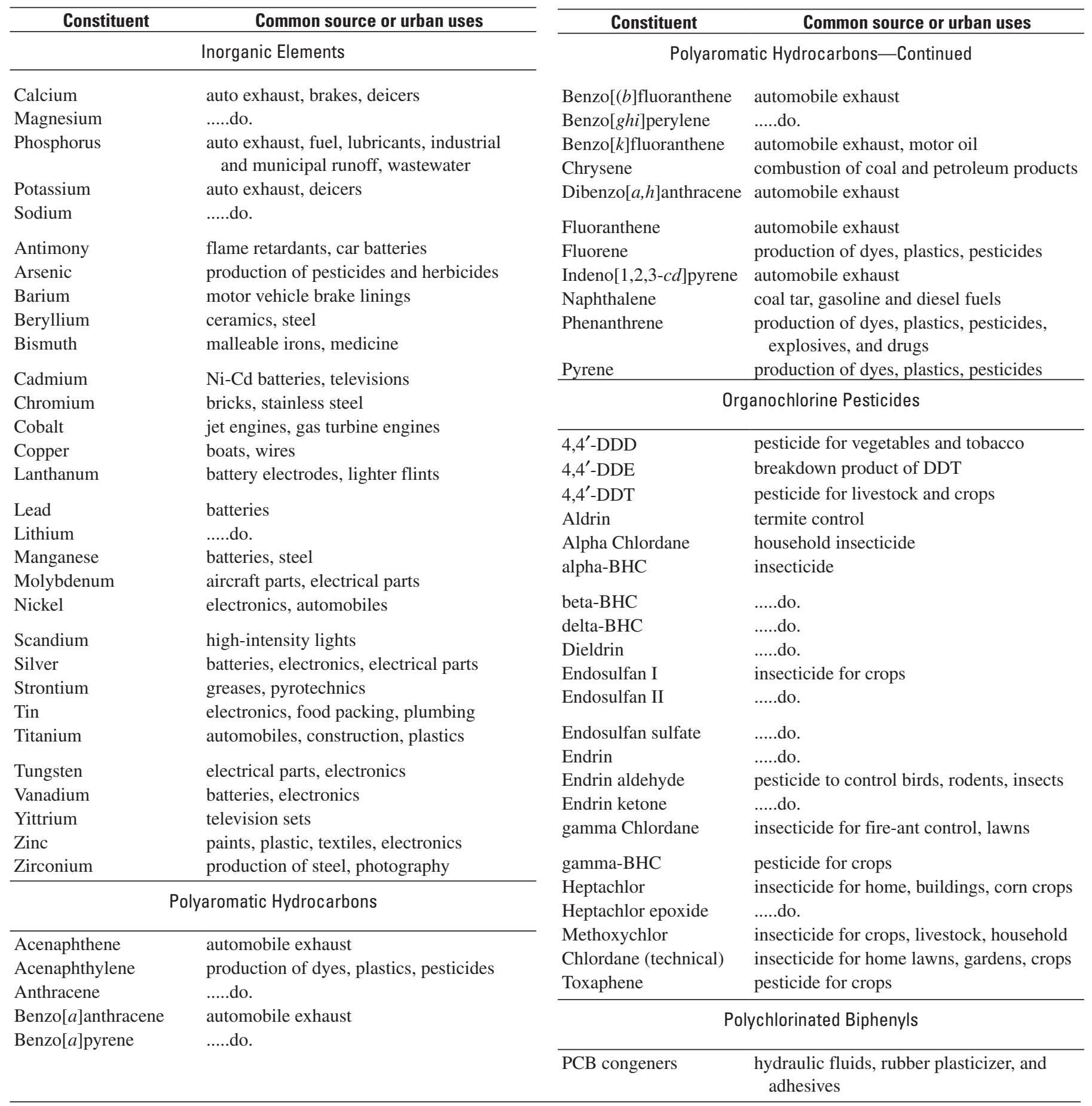




\section{Water Depths and Sediment Thickness}

The channel morphology in figures $4 A-C$ shows that when water levels at the Amelia Earhart Dam are at $105.8 \mathrm{ft}$ relative to MDC's datum, water depths measured in Lower Mystic Lake upstream of the dam ranged from less than $1 \mathrm{ft}$ to almost $80 \mathrm{ft}$. Water depths were greatest in the lake and averaged over $33 \mathrm{ft}$ (fig. 4A). In contrast, the average water depth was lowest in Alewife Brook (only about $1 \mathrm{ft}$; fig. 4B). Water depths measured in the upper Mystic and Malden Rivers averaged about 5 and $6 \mathrm{ft}$, respectively (figs. $4 B-C$ ). Based on measurements of water depth, the estimated volumes of water in the Lower Mystic Lake, Alewife Brook, and upper Mystic and Malden Rivers are about 1,000, 2,300, and $150 \mathrm{Mgal}$, respectively.

Soft-sediment thicknesses are also shown in figures $4 B-C$. Sediment thicknesses ranged from less than $1 \mathrm{ft}$ to about $13 \mathrm{ft}$ near the dam. Sediment thicknesses measured in Alewife Book and the upper Mystic and Malden Rivers were about 2, 3, and $4 \mathrm{ft}$, respectively. Based on measurements of soft-sediment thickness, the estimated sediment volume in Alewife Brook and in the upper Mystic and Malden Rivers is about $0.5,21$, and 12 million $\mathrm{ft}^{3}$, respectively. It was not possible to measure the thickness and the volume of soft sediment in the Lower Mystic Lake by the techniques used in this study. Sediment coring, however, indicates that the sediment is fairly thick (thicker than $4 \mathrm{ft}$ on average) and that there is a substantial volume of sediment in the lake.

\section{Results for Sediment Grab Samples}

Chemical data for surficial sediment can be used by water-resource managers to ensure that the quality of lakes, rivers, and estuaries in the Mystic River Basin is high enough to make the waterways safe for boating, swimming, and fishing. These data (table 3) can also be used to define objectives for managing and monitoring sediment quality. For example, the objectives might be to maintain the present quality of the sediment or to restore contaminant concentrations to background levels (concentrations not affected by human activities), to the levels of other urban rivers, or to levels safe enough for specific designated uses (for example, swimming or boating). Comparisons of contaminant concentrations measured in samples in Mystic River Basin sediments among sediment-sampling locations, to background concentrations, to concentrations from other urban rivers, and to sedimentquality guidelines could help local water-resource managers determine what actions might be needed to restore sediment quality.

A detection indicates that the constituent concentration is greater than the minimum reporting level (MRL) for a given analytical technique. A nondetection can indicate two possibilities: (1) the constituent is not present in the sample, or (2) the concentration of the constituent in the sample is less than the MRL. Nondetection of a constituent, therefore, does not necessarily indicate its absence. In particular, the organochlorine pesticide and PCB data collected for this study should be interpreted carefully because detection limits reported in this study are higher than the detection limits reported for other studies in which gas chromatography with electoncapture detectors was used. In other studies, total Aroclors have been reported; however, in this study, gas chromatography mass spectrometry (GCMS) was used because it is more accurate.

\section{Spatial Trends in Sediment Quality}

Concentrations of the 33 elements measured in grab samples are shown in table 3 by sampling location. The elements most often present at concentrations greater than 1,000 ppm are considered major elements and include calcium, iron, manganese, phosphorus, aluminum, potassium, sodium, and titanium. Concentrations of these elements differed greatly in the sediment samples collected, likely because the samples were collected in freshwater, estuarine, and saltwater environments.

Conversely, trace elements are those elements whose concentrations are typically less than $1,000 \mathrm{ppm}$ in uncontaminated sediment. Because of their toxicity, the USEPA has classified a few of these trace elements as priority pollutants (U.S. Environmental Protection Agency, 2002b) including antimony, arsenic, beryllium, cadmium, chromium, copper, lead, mercury, nickel, selenium, silver, thallium, and zinc. In this study, chromium (where data are available), copper, lead, nickel, and zinc were detected in every sample. Concentrations greater than the detection limits of arsenic, silver, beryllium, cadmium, mercury, and antimony were measured in 97, 94, $77,62,14$, and 1 percent of the samples tested, respectively. Concentrations of selenium and thallium were not measured in this study.

The highest median concentrations of priority pollutants—arsenic (70 ppm), cadmium (6 ppm), copper (290 ppm), nickel (37 ppm), and zinc (1,700 ppm) - were measured in sediment collected from Lower Mystic Lake (fig. 7). This was expected on the basis of the history of contamination in Upper Mystic Lake, which discharges directly into Lower Mystic Lake. The median concentrations of beryllium (1.2 ppm), lead (460 ppm), and silver (3.4 ppm) measured in the sample collected from Mill Creek were greater than the median concentrations of those elements measured in sediment collected from the other Mystic River Basin sites. Median concentrations of chromium (230 ppm, measured only downstream of the Amelia Earhart Dam) and tin (18 ppm) were highest in sediment collected from Chelsea Creek and the Malden River, respectively. 

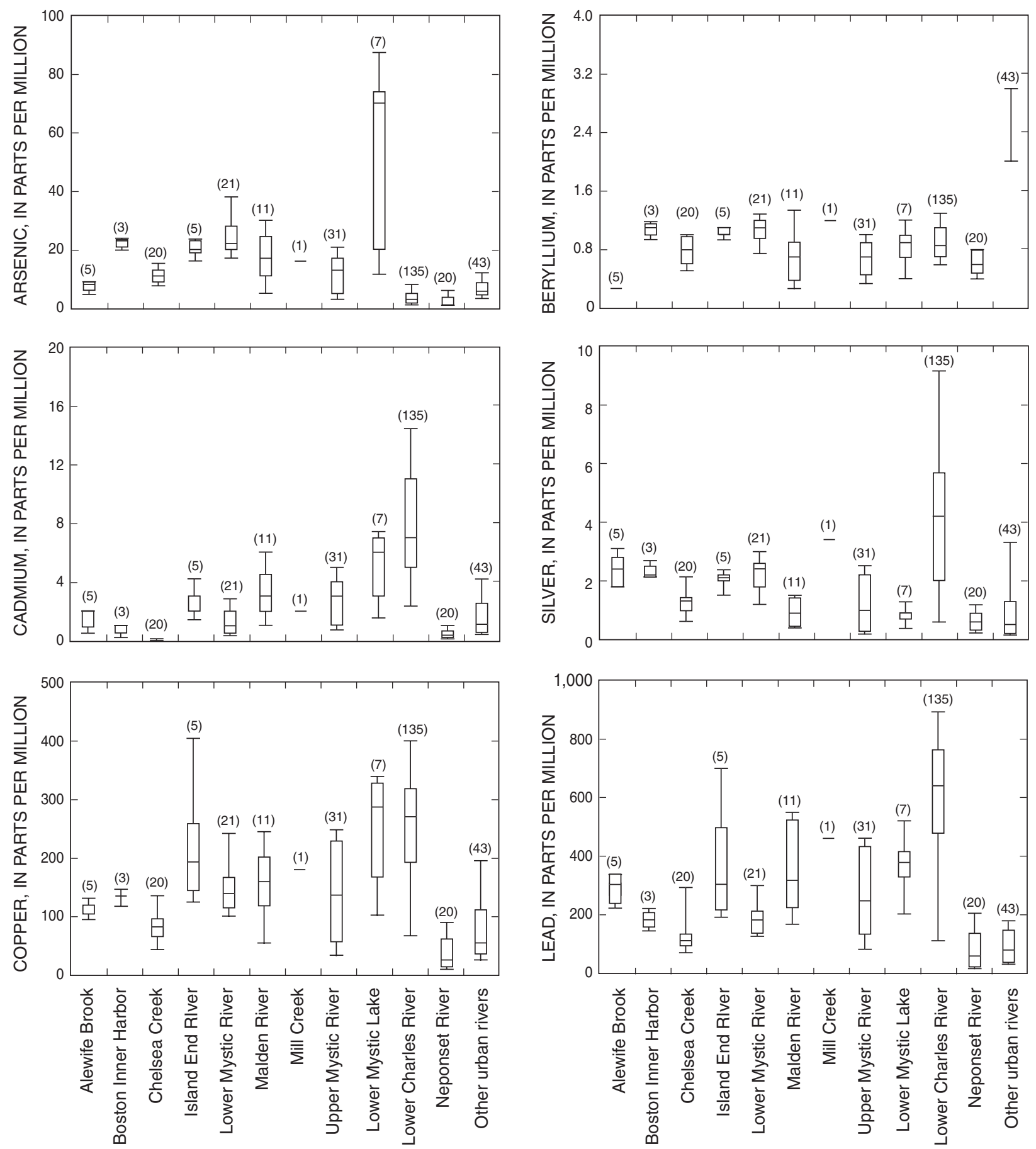

\section{EXPLANATION}

(42) Number of samples

Toth Percentile

75th Percentile

50th Percentile (Median)

25th Percentile

10th Percentile

Figure 7. Population statistics for element and polyaromatic hydrocarbon concentrations measured in grab samples collected from the Mystic River Basin, Massachusetts, and other urban rivers (2001-03). 

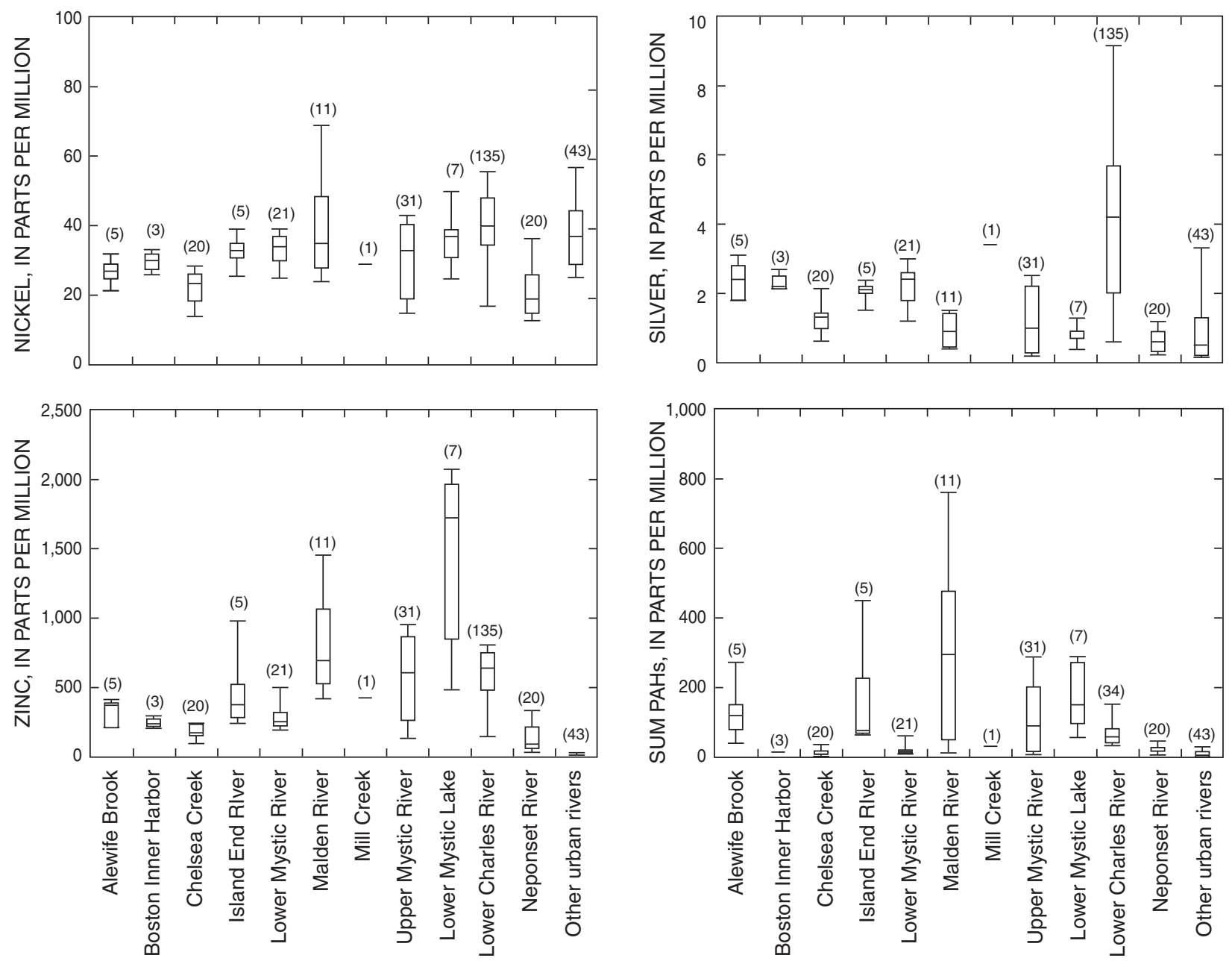

\section{EXPLANATION}

(42) Number of samples

T 90th Percentile

75th Percentile

50th Percentile (Median)

25th Percentile

10th Percentile

Figure 7-Continued. Population statistics for element and polyaromatic hydrocarbon concentrations measured in grab samples collected from the Mystic River Basin, Massachusetts, and other urban rivers (2001-03). 
Concentrations of the organic compounds tested are shown by site in table 3 . These organic compounds include three major groups: PAHs, organochlorine pesticides, and PCBs, which also appear on the USEPA's priority pollutant list (U.S. Environmental Protection Agency, 2002b). Group concentrations are expressed as the sum of concentrations of several related compounds; $\Sigma \mathrm{PAH}$, for example, is the sum of all tested PAHs; and EDDT is the sum of the concentrations of dichlorodiphenyltrichlorethane (DDT), dichlorodiphenyldichloroethane (DDD), and dichlorodiphenyldichlorethylene (DDE). PCBs were not added because no concentrations of PCBs were measured above detection limits.

Of the 15 PAHs analyzed in the grab samples, fluoranthene was the most commonly detected (in more than 90 percent of the samples). The least commonly detected PAH of those detected was naphthalene (in less than 3 percent). The median $\Sigma$ PAH concentration was highest (about 300 ppm) for samples collected from the Malden River (fig. 7). The grab sample with the highest $\Sigma$ PAH concentration (780 ppm) was collected from the Malden River at sampling site 43 (table 3). DDT, an insecticide banned in the United States in 1972 or one of its metabolites (DDD and DDE) were detected in only one of the grab samples (sampling site 63). The DDT concentration at this station was about $0.2 \mathrm{ppm}$. No other organochlorine pesticides were detected (detection limits ranged from 0.151 to $0.874 \mathrm{ppm}$ ). No measurable amounts of PCBs were detected in any of the samples collected (detection limits ranged from 0.11 to $0.251 \mathrm{ppm}$ ).

\section{Effects of Human Activities on Sediment Quality}

Concentrations of elements measured in grab samples from the freshwater part of the study area (upstream of the Amelia Earhart Dam) were compared to median concentrations of the same elements measured in fine-grained sediment collected from freshwater streams in Connecticut, Maine, Massachusetts, New Hampshire, New York, and Rhode Island. These sediment samples were collected between 1977 and 1980 as part of the National Uranium Resource Evaluation (NURE) program - specifically the Hydrogeochemical and Stream Sediment Reconnaissance (HSSR) program (Smith, 1998; Grossman, 1998)_and reanalyzed by the National Geochemical Survey by using modern (2000) methods (U.S. Geological Survey, 2003). A brief history of this program, as well as tabulated data, is available online (U.S. Geological
Survey, 2004). Concentrations of elements measured in sediment samples from the estuarine part of the study area (downstream of the Amelia Earhart Dam) were compared to concentrations thought to represent background for estuarine environments (Bowen, 1979).

The NURE HSSR program SOP instructed researchers to collect bottom-sediment samples from small uncontaminated streams (Ferguson and others, 1977), which were assumed to be unaffected by human activities. Element concentrations measured in these sediment samples are assumed to approximate nonurban background concentrations in New England streams. The samples collected by NURE HSSR and the samples collected in this study were processed by different methods (Ferguson and others, 1977). The NURE HSSR samples were passed through a $150-\mu \mathrm{m}$ sieve, whereas samples collected in this study were not sieved. This difference could affect the comparison because the NURE HSSR samples consisted of a higher proportion of fine-grained sediments, which have a higher surface area per unit weight than coarse sediments, and because contaminants typically adhere to sediment in proportion to surface area (Horowitz, 1991). Thus, concentrations in NURE samples may be high relative to concentrations in unsieved samples from the same locations; such unsieved samples would be more directly comparable to the samples of this study. The samples collected by NURE HSSR and the samples collected in this study were also analyzed by different methods. The stronger acid digestion used by NURE HSSR than that used in this study probably also resulted in higher concentrations in the NURE HSSR trace-element data.

Despite the possibility that concentrations in the NURE samples would be biased higher than in the Mystic River Basin samples, selected trace-element concentrations in Mystic River Basin samples (excluding antimony, cadmium, and mercury, for which NURE provided no chemical background data) were generally greater than background concentrations in the NURE samples or concentrations thought to represent background for estuarine environments (Bowen, 1979). Concentrations of arsenic, chromium, copper, lead, or zinc were greater than background at 82 percent or more of the sites sampled. Similarly, concentrations of nickel, beryllium, or silver were greater than background concentrations in nearly one-half of the grab samples. The widespread distribution of high concentrations of arsenic, chromium, copper, lead, and zinc in sediments throughout the Mystic River Basin strongly suggests the importance of human activities. 
Researchers may erroneously conclude that enrichment is caused by human activity, when the enrichment may actually be caused by natural processes. Many natural factors can cause bottom sediments to become enriched with trace elements above background levels, including differential weathering (related to solubilities of individual elements), physical fractionation (for example, the removal of fine particles by wind and water), chemical fractionation, and deposition of enriched atmospheric and biogenic dust (Reimann and De Caritat, 2000). In contrast, the history of dredging and channelization in the lower Mystic River, Chelsea Creek, and Boston Inner Harbor during the past 100 years may cause researchers to conclude erroneously that human activities have not affected sediment quality. Most recently (1998-2001), the Boston Harbor Navigation Improvement Project (BHNIP), a cooperative effort by the USACE and the Massachusetts Port Authority (MassPort), removed or redistributed about 3.5 million cubic yards of sediment (fig. 8). The objective of this project was to deepen parts of the lower Mystic River and Inner Harbor from $35 \mathrm{ft}$ mean lower low water ${ }^{1}$ (MLLW) to about $40 \mathrm{ft}$ MLLW, and parts of Chelsea Creek from $35 \mathrm{ft}$ MLLW to about $38 \mathrm{ft}$ MLLW. Most sediment was placed in confined aquatic disposal cells built within the federal navigation channels and in designated disposal sites in Massachusetts Bay. Those areas dredged by the BHNIP are shown in figure 8 . Thus, chemical analysis of grab samples collected from dredged areas during this study likely represents the chemistry of more recently deposited sediment (after 1998-2001) or, less likely, represents the chemistry of sediment deposited much earlier; the interpretation depends on sedimentation rates and resuspension patterns. In either case, grab samples can be used to measure existing (2001-03) sediment quality. Age dating of grab samples is beyond the scope of this project.

In contrast to trace elements, many of which occur naturally in bottom sediments, many organic compounds in sediment-for example, pesticides and PCBs—are not naturally occurring. Exceptions to this are the PAHs that are found in petroleum and in combustion emissions (for example, forest fires). Concentrations of naturally occurring PAHs are typically not very high in bottom sediments (about 1-10 ppm) (Massachusetts Department of Environmental Protection, 2002). Accordingly, the contamination of sediment by PAHs above $10 \mathrm{ppm}$ and many other organic compounds can be attributed to human activities.

\section{Comparison to Other Urban Rivers}

Concentrations of the selected trace elements (with the exception of mercury) and organic compounds were compared with concentrations of these constituents in samples collected from other urban rivers (whose drainage-basin areas have greater than 50 percent urban land use) throughout the conterminous United States as part of the National WaterQuality Assessment (NAWQA) Program of the USGS (Rice, 1999). Like the NURE HSSR sediment samples, samples collected by the NAWQA Program for analysis of trace metals and organic compounds were sieved (through 63- $\mu \mathrm{m}$ and 2-mm sieves, respectively). The procedure used by the NAWQA Program also includes a a stronger acid digestion than that used in this study. The sieving procedure and use of a stronger acid digestion probably resulted in higher concentrations than would have been obtained if the NAWQA samples had been processed and analyzed by using the methods of this study.

Concentrations of some selected trace elements (arsenic, chromium, copper, lead, silver, or zinc) in Mystic River sediments were greater than the median concentrations for those elements in sediment collected by the USGS NAWQA Program at 75 percent or more of the sites sampled (fig. 7). Concentrations of cadmium and nickel were also greater than the NAWQA median concentrations at 45 and 23 percent, of the sites, respectively. Beryllium concentrations from the Mystic River Basin were less than the median NAWQA beryllium concentration in samples from all of the sites but two. The $\Sigma \mathrm{PAH}$ concentration in samples collected from the Mystic River Basin was generally greater than the NAWQA median PAH concentration (87 percent of the sites). Total DDT and PCB concentrations could not be compared with NAWQA concentrations because DDT and PCB detection limits for this study were higher than the NAWQA median DDT and PCB concentrations, respectively.

A better comparison might be between concentrations in the Mystic River Basin sediments and in the sediments of the other two rivers tributary to Boston Harbor. Summary statistics of selected trace element and organic compound concentrations in bottom sediment collected from the lower Charles and Neponset Rivers, both of which are dammed (Breault and others 2000, 2004a), allow comparison of the quality of Mystic River Basin sediments to the quality of sediments in nearby urban rivers (fig. 7). Generally, concentrations of the selected trace elements (mercury was not included in the comparison because data for this element from the other rivers were not available) and $\Sigma$ PAHs were lower in the Mystic River Basin than in the lower Charles, but higher than in the Neponset River, with a few exceptions. Concentrations of arsenic were generally higher in the Mystic River Basin than in both the Charles and Neponset Rivers (fig. 7). Total DDT and PCB concentrations could not be compared with concentrations in samples from the Charles and Neponset Rivers because the detection limits for the Mystic River Basin samples were higher than for the samples collected in those studies.

\footnotetext{
${ }^{1}$ Mean lower low water is defined as the mean altitude of the lower of the two daily low-water altitudes over a period of time, typically 19 years (U.S. Geological Survey, 2005).
} 


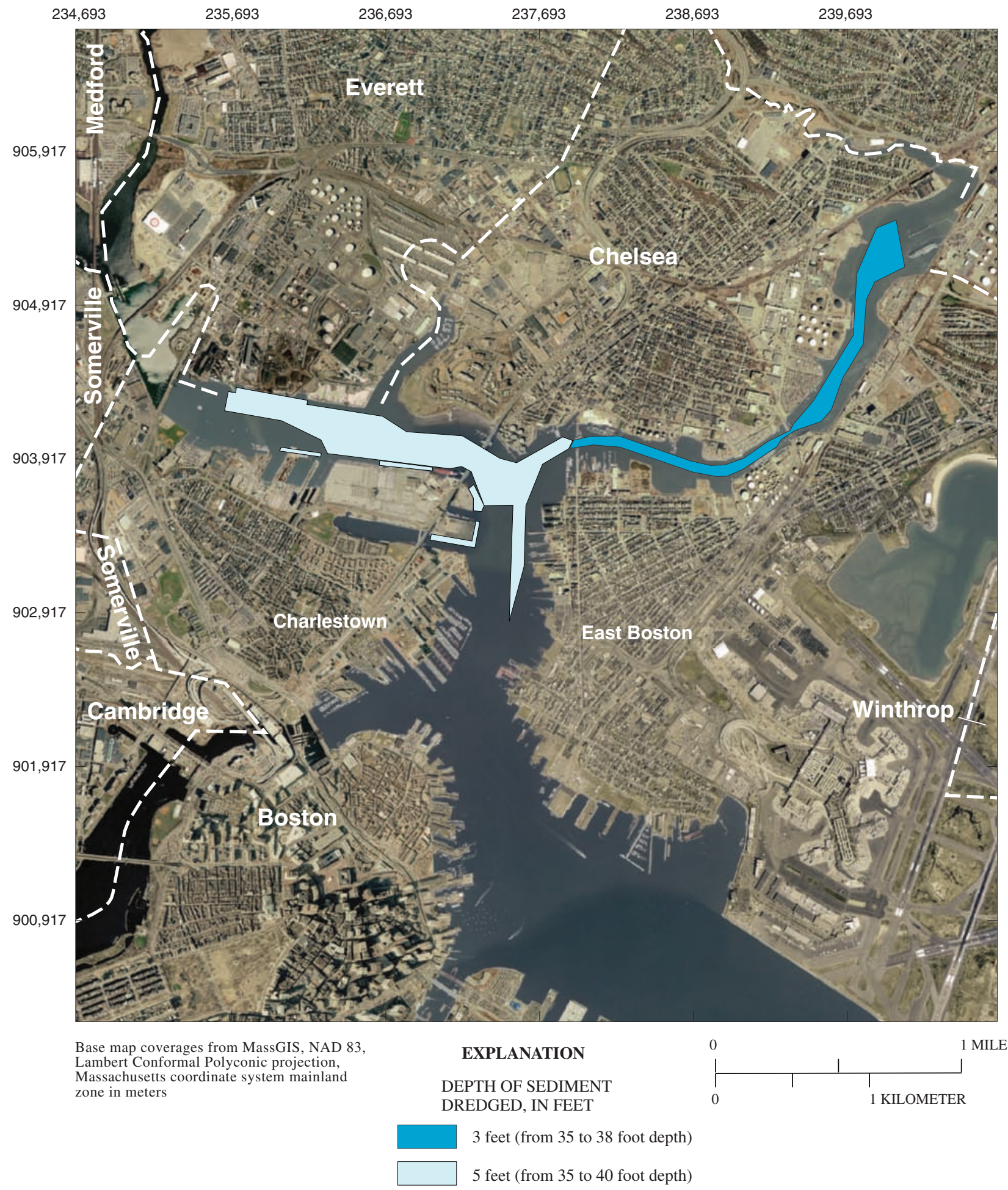

Figure 8. Areas dredged as part of the Boston Harbor Navigation Improvement Project, in which the lower Mystic River and Inner Harbor, Massachusetts, were deepened from 35 feet mean lower low water (MLLW) to about 40 feet MLLW (light blue) and parts of Chelsea Creek from 35 feet MLLW to about $38 \mathrm{ft} \mathrm{MLLW} \mathrm{(dark} \mathrm{blue).}$ 


\section{Results for Sediment Core Samples}

Chemical data from sediment cores can be used to (1) assess trends in contaminant concentrations, (2) determine the effects of human activities on sediment quality, and (3) investigate the distribution of new contaminants. Data from core samples can also be used by water-resources managers to monitor, assess, and plan restoration efforts aimed at improving sediment quality. Trends in sediment quality can be observed from concentration profiles measured in sediment cores. The effects of human activities on sediment quality can be inferred by correlating human activities with contaminant peaks in the cores collected in undisturbed areas.

\section{Trends in Sediment Quality}

Sediment core results for trace elements (table 4) show variability in concentration with depth at some sites and concentrations that are elevated relative to background (figs. 9-16, at back of report). For example, in the Lower Mystic Lake core from site 105, arsenic concentration was highest (310 ppm) at 77.5 to $81 \mathrm{~cm}$. These levels were substantially higher than background (about 20-40 ppm) as measured in deeper sediment strata. Although concentrations from the lake were lower in surface sediments (110 ppm) than at their peak, the concentrations were still much higher than background. This suggests either that there are contemporary inputs of arsenic to the lake or that arsenic in deeper sediment is remobilized to surfacesediment strata. Other results show that some trace-element concentrations are remaining constant, are only slightly lower in near-surface sediments, or show no trend at all with depth. For example, arsenic, beryllium, cadmium, lead, nickel, and silver concentrations measured in near-surface sediment samples collected from Island End River appear to remain constant with depth; other examples are shown in figures 9-16.

Concentrations of PAHs vary with depth at most sites (table 5). Some core samples show substantially lower concentrations of PAHs in surface layers compared to deeper layers. For example, in the Island End River core (sampling site 112, fig. 16), concentrations of PAHs decrease from $1,300 \mathrm{ppm}$ (measured in the sediment at a depth of 40-44 cm) to $72 \mathrm{ppm}$ in surficial sediment. It is likely that residual wastes from a coal-gasification plant that operated on the Island End River are the source of PAH contamination in the river (U.S. Environmental Protection Agency, 1999). In contrast, plots of $\Sigma$ PAHs measured in core samples from sampling sites 107, $108,109,110$, and 111 show a continuous increase in PAH concentrations with time. This trend is mirrored in cores from other urban areas across the United States (Van Metre and others, 2000). One possible source of contemporary PAHs is vehicular traffic, a byproduct of urban development, especially during the past 20-40 years. The Mystic River Basin has undergone considerable population growth during this time. There were only a few detections (fewer than six) of the pesticides; DDD (48-65 cm), DDT (73-77), and methoxychlor $(61-81 \mathrm{~cm})$ in cores collected from Lower Mystic Lake, one detection of methoxychlor in the core collected from the Malden River (75-78) and no detection of PCBs above the detection limit in core samples.

Sediment-concentration profiles can be greatly affected by several factors, most notably grain-size differences, bioturbation, diagenetic chemical processes, physical transport of contaminated sediment, and dredging. Generally, because fine sediment grains have much larger surface areas per unit weight than coarse sediment grains, fine grains of sediment have larger surface areas to which contaminants can adhere (Horowitz, 1991). Thus, observed increases or decreases in contaminant concentrations within a core might simply be a result of increases or decreases in grain sizes instead of changes in contaminant loading. Although grain-size information was unavailable for core-sample data from the Mystic River Basin, "conservative elements" like aluminum and titanium can be used as an empirical proxy (Horowitz, 1991). Fine-grained sediment would be expected to have a greater proportion of these elements per unit weight than coarse-grained sediment. Plots of contaminant concentrations divided by aluminum (aluminum-normalized) or titanium (titanium-normalized) concentrations can, therefore, be used to elucidate trends (figs. 9-16; Horowitz, 1991). Aluminumnormalized trace-element concentrations were calculated by dividing each trace-element concentration, in parts per million, by the concentration of aluminum (in percent) measured in the same sample. Similarly, titanium-normalized trace element concentrations were calculated by dividing the concentration of each contaminant by the concentration of titanium. Concentrations of titanium (in percent) were first multiplied by 10 (figs. 9-13, and 15) and by 100 (fig. 14) for purposes of scale (figs. 9-16). These plots show little change in depositional history, therefore, changes in contaminant concentrations can be interpreted as changes in contaminant loading.

Bioturbation refers to the mixing of the upper layers of bottom sediment by organisms that live in and on the bottom sediment-for example, worms, snails or crabs. As these creatures move through or ingest the sediment, they can homogenize sediment layers that may have been deposited over several tens of centimeters (Berner, 1980; Matisoff, 1995). Bioturbation can also increase the exchange of contaminants from the sediment into the water column (Bencala and other, 1984; Berg and others, 2001). For example, researchers working with lugworms have shown that the remobilization of cadmium from sediments with lugworms was three to five times greater than from sediment without lugworms (Rasmussen and others, 2004). Diagenetic chemical processes take place after a chemical is deposited in the sediment. Several processes might redistribute a given chemical after deposition, including equilibrium processes, homogeneous reactions, microbial reactions, precipitation, dissolution, and authigenic processes (Berner, 1980). The physical transport of contaminated sediment by waves, currents, or other physical processes 
can also affect down-core chemistry. Physical transport of contaminants with suspended sediment might also result in the sorbtion or desorption of contaminants (Bonner and others, 1994). Finally, recent dredging of parts of the lower Mystic River, Boston Inner Harbor, and Chelsea Creek has affected the observed contaminant trends.

\section{Human Activities and Sediment Quality}

It may be possible to reconstruct the history of human influence in the Mystic River Basin on sediment quality by using core samples. This is particularly true for samples collected from Lower Mystic Lake, because the history of human activities in the drainage basin just upstream of the lake has been well documented (Splietfhoff and Hemond, 1996). Although dates were not assigned to sediment depths in the cores collected in this study, sediment samples from Upper Mystic Lake collected, chemically analyzed, and dated by others could be used to corroborate the interpretation of sediment-quality data in Lower Mystic Lake. Possible coincidences can be identified between peak concentrations of specific contaminants in the core sample collected at site 105 in Lower Mystic Lake and activities that produced those contaminants in the lake's drainage area.

The Aberjona River flows into Upper Mystic Lake, which drains into Lower Mystic Lake. The Aberjona River flows through one of the best-known Superfund sites in the Nationthe Industri-Plex in Woburn, MA. Between the 1860s and 1980s, six different chemical manufacturing companies operated on this site, and produced chemicals used by the leather and textile industries, arsenic- and lead-based pesticides, sulfuric acid, and explosives used during both World Wars. Byproducts of these manufacturing processes were often disposed of in areas near and directly adjacent to the Aberjona River. The arsenic-concentration maximum measured in the Lower Mystic Lake sediment core (sampling site 105, fig. 9) may correspond with the first of two major episodes of arsenic contamination in the basin in the early 1900s (Spliethoff and Hemond, 1996; Knox, 1991). The source of this arsenic is believed to be pyrites used in the manufacturing of sulfuric acid at the Industri-Plex site (Aurilio and others, 1995). Additionally, the arsenic peak measured at site 105 roughly corresponds with peaks of other contaminant concentrations. These peaks may indicate a period of substantial contaminant transport in the basin.

Concentrations of lead can also be related to human activities in the basin. For example, the use of lead as a gasoline additive reached a maximum in the mid-1970s, at which time it was phased out by the USEPA. A high concentration of lead $(1,600 \mathrm{ppm})$ was measured at a depth of $32.5 \mathrm{~cm}$ to $36.5 \mathrm{~cm}$ in the sediment core collected from site 105 in Lower Mystic Lake. The highest concentrations of lead and other metals were at depths between 61 and $97 \mathrm{~cm}$ in sediment cores from the lake. This depth may correspond to the years between
1914 and 1947 when munitions used in both World Wars were manufactured in industrial plants just upstream of Lower Mystic Lake.

The maximum $\Sigma$ PAH concentration (1,200 ppm) measured at sample site 105 in Lower Mystic Lake occurred at a depth of 73 to $77 \mathrm{~cm}$, which may correspond approximately to the period 1930-35. The most likely source of these PAHs is tar from a coal-gasification plant that operated in Arlington between 1900 and 1930. Finally, a large spike in the concentration of silver $(8.3 \mathrm{ppm})$ was measured at sample site 105 at a depth of 40.5 to $44.5 \mathrm{~cm}$ (fig. 9). The source of this silver is unknown.

\section{Toxicity of Contaminated Bottom Sediment}

Contaminant concentrations in sediment-grab samples were compared to sediment-quality guidelines and to exposure-based soil standards to assess the potential health risks posed by the Mystic River Basin sediments to bottomdwelling organisms and to humans.

\section{Benthic Organisms}

One way to assess whether a river can support a healthy and diverse population of fish is to test the health of their food source, particularly benthic organisms. Benthic organisms (for example, worms, snails, or crabs) live and feed on the river bottom, where they come in direct contact with contaminated sediment. Contaminants can accumulate in the tissues of these organisms as they ingest sediment contaminated with elements and organic compounds or sorb these contaminants directly from sediment and water (Forstner and Whittman, 1983). Accumulation of these constituents in benthic organisms can cause physiological problems, reproductive problems, and death. Subsequent ingestion of contaminated benthic organisms by other organisms higher in the food chain (for example, fish) can cause similar health effects.

The potential toxicity of Mystic River sediment to benthic organisms can be estimated by comparing measured concentrations for individual contaminants and contaminant types to probable effect concentrations (PECs), which are published guidelines (Ingersoll and others, 2000). The guidelines are based on the results of laboratory tests in which organisms such as the amphipod Hyalella azteca and the insect larva Chironomus spp. were exposed to different concentrations of contaminants. The predicted potential for toxicity depends on the organism and on the test conditions in general; however, concentrations higher than the PECs are considered likely to be toxic to benthic organisms. Average PEC quotients can be calculated for individual sediment samples in which concentrations of more than one contaminant have been measured. The quotient for a given sample is a measure of the toxicity 
caused by more than one contaminant in that sample. Finally, the average PEC quotient can be compared to PEC-quotient ranges associated with different toxicity potentials (Ingersoll and others, 2000).

Censored data was treated somewhat differently in the calculation of average PEC quotients than in the calculations of total concentrations. Censored data were set to one-half of the detection limit (instead of zero) unless all constituents in the group were below the detection limit, in which case the detection limits themselves were added. In addition, if a constituent's concentration was below the detection limit and the limit was greater than the PEC for that constituent, it was eliminated in the calculation of the PEC quotient (Ingersoll and others, 2000). In this study, concentrations of the PAHs acenaphthene, naphthalene, acenaphthylene, and dibenzo $[a, h]$ anthracene were eliminated for this reason.

To calculate the average PEC quotient for a given sample of sediment, a measured concentration of a specific contaminant was adjusted for censored data in the manner described above. If the published PEC is for an individual contaminant, the concentration of that individual contaminant is divided by its PEC value; if the published PEC is for a contaminant type, however, the total concentration for that type is divided by the PEC. Then the quotients are added, and the total is divided by the number of contaminants and types. In this study, PECs for seven individual trace elements and for total PAHs were used. These were the only types of contaminants used to calculate the PEC quotients. The average PEC quotient for each sample was calculated according to the equation

where

$$
Q_{x}=\frac{\sum \frac{C_{x, y}}{P E C_{y}}}{n_{x}}
$$

$Q_{x}$ is the average PEC quotient for sample $x$;

$C_{x, y}$ is the concentration of contaminant $y$ or contaminant type $y$ in sample $x$;

$P E C_{y}$ is the PEC for contaminant $y$ (Ingersoll and others, 2000); and

$n_{x}$ is equal to the number of contaminants and contaminant types used in sample $x$.

The PAH group included anthracene, benzo $(a)$ anthracene, benzo $(a)$ pyrene, chrysene, fluorene, fluoranthene, phenanthrene, and pyrene. The individual trace elements, each of which had its own PEC, included arsenic (As), cadmium $(\mathrm{Cd})$, chromium $(\mathrm{Cr})$, copper $(\mathrm{Cu})$, lead $(\mathrm{Pb})$, nickel $(\mathrm{Ni})$, and zinc $(\mathrm{Zn})$. As a result, $n_{x}$ could be as high as 8 .

The potential for toxicity was determined for the top 2-4 in. of bottom sediment, which can be considered the biologically active sediment layer (Baudo and Muntau, 1990). The average estimated potential-toxicity values at sampling sites in the Mystic River Basin for the test organisms (Hyalella azteca and Chironomus spp.) are shown in figure 17 (at back of report). The potential toxicity in figure 17 refers to the potential toxicity compared to a set of reference toxicity tests (Ingersoll and others, 2000). For example, an estimated potential toxicity of 20 percent means that 20 out of 100 toxicity tests are likely to show some level of toxicity for the concentration of contaminants measured in that sediment sample.

The average predicted potential toxicity ranged from about 13 to 97 percent among the sampling locations (fig. 17). Overall, the trace elements and the PAHs are responsible for as much as 50 percent of the predicted toxicity. In some areas, however, trace elements are more responsible for the predicted toxicity, and in other areas PAHs appear to be more responsible for the predicted toxicity. On average, trace elements are most responsible for the predicted toxicity of sediment grab samples collected from Boston Inner Harbor (69 percent), Chelsea Creek (67 percent), the lower Mystic River (68 percent), and Mill Creek (59 percent). In contrast, PAHs are most responsible for predicted toxicity of sediment samples collected from Alewife Brook (73 percent), Island End River (74 percent), Malden River (72 percent), and the upper Mystic River (61 percent). Trace elements and PAHs are each responsible for about one-half of the predicted toxicity for sediment samples collected from Lower Mystic Lake. The largest overall PEC quotient (13.7) was calculated for grab-sampling site 43 in the Malden River. In fact, PAHs accounted for most (96 percent) of the PEC quotient at this location. Similar results were obtained even when biased (high) chromium data (not shown) were used.

This evaluation of potential toxicity is intended to distinguish groups of chemicals that are likely to be associated with adverse biological effects at specific locations. This treatment of the data is intended to supplement, not substitute for, direct measures of sediment toxicity.

\section{Humans}

When people recreate in lakes, rivers, and estuaries, they often come in contact with sediment. Consequently, communities like those in the Mystic River Basin may benefit from information about the potential human-health risks associated with direct contact or incidental ingestion of contaminated sediment. These risks can be assessed by comparing contaminant concentrations with exposure-based guidelines for those contaminants (Massachusetts Department of Environmental Protection, 1996, method 2, soil category S-1). The guidelines can be applied only indirectly to aquatic sediment, however, because they are formulated for contaminated upland soil. In the absence of aquatic-sediment guidelines, comparison with direct-contact, exposure-based soil standards for many trace elements and organic compounds may suffice. 
Comparing sediment concentrations to soil-based human-health standards likely overestimates the potential human-health risk. As people wade or swim near contaminated sediment, the sediment is washed quickly from their skin. On the other hand, people exposed to contaminated soils typically experience extended contact with the soil; therefore, the contaminant is more likely to enter the body. Nonetheless, the comparison can provide a sense of the risk associated with contacting the sediment. These comparisons, however, are not intended to replace direct measures of the health risk.

Several of the constituents were detected at concentrations near or above their respective human-health standards for soil. Of the trace elements, concentrations of antimony (at 1 sample site), arsenic (9 sample sites), beryllium (61 sample sites), lead (39 sample sites), and zinc (1 sample site) were closest to their respective standards for soil. Of particular interest is the beryllium concentration that was measured at Chelsea Creek (sample site 99) at more than 11 times the standard for soil. Lead and zinc concentrations at this site were also greater than the soil-standard concentrations of lead and zinc by six and two times, respectively. Of the organic compounds tested, the PAHs - benzo[a]anthracene (at 72 grab-sampling sites), benzo(b)fluoranthene and benzo $[k]$ fluoranthene (38 sample sites), benzo[a]pyrene (83 sample sites), chrysene (36 sample sites), dibenzo[ $a, h]$ anthracene (22 sample sites), indeno[1,2,3-cd]pyrene (54 sample sites), and naphtalene (1 sample site)—were closest to human-health standards for soil. On the basis of the analysis methods described previously for censored data, none of the organochlorine pesticides tested showed potential for adverse humanhealth risk based on soil standards. The human-health effects of PCBs could not be assessed because of the high detection limits in this study.

\section{Summary}

Surface-sediment and sediment-core samples from Lower Mystic Lake, Mystic River, Alewife Brook, Malden River, Island End River, Chelsea and Mill Creeks in the Mystic River Basin were tested for the presence of pesticides, polyaromatic hydrocarbons (PAHs), polychlorinated biphenyls, and selected elements, including antimony, arsenic, beryllium, cadmium, chromium, copper, lead, mercury, nickel, silver, and zinc. Both types of samples were generally enriched in toxic elements and organic compounds when compared to background concentrations. In addition, most constituent concentrations - in particular, arsenic, chromium, copper, lead, silver, or zinc, and PAHs - were equal to or greater than those found in the sediments of other urban rivers. With a few exceptions, concentrations of the selected trace elements and PAHs were lower in the Mystic River Basin sediments than in the sediments of the lower Charles, but higher than or equal to concentrations in the sediments of the Neponset River-each a tributary to Boston Harbor. Concentrations of arsenic were generally higher in the Mystic River Basin than in both the lower Charles and Neponset Rivers. Some chemicals are in sufficiently high concentrations in sediment samples collected from the Mystic River Basin to pose a threat to benthic organisms and, based on guidelines developed for upland soils, and may cause human-health risks if humans come in contact with the sediment.

Sediment core results show that trace-element concentrations within the upper parts of the cores (more recently deposited sediment) have remained constant or have slightly declined, on average. In contrast, concentrations of PAHs appear to be increasing in near-surface sediment compared to sediment deposited earlier. Taken as a whole, however, graphs of sediment-core data show that the concentrations of trace elements and PAHs in surficial sediment are substantially lower than in sediment at depth. These trends imply that, although the sediment quality in the Mystic River Basin remains impaired and shows little improvement over recent years, the sediment quality has improved markedly since the turn of the century.

\section{Acknowledgments}

The authors express their gratitude to the following USGS employees for their cooperation and assistance: Stacey Archfield, Jason Sorenson, and Joseph Zanca for assistance with sampling; and Marcus Waldron, John Colman, Jonathan Morrison, and Leslie DeSimone for technical and editorial assistance: Alex Gorshteyn and Zinoviy Katayenko (Tuft University) for chemical analysis of sediment samples.

\section{References Cited}

Aurilio, A., Durant, J.L., and Hemond, H.F., 1995, Sources and distribution of arsenic contamination in the Aberjona Watershed, eastern Massachusetts: Water, Air, and Soil Pollution, v. 81, p. 265-282.

Aurilio, A., Mason, R., and Hemond, H.F., 1993, Speciation and fate of arsenic in three lakes of the Aberjona watershed, eastern Massachusetts: Environmental Science and Technology v. 28, p. 577-585.

Baudo, R., and Muntau, H., 1990, Lesser known in-place pollutants and diffuse source problems, in Baudo, R., Giesy, J., and Muntau, H., eds., Sediment chemistry and toxicity of in-place pollutants: Boston, MA, Lewis Publishers, Inc., $405 \mathrm{p}$. 
Bencala, K.E., Kennedy, V.C., Zellweger, G.W., Jackman, A.P., and Avanzino, R.J., 1984, Interactions of solutes and streambed sediment, 1. An experimental analysis of cation and anion transport in a mountain stream: Water Resources Research, v. 20, p. 1797-1803.

Berg, P., Rysgaard, S., Funch, P., and Sejr, M.K., 2001, Effects of bioturbation on solutes and solids in marine sediments: Aquatic Microbial Ecology, v. 26, p. 81-94.

Berner, R.A., 1980, Early diagenesis-A theoretical approach: Princeton, NJ, Princeton University Press, 241 p.

Bonner, J.S., Ernest, A.N., Autenrieth, R.L., and Ducharme, S.L., 1994, Parameterizing models for contaminated sediment transport, in DePinto, J.V., Lick, W., and Paul, J.P., eds., Transport and transformation of contaminants near the sediment-water interface: Ann Arbor, MI, CRC Press, Inc., $351 \mathrm{p}$.

Bowen, H.J.M., 1979, Environmental chemistry of the elements: London, England, Academic Press, 316 p.

Breault, R.F., Cooke, M.G., and Merrill, Michael, 2004a, Data on sediment quality and concentrations of polychlorinated biphenyls from the lower Neponset River, Massachusetts, 2002-03: U.S. Geological Survey Open-File Report 2004$1280,55 \mathrm{p}$.

Breault, R.F., Reisig, K.R., Barlow, L.K., and Weiskel P.K., 2000, Distribution and potential for adverse biological effects of inorganic elements and organic compounds in bottom sediment, Lower Charles River, Massachusetts: U.S. Geological Survey Water-Resources Investigations Report 00-4180, 70 p.

Buchholtz ten Brink, M.R., Manheim, F.T., Mecray, E.L., Hastings, M.E., and Currence, J.M., along with Farrington, J.W., Fredette, T.J., Jones, S.H., Larsen, P.F., Liebman, M.L., Smith Leo, W., Tripp, B.W., Wallace, G.T., Jr., and Ward, L.G., 2002, Contaminated sediments database for the Gulf of Maine, U.S. Geological Survey Open-File Report 02-403, accessed on March 23, 2004, at http:// pubs.usgs.gov/of/2002/of02-403/

Chelsea Historical Society, 2004, The second engagement of the Revolutionary War, accessed on March 17, 2004, at http://www.olgp.net/chs/war/second.htm de Groot, A.J., 1995, Metals and sediments-A global perspective, in Allen, H.E., eds., Metal contaminated aquatic sediments: Chelsea, MI, Ann Arbor Press, Inc., 292 p.

DePinto, J.V., Lick, W., and Paul, J.F., 1994, in DePinto, J.V., Lick, W., and Paul, J.F., eds., Transport and transformation of contaminants near the sediment-water interface: Boca Raton, FL, CRC Press, Inc., 351 p.

Durant, J.L., Zemach, J.J., and Hemond, H.F., 1990, The history of leather industry waste contamination in the Aberjona River watershed-A mass balance approach: Civil Engineering Practice, v. 5, p. 41-66.

Ferguson, R.B., Price, Van, and Baucom, E.I., 1977, Field manual for stream water and sediment reconnaissance: E.I. du Pont de Nemours \& Co., Savannah River Laboratory, Aiken, S.C., SRL Internal Doc. DPST-76-363, U.S. Department of Energy, Grand Junction, Colorado, GJBX80(77), $78 \mathrm{p}$.

Forstner, U., and Wittman, G.T.W., eds., 1983, Metal pollution in the benthic environment: New York, Springer Verlag, $486 \mathrm{p}$.

Grossman, J.N., 1998, National geochemical atlas-The geochemical landscape of the conterminous United States derived from stream sediment and other solid sample media analyzed by the national uranium evaluation (NURE): U.S. Geological Survey Open-File Report 98-622, ver. 3.01, 1 CD-ROM.

Heinz Center, 2002, Dam removal science and decision making: Washington, D.C., The H. John Heinz III Center for Science, Economics, and the Environment, 221 p.

Helsel, D.R., and Cohn, T.A., 1998, Estimation of descriptive statistics for multiply-censored water-quality data: WaterResources Research, v. 24, n. 12, p. 1997-2004.

Horowitz, A.J., 1991, A primer on sediment-inorganic element chemistry ( 2 d ed.): Boca Raton, FL, Lewis Publishers, $136 \mathrm{p}$.

Ingersoll, C.G., MacDonald, D.D., Wang, N., Crane, J.L., Field, L.J., Haverland, P.S., Kemble, N.E., Lindskoog, R.A., Severn, C., and Smorong, D.E., 2000, Prediction of sediment toxicity using consensus-based freshwater sediment quality guidelines: Chicago, IL, U.S. Environmental Protection Agency, EPA 905/R-00/007, June 2000, 25 p. 
Knox, M.L., 1991, The distribution and depositional history of metals in surface sediments of the Aberjona River watershed: Boston, MA, M.S. Thesis, Massachusetts Institute of Technology, variously paged.

Manheim, F., Buchholtz ten Brink, M., Hastings, P., and Mecray, E., 1999, Contaminated-sediment database development assessment in Boston Harbor: U.S. Geological Survey Fact Sheet FS-078-99, accessed on March 22, 2004, at http://pubs.usgs.gov/fs/fs78-99/

Matisoff, G., 1995, Effects of bioturbation on solute and particle transport in sediments, in Allen, H.E., ed., Metal contaminated sediment: Chelsea, MI, Ann Arbor Press, 292 p.

Massachusetts Department of Environmental Protection, 1996, Massachusetts contingency plan: Boston, MA, Massachusetts Department of Environmental Protection, variously paged.

Massachusetts Department of Environmental Protection, 2002, Background levels of polycyclic aromatic hydrocarbons and metals in soil, accessed on February 11, 2004, at http:// www.state.ma.us/dep/ors/files/backtu.pdf.

Montgomery, D.R., and Buffington, J.M., 1998, Channel processes, classification, and response, in Naiman, R.J., and Bilby, R.E., eds., River ecology and management: New York, Springer-Verlag, 705 p.

Mystic River Watershed Association, 2003, Mystic River Watershed Association water quality monitoring: Malden River May 28, 2002, accessed on March 17, 2004, at http:// www.mysticriver.org/publications/malden2002.pdf.

Mystic River Watershed Association, 2004, Water pollution, accessed on March 18, 2004, at http://www.mysticriver.org/ about_watershed/pollution.html

Nangle Consulting Associates, 2000, Interim data submittal, Malden River Corridor, U.S. EPA Brownfields Program, TeleCom City Everett-Malden-Medford, Massachusetts: Canton, MA, Nangle Consulting Associates, variously paged.

Rasmussen, D., Banta, G., and Andersen, O., 2004, Lugworm bioturbation affects cadmium water/sediment transfer and distribution, accessed on July 22, 2004, at http://www.aslo.org/meetings/santafe99/abstracts/ SS30FR1145S.html
Reimann, C., and DeCaritat, P., 2000, Intrinsic flaws of elemental enrichment factors in environmental geochemistry, Environmental Science and Technology, v. 34, n. 24, p. 5084-5091.

Rice, K.C., 1999, Inorganic-element concentrations in streambed sediment across the conterminous United States: Environmental Science \& Technology, v. 33, n. 15, p. 2499 2504.

Scott, J.C., 1990, Computerized stratified random siteselection approached across the conterminous United States: Environmental Science and Technology; v. 33, n. 15, p. 2499-2504.

Smith, S.M., 1998, History of the national uranium resource evaluation hydrogeochemical and stream sediment reconnaissance program: U.S. Geological Survey National Geochemical Database, Open-File Report 97-492, accessed on March 12, 2003, at http://pubs.usgs.gov/of/1997/ ofr-97-0492/nurehist.htm

Spliethoff, H.M., Mason, R.P., and Hemond, H.F., 1995, Interannual variability in the speciation and mobility of arsenic in a dimictic lake: Environmental Science and Technology, v. 29, n. 8, p. 2157-2161.

Spliethoff, H.M., and Hemond, H.F., 1996, History of toxic metal discharge to surface waters of the Aberjona watershed: Environmental Science and Technology, v. 30, no.1, p. 121-128.

Sly, P.G., 1994, The impact of physical processes at the sediment/water interface in large lakes, in DePinto, J.V., Lick, W., and Paul, J.P., eds., Transport and transformation of contaminants near the sediment-water interface: Ann Arbor, MI, CRC Press, Inc., 351 p.

U.S. Environmental Protection Agency, 1999, Chelsea River oil hazards survey: Boston, MA, U.S. Environmental Protection Agency, variously paged.

U.S. Environmental Protection Agency, 2002a, National recommended water-quality criteria: U.S. Environmental Protection Agency EPA-822-R-02-047, 36 p.

U.S. Environmental Protection Agency, 2002b, EPA Numeric criteria, accessed on July 19, 2004, at http:// oaspub.epa.govwqsdatabase/wqsi_epa_criteria.rep_ parameter 
U.S. Environmental Protection Agency, 2003a, EPA, DEP to focus on Mystic River Cleanup: U.S. Environmental Protection Agency, Boston, MA, 14 p., accessed on March 17, 2004, at http://www.epa.gov/NE/pr/1998/113098.html

U.S. Environmental Protection Agency, 2003b, Waste site cleanup and reuse in New England, accessed on September 12, 2005, at http://yosemite.epa.gov/r1/npl_pad.nsf/0/ 7692eb076450cc585256da900065d4be?opendocument\#toc

U.S. Geological Survey, 2003, Arsenic in New EnglandGeology, geochemistry, database and statistics, accessed on February 2, 2004, at http://minerals.usgs.gov/east/ environment/indexAsNEng.htm\#overview

U.S. Geological Survey, 2004, The National geochemical survey_Database and documentation: U.S. Geological Survey Open-File Report 2004-1001, accessed on February 2, 2004, at http://tin.er.usgs.gov/geochem

U.S. Geological Survey, 2005, Glossary, in Welcome to the USGS research site for sfports, accessed October 4, 2005, at http://sfports.wr.usgs.gov/SFPORTS/glossary.html
Van Metre, P., Mahler, B.J., and Furlong, E.T., 2000, Urban sprawl leaves its PAH signature: Environmental Science and Technology, v. 34, no.19, p. 4064-4070.

Weiskel, P.K., Barlow, L.K., and Smieszek, T.W., 2005, Water resources and the urban environment, lower Charles River watershed, Massachusetts, 1630-2005: U.S. Geological Survey Circular 1280, 46 p.

Wernstedt, K., and Probst, K.N., 1997, Land use and remedy selection-Experience from the field - the IndustriPlex Site, Resources for the future, Washington, D.C., 49 p., accessed on July 21, 2004, at http://www.rff.org/ Documents/RFF-DP-97-27.pdf.

Zarriello, P.J., Breault, R.F., and Weiskel, P.K., 2003, Potential effects of structural controls and street sweeping on stormwater loads to the lower Charles River, Massachusetts: U.S. Geological Survey Water-Resources Investigations Report 02-4220, 48 p. 
Figures 9-17 



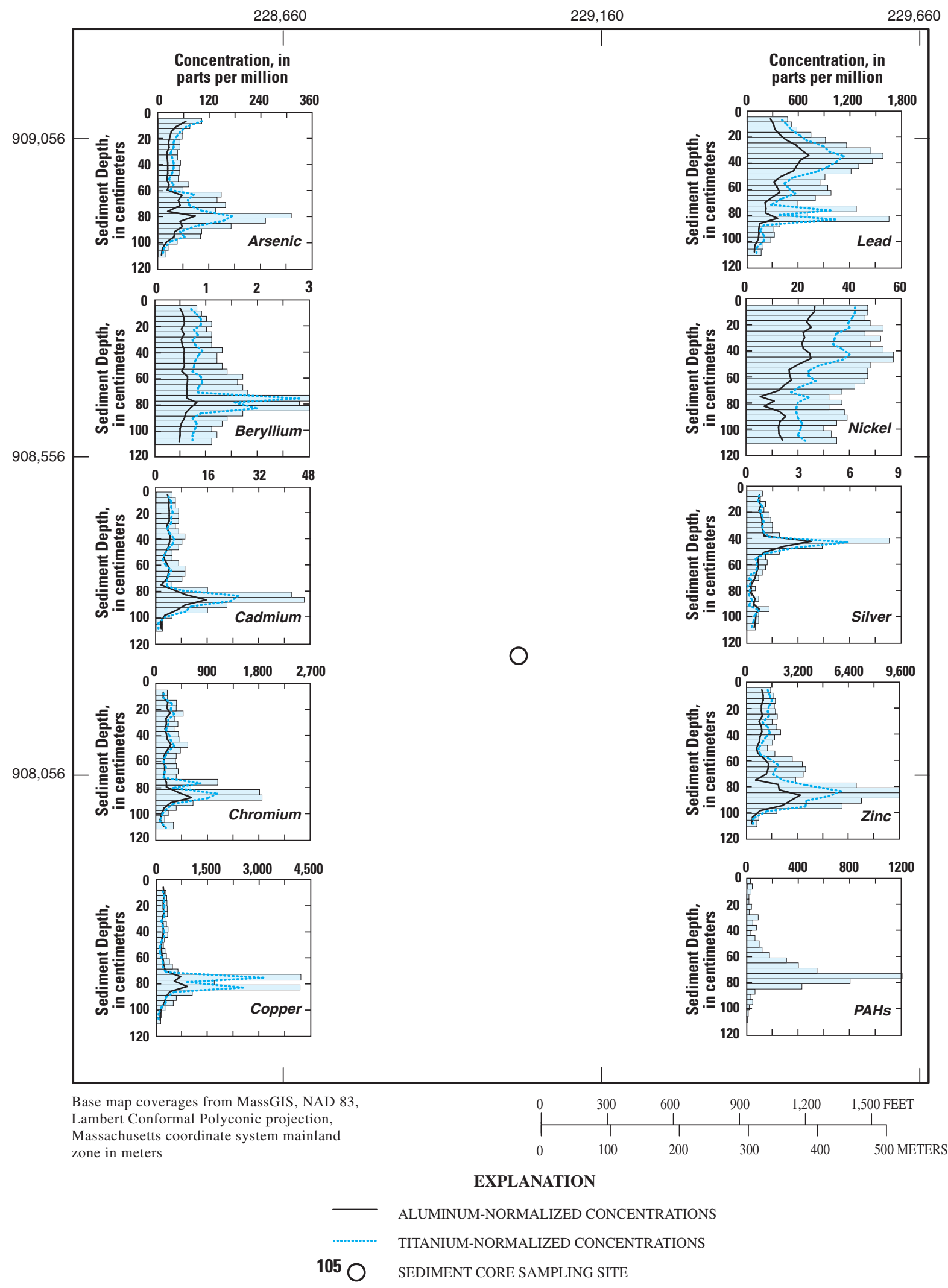

Figure 9. Selected trace element and organic compound concentrations measured in sediment core samples collected from site 105, Lower Mystic Lake, Mystic River Basin, Massachusetts. Data for trace elements were not analyzed for depth range $0-4$ centimeters because the entire volume of sediment in this range was needed for organic analysis. 


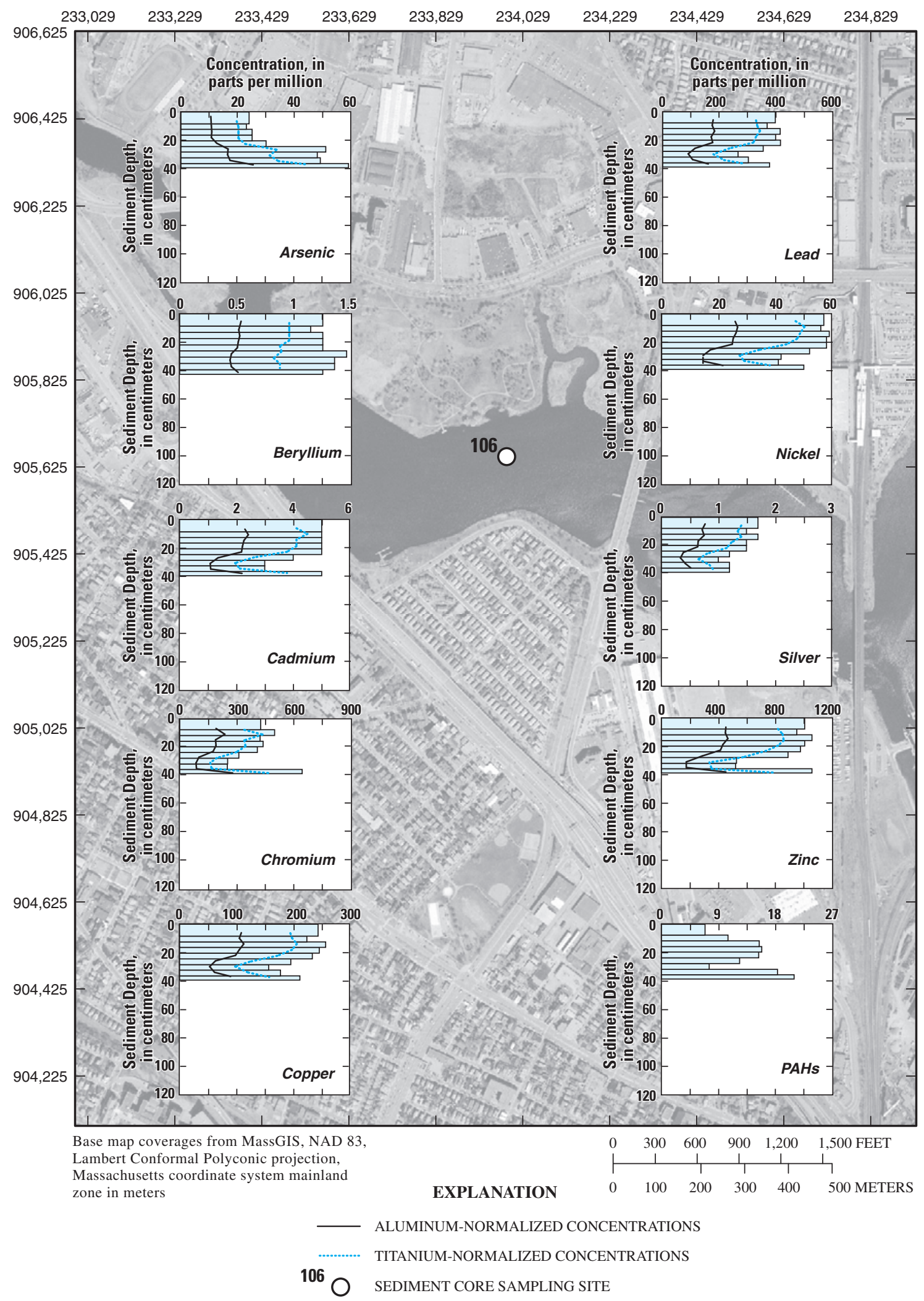

Figure 10. Selected trace element and organic compound concentrations measured in sediment core samples collected from site 106, upper Mystic River above Amelia Earhart Dam, Mystic River Basin, Massachusetts. Samples from depth ranges $0-4$ and 4-8 centimeters were combined because high water content reduced the volume of sediment in the individual samples. 


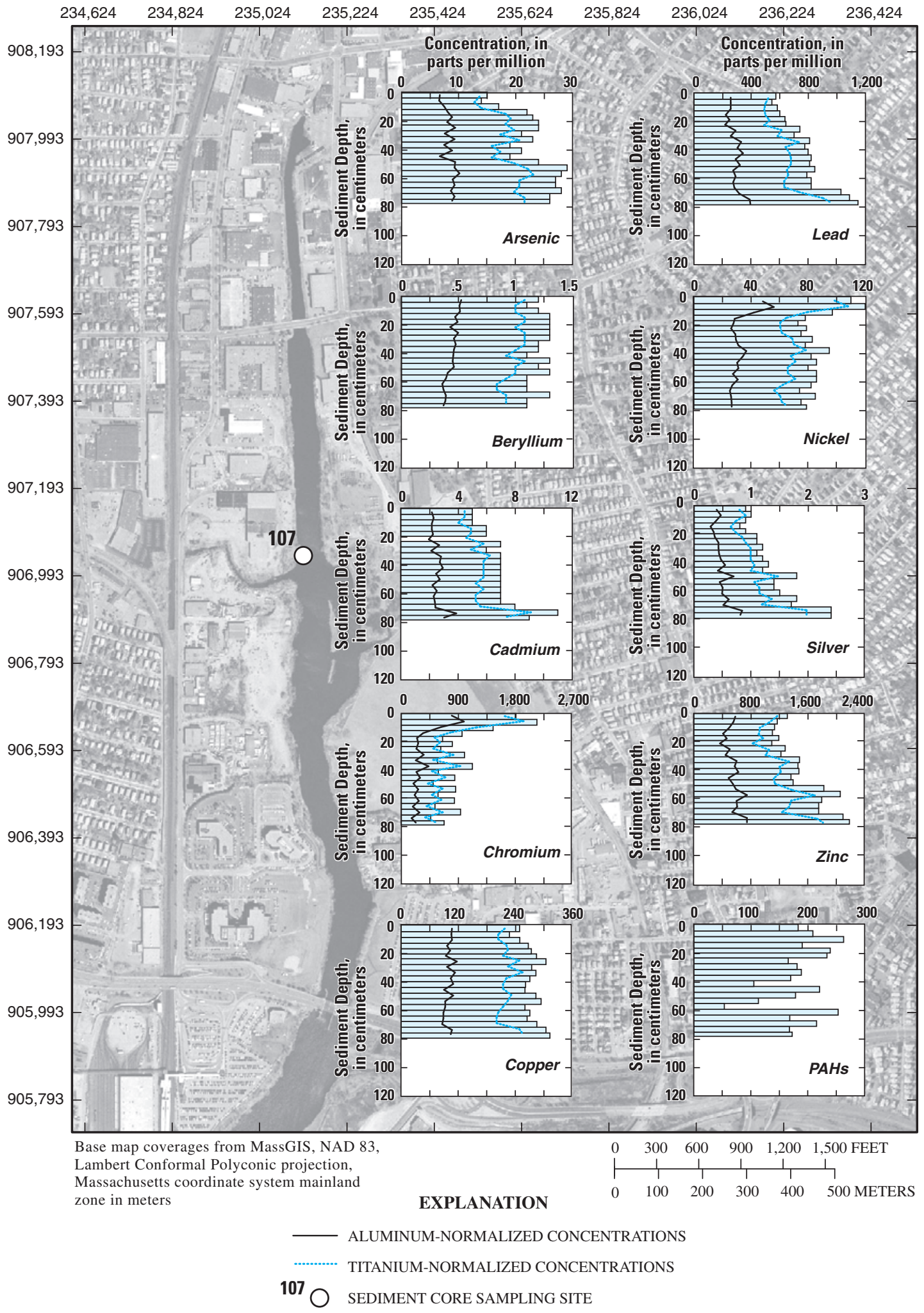

Figure 11. Selected trace element and organic compound concentrations measured in sediment core samples collected from site 107, Malden River, Mystic River Basin, Massachusetts. 


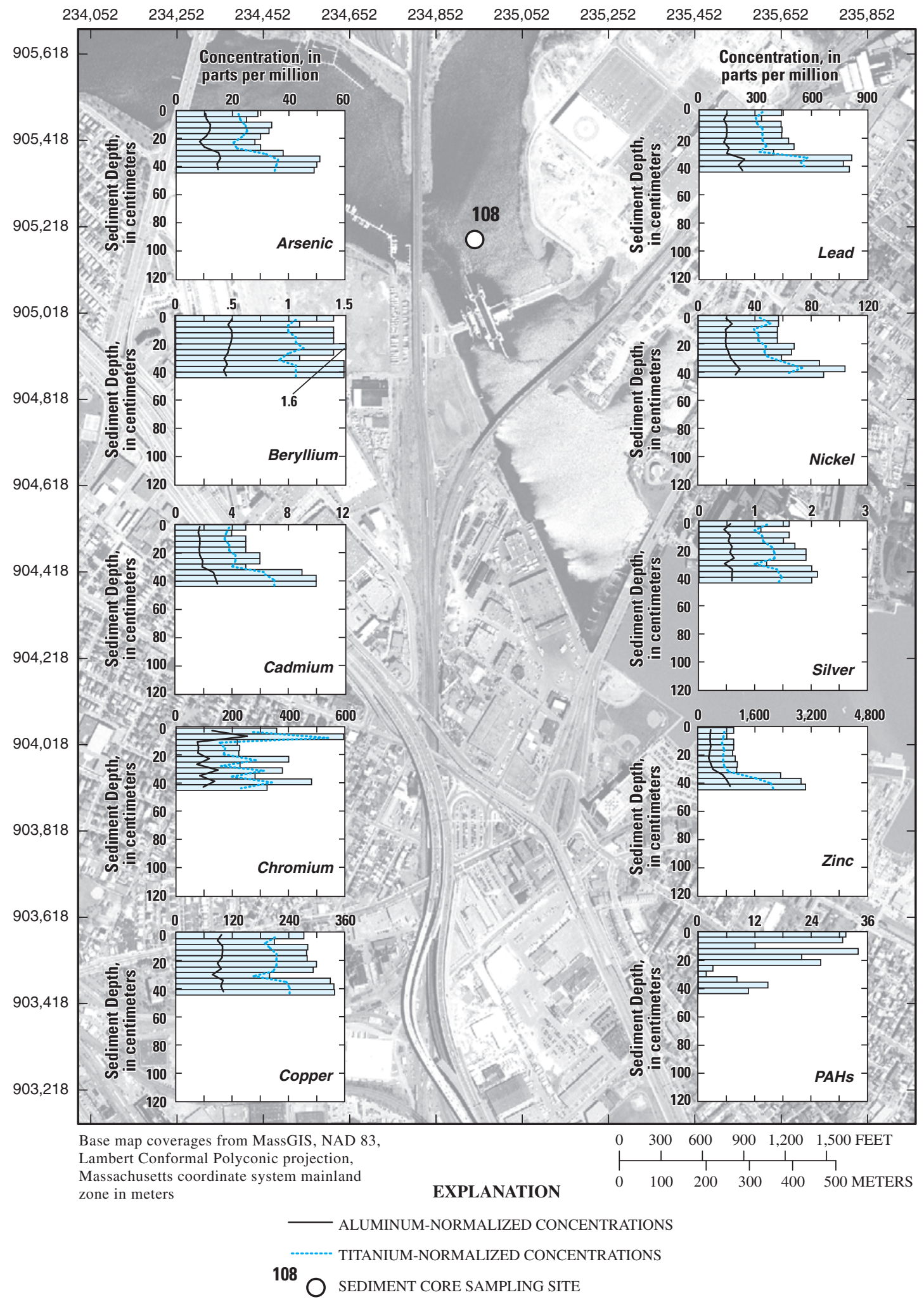

Figure 12. Selected trace element and organic compound concentrations measured in sediment core samples collected from site 108, upper Mystic River about 180 meters above the Amelia Earhart Dam, Mystic River Basin, Massachusetts. 


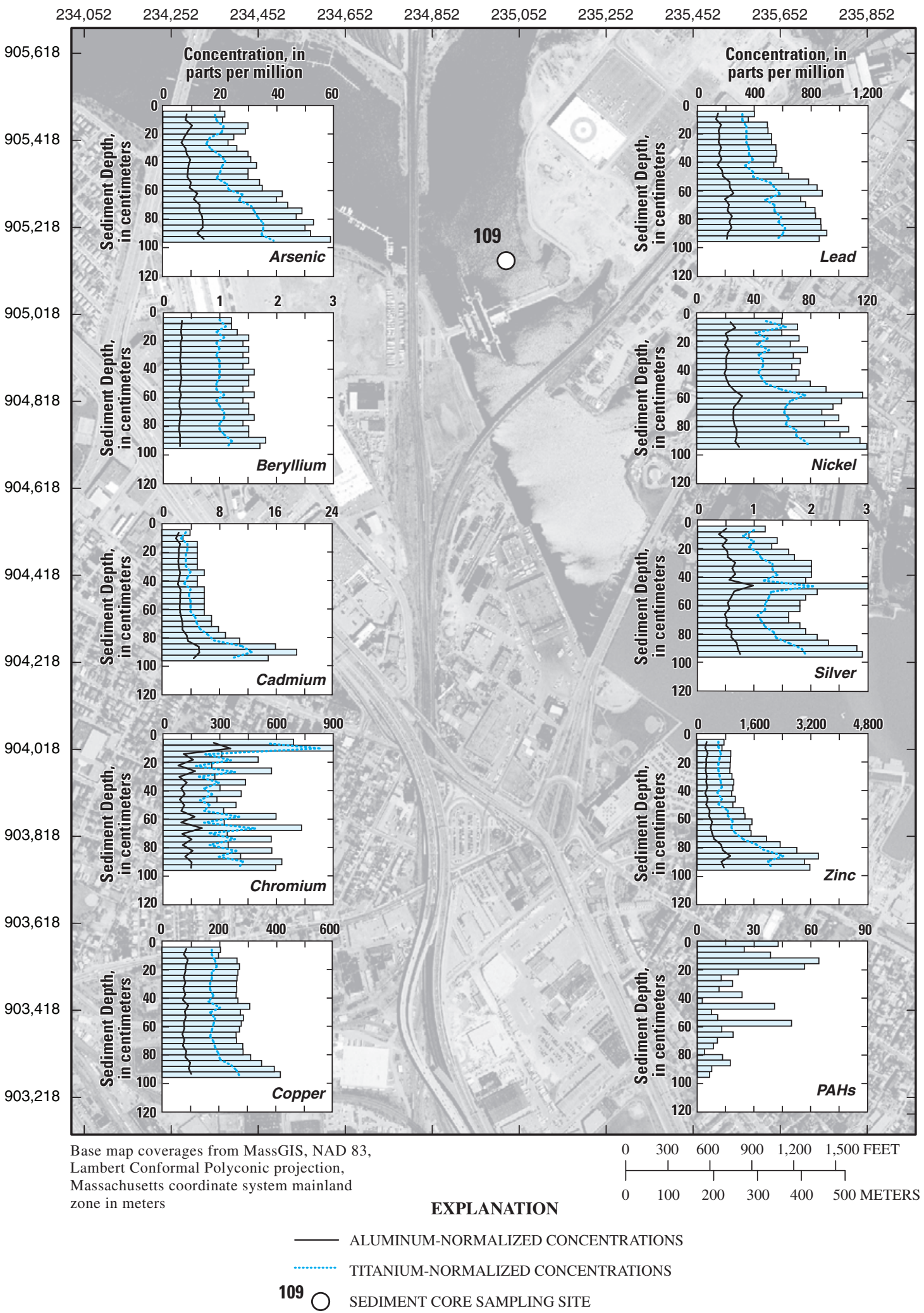

Figure 13. Selected trace element and organic compound concentrations measured in sediment core samples collected from site 109, upper Mystic River about 90 meters above Amelia Earhart Dam, Mystic River Basin, Massachusetts. Data for trace elements were not analyzed for depth range 0-4 centimeters because the entire volume of sediment in this range was needed for organic analysis. 


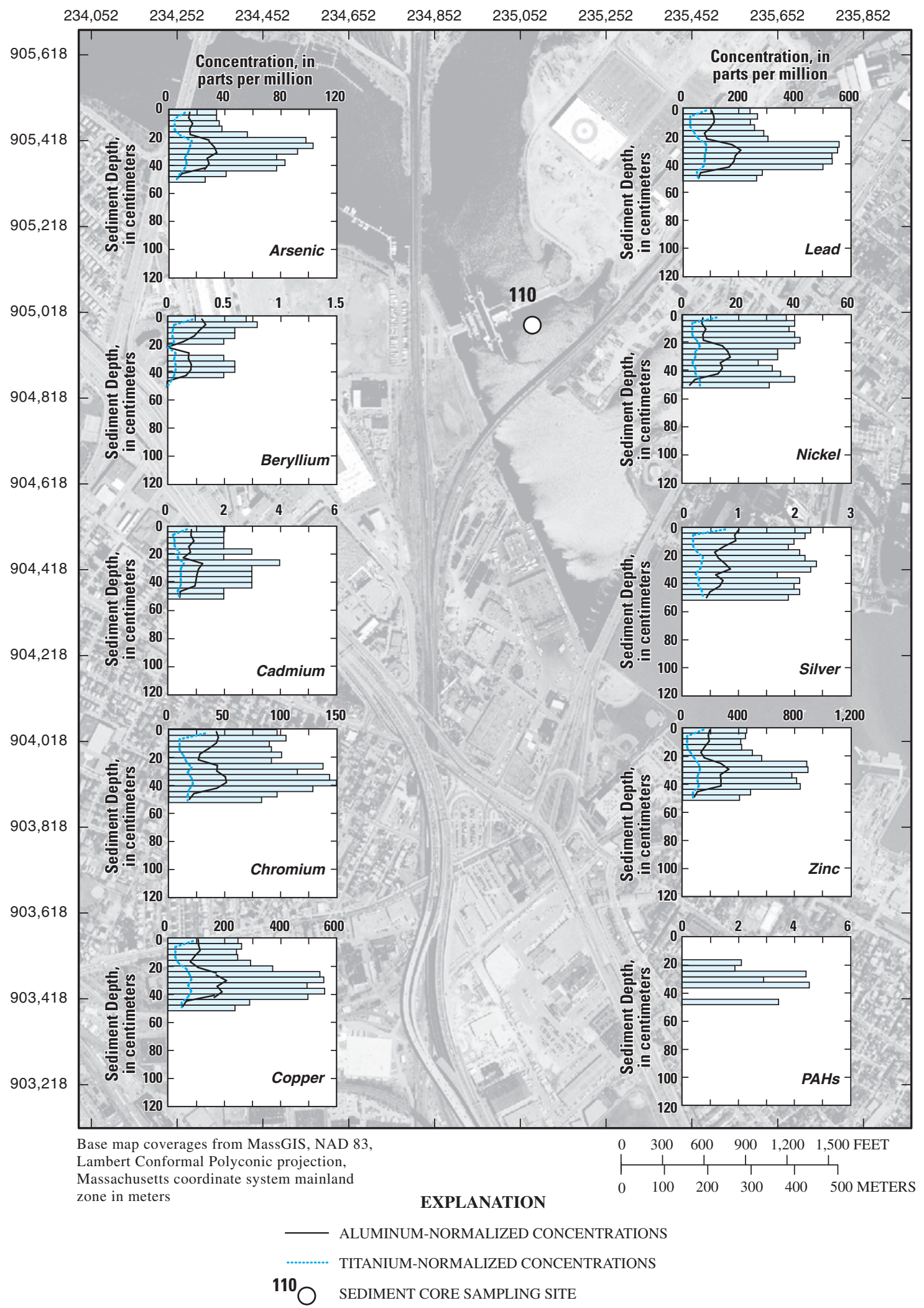

Figure 14. Selected trace element and organic compound concentrations measured in sediment core samples collected from site 110, lower Mystic River about 45 meters below the Amelia Earhart Dam, Mystic River Basin, Massachusetts. 


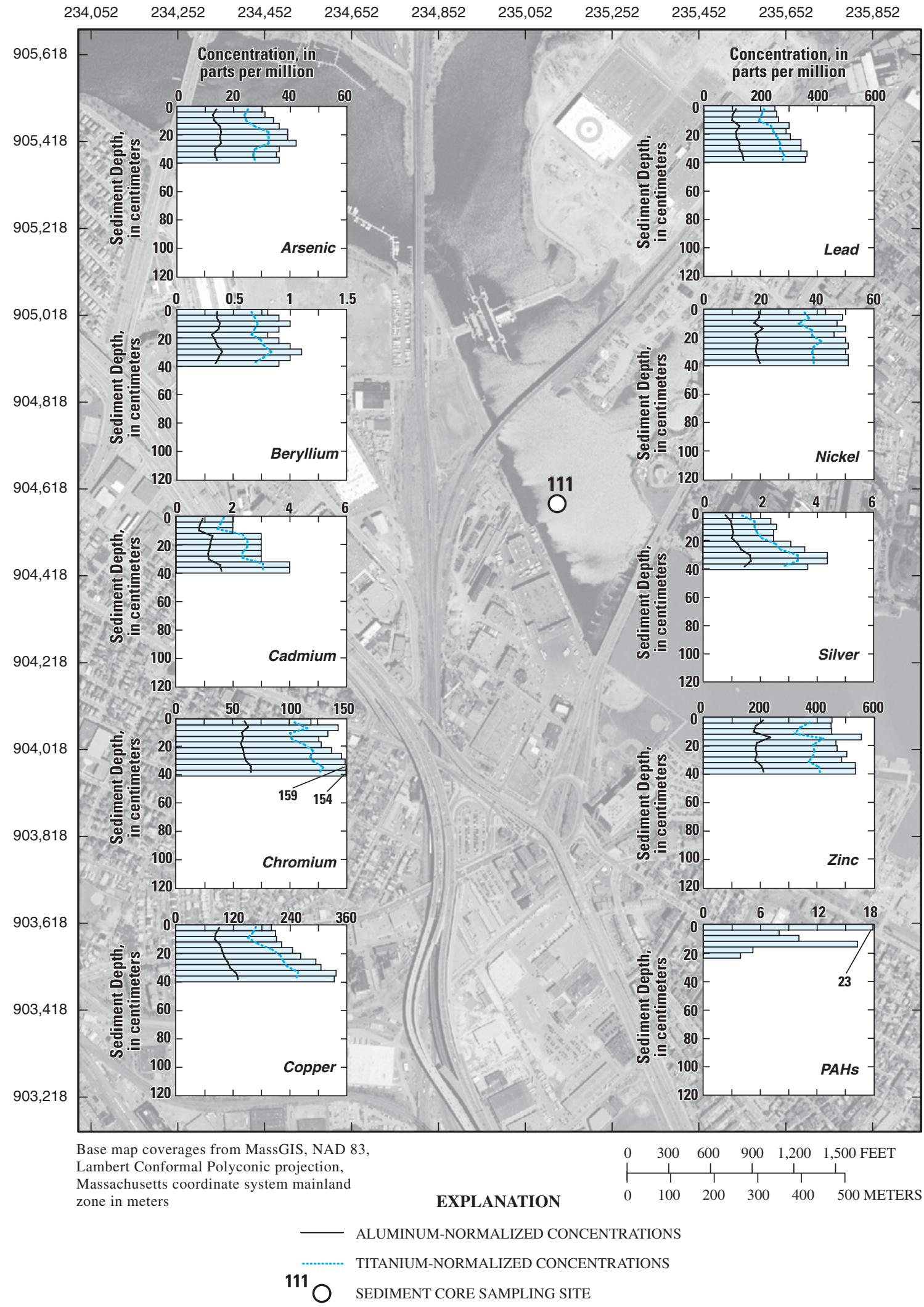

Figure 15. Selected trace element and organic compound concentrations measured in sediment core samples collected from site 111, lower Mystic River about 475 meters below the Amelia Earhart Dam, Mystic River Basin, Massachusetts. 


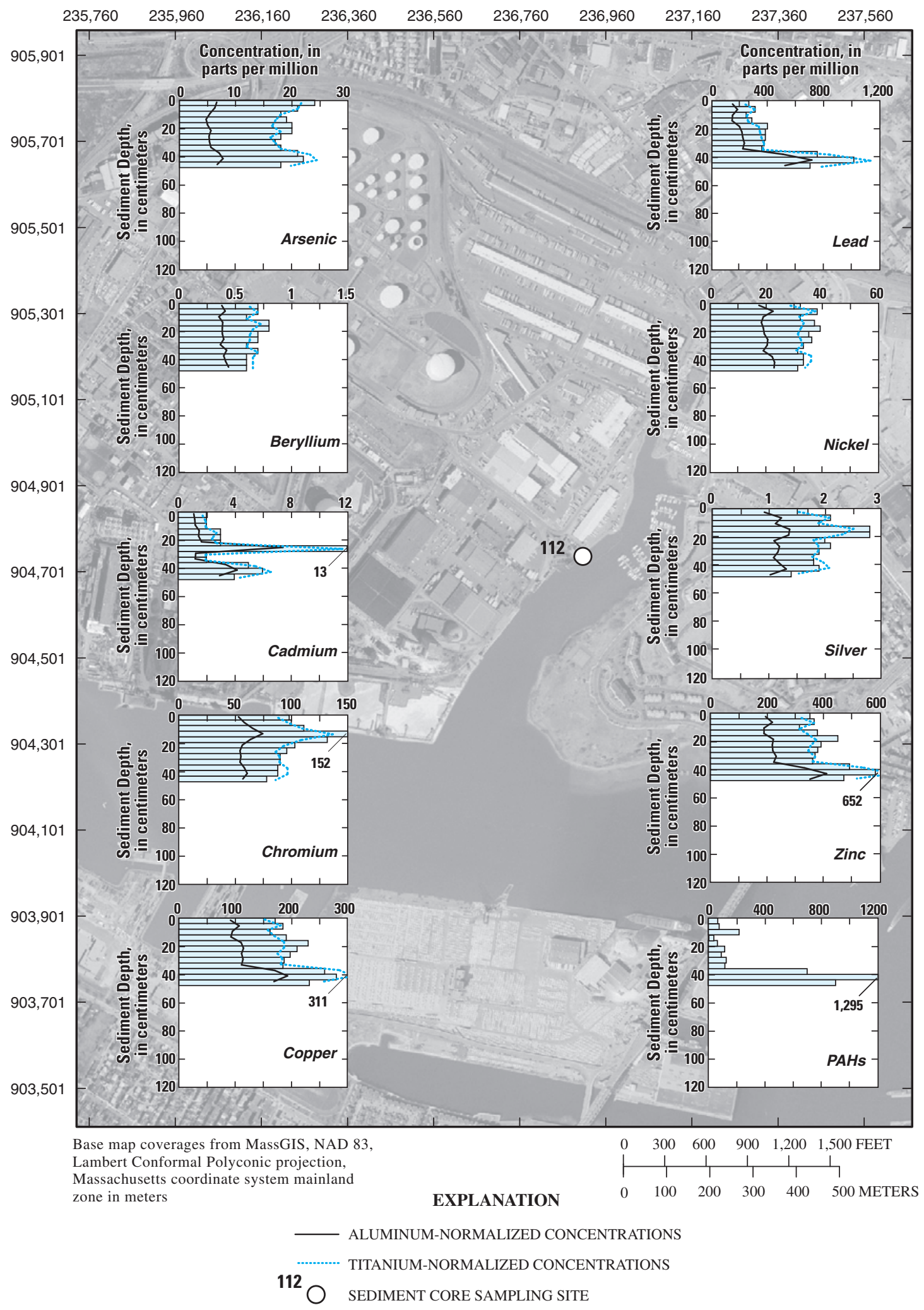

Figure 16. Selected trace element and organic compound concentrations measured in sediment core samples collected from site 112, Island End River, Mystic River Basin, Massachusetts. 


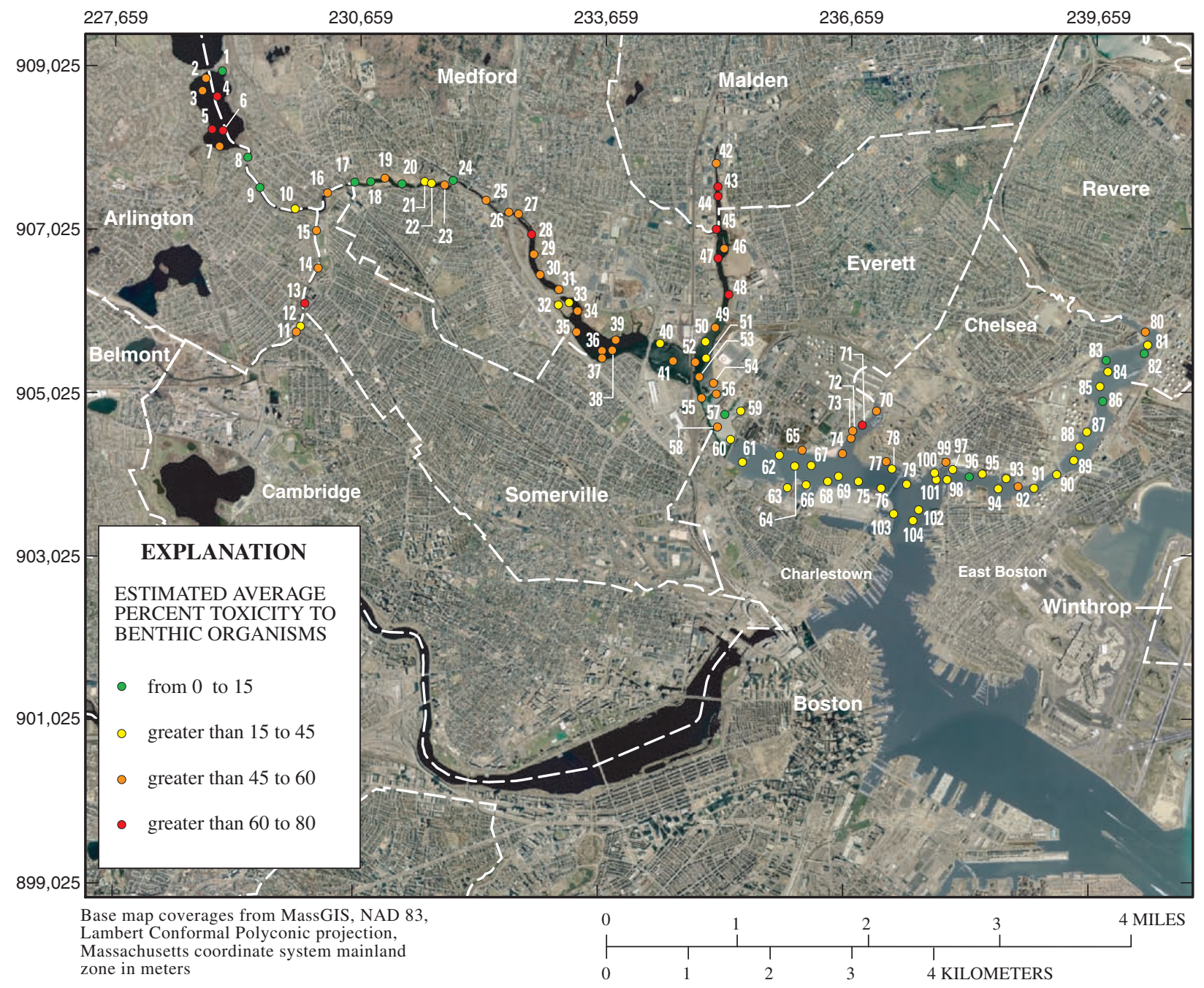

Figure 17. Estimated sediment toxicity to Hyalella azteca and Chiromonus spp. with respect to consensus-based freshwater sediment-quality guidelines. For example, potentitial toxicity of 20 percent means that 20 out of 100 toxicity tests are likely to show some level of toxicity for the concentration of contaminants measured in that sediment sample. 

Tables 3-5 

Table 3. Distribution of element and organic compound concentrations measured in sediment grab samples, Mystic River Basin, Massachusetts.

[Station number: USGS sample identifiers and geographical coordinates are given in table 1; sampling locations shown on figure 3. BHC, 1,2,3,4,5,6-hexachlorocyclohexane; D, duplicate; DDD, dichlorodiphenyldichloroethane; DDE, dichlorodiphenyldichloroethylene; DDT, dichlorodiphenyltrichloroethane; do., ditto; LD, lab duplicate; No., number; PES, Performance Evaluation Standard; RPD, relative percent difference; USGS, U.S. Geological Survey; ppm, parts per million; \%, percent; <, actual value shown is less than the minimum reporting limit; *, PES reported value was less than detection; --, not analyzed]

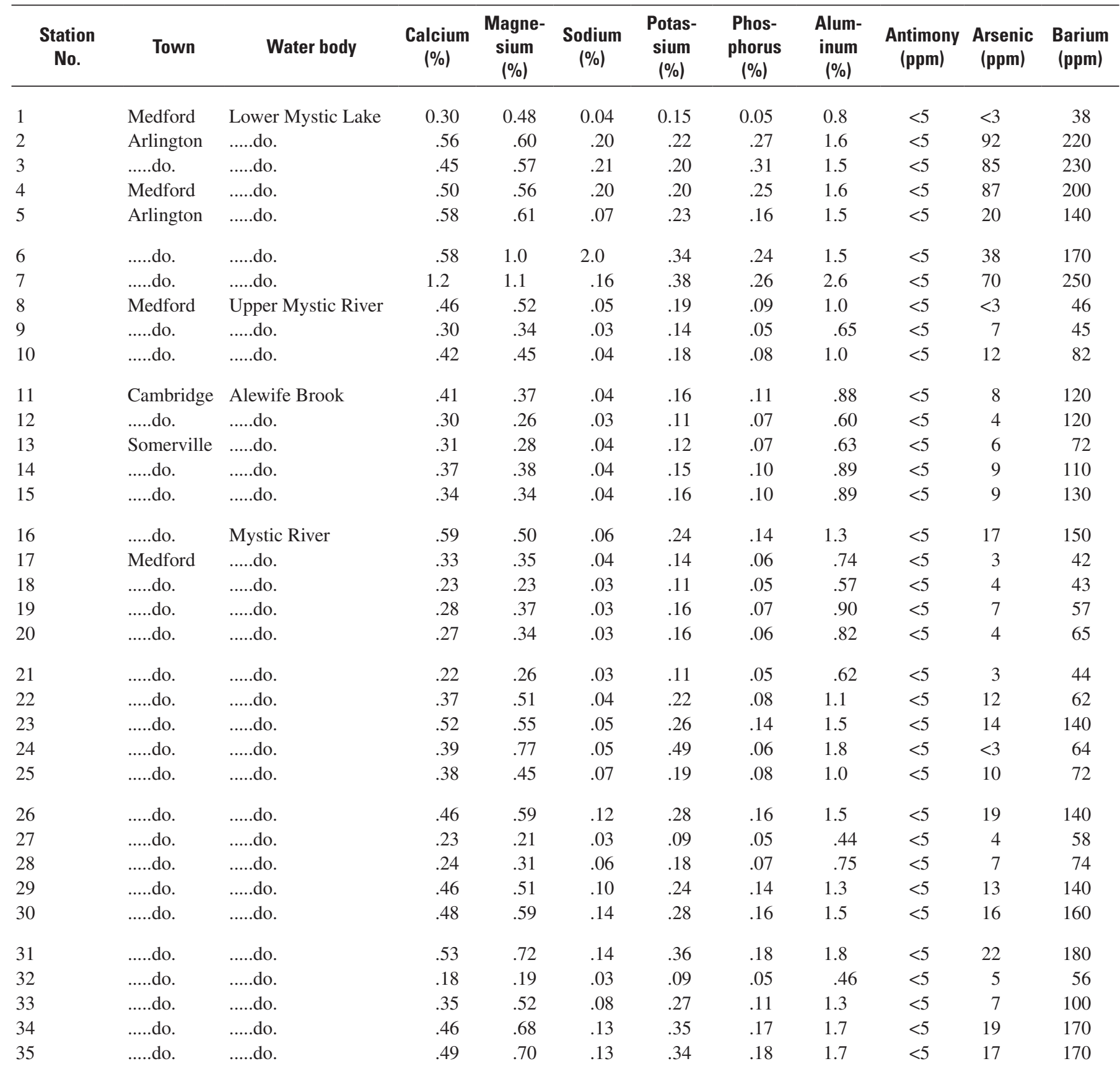


Table 3. Distribution of element and organic compound concentrations measured in sediment grab samples, Mystic River Basin, Massachusetts.-Continued

[Station number: USGS sample identifiers and geographical coordinates are given in table 1; sampling locations shown on figure 3. BHC, 1,2,3,4,5,6-hexachlorocyclohexane; D, duplicate; DDD, dichlorodiphenyldichloroethane; DDE, dichlorodiphenyldichloroethylene; DDT, dichlorodiphenyltrichloroethane; do., ditto; LD, lab duplicate; No., number; PES, Performance Evaluation Standard; RPD, relative percent difference; USGS, U.S. Geological Survey; ppm, parts per million; \%, percent; <, actual value shown is less than the minimum reporting limit; *, PES reported value was less than detection; --, not analyzed]

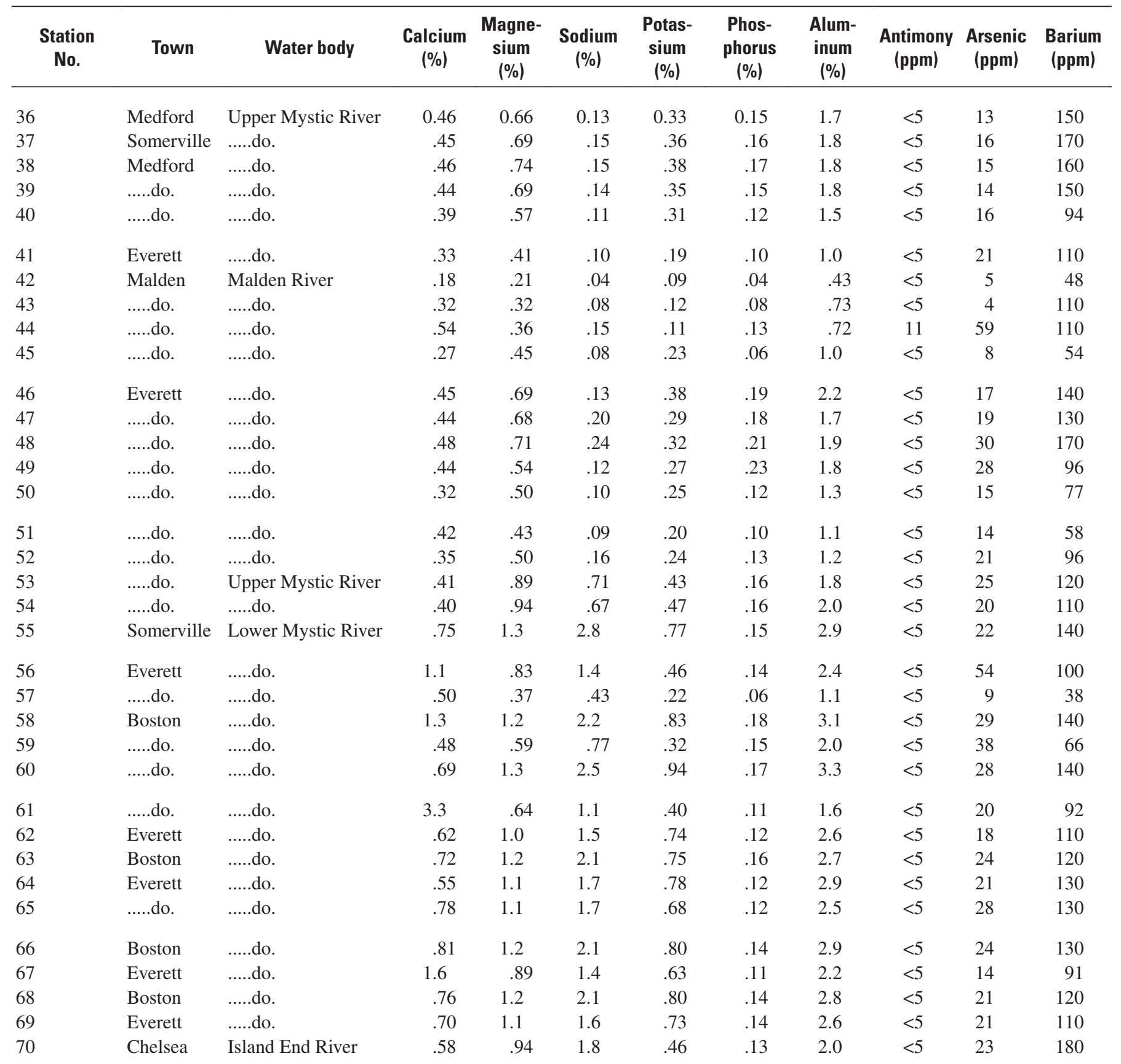


Table 3. Distribution of element and organic compound concentrations measured in sediment grab samples, Mystic River Basin, Massachusetts.-Continued

[Station number: USGS sample identifiers and geographical coordinates are given in table 1; sampling locations shown on figure 3. BHC, 1,2,3,4,5,6-hexachlorocyclohexane; D, duplicate; DDD, dichlorodiphenyldichloroethane; DDE, dichlorodiphenyldichloroethylene; DDT, dichlorodiphenyltrichloroethane; do., ditto; LD, lab duplicate; No., number; PES, Performance Evaluation Standard; RPD, relative percent difference; USGS, U.S. Geological Survey; ppm, parts per million; \%, percent; <, actual value shown is less than the minimum reporting limit; *, PES reported value was less than detection; --, not analyzed]

\begin{tabular}{|c|c|c|c|c|c|c|c|c|c|c|c|}
\hline $\begin{array}{c}\text { Station } \\
\text { No. }\end{array}$ & Town & Water body & $\begin{array}{c}\text { Calcium } \\
(\%)\end{array}$ & $\begin{array}{c}\text { Magne- } \\
\text { sium } \\
(\%)\end{array}$ & $\begin{array}{c}\text { Sodium } \\
(\%)\end{array}$ & $\begin{array}{l}\text { Potas- } \\
\text { sium } \\
(\%)\end{array}$ & $\begin{array}{c}\text { Phos- } \\
\text { phorus } \\
(\%)\end{array}$ & $\begin{array}{c}\text { Alum- } \\
\text { inum } \\
(\%)\end{array}$ & $\begin{array}{c}\text { Antimony } \\
\text { (ppm) }\end{array}$ & $\begin{array}{c}\text { Arsenic } \\
\text { (ppm) }\end{array}$ & $\begin{array}{c}\text { Barium } \\
\text { (ppm) }\end{array}$ \\
\hline 72 & .....do. & ....do. & .61 & 1.0 & 1.8 & .64 & .12 & 2.4 & $<5$ & 20 & 130 \\
\hline 73 & .....do. & .....do. & .36 & .53 & 1.0 & .30 & .07 & 1.2 & $<5$ & 14 & 87 \\
\hline 74 & .....do. & .....do. & .66 & .88 & 1.4 & .53 & .11 & 2.0 & $<5$ & 19 & 98 \\
\hline 76 & .....do. & .....do. & .86 & 1.2 & 1.5 & .78 & .14 & 2.9 & $<5$ & 18 & 120 \\
\hline 77 & Chelsea & .....do. & .59 & .84 & 1.2 & .51 & .11 & 2.1 & $<5$ & 61 & 100 \\
\hline 78 & .....do. & .....do. & .73 & 1.1 & 1.6 & .67 & .15 & 2.5 & $<5$ & 29 & 200 \\
\hline 79 & .....do. & .....do. & .51 & 1.0 & .92 & .67 & .09 & 2.6 & $<5$ & 21 & 100 \\
\hline 80 & .....do. & Mill Creek & 1.7 & .89 & 1.3 & .52 & .14 & 2.5 & $<5$ & 16 & 160 \\
\hline 84 & .....do. & .....do. & .51 & .89 & 1.1 & .62 & .09 & 2.4 & $<5$ & 10 & 100 \\
\hline 85 & .....do. & .....do. & .53 & .81 & 1.2 & .55 & .11 & 2.2 & $<5$ & 12 & 110 \\
\hline 86 & Boston & .....do. & .42 & .50 & .57 & .29 & .06 & 1.3 & $<5$ & 9 & 57 \\
\hline 87 & Chelsea & .....do. & .62 & .86 & 1.4 & .56 & .11 & 2.2 & $<5$ & 11 & 100 \\
\hline 88 & .....do. & .....do. & 1.4 & 1.0 & 1.4 & .58 & .14 & 2.3 & $<5$ & 17 & 94 \\
\hline 89 & Boston & .....do. & .66 & .60 & .74 & .35 & .08 & 1.5 & $<5$ & 8 & 66 \\
\hline 90 & .....do. & .....do. & .58 & .64 & .75 & .36 & .08 & 1.6 & $<5$ & 9 & 71 \\
\hline 91 & .....do. & .....do. & .56 & .80 & 1.1 & .49 & .10 & 2.1 & $<5$ & 11 & 85 \\
\hline 92 & Chelsea & .....do. & .56 & .91 & .78 & .44 & .11 & 2.1 & $<5$ & 11 & 92 \\
\hline 93 & .....do. & .....do. & .57 & .87 & .90 & .55 & .12 & 2.3 & $<5$ & 17 & 110 \\
\hline 100 & .....do. & ......do. & .60 & .73 & .88 & .49 & .09 & 2.0 & $<5$ & 12 & 86 \\
\hline 101 & Boston & .....do. & .60 & .77 & 1.0 & .49 & .10 & 1.9 & $<5$ & 13 & 77 \\
\hline 102 & .....do. & Boston Inner Harbor & .66 & 1.1 & 1.5 & .71 & .15 & 2.7 & $<5$ & 19 & 100 \\
\hline 103 & .....do. & .....do. & .71 & 1.1 & 1.4 & .75 & .14 & 2.8 & $<5$ & 23 & 130 \\
\hline 104 & .....do. & .....do. & .48 & .82 & 1.0 & .53 & .08 & 2.1 & $<5$ & 24 & 99 \\
\hline
\end{tabular}


Table 3. Distribution of element and organic compound concentrations measured in sediment grab samples, Mystic River Basin, Massachusetts.-Continued

[Station number: USGS sample identifiers and geographical coordinates are given in table 1; sampling locations shown on figure 3. BHC, 1,2,3,4,5,6-hexachlorocyclohexane; D, duplicate; DDD, dichlorodiphenyldichloroethane; DDE, dichlorodiphenyldichloroethylene; DDT, dichlorodiphenyltrichloroethane; do., ditto; LD, lab duplicate; No., number; PES, Performance Evaluation Standard; RPD, relative percent difference; USGS, U.S. Geological Survey; ppm, parts per million; \%, percent; <, actual value shown is less than the minimum reporting limit; *, PES reported value was less than detection; --, not analyzed]

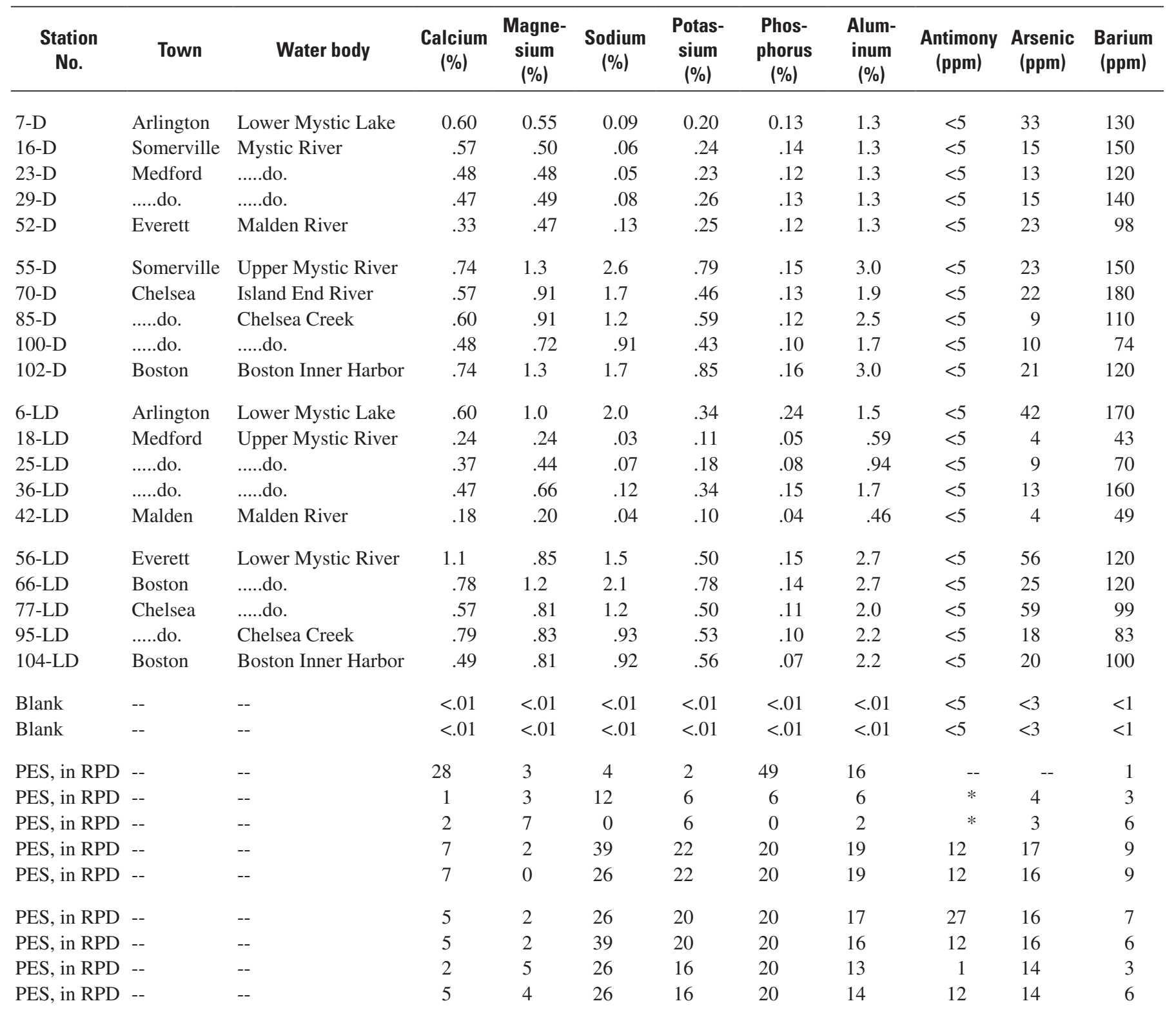


Table 3. Distribution of element and organic compound concentrations measured in sediment grab samples, Mystic River Basin, Massachusetts.-Continued

[Station number: USGS sample identifiers and geographical coordinates are given in table 1; sampling locations shown on figure 3. BHC, 1,2,3,4,5,6-hexachlorocyclohexane; D, duplicate; DDD, dichlorodiphenyldichloroethane; DDE, dichlorodiphenyldichloroethylene; DDT, dichlorodiphenyltrichloroethane; do., ditto; LD, lab duplicate; No., number; PES, Performance Evaluation Standard; RPD, relative percent difference; USGS, U.S. Geological Survey; ppm, parts per million; \%, percent; <, actual value shown is less than the minimum reporting limit; *, PES reported value was less than detection; --, not analyzed]

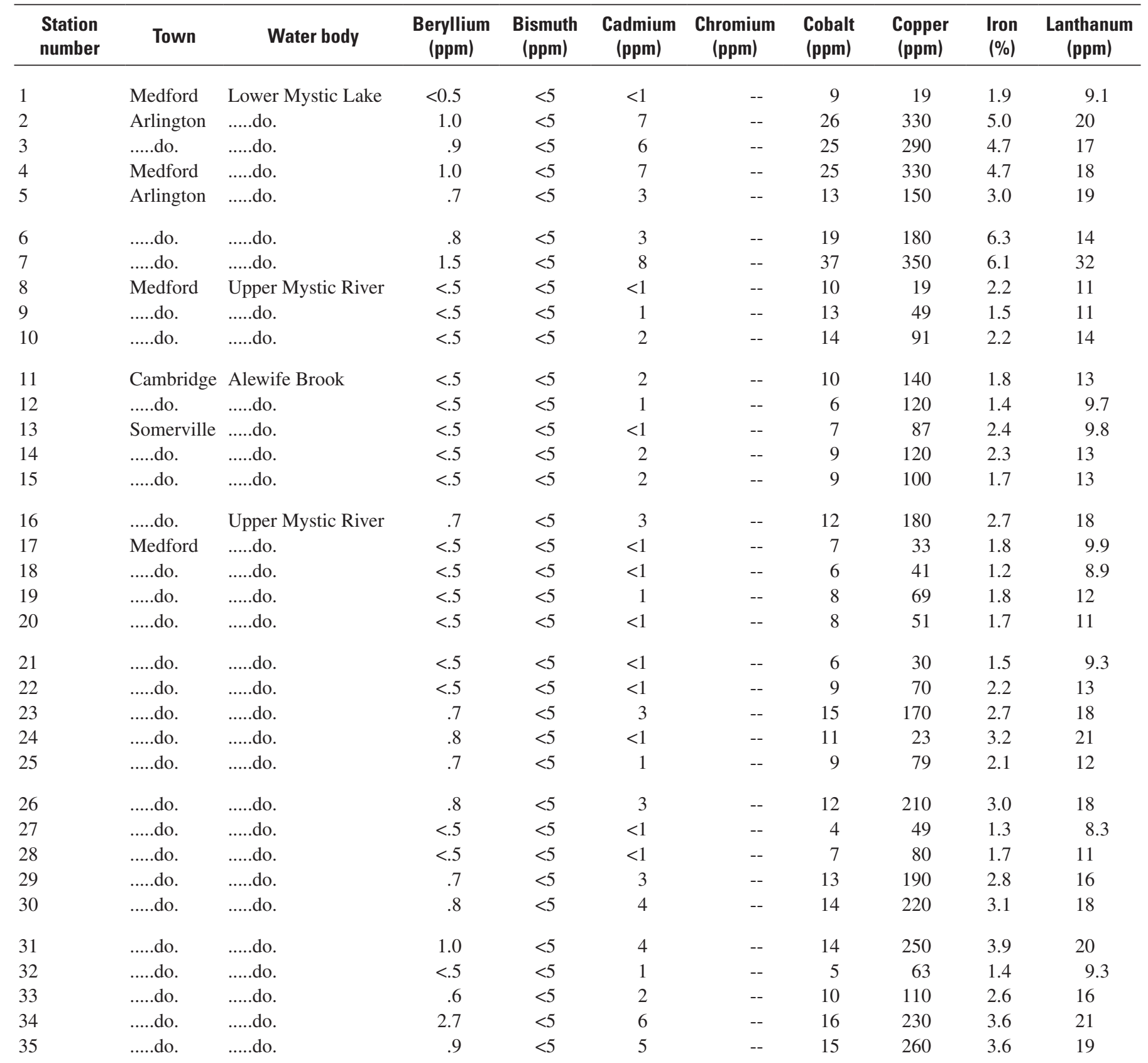


Table 3. Distribution of element and organic compound concentrations measured in sediment grab samples, Mystic River Basin, Massachusetts.-Continued

[Station number: USGS sample identifiers and geographical coordinates are given in table 1; sampling locations shown on figure 3. BHC, 1,2,3,4,5,6-hexachlorocyclohexane; D, duplicate; DDD, dichlorodiphenyldichloroethane; DDE, dichlorodiphenyldichloroethylene; DDT, dichlorodiphenyltrichloroethane; do., ditto; LD, lab duplicate; No., number; PES, Performance Evaluation Standard; RPD, relative percent difference; USGS, U.S. Geological Survey; ppm, parts per million; \%, percent; <, actual value shown is less than the minimum reporting limit; *, PES reported value was less than detection; --, not analyzed]

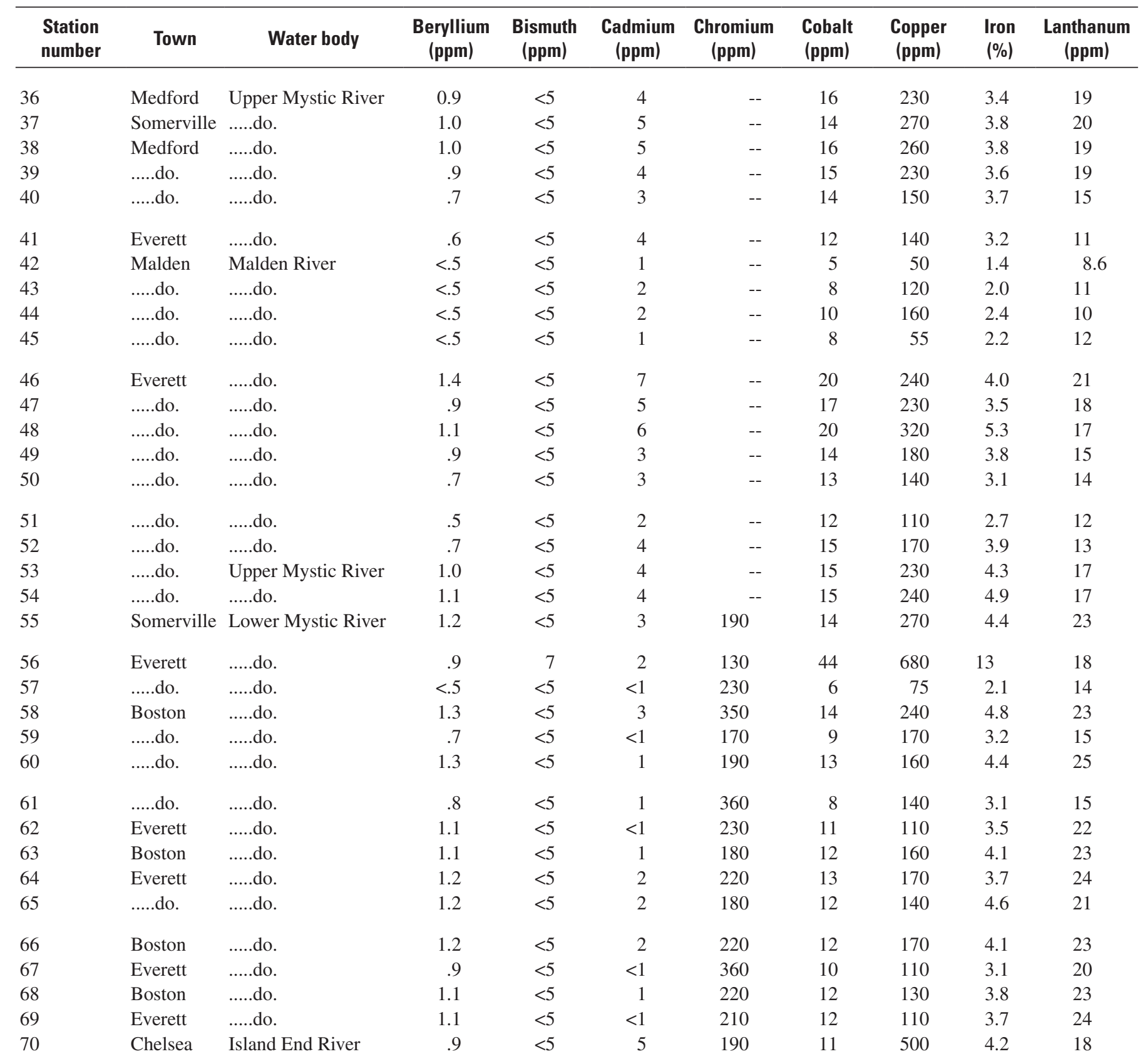


Table 3. Distribution of element and organic compound concentrations measured in sediment grab samples, Mystic River Basin, Massachusetts.-Continued

[Station number: USGS sample identifiers and geographical coordinates are given in table 1; sampling locations shown on figure 3. BHC, 1,2,3,4,5,6-hexachlorocyclohexane; D, duplicate; DDD, dichlorodiphenyldichloroethane; DDE, dichlorodiphenyldichloroethylene; DDT, dichlorodiphenyltrichloroethane; do., ditto; LD, lab duplicate; No., number; PES, Performance Evaluation Standard; RPD, relative percent difference; USGS, U.S. Geological Survey; ppm, parts per million; \%, percent; <, actual value shown is less than the minimum reporting limit; *, PES reported value was less than detection; --, not analyzed]

\begin{tabular}{|c|c|c|c|c|c|c|c|c|c|c|}
\hline $\begin{array}{l}\text { Station } \\
\text { number }\end{array}$ & Town & Water body & $\begin{array}{l}\text { Beryllium } \\
\text { (ppm) }\end{array}$ & $\begin{array}{c}\text { Bismuth } \\
\text { (ppm) }\end{array}$ & $\begin{array}{c}\text { Cadmium } \\
\text { (ppm) }\end{array}$ & $\begin{array}{l}\text { Chromium } \\
\quad \text { (ppm) }\end{array}$ & $\begin{array}{l}\text { Cobalt } \\
\text { (ppm) }\end{array}$ & $\begin{array}{c}\text { Copper } \\
\text { (ppm) }\end{array}$ & $\begin{array}{l}\text { Iron } \\
(\%)\end{array}$ & $\begin{array}{l}\text { Lanthanum } \\
\text { (ppm) }\end{array}$ \\
\hline 71 & Everett & Island End River & 1.1 & $<5$ & 3 & 180 & 11 & 260 & 3.6 & 22 \\
\hline 73 & .....do. & .....do. & 1.1 & $<5$ & 1 & 110 & 8 & 110 & 2.1 & 12 \\
\hline 74 & .....do. & .....do. & 1.0 & $<5$ & 2 & 170 & 10 & 140 & 3.1 & 19 \\
\hline 77 & Chelsea & .....do. & 1.2 & $<5$ & 1 & 160 & 10 & 150 & 3.3 & 20 \\
\hline 78 & .....do. & .....do. & 1.1 & $<5$ & $<1$ & 170 & 12 & 120 & 3.7 & 23 \\
\hline 79 & .....do. & .....do. & 1.0 & $<5$ & $<1$ & 160 & 12 & 82 & 3.4 & 24 \\
\hline 80 & .....do. & Mill Creek & 1.2 & $<5$ & 2 & 170 & 10 & 180 & 3.5 & 21 \\
\hline 85 & .....do. & .....do. & .9 & $<5$ & $<1$ & 340 & 10 & 77 & 2.9 & 19 \\
\hline 86 & Boston & .....do. & .6 & $<5$ & $<1$ & 220 & 6 & 56 & 1.9 & 15 \\
\hline 87 & Chelsea & .....do. & .9 & $<5$ & $<1$ & 390 & 9 & 93 & 3.0 & 20 \\
\hline 88 & .....do. & .....do. & 1.0 & $<5$ & $<1$ & 210 & 10 & 100 & 3.2 & 20 \\
\hline 89 & Boston & .....do. & .6 & $<5$ & $<1$ & 290 & 7 & 78 & 2.3 & 15 \\
\hline 90 & .....do. & .....do. & .7 & $<5$ & $<1$ & 250 & 8 & 82 & 2.4 & 16 \\
\hline 91 & .....do. & .....do. & .8 & $<5$ & $<1$ & 240 & 9 & 84 & 3.0 & 19 \\
\hline 92 & Chelsea & .....do. & .8 & $<5$ & $<1$ & 180 & 12 & 67 & 3.3 & 18 \\
\hline 93 & .....do. & .....do. & 1.0 & $<5$ & 1 & 230 & 10 & 120 & 3.3 & 22 \\
\hline 101 & Boston & .....do. & .8 & $<5$ & $<1$ & 160 & 9 & 80 & 2.8 & 19 \\
\hline 102 & .....do. & Boston Inner Harbor & 1.1 & $<5$ & $<1$ & 190 & 12 & 120 & 3.8 & 25 \\
\hline 103 & .....do. & .....do. & 1.2 & $<5$ & 1 & 210 & 12 & 150 & 3.9 & 25 \\
\hline 104 & .....do. & .....do. & .9 & $<5$ & 1 & 210 & 10 & 120 & 3.0 & 20 \\
\hline
\end{tabular}


Table 3. Distribution of element and organic compound concentrations measured in sediment grab samples, Mystic River Basin, Massachusetts.-Continued

[Station number: USGS sample identifiers and geographical coordinates are given in table 1; sampling locations shown on figure 3. BHC, 1,2,3,4,5,6-hexachlorocyclohexane; D, duplicate; DDD, dichlorodiphenyldichloroethane; DDE, dichlorodiphenyldichloroethylene; DDT, dichlorodiphenyltrichloroethane; do., ditto; LD, lab duplicate; No., number; PES, Performance Evaluation Standard; RPD, relative percent difference; USGS, U.S. Geological Survey; ppm, parts per million; \%, percent; <, actual value shown is less than the minimum reporting limit; *, PES reported value was less than detection; --, not analyzed]

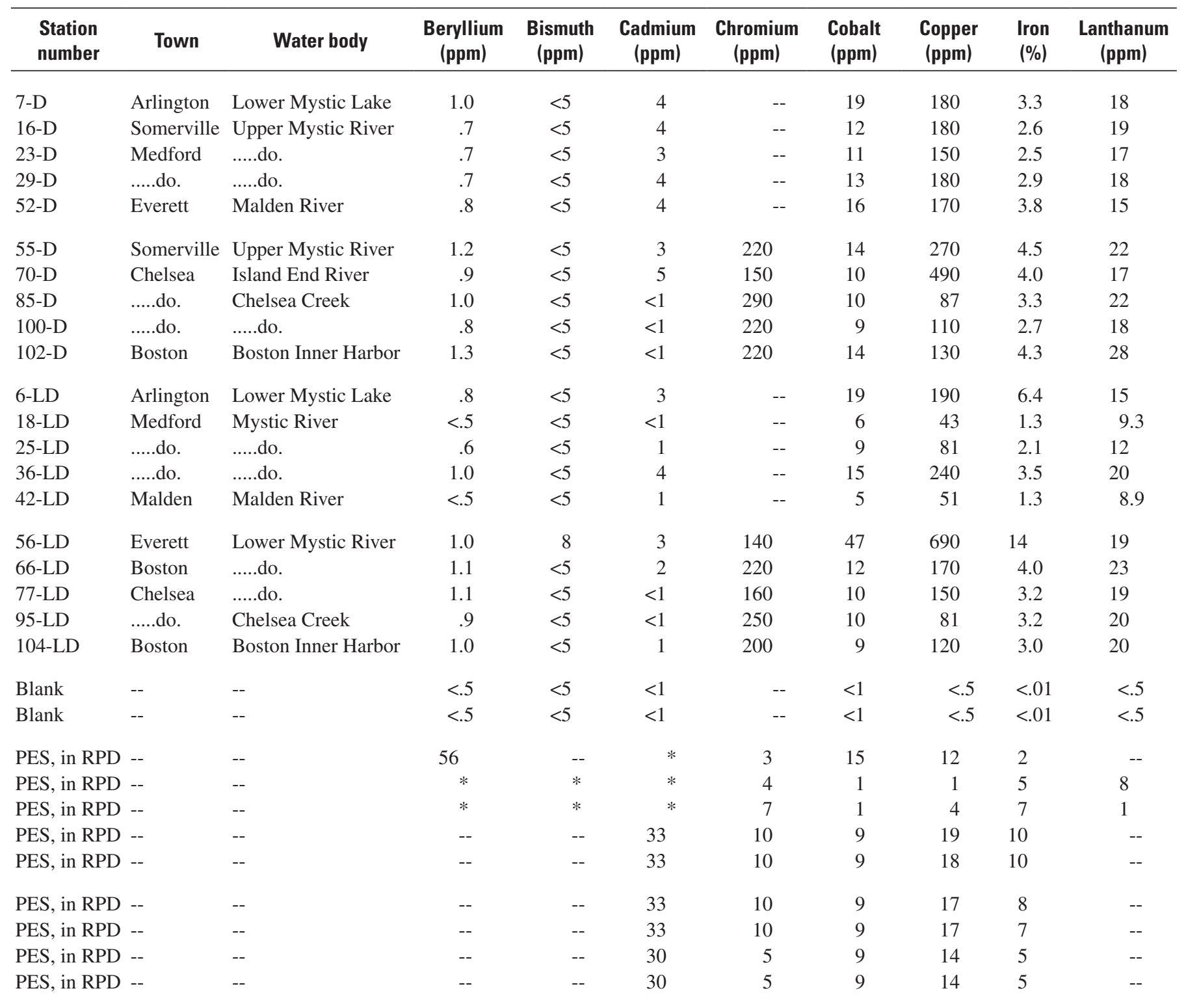


Table 3. Distribution of element and organic compound concentrations measured in sediment grab samples, Mystic River Basin, Massachusetts.-Continued

[Station number: USGS sample identifiers and geographical coordinates are given in table 1; sampling locations shown on figure 3. BHC, 1,2,3,4,5,6-hexachlorocyclohexane; D, duplicate; DDD, dichlorodiphenyldichloroethane; DDE, dichlorodiphenyldichloroethylene; DDT, dichlorodiphenyltrichloroethane; do., ditto; LD, lab duplicate; No., number; PES, Performance Evaluation Standard; RPD, relative percent difference; USGS, U.S. Geological Survey; ppm, parts per million; \%, percent; <, actual value shown is less than the minimum reporting limit; *, PES reported value was less than detection; --, not analyzed]

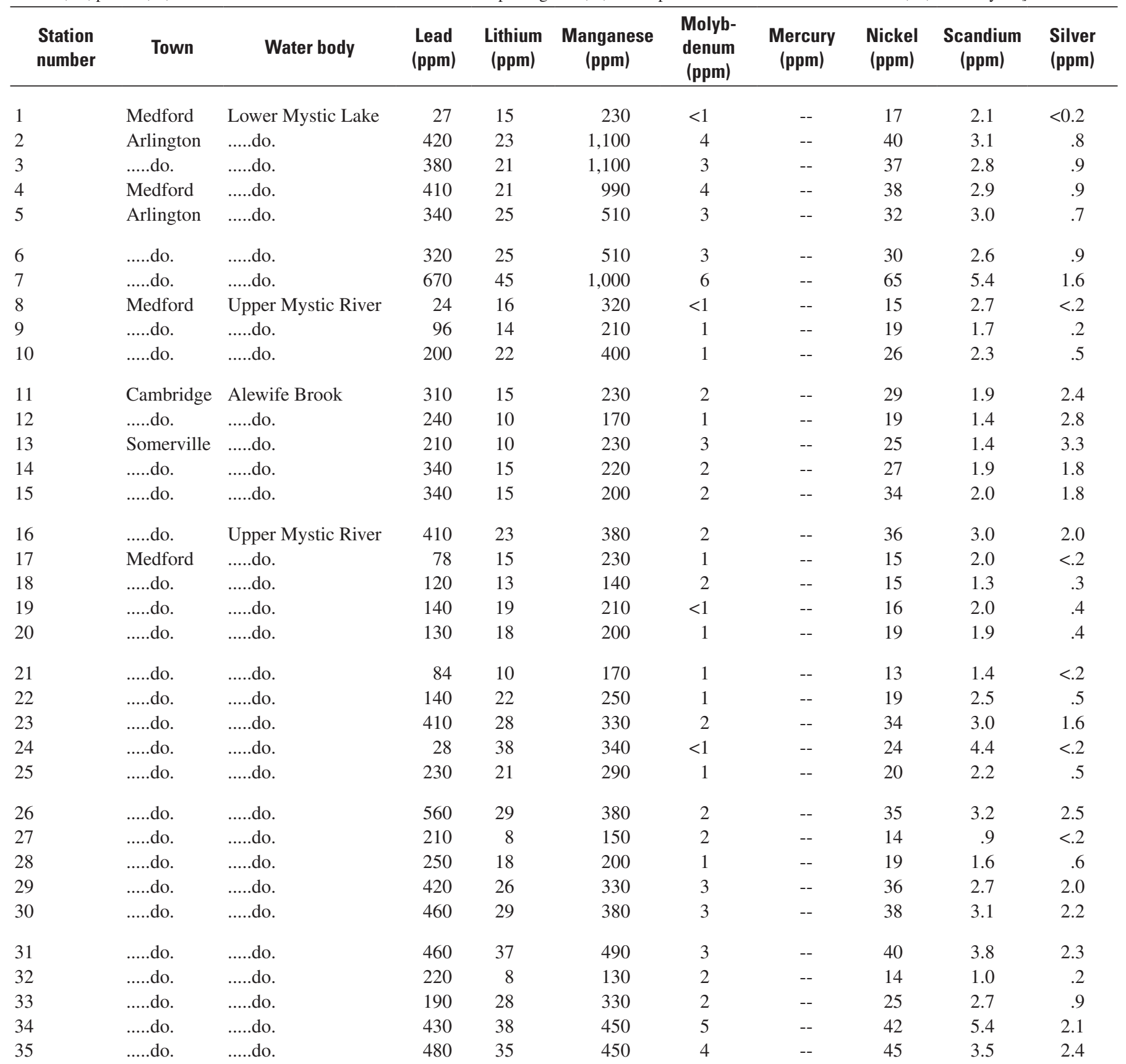


Table 3. Distribution of element and organic compound concentrations measured in sediment grab samples, Mystic River Basin, Massachusetts.-Continued

[Station number: USGS sample identifiers and geographical coordinates are given in table 1; sampling locations shown on figure 3. BHC, 1,2,3,4,5,6-hexachlorocyclohexane; D, duplicate; DDD, dichlorodiphenyldichloroethane; DDE, dichlorodiphenyldichloroethylene; DDT, dichlorodiphenyltrichloroethane; do., ditto; LD, lab duplicate; No., number; PES, Performance Evaluation Standard; RPD, relative percent difference; USGS, U.S. Geological Survey; ppm, parts per million; \%, percent; <, actual value shown is less than the minimum reporting limit; *, PES reported value was less than detection; --, not analyzed]

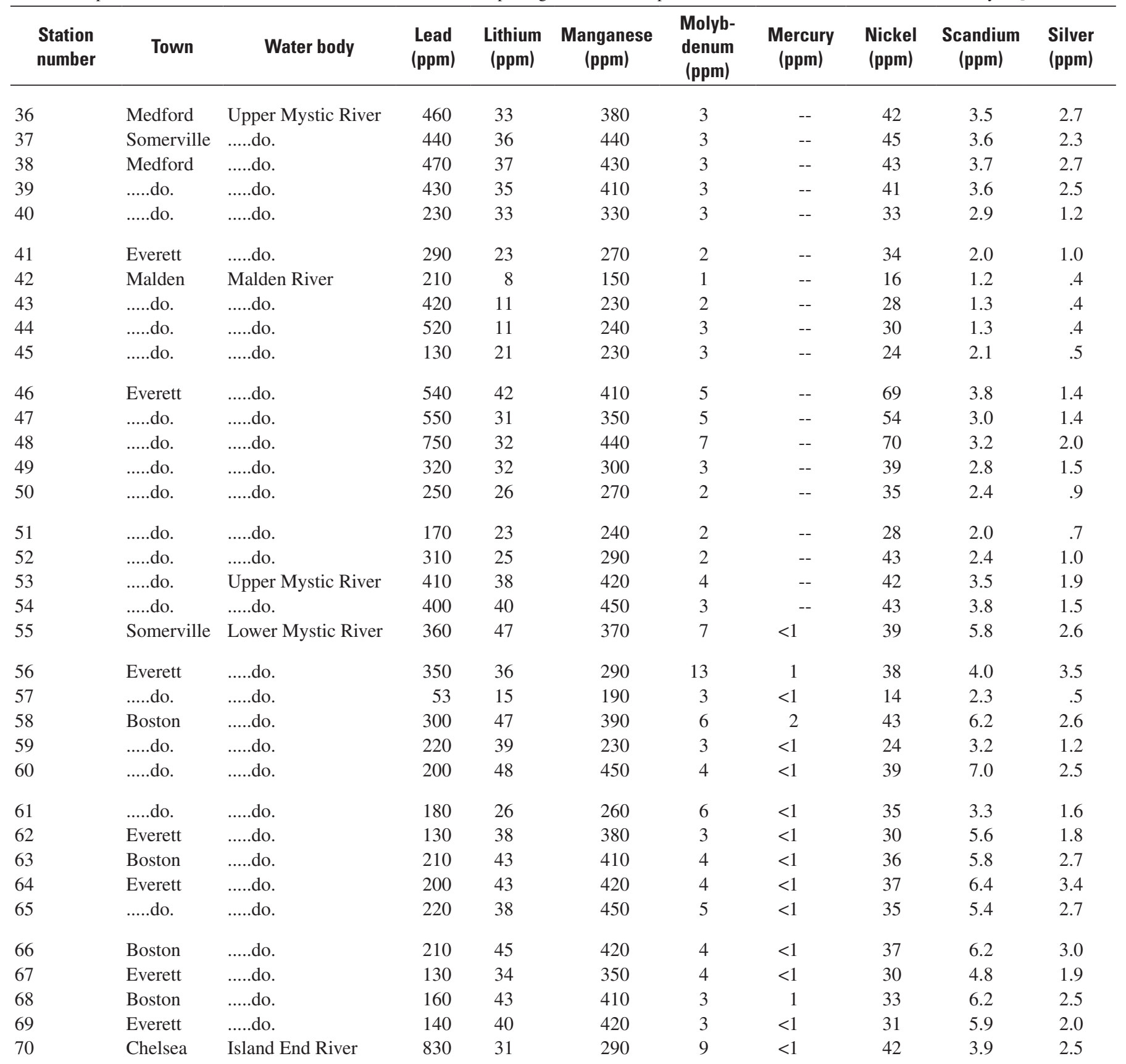


Table 3. Distribution of element and organic compound concentrations measured in sediment grab samples, Mystic River Basin, Massachusetts.-Continued

[Station number: USGS sample identifiers and geographical coordinates are given in table 1; sampling locations shown on figure 3. BHC, 1,2,3,4,5,6-hexachlorocyclohexane; D, duplicate; DDD, dichlorodiphenyldichloroethane; DDE, dichlorodiphenyldichloroethylene; DDT, dichlorodiphenyltrichloroethane; do., ditto; LD, lab duplicate; No., number; PES, Performance Evaluation Standard; RPD, relative percent difference; USGS, U.S. Geological Survey; ppm, parts per million; \%, percent; <, actual value shown is less than the minimum reporting limit; *, PES reported value was less than detection; --, not analyzed]

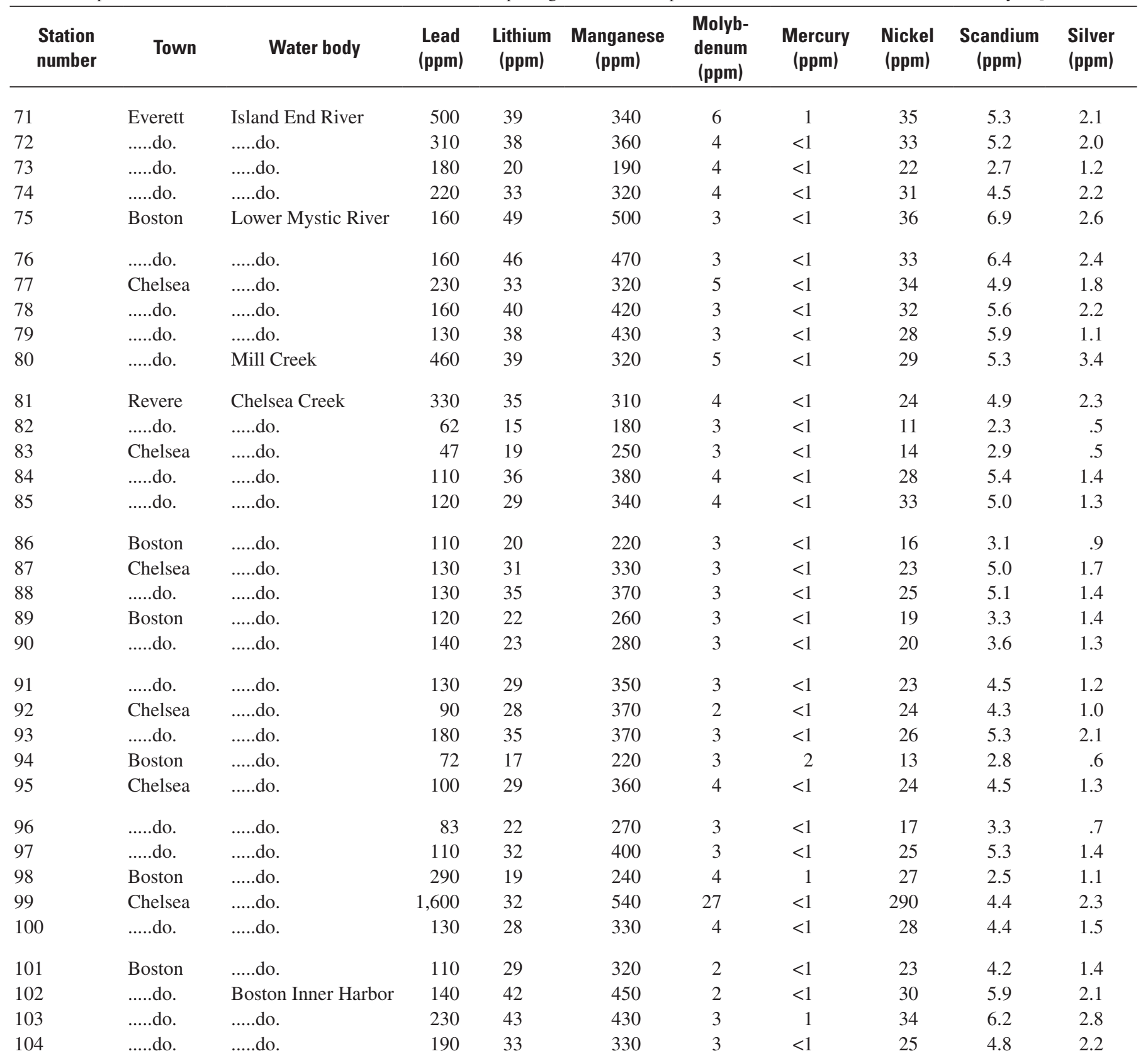


Table 3. Distribution of element and organic compound concentrations measured in sediment grab samples, Mystic River Basin, Massachusetts.-Continued

[Station number: USGS sample identifiers and geographical coordinates are given in table 1; sampling locations shown on figure 3. BHC, 1,2,3,4,5,6-hexachlorocyclohexane; D, duplicate; DDD, dichlorodiphenyldichloroethane; DDE, dichlorodiphenyldichloroethylene; DDT, dichlorodiphenyltrichloroethane; do., ditto; LD, lab duplicate; No., number; PES, Performance Evaluation Standard; RPD, relative percent difference; USGS, U.S. Geological Survey; ppm, parts per million; \%, percent; <, actual value shown is less than the minimum reporting limit; *, PES reported value was less than detection; --, not analyzed]

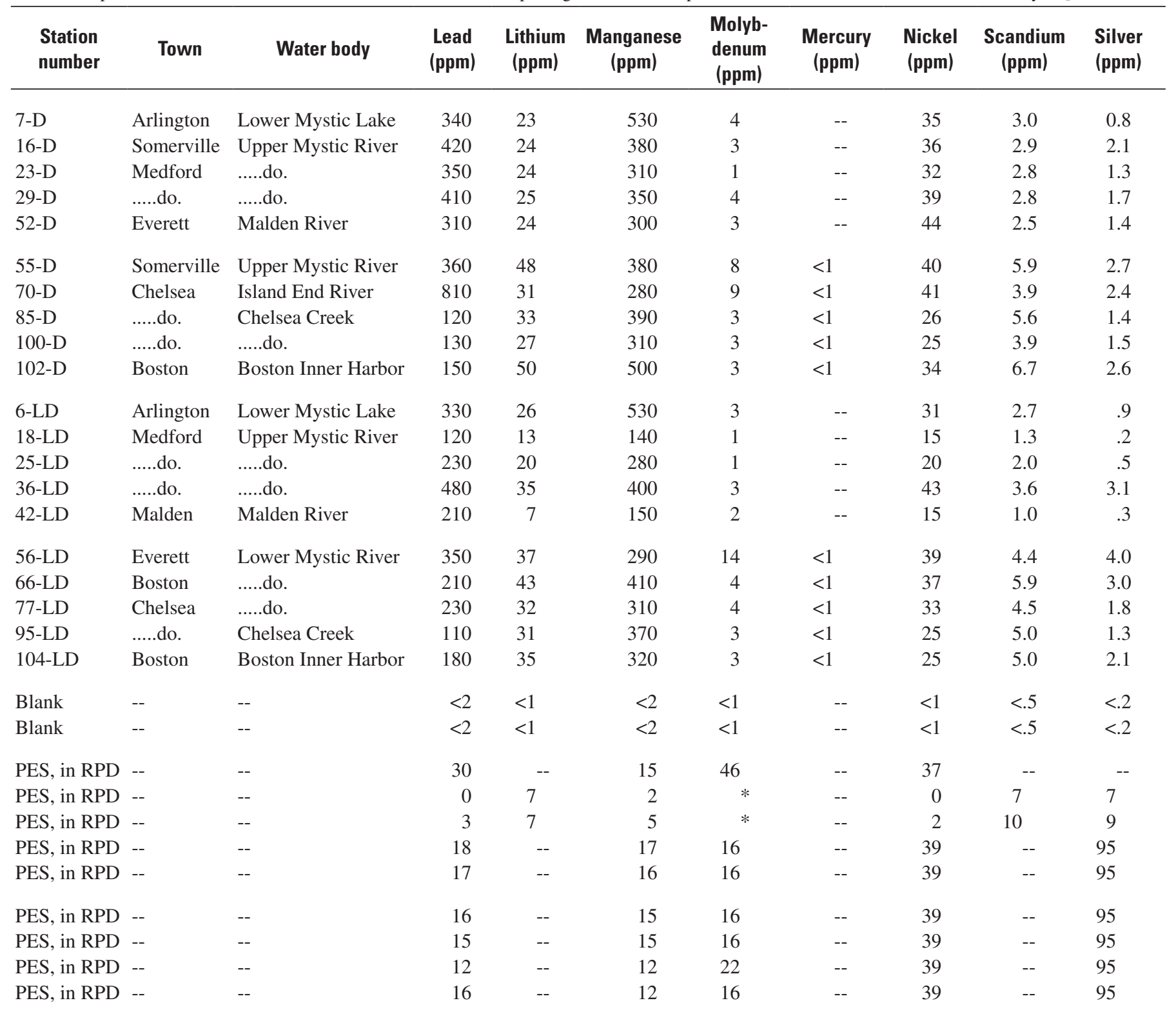


Table 3. Distribution of element and organic compound concentrations measured in sediment grab samples, Mystic River Basin, Massachusetts.-Continued

[Station number: USGS sample identifiers and geographical coordinates are given in table 1; sampling locations shown on figure 3. BHC, 1,2,3,4,5,6-hexachlorocyclohexane; D, duplicate; DDD, dichlorodiphenyldichloroethane; DDE, dichlorodiphenyldichloroethylene; DDT, dichlorodiphenyltrichloroethane; do., ditto; LD, lab duplicate; No., number; PES, Performance Evaluation Standard; RPD, relative percent difference; USGS, U.S. Geological Survey; ppm, parts per million; \%, percent; <, actual value shown is less than the minimum reporting limit; *, PES reported value was less than detection; --, not analyzed]

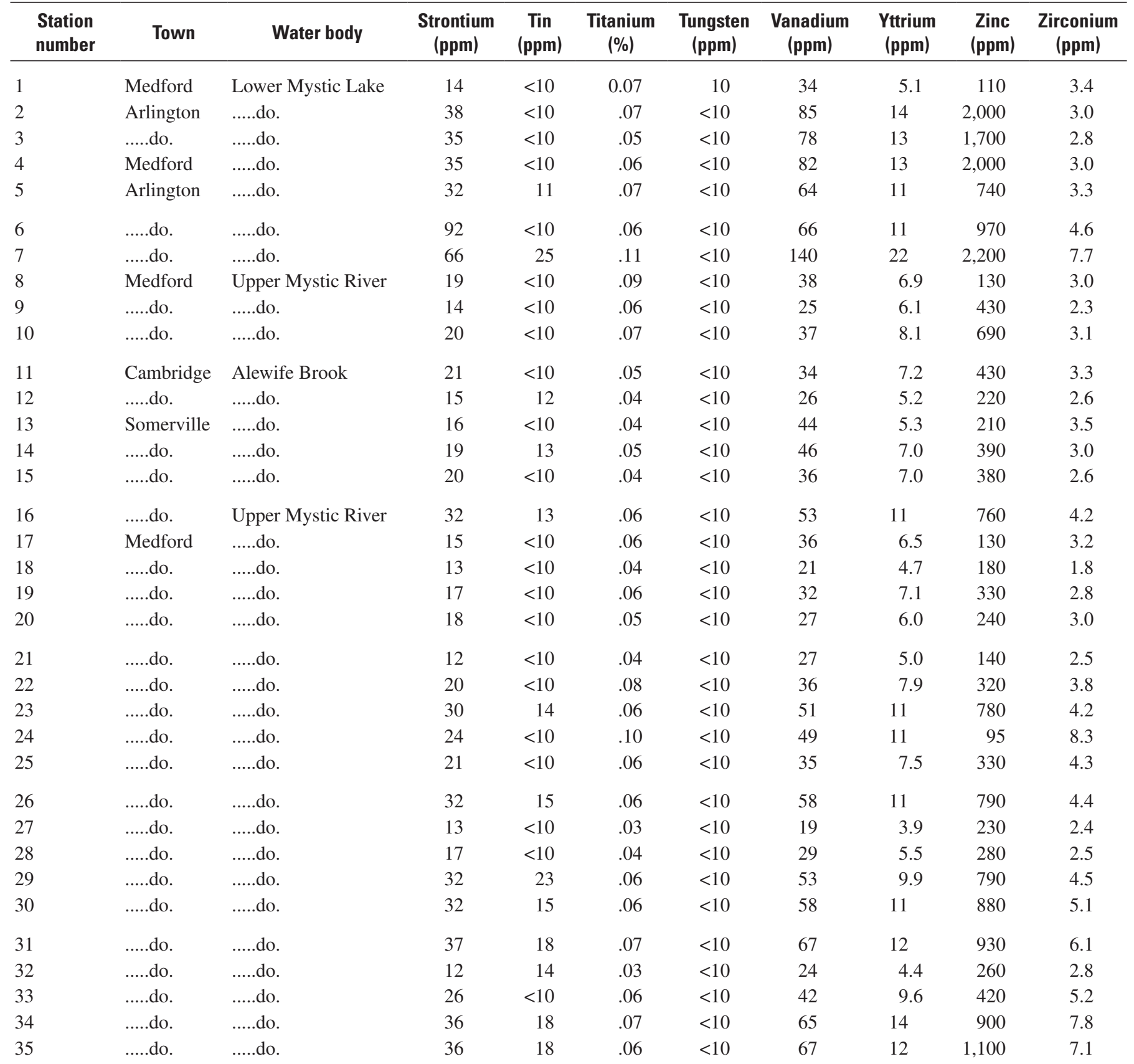


Table 3. Distribution of element and organic compound concentrations measured in sediment grab samples, Mystic River Basin, Massachusetts.—Continued

[Station number: USGS sample identifiers and geographical coordinates are given in table 1; sampling locations shown on figure 3. BHC, 1,2,3,4,5,6-hexachlorocyclohexane; D, duplicate; DDD, dichlorodiphenyldichloroethane; DDE, dichlorodiphenyldichloroethylene; DDT, dichlorodiphenyltrichloroethane; do., ditto; LD, lab duplicate; No., number; PES, Performance Evaluation Standard; RPD, relative percent difference; USGS, U.S. Geological Survey; ppm, parts per million; \%, percent; <, actual value shown is less than the minimum reporting limit; *, PES reported value was less than detection; --, not analyzed]

\begin{tabular}{|c|c|c|c|c|c|c|c|c|c|c|}
\hline $\begin{array}{l}\text { Station } \\
\text { number }\end{array}$ & Town & Water body & $\begin{array}{c}\text { Strontium } \\
\text { (ppm) }\end{array}$ & $\underset{\text { (ppm) }}{\text { Tin }}$ & $\begin{array}{c}\text { Titanium } \\
(\%)\end{array}$ & $\begin{array}{c}\text { Tungsten } \\
\text { (ppm) }\end{array}$ & $\begin{array}{c}\text { Vanadium } \\
\text { (ppm) }\end{array}$ & $\begin{array}{c}\text { Yttrium } \\
\text { (ppm) }\end{array}$ & $\begin{array}{c}\text { Zinc } \\
\text { (ppm) }\end{array}$ & $\begin{array}{l}\text { Zirconium } \\
\text { (ppm) }\end{array}$ \\
\hline 36 & Medford & Upper Mystic River & 34 & 18 & 0.07 & $<10$ & 64 & 12 & 960 & 6.9 \\
\hline 38 & Medford & .....do. & 37 & 19 & .06 & $<10$ & 67 & 13 & 1,000 & 7.1 \\
\hline 39 & .....do. & .....do. & 35 & 18 & .07 & $<10$ & 63 & 12 & 950 & 6.9 \\
\hline 40 & .....do. & .....do. & 31 & 14 & .07 & $<10$ & 68 & 10 & 570 & 6.8 \\
\hline 42 & Malden & Malden River & 12 & $<10$ & .03 & $<10$ & 24 & 4.4 & 190 & 3.0 \\
\hline 43 & .....do. & .....do. & 23 & 13 & .04 & $<10$ & 35 & 6.0 & 430 & 2.8 \\
\hline 44 & .....do. & .....do. & 40 & 15 & .03 & $<10$ & 43 & 6.9 & 630 & 3.4 \\
\hline 45 & .....do. & .....do. & 20 & $<10$ & .06 & $<10$ & 43 & 7.2 & 580 & 4.6 \\
\hline 50 & .....do. & .....do. & 28 & 18 & .05 & $<10$ & 58 & 9.3 & 700 & 6.1 \\
\hline 51 & .....do. & .....do. & 29 & 12 & .05 & $<10$ & 49 & 7.8 & 500 & 5.2 \\
\hline 52 & .....do. & .....do. & 39 & 37 & .05 & $<10$ & 75 & 9.4 & 820 & 6.3 \\
\hline 53 & .....do. & Upper Mystic River & 54 & 20 & .06 & $<10$ & 77 & 12 & 860 & 7.7 \\
\hline 54 & .....do. & .....do. & 55 & 28 & .07 & $<10$ & 91 & 12 & 820 & 8.4 \\
\hline 55 & Somerville & Lower Mystic River & 93 & 14 & .13 & $<10$ & 100 & 13 & 690 & 18 \\
\hline 56 & Everett & .....do. & 96 & 13 & .10 & $<10$ & 110 & 12 & 660 & 17 \\
\hline 57 & .....do. & .....do. & 42 & $<10$ & .07 & $<10$ & 33 & 8.3 & 89 & 7.8 \\
\hline 58 & Boston & .....do. & 150 & 14 & .13 & $<10$ & 110 & 14 & 510 & 16 \\
\hline 65 & .....do. & .....do. & 69 & $<10$ & .12 & $<10$ & 94 & 12 & 360 & 15 \\
\hline 66 & Boston & .....do. & 73 & $<10$ & .13 & $<10$ & 100 & 13 & 330 & 14 \\
\hline 67 & Everett & .....do. & 84 & $<10$ & .11 & $<10$ & 68 & 11 & 200 & 12 \\
\hline 68 & Boston & .....do. & 67 & $<10$ & .13 & $<10$ & 87 & 13 & 270 & 14 \\
\hline 69 & Everett & .....do. & 55 & $<10$ & .13 & $<10$ & 76 & 13 & 220 & 13 \\
\hline 70 & Chelsea & Island End River & 76 & 20 & .10 & $<10$ & 110 & 11 & 1300 & 15 \\
\hline
\end{tabular}


Table 3. Distribution of element and organic compound concentrations measured in sediment grab samples, Mystic River Basin, Massachusetts.-Continued

[Station number: USGS sample identifiers and geographical coordinates are given in table 1; sampling locations shown on figure 3. BHC, 1,2,3,4,5,6-hexachlorocyclohexane; D, duplicate; DDD, dichlorodiphenyldichloroethane; DDE, dichlorodiphenyldichloroethylene; DDT, dichlorodiphenyltrichloroethane; do., ditto; LD, lab duplicate; No., number; PES, Performance Evaluation Standard; RPD, relative percent difference; USGS, U.S. Geological Survey; ppm, parts per million; \%, percent; <, actual value shown is less than the minimum reporting limit; *, PES reported value was less than detection; --, not analyzed]

\begin{tabular}{|c|c|c|c|c|c|c|c|c|c|c|}
\hline $\begin{array}{l}\text { Station } \\
\text { number }\end{array}$ & Town & Water body & $\begin{array}{l}\text { Strontium } \\
\text { (ppm) }\end{array}$ & $\underset{(p p m)}{\operatorname{Tin}}$ & $\begin{array}{c}\text { Titanium } \\
(\%)\end{array}$ & $\begin{array}{c}\text { Tungsten } \\
\text { (ppm) }\end{array}$ & $\begin{array}{c}\text { Vanadium } \\
\text { (ppm) }\end{array}$ & $\begin{array}{c}\text { Yttrium } \\
\text { (ppm) }\end{array}$ & $\begin{array}{c}\text { Zinc } \\
\text { (ppm) }\end{array}$ & $\begin{array}{l}\text { Zirconium } \\
\quad(p p m)\end{array}$ \\
\hline 71 & Everett & Island End River & 66 & 12 & 0.12 & $<10$ & 95 & 13 & 530 & 16 \\
\hline 73 & .....do. & .....do. & 53 & $<10$ & .06 & $<10$ & 55 & 8.1 & 220 & 8.5 \\
\hline 74 & .....do. & .....do. & 58 & $<10$ & .10 & $<10$ & 83 & 11 & 290 & 12 \\
\hline 75 & Boston & Lower Mystic River & 63 & $<10$ & .15 & $<10$ & 88 & 15 & 260 & 15 \\
\hline 77 & Chelsea & .....do. & 59 & 13 & .11 & $<10$ & 77 & 12 & 340 & 14 \\
\hline 78 & .....do. & .....do. & 61 & $<10$ & .13 & $<10$ & 78 & 13 & 230 & 13 \\
\hline 79 & .....do. & .....do. & 47 & $<10$ & .13 & $<10$ & 63 & 13 & 180 & 12 \\
\hline 80 & .....do. & Mill Creek & 120 & 16 & .12 & $<10$ & 84 & 13 & 430 & 14 \\
\hline 81 & Revere & Chelsea Creek & 59 & $<10$ & .12 & $<10$ & 65 & 13 & 280 & 13 \\
\hline 85 & .....do. & .....do. & 48 & $<10$ & .11 & $<10$ & 61 & 12 & 180 & 12 \\
\hline 86 & Boston & .....do. & 34 & $<10$ & .08 & $<10$ & 37 & 9.0 & 140 & 8.8 \\
\hline 87 & Chelsea & .....do. & 60 & $<10$ & .11 & $<10$ & 62 & 12 & 250 & 12 \\
\hline 88 & .....do. & .....do. & 81 & $<10$ & .11 & $<10$ & 65 & 12 & 200 & 12 \\
\hline 89 & Boston & .....do. & 53 & 19 & .09 & $<10$ & 47 & 9.1 & 180 & 9.1 \\
\hline 90 & .....do. & .....do. & 47 & $<10$ & .09 & $<10$ & 49 & 9.9 & 190 & 9.5 \\
\hline 91 & .....do. & .....do. & 49 & $<10$ & .10 & $<10$ & 58 & 11 & 170 & 11 \\
\hline 92 & Chelsea & .....do. & 45 & $<10$ & .10 & $<10$ & 58 & 12 & 180 & 10 \\
\hline 93 & .....do. & .....do. & 52 & $<10$ & .12 & $<10$ & 73 & 13 & 250 & 13 \\
\hline 101 & Boston & .....do. & 49 & $<10$ & .10 & $<10$ & 55 & 10 & 170 & 9.9 \\
\hline 102 & .....do. & Boston Inner Harbor & 58 & $<10$ & .13 & $<10$ & 75 & 13 & 210 & 13 \\
\hline 103 & .....do. & .....do. & 61 & 12 & .13 & $<10$ & 85 & 14 & 310 & 15 \\
\hline 104 & .....do. & .....do. & 44 & $<10$ & .11 & $<10$ & 60 & 11 & 240 & 11 \\
\hline
\end{tabular}


Table 3. Distribution of element and organic compound concentrations measured in sediment grab samples, Mystic River Basin, Massachusetts.—Continued

[Station number: USGS sample identifiers and geographical coordinates are given in table 1; sampling locations shown on figure 3. BHC, 1,2,3,4,5,6-hexachlorocyclohexane; D, duplicate; DDD, dichlorodiphenyldichloroethane; DDE, dichlorodiphenyldichloroethylene; DDT, dichlorodiphenyltrichloroethane; do., ditto; LD, lab duplicate; No., number; PES, Performance Evaluation Standard; RPD, relative percent difference; USGS, U.S. Geological Survey; ppm, parts per million; \%, percent; <, actual value shown is less than the minimum reporting limit; *, PES reported value was less than detection; --, not analyzed]

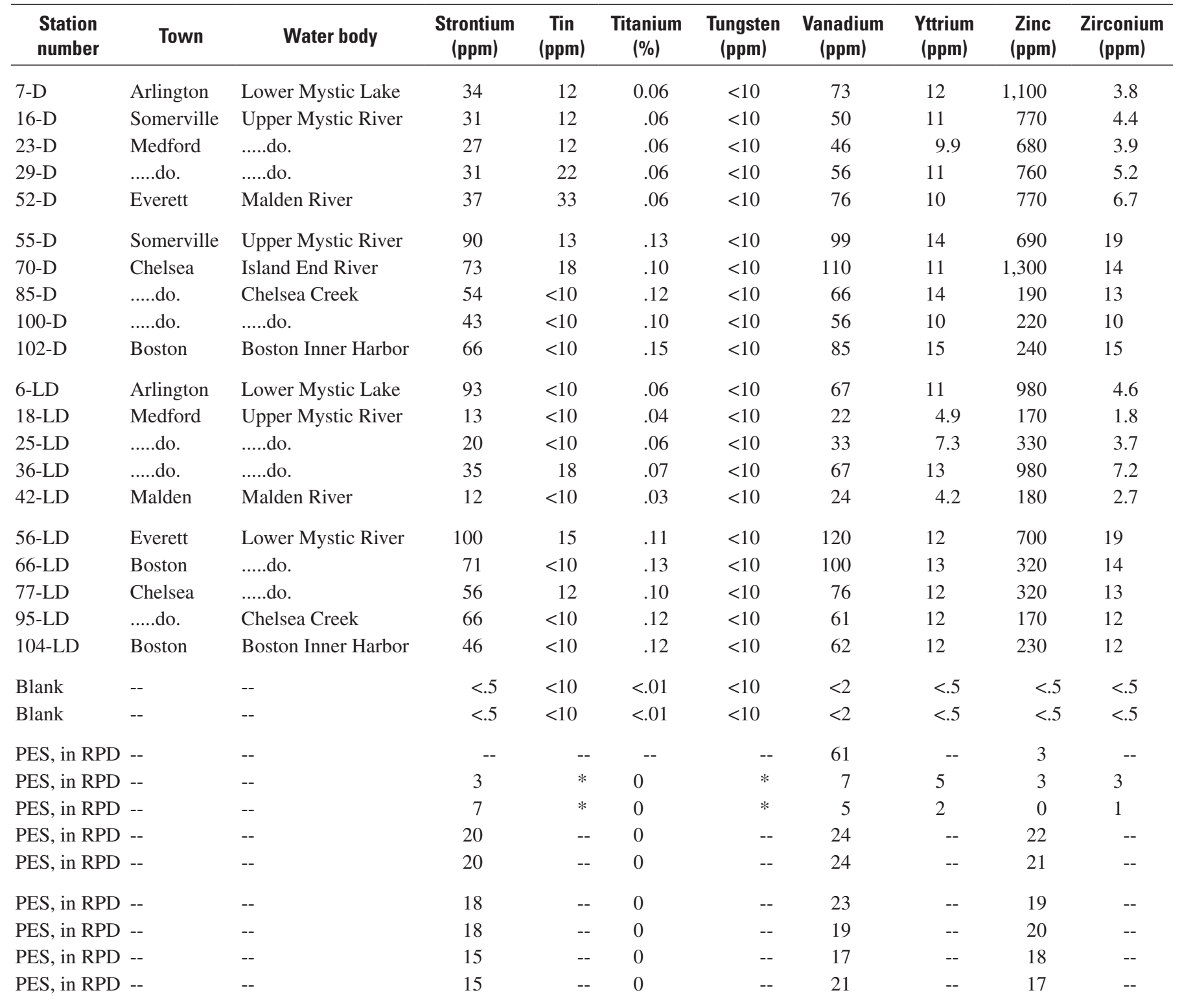


Table 3. Distribution of element and organic compound concentrations measured in sediment grab samples, Mystic River Basin, Massachusetts.-Continued

[Station number: USGS sample identifiers and geographical coordinates are given in table 1; sampling locations shown on figure 3. BHC, 1,2,3,4,5,6-hexachlorocyclohexane; D, duplicate; DDD, dichlorodiphenyldichloroethane; DDE, dichlorodiphenyldichloroethylene; DDT, dichlorodiphenyltrichloro-ethane; do., ditto; LD, lab duplicate; No., number; PES, Performance Evaluation Standard; RPD, relative percent difference; USGS, U.S. Geological Survey; ppm, parts per million; \%, percent; <, actual value shown is less than the minimum reporting limit; *, PES reported value was less than detection; --, not analyzed]

\begin{tabular}{|c|c|c|c|c|c|c|c|c|c|}
\hline $\begin{array}{c}\text { Station } \\
\text { No. }\end{array}$ & Town & Water body & $\begin{array}{l}\text { PCBs, } \\
\text { CI1CI10 } \\
\text { (ppm) }\end{array}$ & $\begin{array}{l}\text { Aldrin } \\
\text { (ppm) }\end{array}$ & $\begin{array}{l}\text { alpha- } \\
\text { BHC } \\
\text { (ppm) }\end{array}$ & $\begin{array}{l}\text { beta- } \\
\text { BHC } \\
\text { (ppm) }\end{array}$ & $\begin{array}{l}\text { delta- } \\
\text { BHC } \\
\text { (ppm) }\end{array}$ & $\begin{array}{c}\text { gamma- } \\
\text { BHC } \\
\text { (ppm) }\end{array}$ & $\begin{array}{l}\text { DDE } \\
\text { (ppm) }\end{array}$ \\
\hline 2 & Arlington & .....do. & $<0.15-0.87$ & $<.061$ & $<.059$ & $<.072$ & $<.043$ & $<.069$ & $<.012$ \\
\hline 3 & .....do. & .....do. & $<0.15-0.87$ & $<.061$ & $<.059$ & $<.072$ & $<.043$ & $<.069$ & $<.012$ \\
\hline 4 & Medford & .....do. & $<0.15-0.87$ & $<.061$ & $<.059$ & $<.072$ & $<.043$ & $<.069$ & $<.012$ \\
\hline 6 & .....do. & .....do. & $<0.15-0.87$ & $<.061$ & $<.059$ & $<.072$ & $<.043$ & $<.069$ & $<.012$ \\
\hline 7 & .....do. & .....do. & $<0.15-0.87$ & $<.061$ & $<.059$ & $<.072$ & $<.043$ & $<.069$ & $<.012$ \\
\hline 8 & Medford & Upper Mystic River & $<0.15-0.87$ & $<.061$ & $<.059$ & $<.072$ & $<.043$ & $<.069$ & $<.012$ \\
\hline 9 & .....do. & .....do. & $<0.15-0.87$ & $<.061$ & $<.059$ & $<.072$ & $<.043$ & $<.069$ & $<.012$ \\
\hline 10 & .....do. & .....do. & $<0.15-0.87$ & $<.061$ & $<.059$ & $<.072$ & $<.043$ & $<.069$ & $<.012$ \\
\hline 15 & .....do. & .....do. & $<0.15-0.87$ & $<.061$ & $<.059$ & $<.072$ & $<.043$ & $<.069$ & $<.012$ \\
\hline 16 & .....do. & Upper Mystic River & $<0.15-0.87$ & $<.061$ & $<.059$ & $<.072$ & $<.043$ & $<.069$ & $<.012$ \\
\hline 17 & Medford & .....do. & $<0.15-0.87$ & $<.061$ & $<.059$ & $<.072$ & $<.043$ & $<.069$ & $<.012$ \\
\hline 18 & .....do. & .....do. & $<0.15-0.87$ & $<.061$ & $<.059$ & $<.072$ & $<.043$ & $<.069$ & $<.012$ \\
\hline 19 & .....do. & .....do. & $<0.15-0.87$ & $<.061$ & $<.059$ & $<.072$ & $<.043$ & $<.069$ & $<.012$ \\
\hline 20 & .....do. & .....do. & $<0.15-0.87$ & $<.061$ & $<.059$ & $<.072$ & $<.043$ & $<.069$ & $<.012$ \\
\hline 21 & .....do. & .....do. & $<0.15-0.87$ & $<.061$ & $<.059$ & $<.072$ & $<.043$ & $<.069$ & $<.012$ \\
\hline 22 & .....do. & .....do. & $<0.15-0.87$ & $<.061$ & $<.059$ & $<.072$ & $<.043$ & $<.069$ & $<.012$ \\
\hline 23 & .....do. & .....do. & $<0.15-0.87$ & $<.061$ & $<.059$ & $<.072$ & $<.043$ & $<.069$ & $<.012$ \\
\hline 24 & .....do. & .....do. & $<0.15-0.87$ & $<.061$ & $<.059$ & $<.072$ & $<.043$ & $<.069$ & $<.012$ \\
\hline 31 & .....do. & .....do. & $<0.15-0.87$ & $<.061$ & $<.059$ & $<.072$ & $<.043$ & $<.069$ & $<.012$ \\
\hline 32 & .....do. & .....do. & $<0.15-0.87$ & $<.061$ & $<.059$ & $<.072$ & $<.043$ & $<.069$ & $<.012$ \\
\hline 33 & .....do. & .....do. & $<0.15-0.87$ & $<.061$ & $<.059$ & $<.072$ & $<.043$ & $<.069$ & $<.012$ \\
\hline 34 & .....do. & .....do. & $<0.15-0.87$ & $<.061$ & $<.059$ & $<.072$ & $<.043$ & $<.069$ & $<.012$ \\
\hline 35 & .....do. & .....do. & $<0.15-0.87$ & $<.061$ & $<.059$ & $<.072$ & $<.043$ & $<.069$ & $<.012$ \\
\hline 36 & .....do. & .....do. & $<0.15-0.87$ & $<.061$ & $<.059$ & $<.072$ & $<.043$ & $<.069$ & $<.012$ \\
\hline 37 & Somerville & .....do. & $<0.15-0.87$ & $<.061$ & $<.059$ & $<.072$ & $<.043$ & $<.069$ & $<.012$ \\
\hline 38 & Medford & .....do. & $<0.15-0.87$ & $<.061$ & $<.059$ & $<.072$ & $<.043$ & $<.069$ & $<.012$ \\
\hline 39 & .....do. & .....do. & $<0.15-0.87$ & $<.061$ & $<.059$ & $<.072$ & $<.043$ & $<.069$ & $<.012$ \\
\hline 40 & .....do. & .....do. & $<0.15-0.87$ & $<.061$ & $<.059$ & $<.072$ & $<.043$ & $<.069$ & $<.012$ \\
\hline 41 & Everett & Upper Mystic River & $<0.15-0.87$ & $<.061$ & $<.059$ & $<.072$ & $<.043$ & $<.069$ & $<.012$ \\
\hline 42 & Malden & Malden River & $<0.15-0.87$ & $<.061$ & $<.059$ & $<.072$ & $<.043$ & $<.069$ & $<.012$ \\
\hline
\end{tabular}


Table 3. Distribution of element and organic compound concentrations measured in sediment grab samples, Mystic River Basin, Massachusetts.-Continued

[Station number: USGS sample identifiers and geographical coordinates are given in table 1; sampling locations shown on figure 3. BHC, 1,2,3,4,5,6-hexachlorocyclohexane; D, duplicate; DDD, dichlorodiphenyldichloroethane; DDE, dichlorodiphenyldichloroethylene; DDT, dichlorodiphenyltrichloro-ethane; do., ditto; LD, lab duplicate; No., number; PES, Performance Evaluation Standard; RPD, relative percent difference; USGS, U.S. Geological Survey; ppm, parts per million; \%, percent; <, actual value shown is less than the minimum reporting limit; *, PES reported value was less than detection; --, not analyzed]

\begin{tabular}{|c|c|c|c|c|c|c|c|c|c|}
\hline $\begin{array}{c}\text { Station } \\
\text { No. }\end{array}$ & Town & Water body & $\begin{array}{c}\text { PCBs, } \\
\text { Cl1CI10 } \\
\text { (ppm) }\end{array}$ & $\begin{array}{l}\text { Aldrin } \\
\text { (ppm) }\end{array}$ & $\begin{array}{l}\text { alpha- } \\
\text { BHC } \\
\text { (ppm) }\end{array}$ & $\begin{array}{l}\text { beta- } \\
\text { BHC } \\
\text { (ppm) }\end{array}$ & $\begin{array}{l}\text { delta- } \\
\text { BHC } \\
\text { (ppm) }\end{array}$ & $\begin{array}{c}\text { gamma- } \\
\text { BHC } \\
\text { (ppm) }\end{array}$ & $\begin{array}{c}\text { DDE } \\
\text { (ppm) }\end{array}$ \\
\hline 44 & .....do. & .....do. & $<0.15-0.87$ & $<.061$ & $<.059$ & $<.072$ & $<.043$ & $<.069$ & $<.012$ \\
\hline 45 & .....do. & .....do. & $<0.15-0.87$ & $<.061$ & $<.059$ & $<.072$ & $<.043$ & $<.069$ & $<.012$ \\
\hline 46 & Everett & Malden River & $<0.15-0.87$ & $<.061$ & $<.059$ & $<.072$ & $<.043$ & $<.069$ & $<.012$ \\
\hline 48 & .....do. & .....do. & $<0.15-0.87$ & $<.061$ & $<.059$ & $<.072$ & $<.043$ & $<.069$ & $<.012$ \\
\hline 49 & .....do. & .....do. & $<0.15-0.87$ & $<.061$ & $<.059$ & $<.072$ & $<.043$ & $<.069$ & $<.012$ \\
\hline 50 & .....do. & .....do. & $<0.15-0.87$ & $<.061$ & $<.059$ & $<.072$ & $<.043$ & $<.069$ & $<.012$ \\
\hline 51 & .....do. & .....do. & $<0.15-0.87$ & $<.061$ & $<.059$ & $<.072$ & $<.043$ & $<.069$ & $<.012$ \\
\hline 52 & .....do. & .....do. & $<0.15-0.87$ & $<.061$ & $<.059$ & $<.072$ & $<.043$ & $<.069$ & $<.012$ \\
\hline 57 & .....do. & .....do. & $<0.15-0.87$ & $<.061$ & $<.059$ & $<.072$ & $<.043$ & $<.069$ & $<.012$ \\
\hline 58 & Boston & .....do. & $<0.15-0.87$ & $<.061$ & $<.059$ & $<.072$ & $<.043$ & $<.069$ & $<.012$ \\
\hline 59 & .....do. & .....do. & $<0.15-0.87$ & $<.061$ & $<.059$ & $<.072$ & $<.043$ & $<.069$ & $<.012$ \\
\hline 60 & .....do. & .....do. & $<0.15-0.87$ & $<.061$ & $<.059$ & $<.072$ & $<.043$ & $<.069$ & $<.012$ \\
\hline 61 & .....do. & .....do. & $<0.15-0.87$ & $<.061$ & $<.059$ & $<.072$ & $<.043$ & $<.069$ & $<.012$ \\
\hline 62 & Everett & .....do. & $<0.15-0.87$ & $<.061$ & $<.059$ & $<.072$ & $<.043$ & $<.069$ & $<.012$ \\
\hline 63 & Boston & .....do. & $<0.15-0.87$ & $<.061$ & $<.059$ & $<.072$ & $<.043$ & $<.069$ & $<.012$ \\
\hline 64 & Everett & .....do. & $<0.15-0.87$ & $<.061$ & $<.059$ & $<.072$ & $<.043$ & $<.069$ & $<.012$ \\
\hline 65 & .....do. & .....do. & $<0.15-0.87$ & $<.061$ & $<.059$ & $<.072$ & $<.043$ & $<.069$ & $<.012$ \\
\hline 66 & Boston & .....do. & $<0.15-0.87$ & $<.061$ & $<.059$ & $<.072$ & $<.043$ & $<.069$ & $<.012$ \\
\hline 73 & .....do. & .....do. & $<0.15-0.87$ & $<.061$ & $<.059$ & $<.072$ & $<.043$ & $<.069$ & $<.012$ \\
\hline 74 & .....do. & .....do. & $<0.15-0.87$ & $<.061$ & $<.059$ & $<.072$ & $<.043$ & $<.069$ & $<.012$ \\
\hline 75 & Boston & Lower Mystic River & $<0.15-0.87$ & $<.061$ & $<.059$ & $<.072$ & $<.043$ & $<.069$ & $<.012$ \\
\hline 76 & .....do. & .....do. & $<0.15-0.87$ & $<.061$ & $<.059$ & $<.072$ & $<.043$ & $<.069$ & $<.012$ \\
\hline 77 & Chelsea & .....do. & $<0.15-0.87$ & $<.061$ & $<.059$ & $<.072$ & $<.043$ & $<.069$ & $<.012$ \\
\hline 78 & .....do. & .....do. & $<0.15-0.87$ & $<.061$ & $<.059$ & $<.072$ & $<.043$ & $<.069$ & $<.012$ \\
\hline 79 & .....do. & .....do. & $<0.15-0.87$ & $<.061$ & $<.059$ & $<.072$ & $<.043$ & $<.069$ & $<.012$ \\
\hline 80 & .....do. & Mill Creek & $<0.15-0.87$ & $<.061$ & $<.059$ & $<.072$ & $<.043$ & $<.069$ & $<.012$ \\
\hline 81 & Revere & Chelsea Creek & $<0.15-0.87$ & $<.061$ & $<.059$ & $<.072$ & $<.043$ & $<.069$ & $<.012$ \\
\hline 82 & .....do. & .....do. & $<0.15-0.87$ & $<.061$ & $<.059$ & $<.072$ & $<.043$ & $<.069$ & $<.012$ \\
\hline 83 & Chelsea & .....do. & $<0.15-0.87$ & $<.061$ & $<.059$ & $<.072$ & $<.043$ & $<.069$ & $<.012$ \\
\hline 84 & .....do. & .....do. & $<0.15-0.87$ & $<.061$ & $<.059$ & $<.072$ & $<.043$ & $<.069$ & $<.012$ \\
\hline 85 & .....do. & .....do. & $<0.15-0.87$ & $<.061$ & $<.059$ & $<.072$ & $<.043$ & $<.069$ & $<.012$ \\
\hline
\end{tabular}


Table 3. Distribution of element and organic compound concentrations measured in sediment grab samples, Mystic River Basin, Massachusetts.-Continued

[Station number: USGS sample identifiers and geographical coordinates are given in table 1; sampling locations shown on figure 3. BHC, 1,2,3,4,5,6-hexachlorocyclohexane; D, duplicate; DDD, dichlorodiphenyldichloroethane; DDE, dichlorodiphenyldichloroethylene; DDT, dichlorodiphenyltrichloro-ethane; do., ditto; LD, lab duplicate; No., number; PES, Performance Evaluation Standard; RPD, relative percent difference; USGS, U.S. Geological Survey; ppm, parts per million; \%, percent; <, actual value shown is less than the minimum reporting limit; *, PES reported value was less than detection; --, not analyzed]

\begin{tabular}{|c|c|c|c|c|c|c|c|c|c|}
\hline $\begin{array}{c}\text { Station } \\
\text { No. }\end{array}$ & Town & Water body & $\begin{array}{l}\text { PCBs, } \\
\text { CI1CI10 } \\
\text { (ppm) }\end{array}$ & $\begin{array}{l}\text { Aldrin } \\
\text { (ppm) }\end{array}$ & $\begin{array}{l}\text { alpha- } \\
\text { BHC } \\
\text { (ppm) }\end{array}$ & $\begin{array}{l}\text { beta- } \\
\text { BHC } \\
\text { (ppm) }\end{array}$ & $\begin{array}{l}\text { delta- } \\
\text { BHC } \\
\text { (ppm) }\end{array}$ & $\begin{array}{c}\text { gamma- } \\
\text { BHC } \\
\text { (ppm) }\end{array}$ & $\begin{array}{l}\text { DDE } \\
\text { (ppm) }\end{array}$ \\
\hline 87 & Chelsea & .....do. & $<0.15-0.87$ & $<.061$ & $<.059$ & $<.072$ & $<.043$ & $<.069$ & $<.012$ \\
\hline 88 & .....do. & .....do. & $<0.15-0.87$ & $<.061$ & $<.059$ & $<.072$ & $<.043$ & $<.069$ & $<.012$ \\
\hline 89 & Boston & .....do. & $<0.15-0.87$ & $<.061$ & $<.059$ & $<.072$ & $<.043$ & $<.069$ & $<.012$ \\
\hline 91 & Boston & Chelsea Creek & $<0.15-0.87$ & $<.061$ & $<.059$ & $<.072$ & $<.043$ & $<.069$ & $<.012$ \\
\hline 92 & Chelsea & .....do. & $<0.15-0.87$ & $<.061$ & $<.059$ & $<.072$ & $<.043$ & $<.069$ & $<.012$ \\
\hline 93 & .....do. & .....do. & $<0.15-0.87$ & $<.061$ & $<.059$ & $<.072$ & $<.043$ & $<.069$ & $<.012$ \\
\hline 94 & Boston & .....do. & $<0.15-0.87$ & $<.061$ & $<.059$ & $<.072$ & $<.043$ & $<.069$ & $<.012$ \\
\hline 95 & Chelsea & .....do. & $<0.15-0.87$ & $<.061$ & $<.059$ & $<.072$ & $<.043$ & $<.069$ & $<.012$ \\
\hline 100 & .....do. & .....do. & $<0.15-0.87$ & $<.061$ & $<.059$ & $<.072$ & $<.043$ & $<.069$ & $<.012$ \\
\hline 101 & Boston & .....do. & $<0.15-0.87$ & $<.061$ & $<.059$ & $<.072$ & $<.043$ & $<.069$ & $<.012$ \\
\hline 102 & .....do. & Boston Inner Harbor & $<0.15-0.87$ & $<.061$ & $<.059$ & $<.072$ & $<.043$ & $<.069$ & $<.012$ \\
\hline 103 & .....do. & .....do. & $<0.15-0.87$ & $<.061$ & $<.059$ & $<.072$ & $<.043$ & $<.069$ & $<.012$ \\
\hline 104 & .....do. & .....do. & $<0.15-0.87$ & $<.061$ & $<.059$ & $<.072$ & $<.043$ & $<.069$ & $<.012$ \\
\hline 7-D & Arlington & Lower Mystic Lake & $<0.15-0.87$ & $<.061$ & $<.059$ & $<.072$ & $<.043$ & $<.069$ & $<.012$ \\
\hline $16-\mathrm{D}$ & Somerville & Upper Mystic River & $<0.15-0.87$ & $<.061$ & $<.059$ & $<.072$ & $<.043$ & $<.069$ & $<.012$ \\
\hline 23-D & Medford & .....do. & $<0.15-0.87$ & $<.061$ & $<.059$ & $<.072$ & $<.043$ & $<.069$ & $<.012$ \\
\hline 29-D & .....do. & .....do. & $<0.15-0.87$ & $<.061$ & $<.059$ & $<.072$ & $<.043$ & $<.069$ & $<.012$ \\
\hline $55-\mathrm{D}$ & Somerville & Lower Mystic River & $<0.15-0.87$ & $<.061$ & $<.059$ & $<.072$ & $<.043$ & $<.069$ & $<.012$ \\
\hline 19-LD & .....do. & .....do. & $<0.15-0.87$ & $<.061$ & $<.059$ & $<.072$ & $<.043$ & $<.069$ & $<.012$ \\
\hline 19-LD & .....do. & .....do. & $<0.15-0.87$ & $<.061$ & $<.059$ & $<.072$ & $<.043$ & $<.069$ & $<.012$ \\
\hline 27-LD & .....do. & .....do. & $<0.15-0.87$ & $<.061$ & $<.059$ & $<.072$ & $<.043$ & $<.069$ & $<.012$ \\
\hline 27-LD & .....do. & .....do. & $<0.15-0.87$ & $<.061$ & $<.059$ & $<.072$ & $<.043$ & $<.069$ & $<.012$ \\
\hline 28-LD & .....do. & .....do. & $<0.15-0.87$ & $<.061$ & $<.059$ & $<.072$ & $<.043$ & $<.069$ & $<.012$ \\
\hline 34-LD & .....do. & .....do. & $<0.15-0.87$ & $<.061$ & $<.059$ & $<.072$ & $<.043$ & $<.069$ & $<.012$ \\
\hline 54-LD & Everett & .....do. & $<0.15-0.87$ & $<.061$ & $<.059$ & $<.072$ & $<.043$ & $<.069$ & $<.012$ \\
\hline 54-LD & .....do. & .....do. & $<0.15-0.87$ & $<.061$ & $<.059$ & $<.072$ & $<.043$ & $<.069$ & $<.012$ \\
\hline 85-LD & Chelsea & Chelsea Creek & $<0.15-0.87$ & $<.061$ & $<.059$ & $<.072$ & $<.043$ & $<.069$ & $<.012$ \\
\hline
\end{tabular}


Table 3. Distribution of element and organic compound concentrations measured in sediment grab samples, Mystic River Basin, Massachusetts.-Continued

[Station number: USGS sample identifiers and geographical coordinates are given in table 1; sampling locations shown on figure 3. BHC, 1,2,3,4,5,6-hexachlorocyclohexane; D, duplicate; DDD, dichlorodiphenyldichloroethane; DDE, dichlorodiphenyldichloroethylene; DDT, dichlorodiphenyltrichloro-ethane; do., ditto; LD, lab duplicate; No., number; PES, Performance Evaluation Standard; RPD, relative percent difference; USGS, U.S. Geological Survey; ppm, parts per million; \%, percent; <, actual value shown is less than the minimum reporting limit; *, PES reported value was less than detection; --, not analyzed]

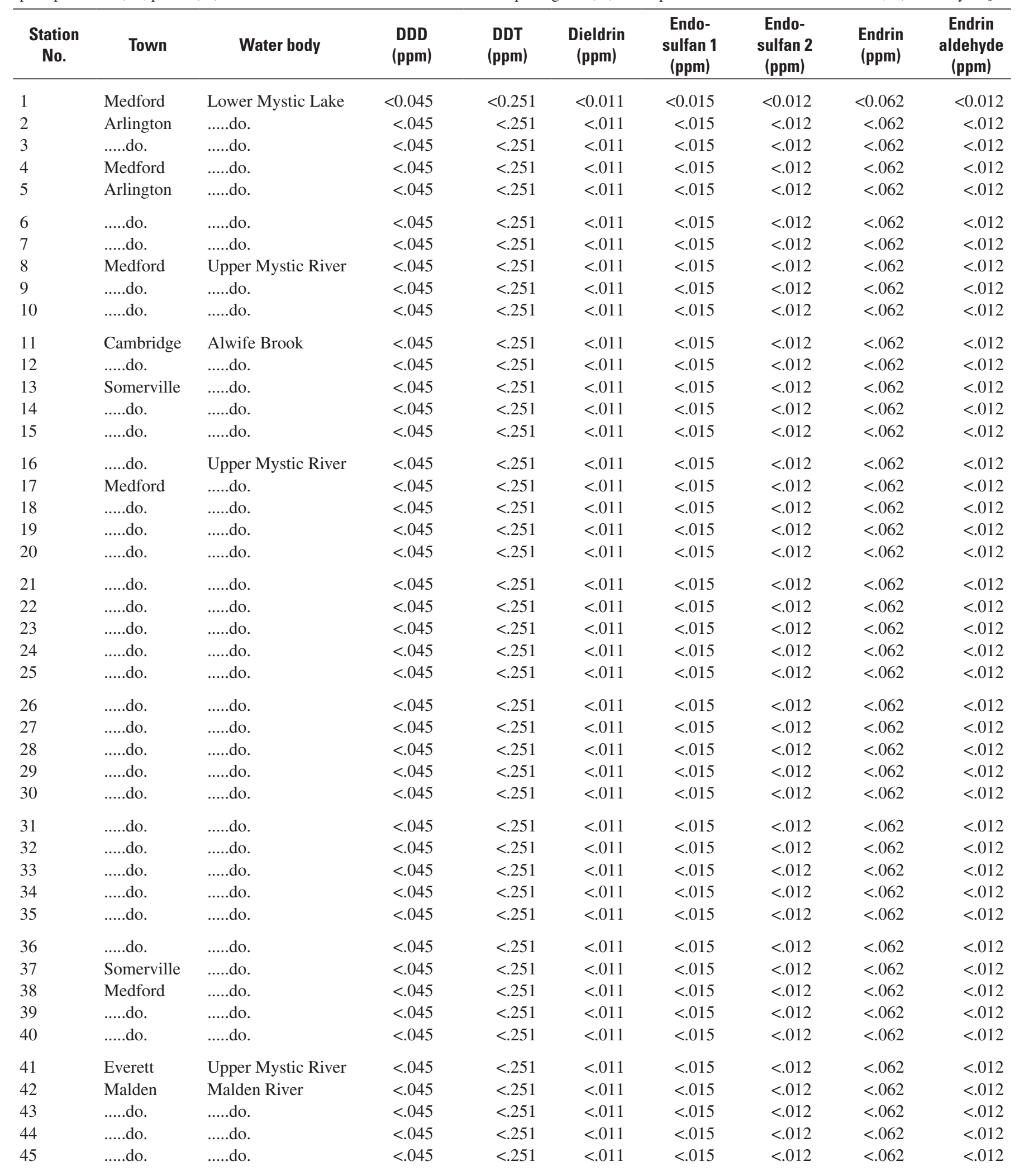


Table 3. Distribution of element and organic compound concentrations measured in sediment grab samples, Mystic River Basin, Massachusetts.-Continued

[Station number: USGS sample identifiers and geographical coordinates are given in table 1; sampling locations shown on figure 3. BHC, 1,2,3,4,5,6-hexachlorocyclohexane; D, duplicate; DDD, dichlorodiphenyldichloroethane; DDE, dichlorodiphenyldichloroethylene; DDT, dichlorodiphenyltrichloro-ethane; do., ditto; LD, lab duplicate; No., number; PES, Performance Evaluation Standard; RPD, relative percent difference; USGS, U.S. Geological Survey; ppm, parts per million; \%, percent; <, actual value shown is less than the minimum reporting limit; *, PES reported value was less than detection; --, not analyzed]

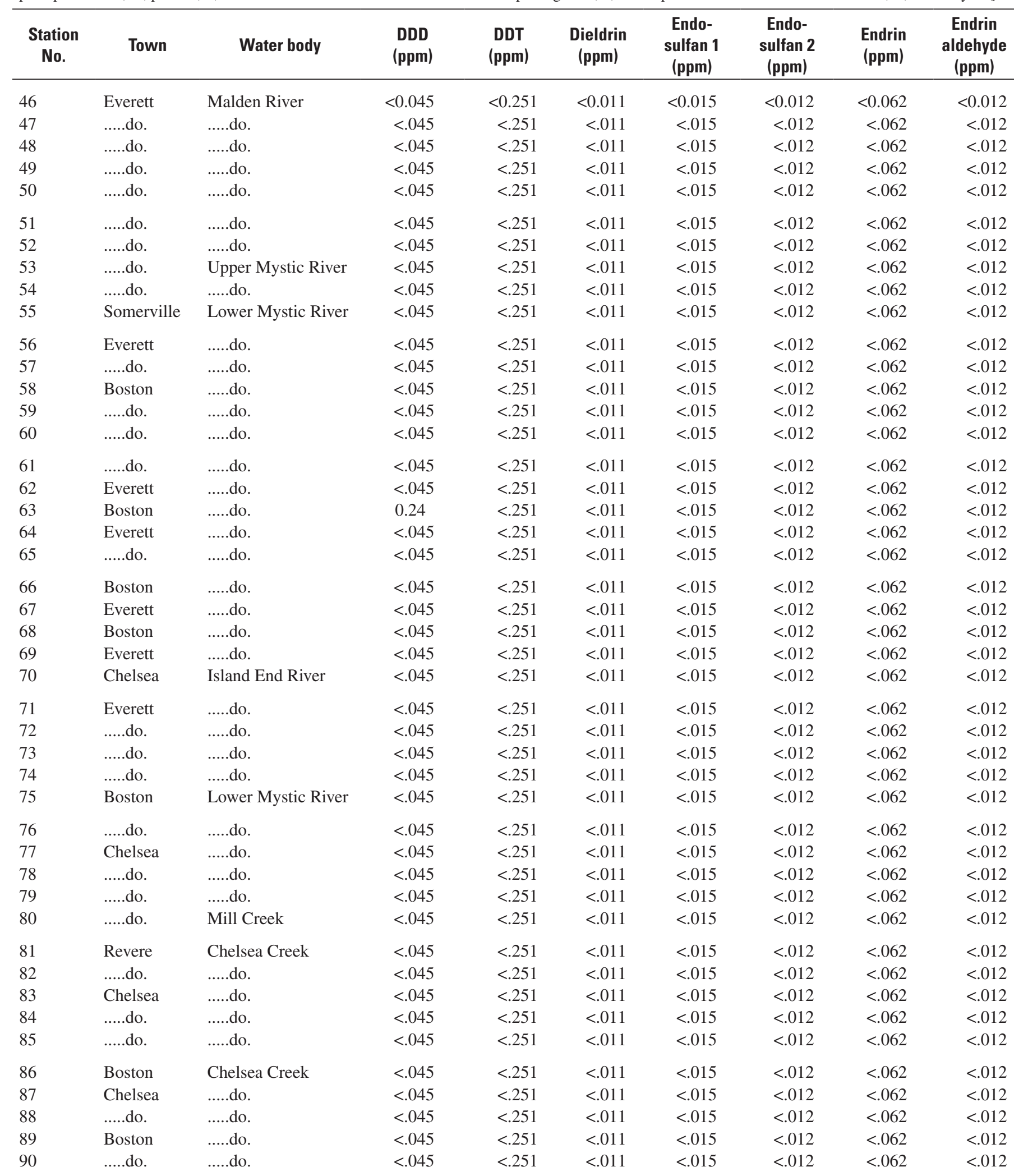


Table 3. Distribution of element and organic compound concentrations measured in sediment grab samples, Mystic River Basin, Massachusetts.-Continued

[Station number: USGS sample identifiers and geographical coordinates are given in table 1; sampling locations shown on figure 3. BHC, 1,2,3,4,5,6-hexachlorocyclohexane; D, duplicate; DDD, dichlorodiphenyldichloroethane; DDE, dichlorodiphenyldichloroethylene; DDT, dichlorodiphenyltrichloro-ethane; do., ditto; LD, lab duplicate; No., number; PES, Performance Evaluation Standard; RPD, relative percent difference; USGS, U.S. Geological Survey; ppm, parts per million; \%, percent; <, actual value shown is less than the minimum reporting limit; *, PES reported value was less than detection; --, not analyzed]

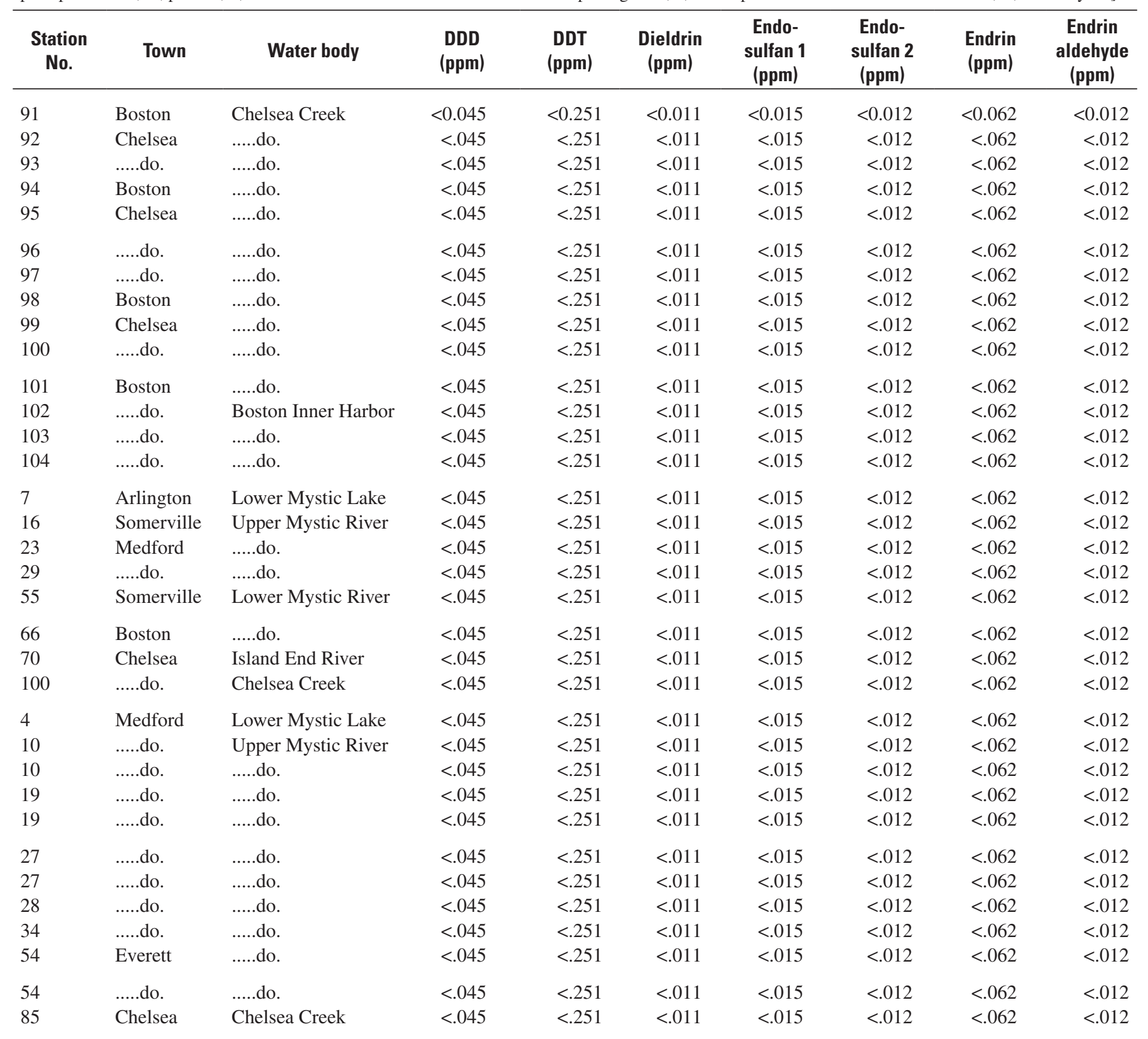


Table 3. Distribution of element and organic compound concentrations measured in sediment grab samples, Mystic River Basin, Massachusetts.-Continued

[Station number: USGS sample identifiers and geographical coordinates are given in table 1; sampling locations shown on figure 3. BHC, 1,2,3,4,5,6-hexachlorocyclohexane; D, duplicate; DDD, dichlorodiphenyldichloroethane; DDE, dichlorodiphenyldichloroethylene; DDT, dichlorodiphenyltrichloro-ethane; do., ditto; LD, lab duplicate; No., number; PES, Performance Evaluation Standard; RPD, relative percent difference; USGS, U.S. Geological Survey; ppm, parts per million; \%, percent; <, actual value shown is less than the minimum reporting limit; *, PES reported value was less than detection; --, not analyzed]

\begin{tabular}{|c|c|c|c|c|c|c|c|c|c|}
\hline $\begin{array}{c}\text { Station } \\
\text { No. }\end{array}$ & Town & Water body & $\begin{array}{l}\text { Endrin } \\
\text { ketone } \\
\text { (ppm) }\end{array}$ & $\begin{array}{c}\text { Hepta- } \\
\text { chlor } \\
\text { (ppm) }\end{array}$ & $\begin{array}{c}\text { Heptachlor } \\
\text { epoxide } \\
\text { (ppm) }\end{array}$ & $\begin{array}{c}\text { Methoxy- } \\
\text { chlor } \\
\text { (ppm) }\end{array}$ & $\begin{array}{c}\text { Acenaph- } \\
\text { thene } \\
\text { (ppm) }\end{array}$ & $\begin{array}{c}\text { Acenaph- } \\
\text { thylene } \\
\text { (ppm) }\end{array}$ & $\begin{array}{c}\text { Anthracene } \\
\text { (ppm) }\end{array}$ \\
\hline 2 & Arlington & .....do. & $<.015$ & $<.021$ & $<.072$ & $<.013$ & $<.37$ & $<.22$ & $<.29$ \\
\hline 3 & .....do. & .....do. & $<.015$ & $<.021$ & $<.072$ & $<.013$ & $<.37$ & $<.22$ & $<.29$ \\
\hline 4 & Medford & .....do. & $<.015$ & $<.021$ & $<.072$ & $<.013$ & $<.37$ & $<.22$ & $<.29$ \\
\hline 6 & .....do. & .....do. & $<.015$ & $<.021$ & $<.072$ & $<.013$ & $<.37$ & $<.22$ & $<.29$ \\
\hline 7 & .....do. & .....do. & $<.015$ & $<.021$ & $<.072$ & $<.013$ & $<.37$ & $<.22$ & $<.29$ \\
\hline 8 & Medford & Upper Mystic River & $<.015$ & $<.021$ & $<.072$ & $<.013$ & $<.37$ & $<.22$ & $<.29$ \\
\hline 9 & .....do. & .....do. & $<.015$ & $<.021$ & $<.072$ & $<.013$ & $<.37$ & $<.22$ & $<.29$ \\
\hline 10 & .....do. & .....do. & $<.015$ & $<.021$ & $<.072$ & $<.013$ & $<.37$ & $<.22$ & $<.29$ \\
\hline 15 & .....do. & ......do. & $<.015$ & $<.021$ & $<.072$ & $<.013$ & $<.37$ & $<.22$ & $<.29$ \\
\hline 16 & .....do. & Upper Mystic River & $<.015$ & $<.021$ & $<.072$ & $<.013$ & $<.37$ & $<.22$ & $<.29$ \\
\hline 17 & Medford & .....do. & $<.015$ & $<.021$ & $<.072$ & $<.013$ & $<.37$ & $<.22$ & $<.29$ \\
\hline 18 & .....do. & .....do. & $<.015$ & $<.021$ & $<.072$ & $<.013$ & $<.37$ & $<.22$ & $<.29$ \\
\hline 19 & .....do. & .....do. & $<.015$ & $<.021$ & $<.072$ & $<.013$ & $<.37$ & $<.22$ & $<.29$ \\
\hline 20 & .....do. & .....do. & $<.015$ & $<.021$ & $<.072$ & $<.013$ & $<.37$ & $<.22$ & $<.29$ \\
\hline 21 & .....do. & .....do. & $<.015$ & $<.021$ & $<.072$ & $<.013$ & $<.37$ & $<.22$ & $<.29$ \\
\hline 22 & .....do. & .....do. & $<.015$ & $<.021$ & $<.072$ & $<.013$ & $<.37$ & $<.22$ & $<.29$ \\
\hline 23 & .....do. & .....do. & $<.015$ & $<.021$ & $<.072$ & $<.013$ & $<.37$ & $<.22$ & $<.29$ \\
\hline 24 & .....do. & .....do. & $<.015$ & $<.021$ & $<.072$ & $<.013$ & $<.37$ & $<.22$ & $<.29$ \\
\hline 31 & .....do. & .....do. & $<.015$ & $<.021$ & $<.072$ & $<.013$ & $<.37$ & $<.22$ & $<.29$ \\
\hline 32 & .....do. & .....do. & $<.015$ & $<.021$ & $<.072$ & $<.013$ & $<.37$ & $<.22$ & $<.29$ \\
\hline 33 & .....do. & .....do. & $<.015$ & $<.021$ & $<.072$ & $<.013$ & $<.37$ & $<.22$ & $<.29$ \\
\hline 34 & .....do. & .....do. & $<.015$ & $<.021$ & $<.072$ & $<.013$ & $<.37$ & $<.22$ & $<.29$ \\
\hline 35 & .....do. & .....do. & $<.015$ & $<.021$ & $<.072$ & $<.013$ & $<.37$ & $<.22$ & $<.29$ \\
\hline 36 & .....do. & .....do. & $<.015$ & $<.021$ & $<.072$ & $<.013$ & $<.37$ & $<.22$ & $<.29$ \\
\hline 37 & Somerville & .....do. & $<.015$ & $<.021$ & $<.072$ & $<.013$ & $<.37$ & $<.22$ & $<.29$ \\
\hline 38 & Medford & .....do. & $<.015$ & $<.021$ & $<.072$ & $<.013$ & $<.37$ & $<.22$ & $<.29$ \\
\hline 39 & .....do. & .....do. & $<.015$ & $<.021$ & $<.072$ & $<.013$ & $<.37$ & $<.22$ & $<.29$ \\
\hline 40 & .....do. & .....do. & $<.015$ & $<.021$ & $<.072$ & $<.013$ & $<.37$ & $<.22$ & $<.29$ \\
\hline 41 & Everett & Upper Mystic River & $<.015$ & $<.021$ & $<.072$ & $<.013$ & $<.37$ & $<.22$ & 2.5 \\
\hline 42 & Malden & Malden River & $<.015$ & $<.021$ & $<.072$ & $<.013$ & $<.37$ & $<.22$ & $<.29$ \\
\hline 43 & .....do. & .....do. & $<.015$ & $<.021$ & $<.072$ & $<.013$ & 14 & $<.22$ & 45 \\
\hline 44 & .....do. & .....do. & $<.015$ & $<.021$ & $<.072$ & $<.013$ & 4.6 & 4.2 & 21 \\
\hline 45 & .....do. & .....do. & $<.015$ & $<.021$ & $<.072$ & $<.013$ & 13 & $<.22$ & 26 \\
\hline
\end{tabular}


Table 3. Distribution of element and organic compound concentrations measured in sediment grab samples, Mystic River Basin, Massachusetts.-Continued

[Station number: USGS sample identifiers and geographical coordinates are given in table 1; sampling locations shown on figure 3. BHC, 1,2,3,4,5,6-hexachlorocyclohexane; D, duplicate; DDD, dichlorodiphenyldichloroethane; DDE, dichlorodiphenyldichloroethylene; DDT, dichlorodiphenyltrichloro-ethane; do., ditto; LD, lab duplicate; No., number; PES, Performance Evaluation Standard; RPD, relative percent difference; USGS, U.S. Geological Survey; ppm, parts per million; \%, percent; <, actual value shown is less than the minimum reporting limit; *, PES reported value was less than detection; --, not analyzed]

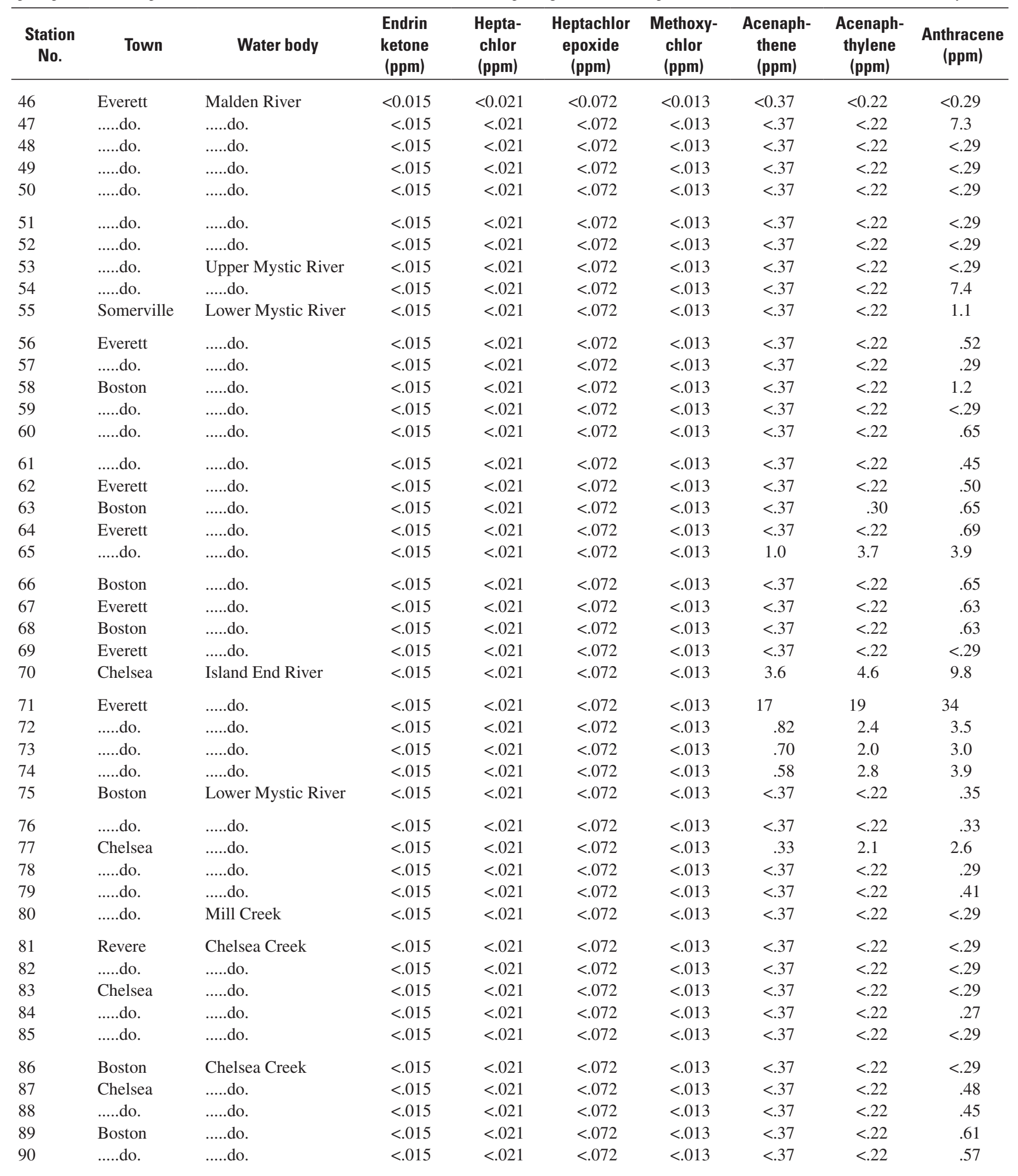


Table 3. Distribution of element and organic compound concentrations measured in sediment grab samples, Mystic River Basin, Massachusetts.-Continued

[Station number: USGS sample identifiers and geographical coordinates are given in table 1; sampling locations shown on figure 3. BHC, 1,2,3,4,5,6-hexachlorocyclohexane; D, duplicate; DDD, dichlorodiphenyldichloroethane; DDE, dichlorodiphenyldichloroethylene; DDT, dichlorodiphenyltrichloro-ethane; do., ditto; LD, lab duplicate; No., number; PES, Performance Evaluation Standard; RPD, relative percent difference; USGS, U.S. Geological Survey; ppm, parts per million; \%, percent; <, actual value shown is less than the minimum reporting limit; *, PES reported value was less than detection; --, not analyzed]

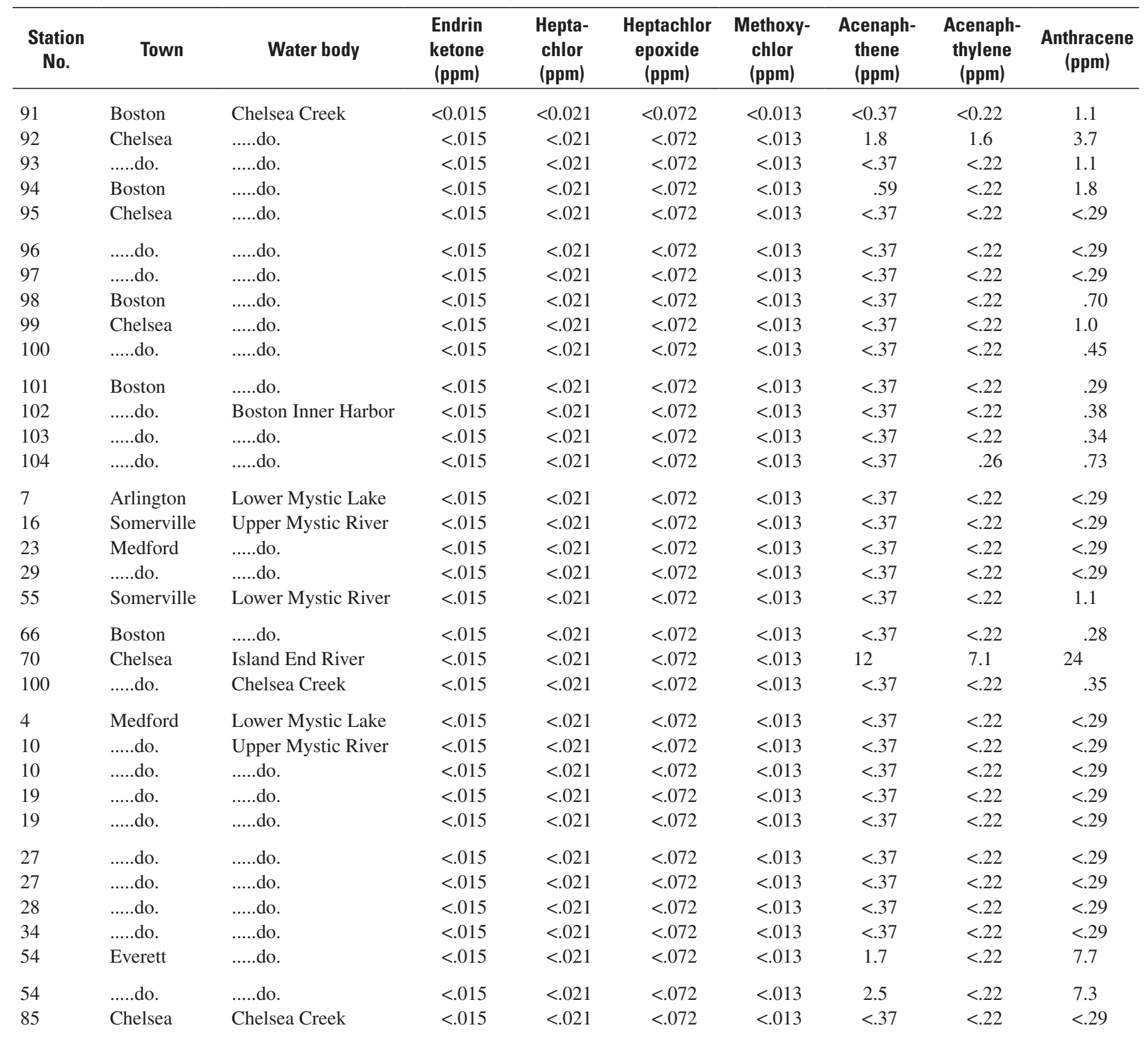


Table 3. Distribution of element and organic compound concentrations measured in sediment grab samples, Mystic River Basin, Massachusetts.-Continued

[Station number: USGS sample identifiers and geographical coordinates are given in table 1; sampling locations shown on figure 3. BHC, 1,2,3,4,5,6-hexachlorocyclohexane; D, duplicate; DDD, dichlorodiphenyldichloroethane; DDE, dichlorodiphenyldichloroethylene; DDT, dichlorodiphenyltrichloro-ethane; do., ditto; LD, lab duplicate; No., number; PES, Performance Evaluation Standard; RPD, relative percent difference; USGS, U.S. Geological Survey; ppm, parts per million; \%, percent; <, actual value shown is less than the minimum reporting limit; *, PES reported value was less than detection; --, not analyzed]

\begin{tabular}{|c|c|c|c|c|c|c|c|c|c|}
\hline $\begin{array}{c}\text { Station } \\
\text { No. }\end{array}$ & Town & Water body & $\begin{array}{c}\text { Benzo[a]- } \\
\text { anthracene } \\
\text { (ppm) }\end{array}$ & $\begin{array}{c}\text { Benzo }[b, k]- \\
\text { fluoranthra- } \\
\text { cene } \\
(\mathrm{ppm})\end{array}$ & $\begin{array}{c}\text { Benzo[a]- } \\
\text { pyrene } \\
\text { (ppm) }\end{array}$ & $\begin{array}{c}\text { Benzo }[g, h, i]- \\
\text { perylene } \\
\text { (ppm) }\end{array}$ & $\begin{array}{c}\text { Chrysene } \\
\text { (ppm) }\end{array}$ & $\begin{array}{c}\text { Dibenz }[a, h]- \\
\text { anthracene } \\
\text { (ppm) }\end{array}$ & $\begin{array}{c}\text { Fluoran- } \\
\text { thene } \\
\text { (ppm) }\end{array}$ \\
\hline 1 & Medford & Lower Mystic Lake & $<0.44$ & $<0.29$ & $<0.51$ & $<0.32$ & $<0.28$ & $<0.58$ & $<0.12$ \\
\hline 2 & Arlington & .....do. & $<.44$ & $<.29$ & $<.51$ & $<.32$ & $<.28$ & $<.58$ & $<.12$ \\
\hline 3 & .....do. & .....do. & $<.44$ & $<.29$ & $<.51$ & $<.32$ & $<.28$ & $<.58$ & $<.12$ \\
\hline 4 & Medford & .....do. & $<.44$ & 64 & 51 & $<.32$ & 66 & $<.58$ & 57 \\
\hline 5 & Arlington & .....do. & 27 & 38 & 33 & $<.32$ & 41 & $<.58$ & 63 \\
\hline 6 & .....do. & .....do. & 26 & 49 & 35 & 15 & 49 & $<.58$ & 66 \\
\hline 7 & .....do. & .....do. & 16 & 27 & 20 & $<.32$ & 23 & $<.58$ & 36 \\
\hline 8 & Medford & Upper Mystic River & $<.44$ & $<.29$ & $<.51$ & $<.32$ & $<.28$ & $<.58$ & $<.12$ \\
\hline 9 & .....do. & .....do. & $<.44$ & $<.29$ & $<.51$ & $<.32$ & $<.28$ & $<.58$ & 1.8 \\
\hline 10 & .....do. & .....do. & 2.9 & 7.4 & $<.51$ & $<.32$ & $<.28$ & $<.58$ & 6.8 \\
\hline 11 & Cambridge & Alewife Brook & 8.0 & 14 & 16 & 9.9 & 17 & $<.58$ & 21 \\
\hline 12 & .....do. & .....do. & $<.44$ & 1.5 & $<.51$ & $<.32$ & 1.4 & $<.58$ & 3.5 \\
\hline 13 & Somerville & .....do. & 29 & 26 & 32 & 17 & 42 & 8.6 & 70 \\
\hline 14 & .....do. & .....do. & 7.9 & 10 & 12 & $<.32$ & 12 & $<.58$ & 17 \\
\hline 15 & .....do. & .....do. & 11 & 14 & 16 & 15 & 18 & 8.7 & 23 \\
\hline 16 & .....do. & Upper Mystic River & 20 & 31 & 31 & 37 & 36 & 21 & 44 \\
\hline 17 & Medford & .....do. & $<.44$ & $<.29$ & $<.51$ & $<.32$ & $<.28$ & $<.58$ & $<.12$ \\
\hline 18 & .....do. & .....do. & $<.44$ & $<.29$ & $<.51$ & $<.32$ & $<.28$ & $<.58$ & $<.12$ \\
\hline 19 & .....do. & .....do. & 4.5 & 6.9 & 3.9 & $<.32$ & 5.5 & $<.58$ & 11 \\
\hline 20 & .....do. & .....do. & $<.44$ & $<.29$ & $<.51$ & $<.32$ & $<.28$ & $<.58$ & $<.12$ \\
\hline 21 & .....do. & .....do. & $<.44$ & $<.29$ & $<.51$ & $<.32$ & $<.28$ & $<.58$ & 8.6 \\
\hline 22 & .....do. & .....do. & 2.6 & 6.1 & 5.0 & $<.32$ & 6.1 & $<.58$ & 9 \\
\hline 23 & .....do. & .....do. & 17 & 26 & 26 & 24 & 31 & $<.58$ & 41 \\
\hline 24 & .....do. & .....do. & $<.44$ & $<.29$ & $<.51$ & $<.32$ & $<.28$ & $<.58$ & $<.12$ \\
\hline 25 & .....do. & .....do. & 3.8 & 5.8 & 6.1 & 3.9 & 6.1 & $<.58$ & 9.5 \\
\hline 26 & .....do. & .....do. & 15 & 25 & 24 & 23 & 26 & $<.58$ & 30 \\
\hline 27 & .....do. & .....do. & 5.4 & 6.1 & 6.6 & $<.32$ & 10 & $<.58$ & 13 \\
\hline 28 & .....do. & .....do. & $<.44$ & $<.29$ & $<.51$ & $<.32$ & $<.28$ & $<.58$ & 160 \\
\hline 29 & .....do. & .....do. & 18 & 26 & 27 & 27 & 29 & $<.58$ & 32 \\
\hline 30 & .....do. & .....do. & 16 & 25 & 26 & 22 & 27 & $<.58$ & 30 \\
\hline 31 & .....do. & .....do. & 13 & 22 & 24 & 22 & 24 & 15 & 26 \\
\hline 32 & .....do. & .....do. & 1.3 & 3.1 & 1.9 & $<.32$ & 4.1 & $<.58$ & 5.7 \\
\hline 33 & .....do. & .....do. & $<.44$ & $<.29$ & $<.51$ & $<.32$ & $<.28$ & $<.58$ & 5.3 \\
\hline 34 & .....do. & .....do. & 12 & 22 & 25 & 21 & 24 & $<.58$ & 25 \\
\hline 35 & .....do. & .....do. & 14 & 25 & 27 & 19 & 31 & $<.58$ & 34 \\
\hline 36 & .....do. & .....do. & 9.9 & 18 & 19 & 12 & 22 & $<.58$ & 24 \\
\hline 37 & Somerville & .....do. & 16 & 34 & 39 & 23 & 42 & $<.58$ & 32 \\
\hline 38 & Medford & .....do. & 9.7 & 19 & 21 & 14 & 22 & $<.58$ & 21 \\
\hline 39 & .....do. & .....do. & 9.1 & 16 & 16 & 9.3 & 19 & $<.58$ & 18 \\
\hline 40 & .....do. & .....do. & $<.44$ & 4.9 & $<.51$ & $<.32$ & $<.28$ & $<.58$ & 7.2 \\
\hline 41 & Everett & Upper Mystic River & 8.8 & 11 & 13 & 6.5 & 15 & $<.58$ & 16 \\
\hline 42 & Malden & Malden River & 4.9 & 5.8 & 3.9 & $<.32$ & 6.6 & $<.58$ & 14 \\
\hline 43 & .....do. & .....do. & 60 & 55 & 79 & 39 & 83 & 23 & 120 \\
\hline 44 & .....do. & .....do. & 55 & 61 & 74 & 62 & 77 & 23 & 110 \\
\hline 45 & .....do. & .....do. & 24 & 20 & 30 & 14 & 36 & $<.58$ & 48 \\
\hline
\end{tabular}


Table 3. Distribution of element and organic compound concentrations measured in sediment grab samples, Mystic River Basin, Massachusetts.-Continued

[Station number: USGS sample identifiers and geographical coordinates are given in table 1; sampling locations shown on figure 3. BHC, 1,2,3,4,5,6-hexachlorocyclohexane; D, duplicate; DDD, dichlorodiphenyldichloroethane; DDE, dichlorodiphenyldichloroethylene; DDT, dichlorodiphenyltrichloro-ethane; do., ditto; LD, lab duplicate; No., number; PES, Performance Evaluation Standard; RPD, relative percent difference; USGS, U.S. Geological Survey; ppm, parts per million; \%, percent; <, actual value shown is less than the minimum reporting limit; *, PES reported value was less than detection; --, not analyzed]

\begin{tabular}{|c|c|c|c|c|c|c|c|c|c|}
\hline $\begin{array}{c}\text { Station } \\
\text { No. }\end{array}$ & Town & Water body & $\begin{array}{l}\text { Benzo[a]- } \\
\text { anthracene } \\
(\mathrm{ppm})\end{array}$ & $\begin{array}{c}\text { Benzo }[\boldsymbol{b}, \boldsymbol{k}]- \\
\text { fluoranthra- } \\
\text { cene } \\
(\mathrm{ppm})\end{array}$ & $\begin{array}{c}\text { Benzo[a]- } \\
\text { pyrene } \\
\text { (ppm) }\end{array}$ & $\begin{array}{c}\text { Benzo }[g, h, i]- \\
\text { perylene } \\
\text { (ppm) }\end{array}$ & $\begin{array}{c}\text { Chrysene } \\
\text { (ppm) }\end{array}$ & $\begin{array}{c}\text { Dibenz }[a, h]- \\
\text { anthracene } \\
\text { (ppm) }\end{array}$ & $\begin{array}{c}\text { Fluoran- } \\
\text { thene } \\
\text { (ppm) }\end{array}$ \\
\hline 46 & Everett & Malden River & 23 & 36 & 42 & 43 & 38 & 11 & 30 \\
\hline 47 & .....do. & .....do. & 36 & 53 & 65 & 61 & 60 & 16 & 56 \\
\hline 48 & .....do. & .....do. & 22 & 39 & 45 & 36 & 44 & 15 & 51 \\
\hline 49 & .....do. & .....do. & 7.5 & 10 & 11 & 5.2 & 14 & $<.58$ & 15 \\
\hline 50 & .....do. & .....do. & $<.44$ & $<.29$ & $<.51$ & $<.32$ & $<.28$ & $<.58$ & $<.12$ \\
\hline 51 & .....do. & .....do. & 1.3 & 3.2 & 2.3 & $<.32$ & 3.9 & $<.58$ & 3.3 \\
\hline 52 & .....do. & .....do. & 18 & 12 & 24 & 7.0 & 19 & $<.58$ & 8.3 \\
\hline 53 & .....do. & Upper Mystic River & 7.8 & 16 & 15 & 7.7 & 19 & $<.58$ & 19 \\
\hline 54 & .....do. & .....do. & 10 & 23 & 23 & 16 & 25 & $<.58$ & 25 \\
\hline 55 & Somerville & Lower Mystic River & 2.4 & 5.7 & 4.0 & 3.3 & 5.4 & 1.3 & 10 \\
\hline 56 & Everett & .....do. & .85 & 2.6 & 1.9 & 1.3 & 2.3 & 1.2 & 2.9 \\
\hline 57 & ......do. & .....do. & .59 & .92 & .81 & $<.32$ & 1.0 & $<.58$ & 2.1 \\
\hline 58 & Boston & .....do. & 1.8 & 3.9 & 2.9 & 2.1 & 3.3 & .79 & 5.7 \\
\hline 59 & .....do. & .....do. & $<.44$ & 8.3 & .72 & .42 & .8 & $<.58$ & .85 \\
\hline 60 & .....do. & .....do. & .79 & 2.1 & 1.6 & 1.0 & 1.7 & 1.5 & 2.2 \\
\hline 61 & .....do. & .....do. & .98 & 2.0 & 1.8 & .61 & 1.8 & $<.58$ & 2.6 \\
\hline 62 & Everett & .....do. & .71 & 1.4 & 1.2 & .59 & 1.3 & $<.58$ & 1.5 \\
\hline 63 & Boston & .....do. & 1.0 & 2.1 & 1.7 & 1.3 & 1.6 & .46 & 2.2 \\
\hline 64 & Everett & .....do. & .97 & 2.2 & 2.0 & 1.1 & 1.9 & $<.58$ & 2.3 \\
\hline 65 & .....do. & .....do. & 5.4 & 6.0 & 6.1 & 3.2 & 7.4 & 2.4 & 14 \\
\hline 66 & Boston & .....do. & .88 & 2.0 & 1.7 & 1.2 & 1.6 & $<.58$ & 1.8 \\
\hline 67 & Everett & .....do. & .96 & 1.8 & 1.4 & .94 & 1.4 & $<.58$ & 2 \\
\hline 68 & Boston & .....do. & 1.1 & 2.3 & 2.0 & 1.3 & 1.8 & $<.58$ & 2.3 \\
\hline 69 & Everett & .....do. & .65 & 1.4 & 1.1 & $<.32$ & 1.1 & $<.58$ & 1.6 \\
\hline 70 & Chelsea & Island End River & 14 & 24 & 19 & 14 & 21 & 5.5 & 46 \\
\hline 71 & Everett & .....do. & 40 & 48 & 42 & 23 & 45 & 12 & 120 \\
\hline 72 & .....do. & .....do. & 4.4 & 8.0 & 7.0 & 4.0 & 6.1 & 1.8 & 12 \\
\hline 73 & .....do. & .....do. & 4.0 & 6.6 & 5.9 & 5.4 & 6.0 & 1.6 & 9.4 \\
\hline 74 & .....do. & .....do. & 5.1 & 8.5 & 7.8 & 4.5 & 7.3 & 2.2 & 11 \\
\hline 75 & Boston & Lower Mystic River & .51 & 1.3 & 1.1 & .49 & 1.0 & $<.58$ & 1.5 \\
\hline 76 & .....do. & .....do. & .76 & 1.7 & 1.6 & .91 & 1.2 & $<.58$ & 1.5 \\
\hline 77 & Chelsea & .....do. & 4.5 & 7.3 & 6.8 & 4.2 & 6.7 & 2.1 & 9.3 \\
\hline 78 & .....do. & .....do. & .62 & 1.4 & 1.2 & .71 & 1.2 & $<.58$ & 1.4 \\
\hline 79 & .....do. & .....do. & .97 & 1.4 & 1.4 & .71 & 1.4 & $<.58$ & 2.0 \\
\hline 80 & .....do. & Mill Creek & 1.4 & 4.5 & 3.8 & 1.9 & 4.0 & .84 & 5.7 \\
\hline 81 & Revere & Chelsea Creek & $<.44$ & .11 & .87 & $<.32$ & 1.1 & $<.58$ & 1.5 \\
\hline 82 & .....do. & .....do. & $<.44$ & $<.29$ & $<.51$ & $<.32$ & $<.28$ & $<.58$ & .17 \\
\hline 83 & Chelsea & .....do. & $<.44$ & $<.29$ & $<.51$ & $<.32$ & $<.28$ & $<.58$ & $<.12$ \\
\hline 84 & .....do. & .....do. & .43 & 1.2 & .92 & .43 & .96 & $<.58$ & 1.4 \\
\hline 85 & .....do. & .....do. & $<.44$ & .98 & .89 & .42 & 1.0 & $<.58$ & 1.2 \\
\hline 86 & Boston & .....do. & .39 & .85 & .82 & $<.32$ & .89 & $<.58$ & .86 \\
\hline 87 & Chelsea & .....do. & .61 & 1.2 & 1.0 & .59 & 1.1 & $<.58$ & 1.6 \\
\hline 88 & .....do. & .....do. & .68 & 1.4 & 1.1 & .63 & 1.3 & $<.58$ & 4.3 \\
\hline 89 & Boston & .....do. & 1.0 & 1.8 & 1.7 & .83 & 1.7 & $<.58$ & 2.6 \\
\hline 90 & .....do. & .....do. & .83 & 1.6 & 1.7 & .71 & 1.4 & $<.58$ & 1.6 \\
\hline
\end{tabular}


Table 3. Distribution of element and organic compound concentrations measured in sediment grab samples, Mystic River Basin, Massachusetts.-Continued

[Station number: USGS sample identifiers and geographical coordinates are given in table 1; sampling locations shown on figure 3. BHC, 1,2,3,4,5,6-hexachlorocyclohexane; D, duplicate; DDD, dichlorodiphenyldichloroethane; DDE, dichlorodiphenyldichloroethylene; DDT, dichlorodiphenyltrichloro-ethane; do., ditto; LD, lab duplicate; No., number; PES, Performance Evaluation Standard; RPD, relative percent difference; USGS, U.S. Geological Survey; ppm, parts per million; \%, percent; <, actual value shown is less than the minimum reporting limit; *, PES reported value was less than detection; --, not analyzed]

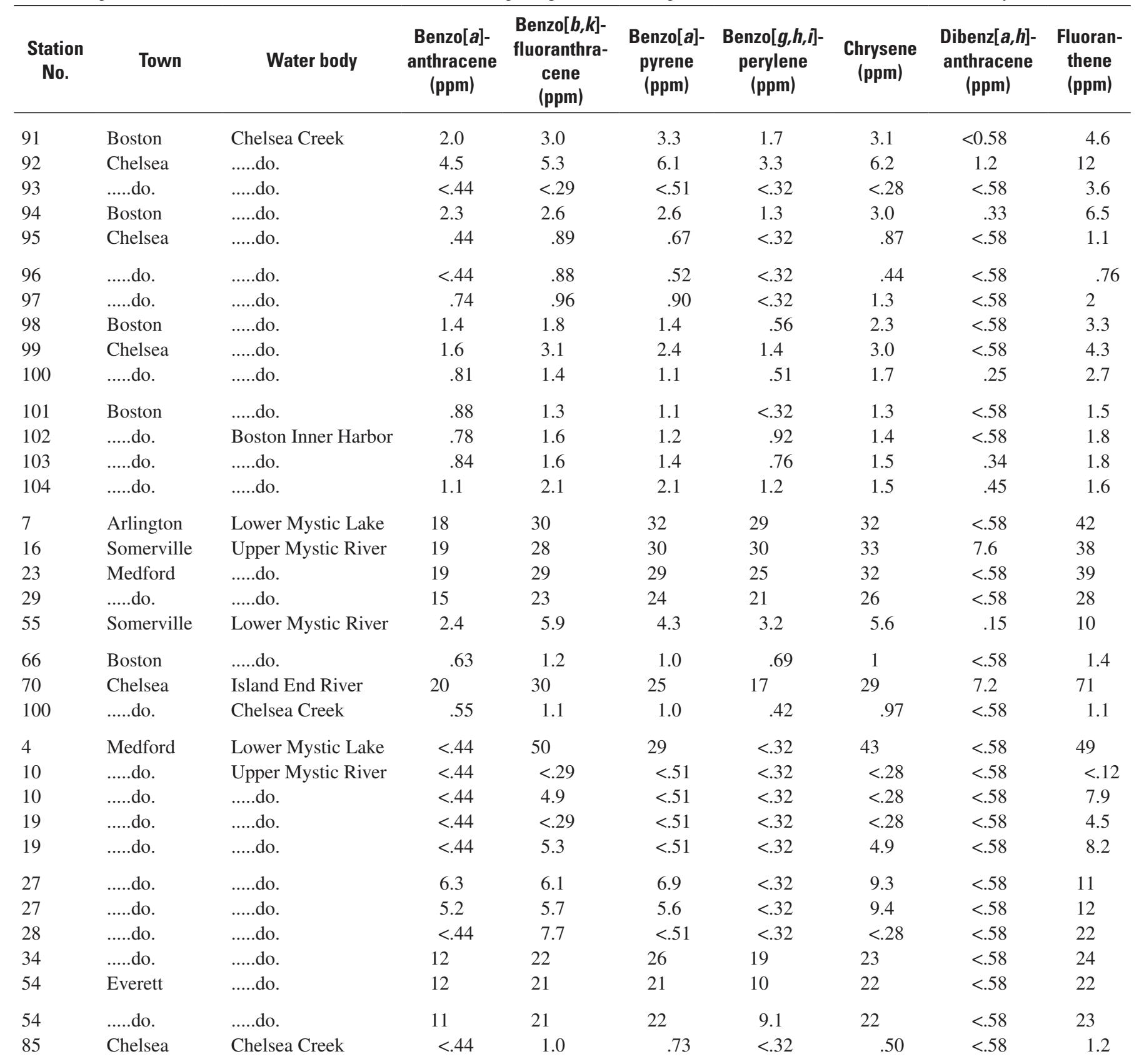


Table 3. Distribution of element and organic compound concentrations measured in sediment grab samples, Mystic River Basin, Massachusetts.-Continued

[Station number: USGS sample identifiers and geographical coordinates are given in table 1; sampling locations shown on figure 3. BHC, 1,2,3,4,5,6-hexachlorocyclohexane; D, duplicate; DDD, dichlorodiphenyldichloroethane; DDE, dichlorodiphenyldichloroethylene; DDT, dichlorodiphenyltrichloro-ethane; do., ditto; LD, lab duplicate; No., number; PES, Performance Evaluation Standard; RPD, relative percent difference; USGS, U.S. Geological Survey; ppm, parts per million; \%, percent; <, actual value shown is less than the minimum reporting limit; *, PES reported value was less than detection; --, not analyzed]

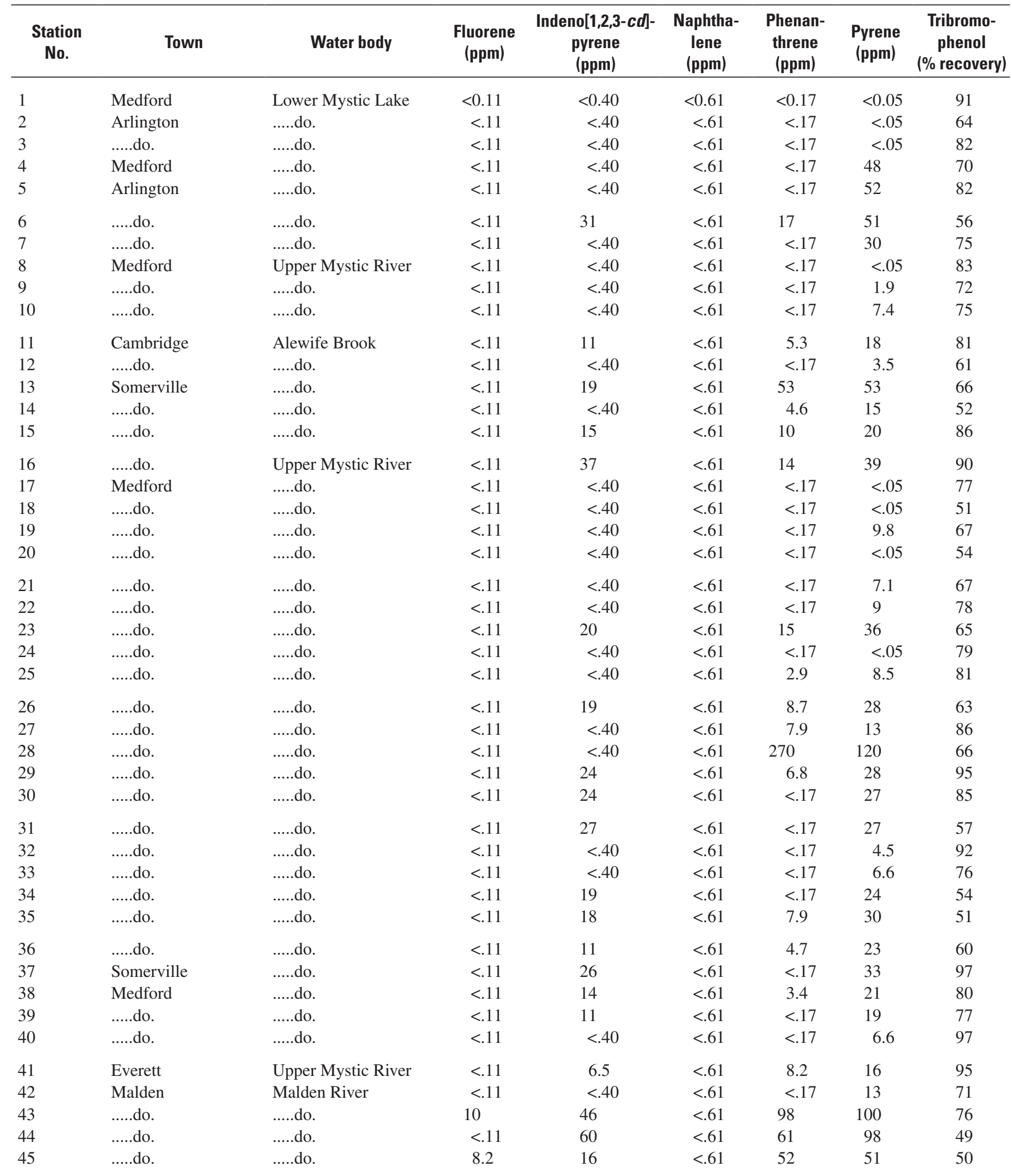


Table 3. Distribution of element and organic compound concentrations measured in sediment grab samples, Mystic River Basin, Massachusetts.-Continued

[Station number: USGS sample identifiers and geographical coordinates are given in table 1; sampling locations shown on figure 3. BHC, 1,2,3,4,5,6-hexachlorocyclohexane; D, duplicate; DDD, dichlorodiphenyldichloroethane; DDE, dichlorodiphenyldichloroethylene; DDT, dichlorodiphenyltrichloro-ethane; do., ditto; LD, lab duplicate; No., number; PES, Performance Evaluation Standard; RPD, relative percent difference; USGS, U.S. Geological Survey; ppm, parts per million; \%, percent; <, actual value shown is less than the minimum reporting limit; *, PES reported value was less than detection; --, not analyzed]

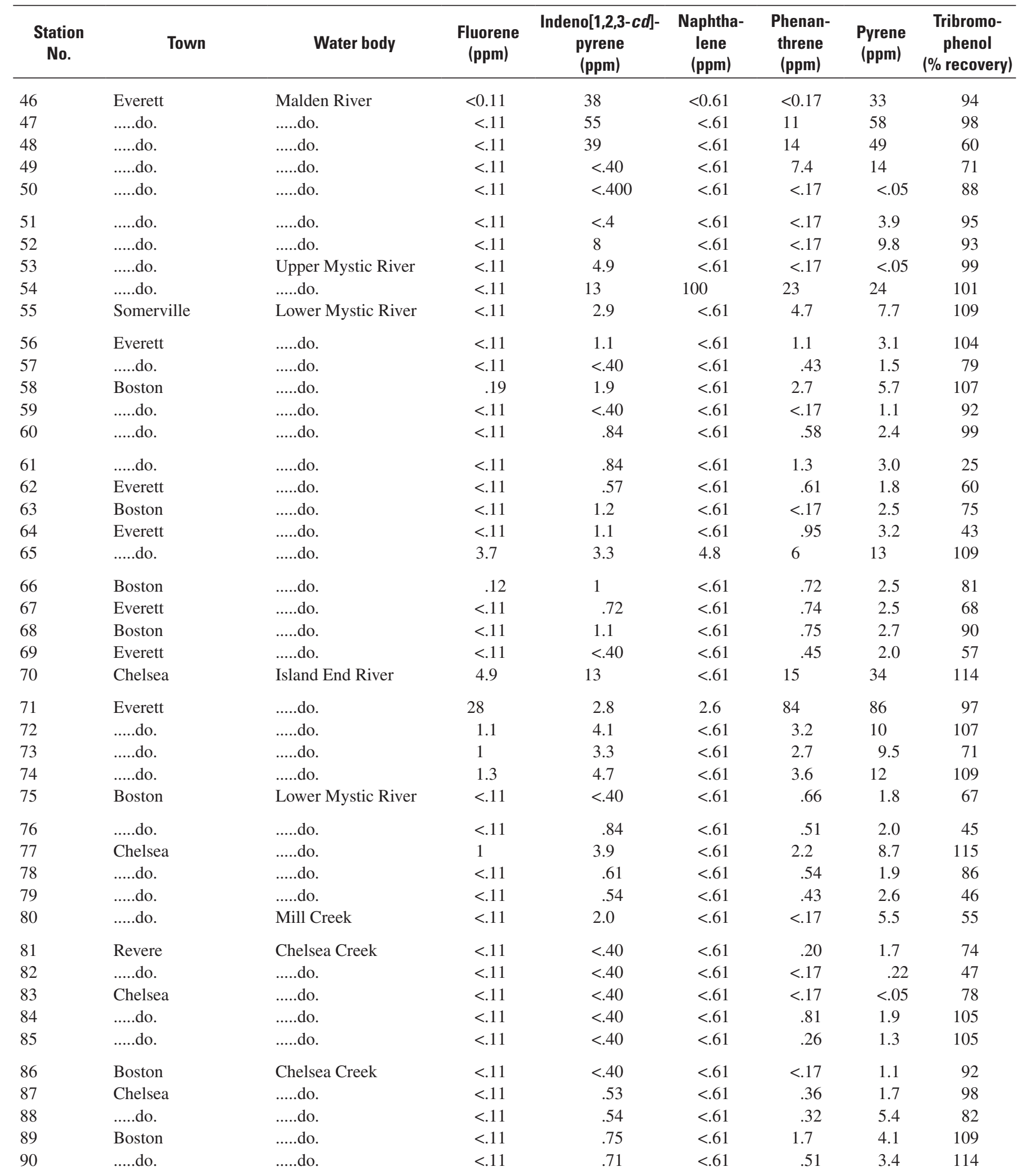


Table 3. Distribution of element and organic compound concentrations measured in sediment grab samples, Mystic River Basin, Massachusetts.-Continued

[Station number: USGS sample identifiers and geographical coordinates are given in table 1; sampling locations shown on figure 3. BHC, 1,2,3,4,5,6-hexachlorocyclohexane; D, duplicate; DDD, dichlorodiphenyldichloroethane; DDE, dichlorodiphenyldichloroethylene; DDT, dichlorodiphenyltrichloro-ethane; do., ditto; LD, lab duplicate; No., number; PES, Performance Evaluation Standard; RPD, relative percent difference; USGS, U.S. Geological Survey; ppm, parts per million; \%, percent; <, actual value shown is less than the minimum reporting limit; *, PES reported value was less than detection; --, not analyzed]

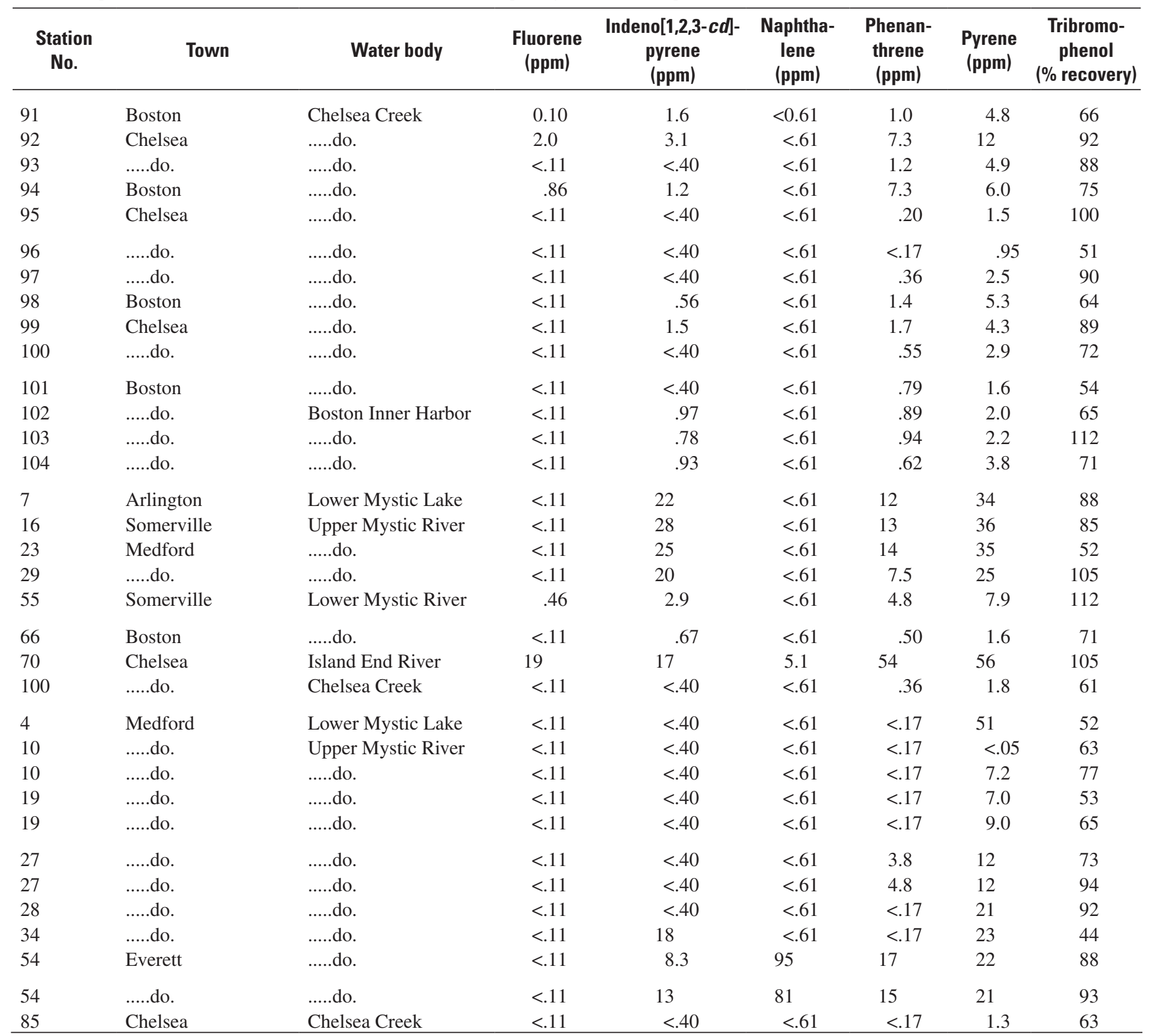


Table 4. Distribution of element concentrations measured in sediment core samples, Mystic River Basin, Massachusetts.

[Station number: USGS sample identifiers and geographical coordinates are given in table 1; sampling locations shown on figure 3. D, duplicate; do., ditto; No., number; cm, centimeters; ppm, parts per million; \%, percent; <, actual value shown is less than the minimum reporting limit; --, not analyzed]

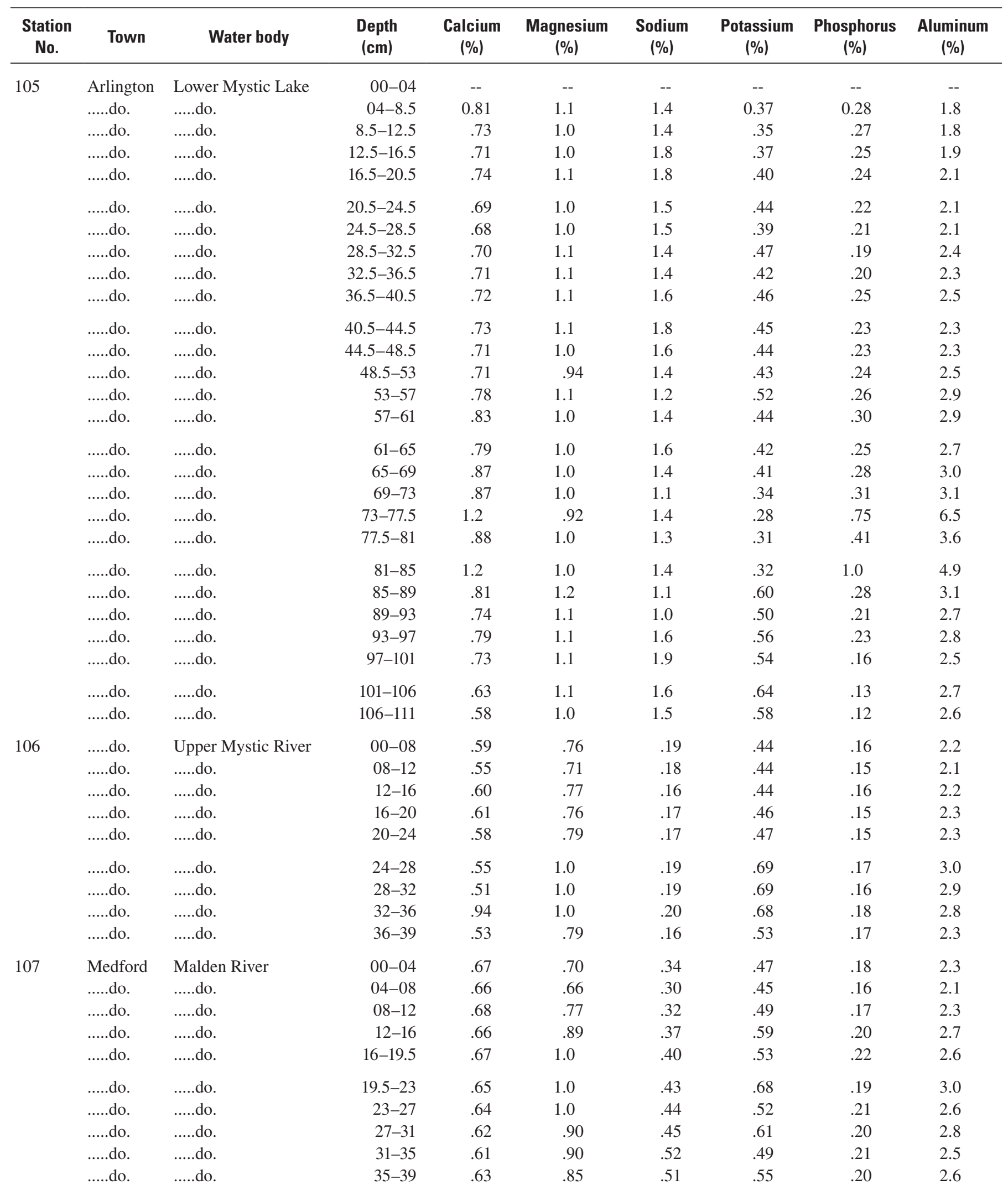


Table 4. Distribution of element concentrations measured in sediment core samples, Mystic River Basin, Massachusetts.—Continued

[Station number: USGS sample identifiers and geographical coordinates are given in table 1; sampling locations shown on figure 3. D, duplicate; do., ditto; No., number; cm, centimeters; ppm, parts per million; \%, percent; <, actual value shown is less than the minimum reporting limit; --, not analyzed]

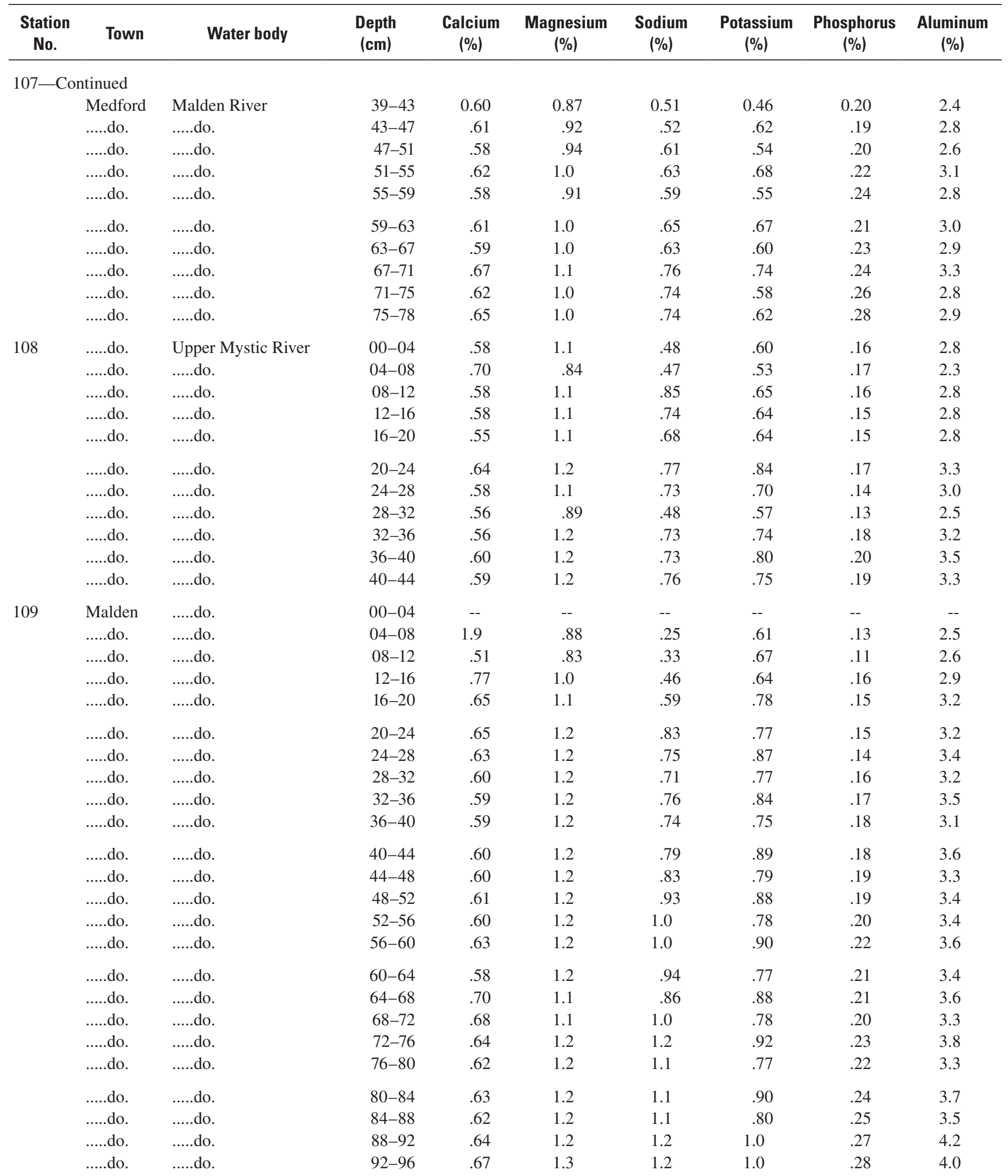


Table 4. Distribution of element concentrations measured in sediment core samples, Mystic River Basin, Massachusetts.—Continued

[Station number: USGS sample identifiers and geographical coordinates are given in table 1; sampling locations shown on figure 3. D, duplicate; do., ditto; No., number; cm, centimeters; ppm, parts per million; \%, percent; <, actual value shown is less than the minimum reporting limit; --, not analyzed]

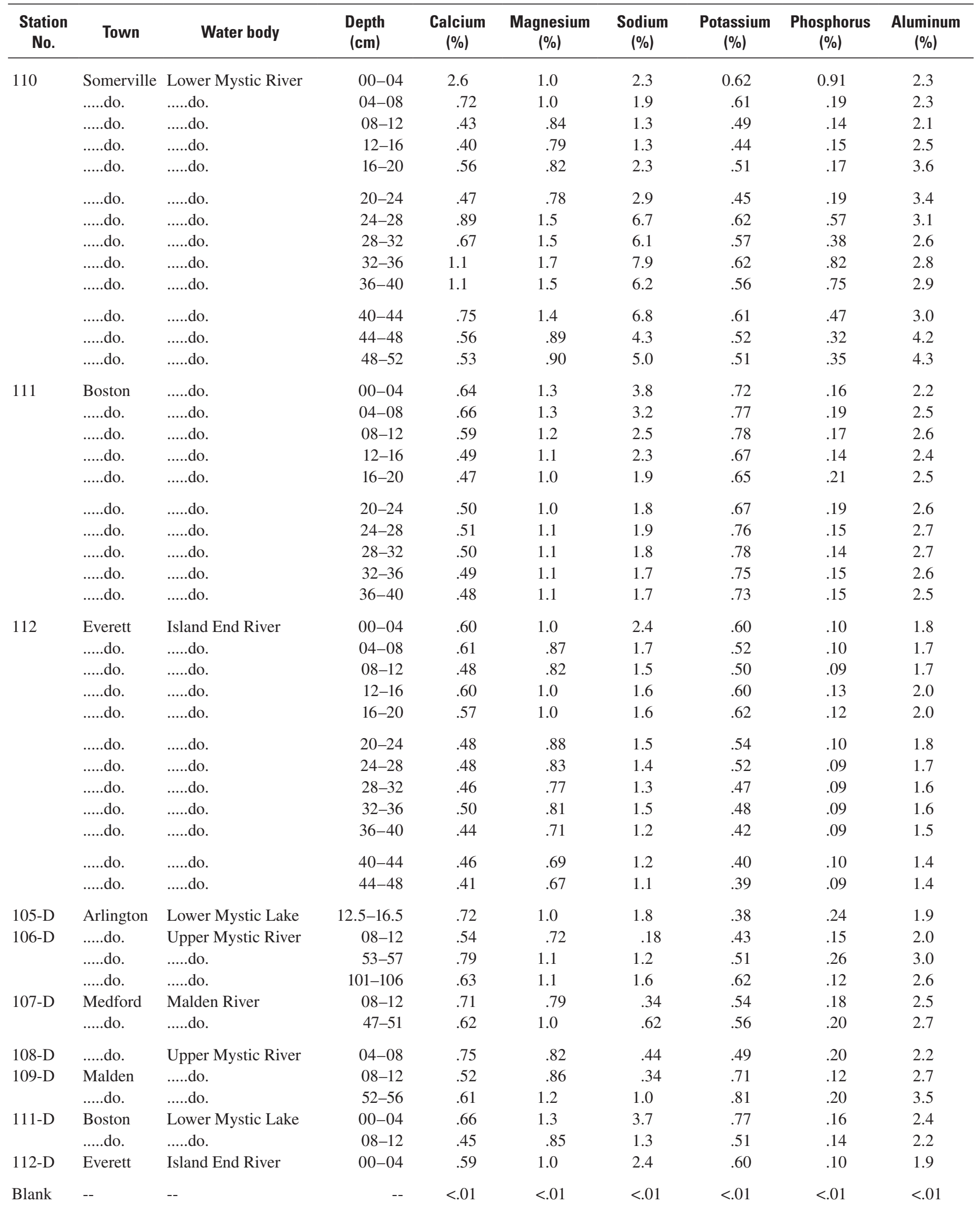


Table 4. Distribution of element concentrations measured in sediment core samples, Mystic River Basin, Massachusetts.-Continued

[Station number: USGS sample identifiers and geographical coordinates are given in table 1; sampling locations shown on figure 3. D, duplicate; do., ditto; No., number; cm, centimeters; ppm, parts per million; \%, percent; <, actual value shown is less than the minimum reporting limit; --, not analyzed

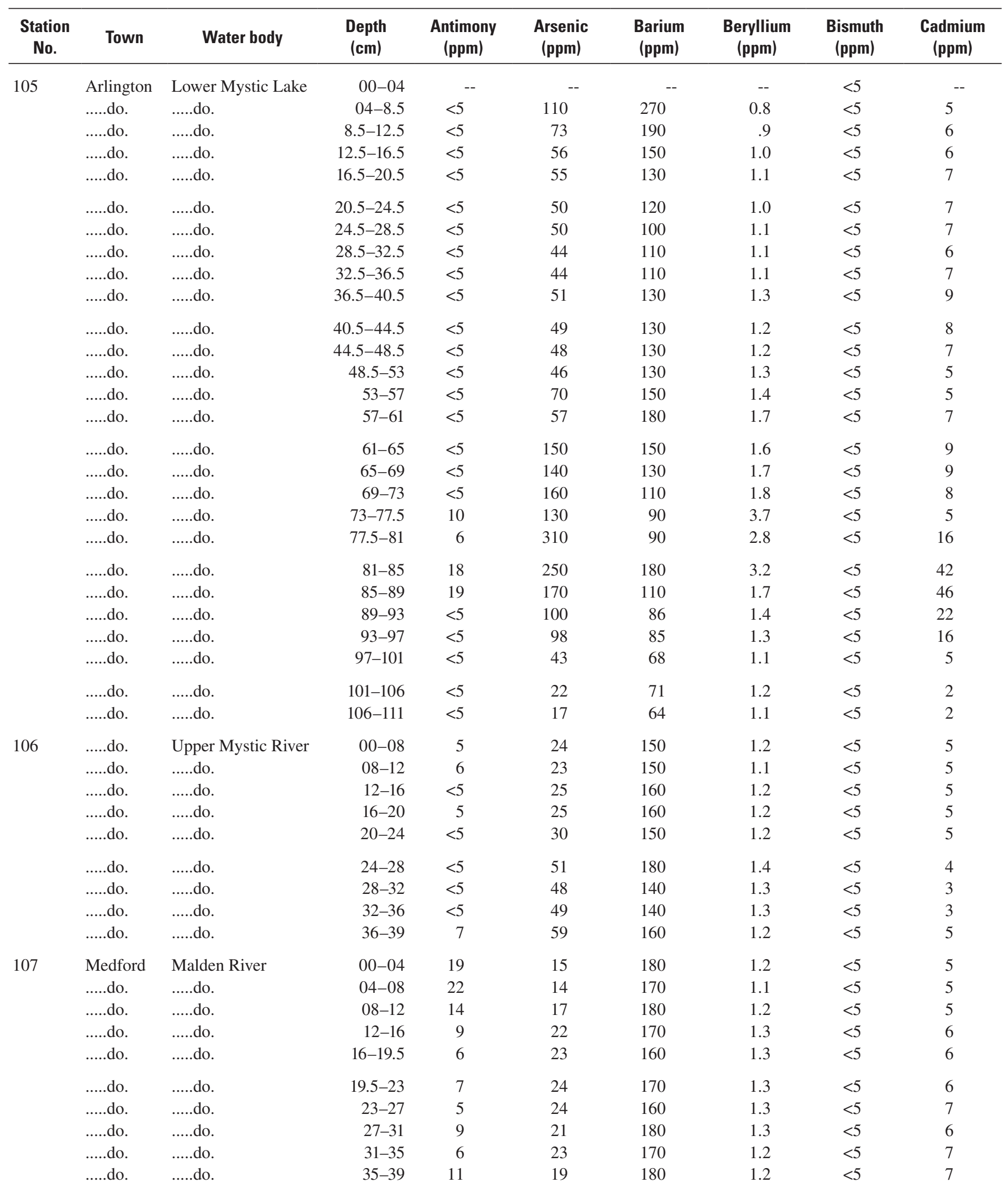


Table 4. Distribution of element concentrations measured in sediment core samples, Mystic River Basin, Massachusetts.—Continued

[Station number: USGS sample identifiers and geographical coordinates are given in table 1; sampling locations shown on figure 3. D, duplicate; do., ditto; No., number; cm, centimeters; ppm, parts per million; \%, percent; <, actual value shown is less than the minimum reporting limit; --, not analyzed

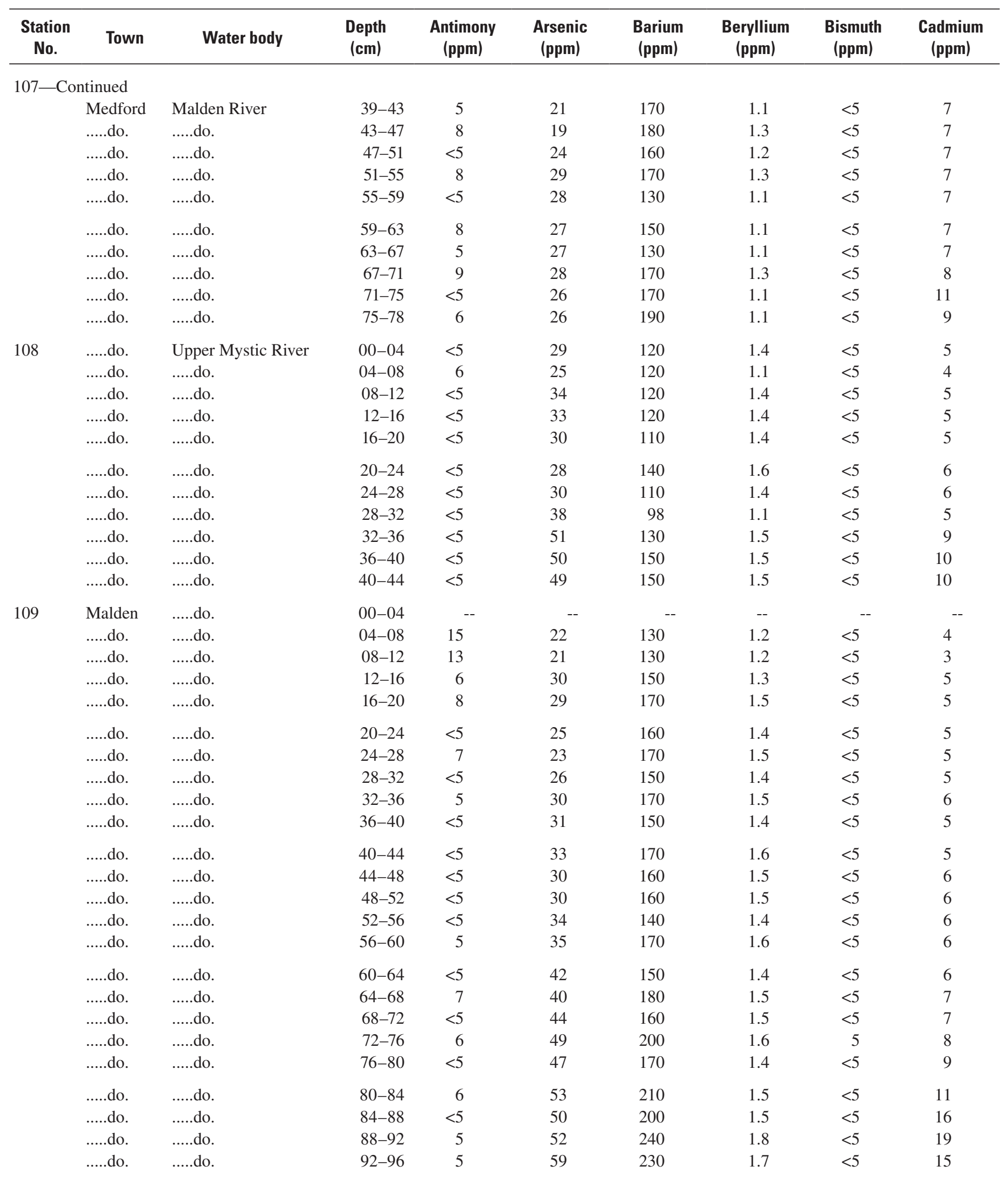


Table 4. Distribution of element concentrations measured in sediment core samples, Mystic River Basin, Massachusetts.-Continued

[Station number: USGS sample identifiers and geographical coordinates are given in table 1; sampling locations shown on figure 3. D, duplicate; do., ditto; No., number; cm, centimeters; ppm, parts per million; \%, percent; <, actual value shown is less than the minimum reporting limit; --, not analyzed

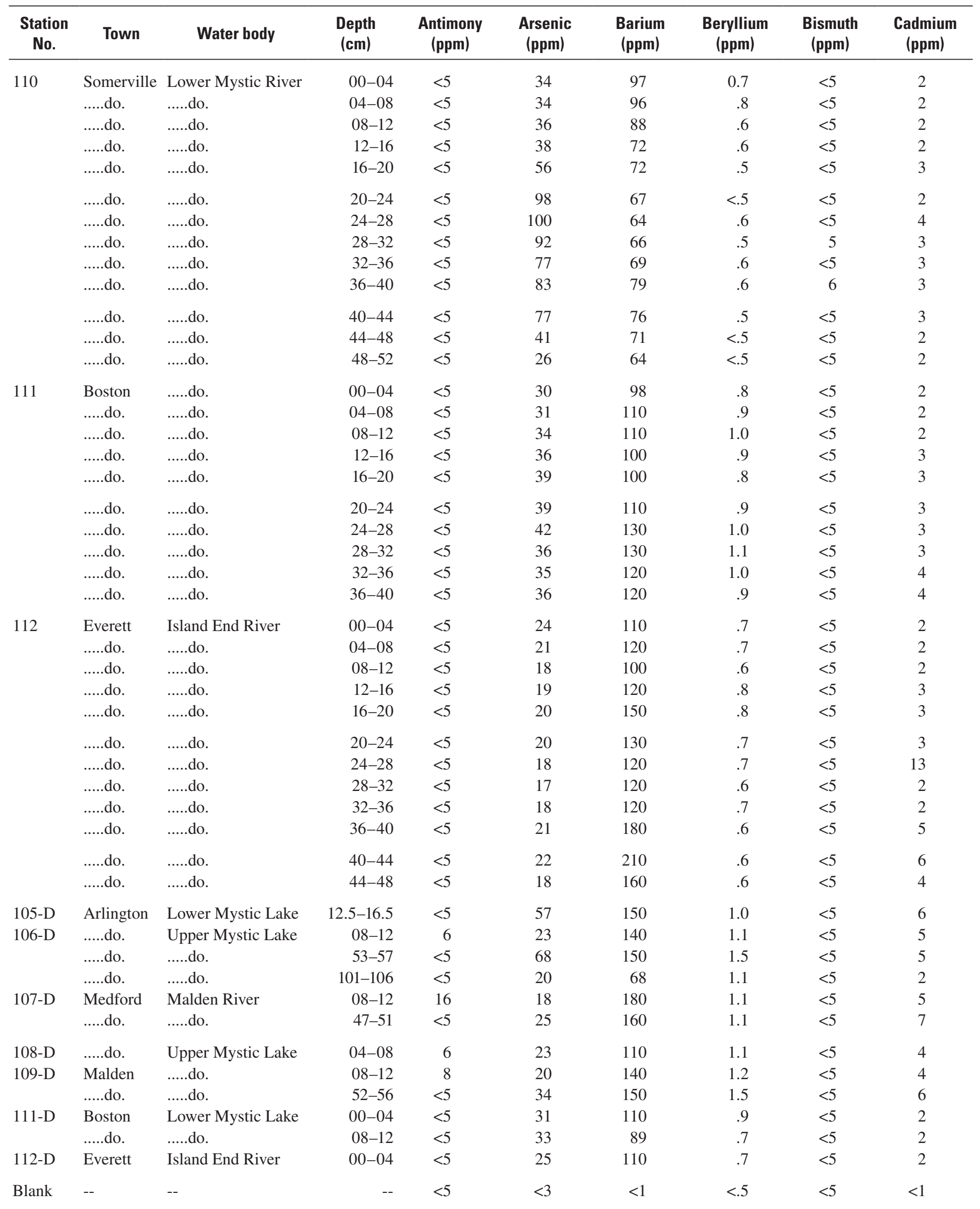


Table 4. Distribution of element concentrations measured in sediment core samples, Mystic River Basin, Massachusetts.—Continued

[Station number: USGS sample identifiers and geographical coordinates are given in table 1; sampling locations shown on figure 3. D, duplicate; do., ditto; No., number; cm, centimeters; ppm, parts per million; \%, percent; <, actual value shown is less than the minimum reporting limit; --, not analyzed]

\begin{tabular}{|c|c|c|c|c|c|c|c|c|c|c|}
\hline $\begin{array}{c}\text { Station } \\
\text { No. }\end{array}$ & Town & Water body & $\begin{array}{l}\text { Depth } \\
\text { (cm) }\end{array}$ & $\begin{array}{l}\text { Chromium } \\
\text { (ppm) }\end{array}$ & $\begin{array}{l}\text { Cobalt } \\
\text { (ppm) }\end{array}$ & $\begin{array}{c}\text { Copper } \\
\text { (ppm) }\end{array}$ & $\begin{array}{l}\text { Iron } \\
(\%)\end{array}$ & $\begin{array}{l}\text { Lanthanum } \\
\text { (ppm) }\end{array}$ & $\begin{array}{l}\text { Lead } \\
\text { (ppm) }\end{array}$ & $\begin{array}{c}\text { Lithium } \\
\text { (ppm) }\end{array}$ \\
\hline \multirow[t]{19}{*}{105} & Arlington & Lower Mystic Lake & 00-04 & -- & -- & -- & -- & -- & -- & -- \\
\hline & .....do. & .....do. & $8.5-12.5$ & 200 & 23 & 280 & 6.8 & 19 & 520 & 25 \\
\hline & .....do. & .....do. & $12.5-16.5$ & 360 & 23 & 310 & 5.9 & 20 & 580 & 25 \\
\hline & .....do. & .....do. & $16.5-20.5$ & 360 & 22 & 310 & 5.5 & 21 & 740 & 28 \\
\hline & .....do. & .....do. & $24.5-28.5$ & 330 & 22 & 330 & 5.0 & 22 & 1,200 & 30 \\
\hline & .....do. & .....do. & $28.5-32.5$ & 380 & 23 & 290 & 5.4 & 24 & 1,400 & 36 \\
\hline & .....do. & .....do. & $32.5-36.5$ & 310 & 24 & 300 & 5.0 & 23 & 1,600 & 34 \\
\hline & .....do. & .....do. & $36.5-40.5$ & 400 & 31 & 350 & 5.4 & 24 & 1,500 & 37 \\
\hline & .....do. & .....do. & $40.5-44.5$ & 420 & 24 & 340 & 5.3 & 23 & 1,300 & 37 \\
\hline & .....do. & .....do. & $57-61$ & 340 & 27 & 300 & 5.0 & 24 & 940 & 37 \\
\hline & .....do. & .....do. & $61-65$ & 360 & 39 & 390 & 5.0 & 25 & 980 & 33 \\
\hline & .....do. & .....do. & $65-69$ & 390 & 62 & 480 & 5.2 & 27 & 790 & 38 \\
\hline & .....do. & .....do. & 69-73 & 360 & 48 & 630 & 5.2 & 30 & 580 & 38 \\
\hline & .....do. & .....do. & $73-77.5$ & 1,100 & 18 & 4,200 & 5.3 & 51 & 1,300 & 27 \\
\hline & .....do. & .....do. & $77.5-81$ & 610 & 78 & 1,700 & 6.3 & 50 & 700 & 37 \\
\hline & .....do. & .....do. & $81-85$ & 1,800 & 32 & 4,200 & 8.6 & 51 & 1,700 & 31 \\
\hline & .....do. & .....do. & $85-89$ & 1,900 & 44 & 1,100 & 4.8 & 35 & 380 & 45 \\
\hline & .....do. & .....do. & $89-93$ & 650 & 24 & 590 & 4.4 & 26 & 300 & 37 \\
\hline & .....do. & .....do. & 93-97 & 350 & 24 & 500 & 4.3 & 25 & 320 & 36 \\
\hline \multirow{6}{*}{106} & .....do. & .....do. & $16-20$ & 440 & 16 & 250 & 3.9 & 23 & 400 & 37 \\
\hline & .....do. & .....do. & $20-24$ & 410 & 15 & 230 & 3.9 & 23 & 420 & 39 \\
\hline & .....do. & .....do. & $24-28$ & 310 & 15 & 200 & 4.4 & 25 & 350 & 50 \\
\hline & .....do. & .....do. & $28-32$ & 250 & 14 & 160 & 4.2 & 24 & 270 & 49 \\
\hline & .....do. & .....do. & $32-36$ & 250 & 14 & 180 & 4.3 & 23 & 300 & 48 \\
\hline & ......do. & ......do. & $36-39$ & 650 & 12 & 210 & 4.5 & 21 & 380 & 40 \\
\hline \multirow[t]{10}{*}{107} & Medford & Malden River & 00-04 & 1,800 & 17 & 250 & 4.9 & 24 & 580 & 27 \\
\hline & .....do. & .....do. & 04-08 & 2,100 & 17 & 230 & 4.9 & 22 & 550 & 25 \\
\hline & .....do. & .....do. & $08-12$ & 1,500 & 16 & 250 & 4.9 & 24 & 580 & 31 \\
\hline & .....do. & .....do. & $12-16$ & 960 & 16 & 270 & 5.2 & 25 & 600 & 39 \\
\hline & .....do. & .....do. & $16-19.5$ & 650 & 16 & 270 & 5.3 & 26 & 640 & 41 \\
\hline & .....do. & .....do. & $19.5-23$ & 810 & 17 & 290 & 5.6 & 26 & 640 & 45 \\
\hline & .....do. & .....do. & $23-27$ & 620 & 17 & 310 & 5.2 & 25 & 740 & 41 \\
\hline & .....do. & .....do. & 27-31 & 1,000 & 17 & 280 & 5.1 & 25 & 700 & 39 \\
\hline & .....do. & .....do. & $31-35$ & 570 & 18 & 280 & 4.7 & 23 & 810 & 37 \\
\hline & .....do. & .....do. & 35-39 & 1,100 & 18 & 270 & 4.7 & 25 & 780 & 35 \\
\hline
\end{tabular}


Table 4. Distribution of element concentrations measured in sediment core samples, Mystic River Basin, Massachusetts.-Continued

[Station number: USGS sample identifiers and geographical coordinates are given in table 1; sampling locations shown on figure 3. D, duplicate; do., ditto; No., number; cm, centimeters; ppm, parts per million; \%, percent; <, actual value shown is less than the minimum reporting limit; --, not analyzed]

\begin{tabular}{|c|c|c|c|c|c|c|c|c|c|c|}
\hline $\begin{array}{c}\text { Station } \\
\text { No. }\end{array}$ & Town & Water body & $\begin{array}{l}\text { Depth } \\
\text { (cm) }\end{array}$ & $\begin{array}{c}\text { Chromium } \\
\text { (ppm) }\end{array}$ & $\begin{array}{l}\text { Cobalt } \\
\text { (ppm) }\end{array}$ & $\begin{array}{c}\text { Copper } \\
\text { (ppm) }\end{array}$ & $\begin{array}{l}\text { Iron } \\
(\%)\end{array}$ & $\begin{array}{l}\text { Lanthanum } \\
\text { (ppm) }\end{array}$ & $\begin{array}{l}\text { Lead } \\
\text { (ppm) }\end{array}$ & $\begin{array}{c}\text { Lithium } \\
\text { (ppm) }\end{array}$ \\
\hline \multicolumn{11}{|c|}{ 107-Continued } \\
\hline & .....do. & .....do. & $43-47$ & 840 & 17 & 260 & 4.6 & 25 & 820 & 39 \\
\hline & .....do. & .....do. & $47-51$ & 500 & 17 & 280 & 4.8 & 24 & 810 & 41 \\
\hline & .....do. & .....do. & $51-55$ & 860 & 18 & 300 & 4.9 & 25 & 850 & 47 \\
\hline & .....do. & .....do. & $59-63$ & 840 & 19 & 270 & 4.8 & 25 & 820 & 47 \\
\hline & .....do. & .....do. & $63-67$ & 530 & 17 & 270 & 4.6 & 25 & 820 & 49 \\
\hline & .....do. & .....do. & $67-71$ & 940 & 18 & 290 & 5.3 & 27 & 1,000 & 51 \\
\hline & .....do. & .....do. & $71-75$ & 460 & 17 & 310 & 4.6 & 24 & 1,100 & 46 \\
\hline & ......do. & ......do. & $75-78$ & 670 & 17 & 310 & 4.6 & 25 & 1,200 & 44 \\
\hline \multirow{8}{*}{108} & .....do. & .....do. & $12-16$ & 230 & 16 & 280 & 5.6 & 24 & 440 & 49 \\
\hline & ......do. & ......do. & $16-20$ & 220 & 17 & 280 & 5.6 & 23 & 440 & 50 \\
\hline & .....do. & .....do. & $20-24$ & 400 & 18 & 300 & 6.0 & 25 & 480 & 56 \\
\hline & .....do. & .....do. & $24-28$ & 230 & 19 & 290 & 5.6 & 24 & 500 & 54 \\
\hline & .....do. & .....do. & $28-32$ & 380 & 16 & 200 & 4.2 & 20 & 400 & 45 \\
\hline & .....do. & .....do. & $32-36$ & 280 & 25 & 330 & 5.9 & 24 & 810 & 56 \\
\hline & .....do. & .....do. & $36-40$ & 480 & 27 & 340 & 6.2 & 24 & 770 & 58 \\
\hline & .....do. & .....do. & $40-44$ & 320 & 24 & 340 & 5.4 & 25 & 800 & 55 \\
\hline \multirow[t]{17}{*}{109} & Malden & .....do. & 00-04 & -- & -- & -- & -- & -- & -- & -- \\
\hline & .....do. & .....do. & 04-08 & 680 & 15 & 220 & 4.8 & 21 & 390 & 38 \\
\hline & ......do. & ......do. & $36-40$ & 300 & 19 & 260 & 5.7 & 25 & 550 & 53 \\
\hline & .....do. & .....do. & $40-44$ & 410 & 19 & 270 & 6.0 & 27 & 540 & 56 \\
\hline & .....do. & .....do. & $44-48$ & 290 & 19 & 310 & 5.6 & 26 & 600 & 55 \\
\hline & .....do. & .....do. & $48-52$ & 390 & 20 & 280 & 5.7 & 26 & 640 & 56 \\
\hline & .....do. & .....do. & $52-56$ & 320 & 23 & 290 & 5.8 & 25 & 780 & 57 \\
\hline & .....do. & .....do. & $56-60$ & 600 & 31 & 280 & 5.9 & 26 & 840 & 57 \\
\hline & .....do. & .....do. & $60-64$ & 320 & 29 & 270 & 5.6 & 25 & 880 & 55 \\
\hline & .....do. & .....do. & $64-68$ & 730 & 23 & 260 & 5.7 & 25 & 730 & 51 \\
\hline & .....do. & .....do. & $68-72$ & 340 & 26 & 260 & 5.7 & 24 & 760 & 50 \\
\hline & .....do. & .....do. & $72-76$ & 570 & 27 & 280 & 6.2 & 25 & 830 & 54 \\
\hline & .....do. & .....do. & $76-80$ & 340 & 25 & 290 & 5.9 & 24 & 830 & 50 \\
\hline & .....do. & .....do. & $80-84$ & 580 & 27 & 310 & 6.0 & 25 & 870 & 54 \\
\hline & .....do. & .....do. & $84-88$ & 410 & 22 & 350 & 5.2 & 25 & 870 & 53 \\
\hline & .....do. & .....do. & $88-92$ & 630 & 22 & 400 & 5.6 & 28 & 910 & 55 \\
\hline & .....do. & .....do. & $92-96$ & 600 & 24 & 420 & 5.8 & 27 & 860 & 56 \\
\hline
\end{tabular}


Table 4. Distribution of element concentrations measured in sediment core samples, Mystic River Basin, Massachusetts.—Continued

[Station number: USGS sample identifiers and geographical coordinates are given in table 1; sampling locations shown on figure 3. D, duplicate; do., ditto; No., number; cm, centimeters; ppm, parts per million; \%, percent; <, actual value shown is less than the minimum reporting limit; --, not analyzed]

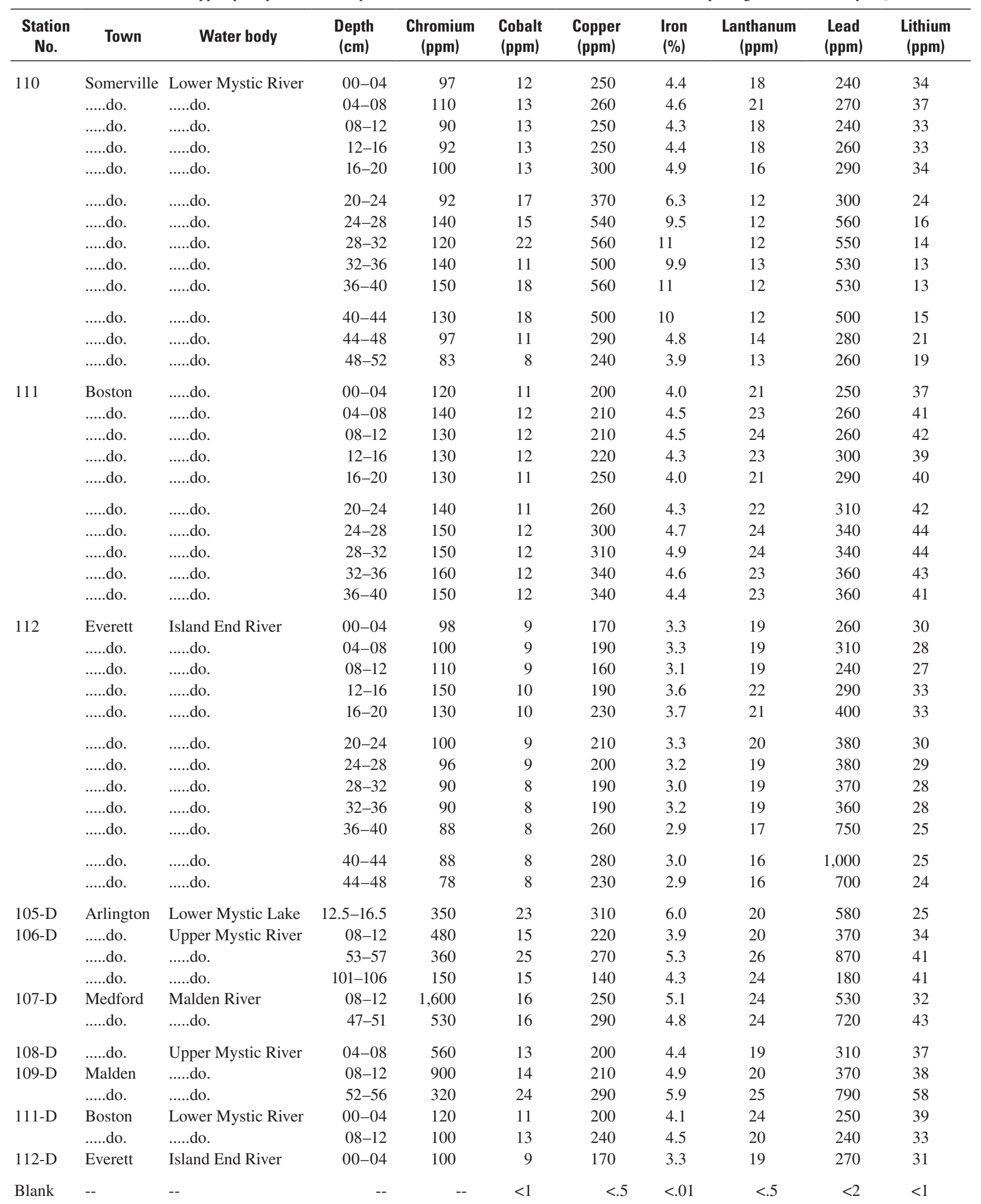


Table 4. Distribution of element concentrations measured in sediment core samples, Mystic River Basin, Massachusetts.-Continued

[Station number: USGS sample identifiers and geographical coordinates are given in table 1; sampling locations shown on figure 3. D, duplicate; do., ditto; No., number; cm, centimeters; ppm, parts per million; \%, percent; <, actual value shown is less than the minimum reporting limit; --, not analyzed]

\begin{tabular}{|c|c|c|c|c|c|c|c|c|c|c|}
\hline $\begin{array}{c}\text { Station } \\
\text { No. }\end{array}$ & Town & Water body & $\begin{array}{c}\text { Depth } \\
(\mathrm{cm})\end{array}$ & $\begin{array}{c}\text { Manganese } \\
\text { (ppm) }\end{array}$ & $\begin{array}{l}\text { Molybdenum } \\
\text { (ppm) }\end{array}$ & $\begin{array}{c}\text { Mercury } \\
\text { (ppm) }\end{array}$ & $\begin{array}{c}\text { Nickel } \\
\text { (ppm) }\end{array}$ & $\begin{array}{c}\text { Scandium } \\
\text { (ppm) }\end{array}$ & $\begin{array}{l}\text { Silver } \\
\text { (ppm) }\end{array}$ & $\begin{array}{l}\text { Strontium } \\
\text { (ppm) }\end{array}$ \\
\hline \multirow[t]{19}{*}{105} & Arlington & Lower Mystic Lake & $00-04$ & -- & -- & -- & -- & -- & -- & -- \\
\hline & .....do. & .....do. & $8.5-12.5$ & 820 & 5 & -- & 47 & 3.0 & .8 & 110 \\
\hline & .....do. & .....do. & $12.5-16.5$ & 730 & 6 & -- & 46 & 3.2 & 1.1 & 110 \\
\hline & .....do. & .....do. & $16.5-20.5$ & 630 & 4 & -- & 48 & 3.6 & 1.0 & 110 \\
\hline & .....do. & .....do. & $24.5-28.5$ & 410 & 4 & -- & 46 & 3.8 & 1.4 & 91 \\
\hline & .....do. & .....do. & $28.5-32.5$ & 400 & 5 & -- & 52 & 4.2 & 1.5 & 92 \\
\hline & .....do. & .....do. & $32.5-36.5$ & 360 & 5 & -- & 48 & 4.0 & 1.5 & 92 \\
\hline & .....do. & .....do. & $36.5-40.5$ & 370 & 5 & -- & 53 & 4.3 & 1.9 & 110 \\
\hline & .....do. & .....do. & $40.5-44.5$ & 370 & 15 & -- & 57 & 4.4 & 8.3 & 98 \\
\hline & .....do. & .....do. & $61-65$ & 420 & 17 & -- & 46 & 5.1 & 1.1 & 120 \\
\hline & .....do. & .....do. & $65-69$ & 400 & 9 & -- & 42 & 5.5 & .9 & 120 \\
\hline & .....do. & .....do. & $69-73$ & 350 & 5 & -- & 37 & 5.2 & .7 & 120 \\
\hline & .....do. & .....do. & $73-77.5$ & 210 & 7 & -- & 32 & 4.2 & .3 & 280 \\
\hline & .....do. & .....do. & $77.5-81$ & 380 & 5 & -- & 37 & 4.9 & .5 & 150 \\
\hline & .....do. & .....do. & $81-85$ & 340 & 7 & -- & 32 & 4.5 & .3 & 330 \\
\hline & .....do. & .....do. & $85-89$ & 490 & 12 & -- & 38 & 6.2 & .7 & 130 \\
\hline & .....do. & .....do. & 89-93 & 450 & 13 & -- & 39 & 6.2 & .4 & 89 \\
\hline & .....do. & .....do. & 93-97 & 390 & 17 & -- & 35 & 5.5 & 1.3 & 110 \\
\hline & .....do. & .....do. & 97-101 & 300 & 25 & -- & 30 & 4.9 & .7 & 87 \\
\hline \multirow{5}{*}{106} & .....do. & .....do. & $20-24$ & 470 & 6 & -- & 58 & 5.2 & 1.5 & 56 \\
\hline & .....do. & .....do. & 24-28 & 520 & 5 & -- & 52 & 6.6 & 1.2 & 69 \\
\hline & .....do. & .....do. & $28-32$ & 480 & 5 & -- & 42 & 6.4 & 1.0 & 62 \\
\hline & .....do. & .....do. & $32-36$ & 450 & 6 & -- & 41 & 6.0 & 1.2 & 90 \\
\hline & .....do. & .....do. & $36-39$ & 430 & 9 & -- & 50 & 5.2 & 1.2 & 73 \\
\hline \multirow[t]{10}{*}{107} & Medford & Malden River & 00-04 & 510 & 17 & -- & 110 & 4.5 & .9 & 65 \\
\hline & .....do. & .....do. & 04-08 & 500 & 19 & -- & 120 & 4.3 & 1.0 & 64 \\
\hline & .....do. & .....do. & $08-12$ & 490 & 16 & -- & 97 & 4.7 & .9 & 69 \\
\hline & .....do. & .....do. & $12-16$ & 520 & 10 & -- & 78 & 5.5 & .8 & 77 \\
\hline & .....do. & .....do. & $16-19.5$ & 530 & 9 & -- & 73 & 5.3 & .9 & 81 \\
\hline & .....do. & .....do. & $19.5-23$ & 550 & 11 & -- & 79 & 5.9 & 1.1 & 79 \\
\hline & .....do. & .....do. & $23-27$ & 530 & 9 & -- & 75 & 5.3 & 1.1 & 80 \\
\hline & .....do. & .....do. & $27-31$ & 530 & 10 & -- & 83 & 5.7 & 1.2 & 79 \\
\hline & .....do. & .....do. & $31-35$ & 450 & 9 & -- & 78 & 4.9 & 1.1 & 78 \\
\hline & .....do. & .....do. & $35-39$ & 460 & 11 & -- & 95 & 5.2 & 1.2 & 76 \\
\hline
\end{tabular}


Table 4. Distribution of element concentrations measured in sediment core samples, Mystic River Basin, Massachusetts.—Continued

[Station number: USGS sample identifiers and geographical coordinates are given in table 1; sampling locations shown on figure 3. D, duplicate; do., ditto; No., number; cm, centimeters; ppm, parts per million; \%, percent; <, actual value shown is less than the minimum reporting limit; --, not analyzed]

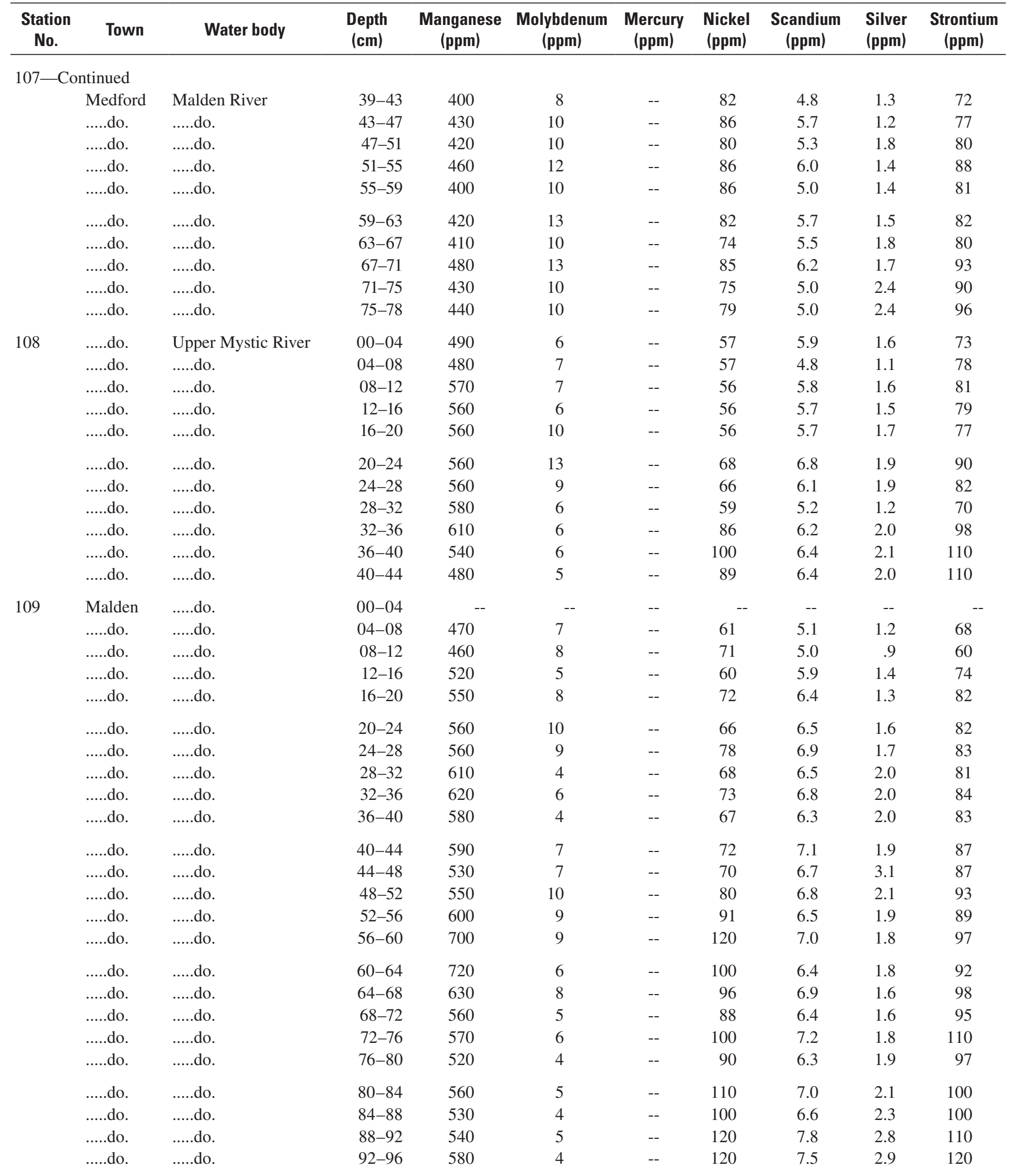


Table 4. Distribution of element concentrations measured in sediment core samples, Mystic River Basin, Massachusetts.—Continued

[Station number: USGS sample identifiers and geographical coordinates are given in table 1; sampling locations shown on figure 3. D, duplicate; do., ditto; No., number; cm, centimeters; ppm, parts per million; \%, percent; <, actual value shown is less than the minimum reporting limit; --, not analyzed]

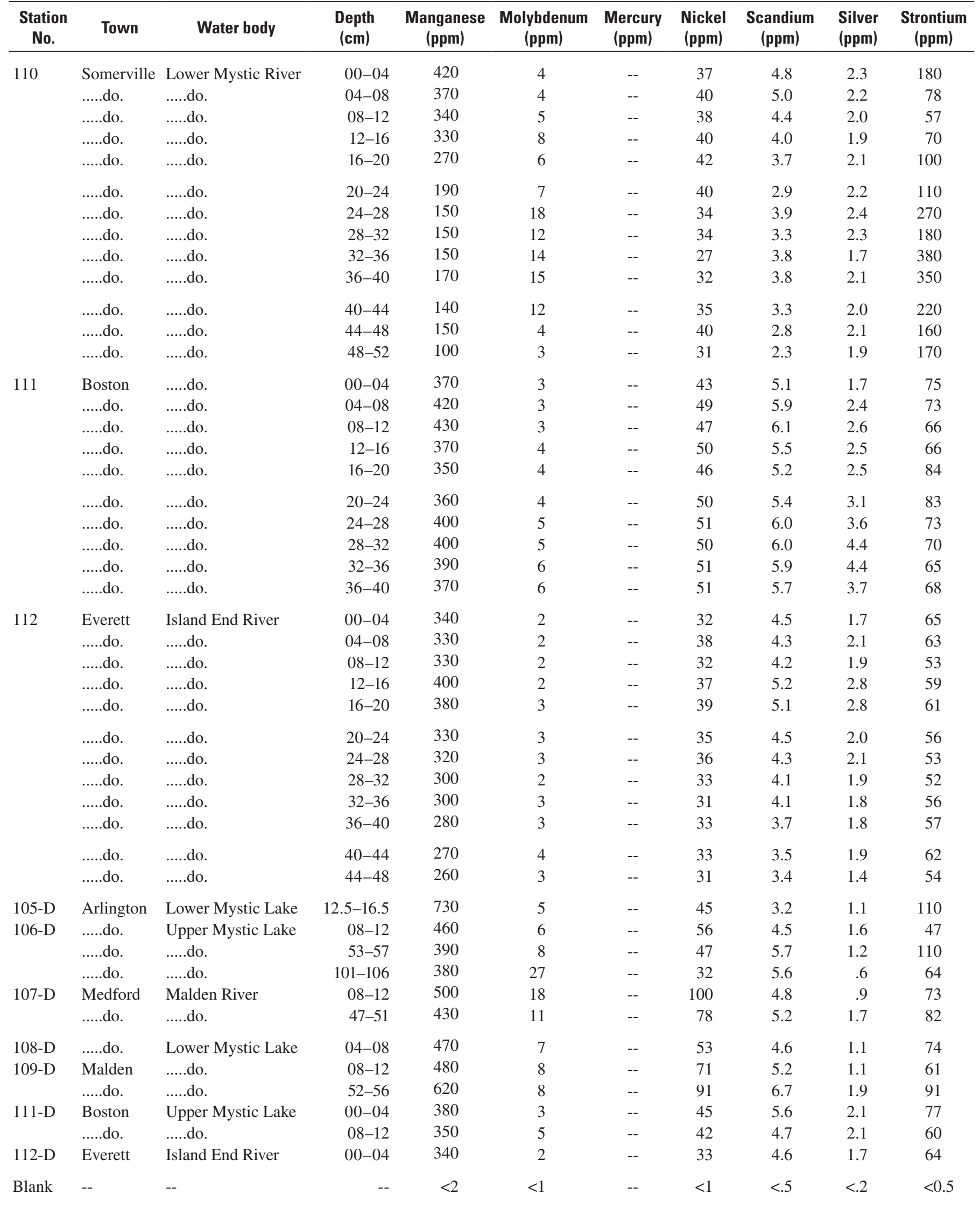


Table 4. Distribution of element concentrations measured in sediment core samples, Mystic River Basin, Massachusetts.—Continued

[Station number: USGS sample identifiers and geographical coordinates are given in table 1; sampling locations shown on figure 3. D, duplicate; do., ditto; No., number; cm, centimeters; ppm, parts per million; \%, percent; <, actual value shown is less than the minimum reporting limit; --, not analyzed]

\begin{tabular}{|c|c|c|c|c|c|c|c|c|c|c|}
\hline $\begin{array}{c}\text { Station } \\
\text { No. }\end{array}$ & Town & Water body & $\begin{array}{c}\text { Depth } \\
(\mathrm{cm})\end{array}$ & $\begin{array}{c}\text { Tin } \\
\text { (ppm) }\end{array}$ & $\begin{array}{c}\text { Titanium } \\
(\%)\end{array}$ & $\begin{array}{c}\text { Tungsten } \\
\text { (ppm) }\end{array}$ & $\begin{array}{c}\text { Vanadium } \\
\text { (ppm) }\end{array}$ & $\begin{array}{c}\text { Yttrium } \\
\text { (ppm) }\end{array}$ & $\begin{array}{l}\text { Zinc } \\
(\mathrm{ppm})\end{array}$ & $\begin{array}{c}\text { Zirconium } \\
\text { (ppm) }\end{array}$ \\
\hline \multirow[t]{18}{*}{105} & Arlington & Lower Mystic Lake & $00-04$ & -- & -- & -- & -- & -- & -- & -- \\
\hline & .....do. & .....do. & $8.5-12.5$ & $<10$ & .11 & $<10$ & 81 & 12 & 1,700 & 7.4 \\
\hline & .....do. & .....do. & $12.5-16.5$ & $<10$ & .11 & $<10$ & 83 & 13 & 1,800 & 8.4 \\
\hline & .....do. & .....do. & $16.5-20.5$ & $<10$ & .12 & $<10$ & 89 & 13 & 1,700 & 8.9 \\
\hline & .....do. & .....do. & $24.5-28.5$ & 11 & .13 & $<10$ & 88 & 13 & 1,900 & 8.9 \\
\hline & .....do. & .....do. & $28.5-32.5$ & 11 & .15 & $<10$ & 99 & 14 & 1,600 & 11 \\
\hline & .....do. & .....do. & $32.5-36.5$ & 12 & .14 & $<10$ & 98 & 14 & 1,900 & 10 \\
\hline & ......do. & .....do. & $36.5-40.5$ & 13 & .14 & $<10$ & 130 & 15 & 2,100 & 14 \\
\hline & .....do. & .....do. & $40.5-44.5$ & 21 & .14 & $<10$ & 150 & 14 & 1,700 & 9.6 \\
\hline & .....do. & .....do. & $61-65$ & 29 & .17 & $<10$ & 86 & 16 & 3,500 & 10 \\
\hline & .....do. & .....do. & $65-69$ & 15 & .20 & $<10$ & 77 & 19 & 3,700 & 9.5 \\
\hline & .....do. & .....do. & 69-73 & $<10$ & .21 & $<10$ & 73 & 20 & 3,500 & 8.0 \\
\hline & .....do. & .....do. & $73-77.5$ & 12 & .13 & $<10$ & 56 & 43 & 3,100 & 5.9 \\
\hline & .....do. & .....do. & $77.5-81$ & 20 & .18 & $<10$ & 69 & 34 & 6,900 & 6.6 \\
\hline & .....do. & .....do. & $81-85$ & 15 & .16 & $<10$ & 61 & 40 & 9,600 & 7.2 \\
\hline & .....do. & .....do. & $85-89$ & $<10$ & .19 & $<10$ & 66 & 22 & $>10,000$ & 9.2 \\
\hline & .....do. & .....do. & $89-93$ & $<10$ & .19 & $<10$ & 62 & 17 & 7,200 & 8.5 \\
\hline & .....do. & .....do. & $93-97$ & 14 & .16 & $<10$ & 64 & 17 & 6,000 & 9.3 \\
\hline \multirow{5}{*}{106} & .....do. & .....do. & $20-24$ & 19 & .13 & $<10$ & 82 & 15 & 980 & 14 \\
\hline & .....do. & .....do. & $24-28$ & 21 & .15 & $<10$ & 120 & 15 & 890 & 15 \\
\hline & .....do. & .....do. & $28-32$ & 14 & .15 & $<10$ & 97 & 14 & 530 & 15 \\
\hline & .....do. & .....do. & $32-36$ & 14 & .14 & $<10$ & 99 & 14 & 520 & 14 \\
\hline & .....do. & .....do. & $36-39$ & 22 & .13 & $<10$ & 91 & 13 & 1,100 & 15 \\
\hline \multirow[t]{10}{*}{107} & Medford & Malden River & $00-04$ & 51 & .11 & $<10$ & 77 & 15 & 1,300 & 16 \\
\hline & .....do. & .....do. & 04-08 & 55 & .11 & $<10$ & 76 & 14 & 1,200 & 16 \\
\hline & .....do. & .....do. & $08-12$ & 56 & .12 & $<10$ & 84 & 15 & 1,100 & 15 \\
\hline & .....do. & .....do. & $12-16$ & 76 & .12 & $<10$ & 93 & 16 & 1,100 & 15 \\
\hline & .....do. & .....do. & $16-19.5$ & 78 & .12 & $<10$ & 99 & 17 & 1,200 & 15 \\
\hline & .....do. & .....do. & $19.5-23$ & 81 & .13 & $<10$ & 98 & 16 & 1,100 & 16 \\
\hline & .....do. & .....do. & $23-27$ & 86 & .12 & $<10$ & 100 & 16 & 1,300 & 14 \\
\hline & .....do. & .....do. & $27-31$ & 87 & .12 & $<10$ & 96 & 16 & 1,200 & 15 \\
\hline & .....do. & .....do. & $31-35$ & 88 & .11 & $<10$ & 95 & 15 & 1,500 & 13 \\
\hline & .....do. & .....do. & $35-39$ & 88 & .12 & $<10$ & 94 & 15 & 1,500 & 16 \\
\hline
\end{tabular}


Table 4. Distribution of element concentrations measured in sediment core samples, Mystic River Basin, Massachusetts.-Continued

[Station number: USGS sample identifiers and geographical coordinates are given in table 1; sampling locations shown on figure 3. D, duplicate; do., ditto; No., number; cm, centimeters; ppm, parts per million; \%, percent; <, actual value shown is less than the minimum reporting limit; --, not analyzed]

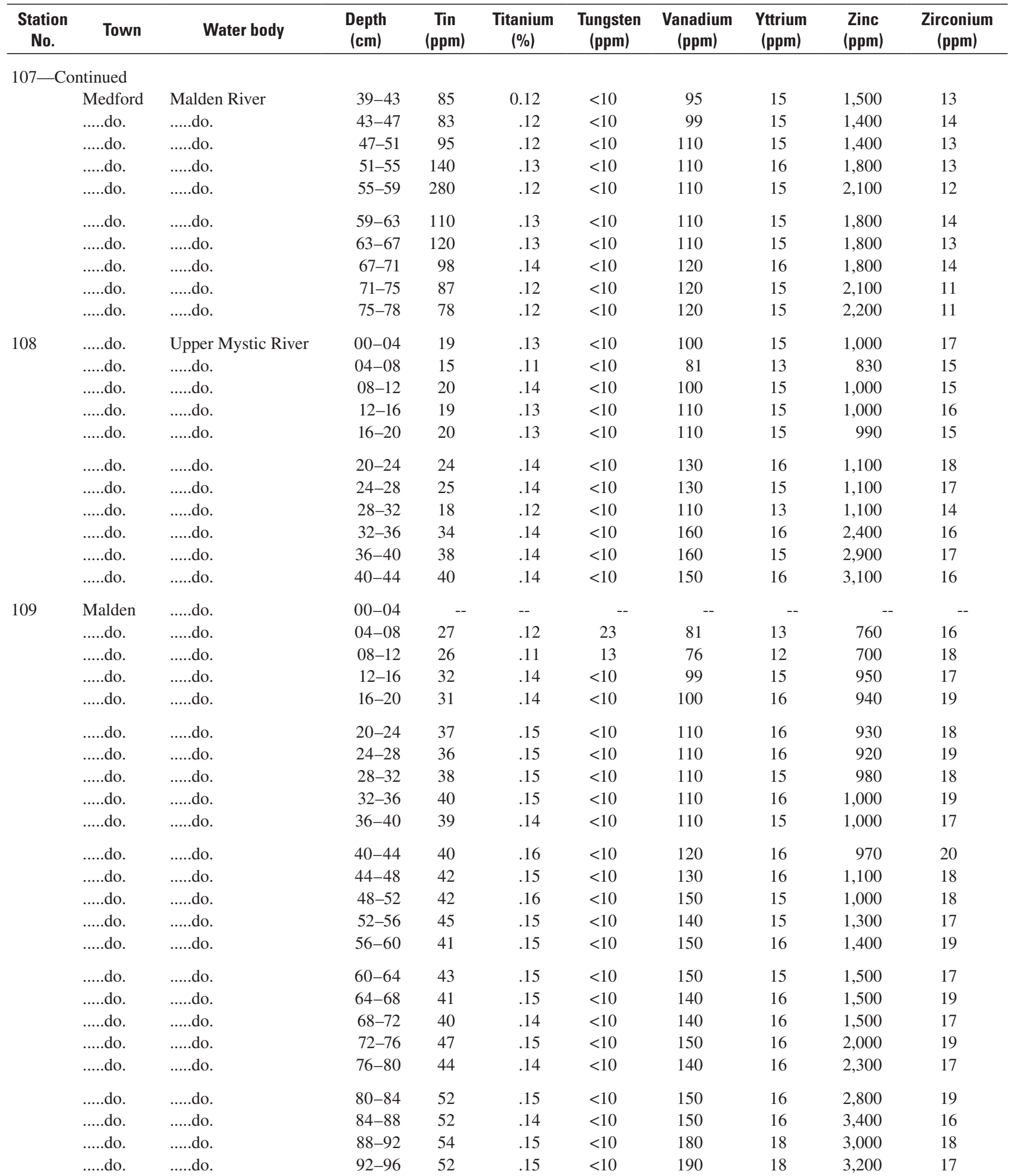


Table 4. Distribution of element concentrations measured in sediment core samples, Mystic River Basin, Massachusetts.—Continued

[Station number: USGS sample identifiers and geographical coordinates are given in table 1; sampling locations shown on figure 3. D, duplicate; do., ditto; No., number; cm, centimeters; ppm, parts per million; \%, percent; <, actual value shown is less than the minimum reporting limit; --, not analyzed]

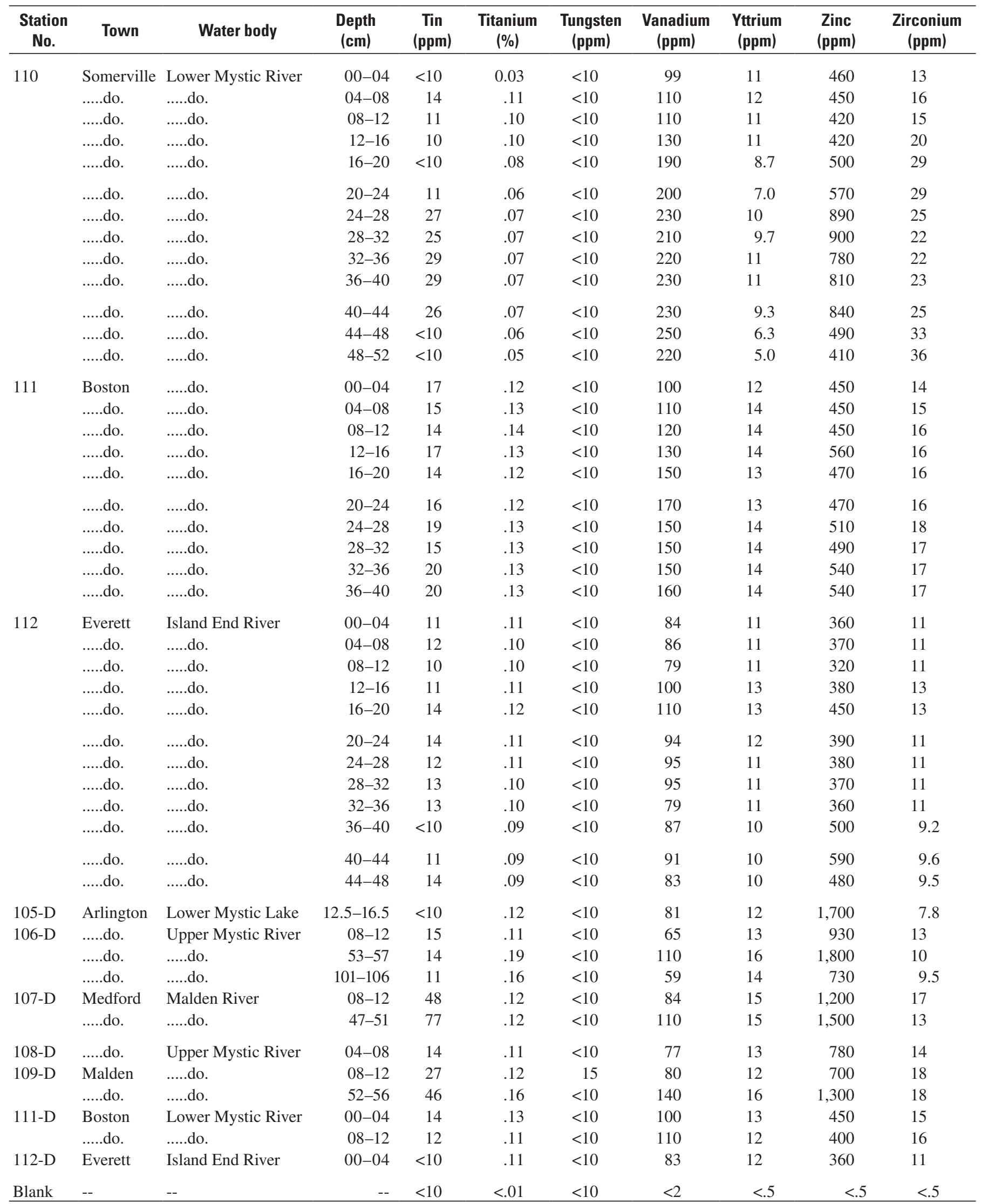


Table 5. Distribution of organic compound concentrations measured in sediment core samples, Mystic River Basin, Massachusetts.

[Station number: USGS sample identifiers and geographical coordinates are given in table 1; sampling locations shown on figure 3. BHC, 1,2,3,4,5,6-hexachlorocyclohexane; DDD, dichlorodiphenyldichloroethane; DDE, dichlorodiphenyldichloroethylene; DDT, dichlorodiphenyltrichloroethane; do., ditto; LD, lab duplicate; MDL, method detection limit; No., number; PCBs, polychlorinated biphenyls; cm, centimeters; ppm, parts per million; \%, percent; <, actual value shown is less than the minimum reporting limit; --, not analyzed]

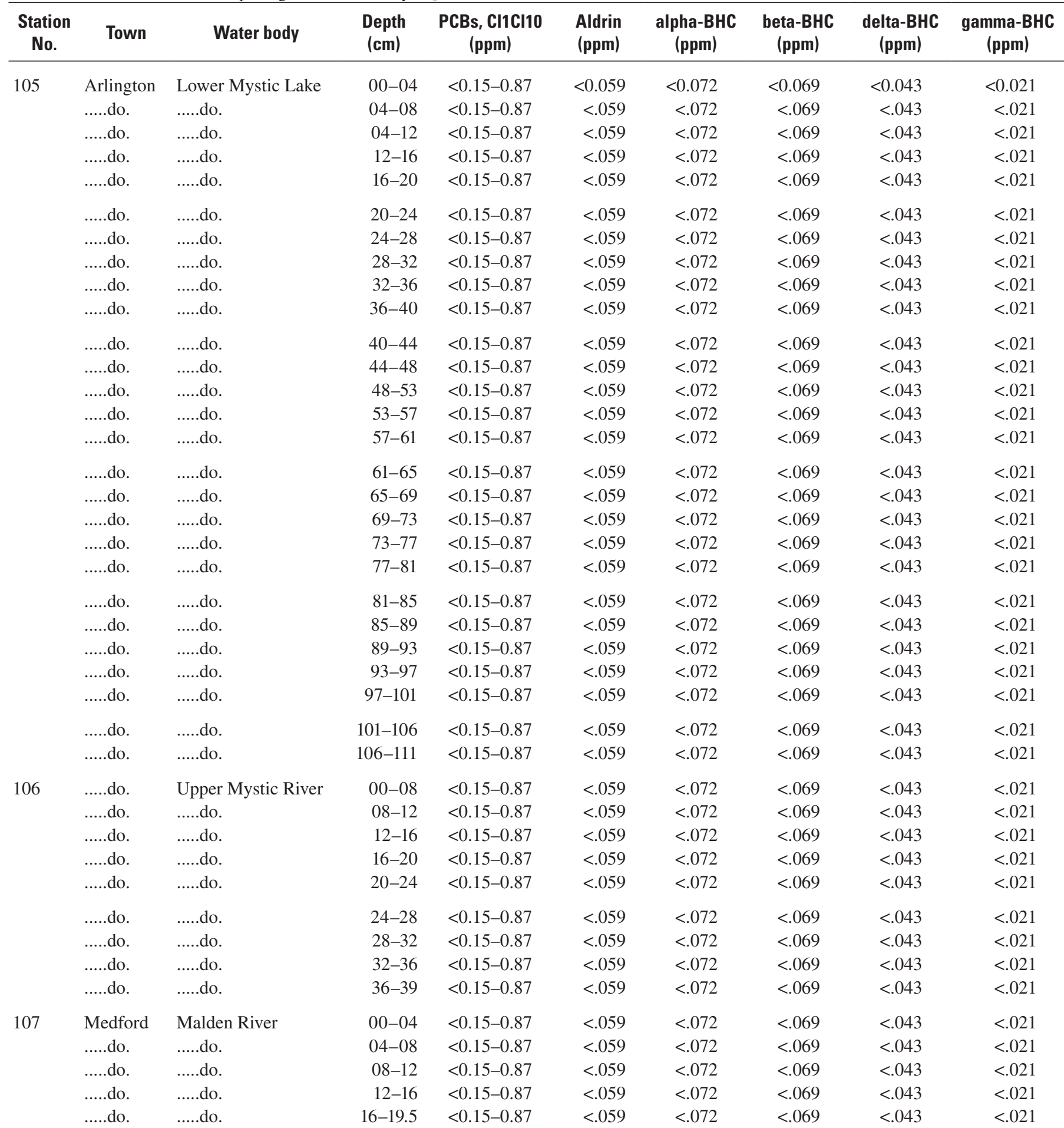


Table 5. Distribution of organic compound concentrations measured in sediment core samples, Mystic River Basin, Massachusetts.-Continued

[Station number: USGS sample identifiers and geographical coordinates are given in table 1; sampling locations shown on figure 3. BHC, 1,2,3,4,5,6-hexachlorocyclohexane; DDD, dichlorodiphenyldichloroethane; DDE, dichlorodiphenyldichloroethylene; DDT, dichlorodiphenyltrichloroethane; do., ditto; LD, lab duplicate; MDL, method detection limit; No., number; PCBs, polychlorinated biphenyls; cm, centimeters; ppm, parts per million; \%, percent; <, actual value shown is less than the minimum reporting limit; --, not analyzed]

\begin{tabular}{|c|c|c|c|c|c|c|c|c|c|}
\hline $\begin{array}{c}\text { Station } \\
\text { No. }\end{array}$ & Town & Water body & $\begin{array}{c}\text { Depth } \\
\text { (cm) }\end{array}$ & $\begin{array}{c}\text { PCBs, Cl1CI10 } \\
\text { (ppm) }\end{array}$ & $\begin{array}{l}\text { Aldrin } \\
\text { (ppm) }\end{array}$ & $\begin{array}{c}\text { alpha-BHC } \\
\text { (ppm) }\end{array}$ & $\begin{array}{c}\text { beta-BHC } \\
\text { (ppm) }\end{array}$ & $\begin{array}{c}\text { delta-BHC } \\
\text { (ppm) }\end{array}$ & $\begin{array}{c}\text { gamma-BHC } \\
\text { (ppm) }\end{array}$ \\
\hline \multicolumn{10}{|c|}{ 107-Continued } \\
\hline & Medford & Malden River & $19.5-23$ & $<0.15-0.87$ & $<0.059$ & $<0.072$ & $<0.069$ & $<0.043$ & $<0.021$ \\
\hline & .....do. & ....do. & $23-27$ & $<0.15-0.87$ & $<.059$ & $<.072$ & $<.069$ & $<.043$ & $<.021$ \\
\hline & .....do. & .....do. & $27-31$ & $<0.15-0.87$ & $<.059$ & $<.072$ & $<.069$ & $<.043$ & $<.021$ \\
\hline & .....do. & .....do. & $31-35$ & $<0.15-0.87$ & $<.059$ & $<.072$ & $<.069$ & $<.043$ & $<.021$ \\
\hline & .....do. & ....do. & $35-39$ & $<0.15-0.87$ & $<.059$ & $<.072$ & $<.069$ & $<.043$ & $<.021$ \\
\hline & ....do. & .....do. & $39-43$ & $<0.15-0.87$ & $<.059$ & $<.072$ & $<.069$ & $<.043$ & $<.021$ \\
\hline & .....do. & .....do. & $43-47$ & $<0.15-0.87$ & $<.059$ & $<.072$ & $<.069$ & $<.043$ & $<.021$ \\
\hline & .....do. & .....do. & $47-51$ & $<0.15-0.87$ & $<.059$ & $<.072$ & $<.069$ & $<.043$ & $<.021$ \\
\hline & .....do. & .....do. & $51-55$ & $<0.15-0.87$ & $<.059$ & $<.072$ & $<.069$ & $<.043$ & $<.021$ \\
\hline & .....do. & .....do. & $55-59$ & $<0.15-0.87$ & $<.059$ & $<.072$ & $<.069$ & $<.043$ & $<.021$ \\
\hline & ....do. & ....do. & $59-63$ & $<0.15-0.87$ & $<.059$ & $<.072$ & $<.069$ & $<.043$ & $<.021$ \\
\hline & .....do. & .....do. & $63-67$ & $<0.15-0.87$ & $<.059$ & $<.072$ & $<.069$ & $<.043$ & $<.021$ \\
\hline & ....do. & .....do. & $67-71$ & $<0.15-0.87$ & $<.059$ & $<.072$ & $<.069$ & $<.043$ & $<.021$ \\
\hline & .....do. & .....do. & $71-75$ & $<0.15-0.87$ & $<.059$ & $<.072$ & $<.069$ & $<.043$ & $<.021$ \\
\hline & ....do. & ....do. & $75-78$ & $<0.15-0.87$ & $<.059$ & $<.072$ & $<.069$ & $<.043$ & $<.021$ \\
\hline \multirow[t]{11}{*}{108} & .....do. & Upper Mystic River & $00-04$ & $<0.15-0.87$ & $<.059$ & $<.072$ & $<.069$ & $<.043$ & $<.021$ \\
\hline & .....do. & ....do. & 04-08 & $<0.15-0.87$ & $<.059$ & $<.072$ & $<.069$ & $<.043$ & $<.021$ \\
\hline & ....do. & ....do. & $08-12$ & $<0.15-0.87$ & $<.059$ & $<.072$ & $<.069$ & $<.043$ & $<.021$ \\
\hline & .....do. & ....do. & $12-16$ & $<0.15-0.87$ & $<.059$ & $<.072$ & $<.069$ & $<.043$ & $<.021$ \\
\hline & .....do. & ....do. & $16-20$ & $<0.15-0.87$ & $<.059$ & $<.072$ & $<.069$ & $<.043$ & $<.021$ \\
\hline & .....do. & ....do. & $20-24$ & $<0.15-0.87$ & $<.059$ & $<.072$ & $<.069$ & $<.043$ & $<.021$ \\
\hline & ....do. & ....do. & $24-28$ & $<0.15-0.87$ & $<.059$ & $<.072$ & $<.069$ & $<.043$ & $<.021$ \\
\hline & ....do. & ....do. & $28-32$ & $<0.15-0.87$ & $<.059$ & $<.072$ & $<.069$ & $<.043$ & $<.021$ \\
\hline & .....do. & .....do. & $32-36$ & $<0.15-0.87$ & $<.059$ & $<.072$ & $<.069$ & $<.043$ & $<.021$ \\
\hline & .....do. & .....do. & $36-40$ & $<0.15-0.87$ & $<.059$ & $<.072$ & $<.069$ & $<.043$ & $<.021$ \\
\hline & .....do. & .....do. & $40-44$ & $<0.15-0.87$ & $<.059$ & $<.072$ & $<.069$ & $<.043$ & $<.021$ \\
\hline \multirow[t]{15}{*}{109} & Malden & .....do. & 00-04 & $<0.15-0.87$ & $<.059$ & $<.072$ & $<.069$ & $<.043$ & $<.021$ \\
\hline & .....do. & .....do. & 04-08 & $<0.15-0.87$ & $<.059$ & $<.072$ & $<.069$ & $<.043$ & $<.021$ \\
\hline & ....do. & .....do. & $08-12$ & $<0.15-0.87$ & $<.059$ & $<.072$ & $<.069$ & $<.043$ & $<.021$ \\
\hline & ....do. & .....do. & $12-16$ & $<0.15-0.87$ & $<.059$ & $<.072$ & $<.069$ & $<.043$ & $<.021$ \\
\hline & .....do. & .....do. & $16-20$ & $<0.15-0.87$ & $<.059$ & $<.072$ & $<.069$ & $<.043$ & $<.021$ \\
\hline & .....do. & .....do. & $20-24$ & $<0.15-0.87$ & $<.059$ & $<.072$ & $<.069$ & $<.043$ & $<.021$ \\
\hline & ....do. & .....do. & $24-28$ & $<0.15-0.87$ & $<.059$ & $<.072$ & $<.069$ & $<.043$ & $<.021$ \\
\hline & ....do. & ....do. & $28-32$ & $<0.15-0.87$ & $<.059$ & $<.072$ & $<.069$ & $<.043$ & $<.021$ \\
\hline & .....do. & .....do. & $32-36$ & $<0.15-0.87$ & $<.059$ & $<.072$ & $<.069$ & $<.043$ & $<.021$ \\
\hline & .....do. & .....do. & $36-40$ & $<0.15-0.87$ & $<.059$ & $<.072$ & $<.069$ & $<.043$ & $<.021$ \\
\hline & .....do. & .....do. & $40-44$ & $<0.15-0.87$ & $<.059$ & $<.072$ & $<.069$ & $<.043$ & $<.021$ \\
\hline & .....do. & .....do. & $44-48$ & $<0.15-0.87$ & $<.059$ & $<.072$ & $<.069$ & $<.043$ & $<.021$ \\
\hline & .....do. & .....do. & $48-52$ & $<0.15-0.87$ & $<.059$ & $<.072$ & $<.069$ & $<.043$ & $<.021$ \\
\hline & .....do. & .....do. & $52-56$ & $<0.15-0.87$ & $<.059$ & $<.072$ & $<.069$ & $<.043$ & $<.021$ \\
\hline & .....do. & .....do. & $56-60$ & $<0.15-0.87$ & $<.059$ & $<.072$ & $<.069$ & $<.043$ & $<.021$ \\
\hline
\end{tabular}


Table 5. Distribution of organic compound concentrations measured in sediment core samples, Mystic River Basin, Massachusetts.-Continued

[Station number: USGS sample identifiers and geographical coordinates are given in table 1; sampling locations shown on figure 3. BHC, 1,2,3,4,5,6-hexachlorocyclohexane; DDD, dichlorodiphenyldichloroethane; DDE, dichlorodiphenyldichloroethylene; DDT, dichlorodiphenyltrichloroethane; do., ditto; LD, lab duplicate; MDL, method detection limit; No., number; PCBs, polychlorinated biphenyls; cm, centimeters; ppm, parts per million; \%, percent; <, actual value shown is less than the minimum reporting limit; --, not analyzed]

\begin{tabular}{|c|c|c|c|c|c|c|c|c|c|}
\hline $\begin{array}{c}\text { Station } \\
\text { No. }\end{array}$ & Town & Water body & $\begin{array}{l}\text { Depth } \\
\text { (cm) }\end{array}$ & $\begin{array}{c}\text { PCBs, Cl1CI10 } \\
\text { (ppm) }\end{array}$ & $\begin{array}{l}\text { Aldrin } \\
\text { (ppm) }\end{array}$ & $\begin{array}{c}\text { alpha-BHC } \\
\text { (ppm) }\end{array}$ & $\begin{array}{c}\text { beta-BHC } \\
\text { (ppm) }\end{array}$ & $\begin{array}{l}\text { delta-BHC } \\
\text { (ppm) }\end{array}$ & $\begin{array}{c}\text { gamma-BHC } \\
\text { (ppm) }\end{array}$ \\
\hline \multicolumn{10}{|c|}{ 109_Continued } \\
\hline & Malden & Upper Mystic River & $60-64$ & $<0.15-0.87$ & $<0.059$ & $<0.072$ & $<0.069$ & $<0.043$ & $<0.021$ \\
\hline & ....do. & ....do. & $64-68$ & $<0.15-0.87$ & $<.059$ & $<.072$ & $<.069$ & $<.043$ & $<.021$ \\
\hline & ....do. & .....do. & $68-72$ & $<0.15-0.87$ & $<.059$ & $<.072$ & $<.069$ & $<.043$ & $<.021$ \\
\hline & ....do. & ....do. & $72-76$ & $<0.15-0.87$ & $<.059$ & $<.072$ & $<.069$ & $<.043$ & $<.021$ \\
\hline & .....do. & ....do. & $76-80$ & $<0.15-0.87$ & $<.059$ & $<.072$ & $<.069$ & $<.043$ & $<.021$ \\
\hline & ....do. & ....do. & $80-84$ & $<0.15-0.87$ & $<.059$ & $<.072$ & $<.069$ & $<.043$ & $<.021$ \\
\hline & ....do. & .....do. & $84-88$ & $<0.15-0.87$ & $<.059$ & $<.072$ & $<.069$ & $<.043$ & $<.021$ \\
\hline & ....do. & ....do. & $88-92$ & $<0.15-0.87$ & $<.059$ & $<.072$ & $<.069$ & $<.043$ & $<.021$ \\
\hline & ....do. & ....do. & $92-96$ & $<0.15-0.87$ & $<.059$ & $<.072$ & $<.069$ & $<.043$ & $<.021$ \\
\hline \multirow[t]{12}{*}{110} & Somerville & Lower Mystic River & $00-04$ & $<0.15-0.87$ & $<.059$ & $<.072$ & $<.069$ & $<.043$ & $<.021$ \\
\hline & ....do. & ....do. & $04-08$ & $<0.15-0.87$ & $<.059$ & $<.072$ & $<.069$ & $<.043$ & $<.021$ \\
\hline & ....do. & ....do. & $08-12$ & $<0.15-0.87$ & $<.059$ & $<.072$ & $<.069$ & $<.043$ & $<.021$ \\
\hline & ....do. & .....do. & $12-16$ & $<0.15-0.87$ & $<.059$ & $<.072$ & $<.069$ & $<.043$ & $<.021$ \\
\hline & .....do. & .....do. & $16-20$ & $<0.15-0.87$ & $<.059$ & $<.072$ & $<.069$ & $<.043$ & $<.021$ \\
\hline & .....do. & .....do. & $20-24$ & $<0.15-0.87$ & $<.059$ & $<.072$ & $<.069$ & $<.043$ & $<.021$ \\
\hline & .....do. & .....do. & $24-28$ & $<0.15-0.87$ & $<.059$ & $<.072$ & $<.069$ & $<.043$ & $<.021$ \\
\hline & .....do. & .....do. & $28-32$ & $<0.15-0.87$ & $<.059$ & $<.072$ & $<.069$ & $<.043$ & $<.021$ \\
\hline & ....do. & .....do. & $32-36$ & $<0.15-0.87$ & $<.059$ & $<.072$ & $<.069$ & $<.043$ & $<.021$ \\
\hline & .....do. & .....do. & $36-40$ & $<0.15-0.87$ & $<.059$ & $<.072$ & $<.069$ & $<.043$ & $<.021$ \\
\hline & .....do. & .....do. & $40-44$ & $<0.15-0.87$ & $<.059$ & $<.072$ & $<.069$ & $<.043$ & $<.021$ \\
\hline & .....do. & .....do. & $44-48$ & $<0.15-0.87$ & $<.059$ & $<.072$ & $<.069$ & $<.043$ & $<.021$ \\
\hline \multirow[t]{6}{*}{111} & Boston & .....do. & 00-04 & $<0.15-0.87$ & $<.059$ & $<.072$ & $<.069$ & $<.043$ & $<.021$ \\
\hline & .....do. & .....do. & 04-08 & $<0.15-0.87$ & $<.059$ & $<.072$ & $<.069$ & $<.043$ & $<.021$ \\
\hline & .....do. & .....do. & $08-12$ & $<0.15-0.87$ & $<.059$ & $<.072$ & $<.069$ & $<.043$ & $<.021$ \\
\hline & .....do. & ....do. & $12-16$ & $<0.15-0.87$ & $<.059$ & $<.072$ & $<.069$ & $<.043$ & $<.021$ \\
\hline & ....do. & ....do. & $16-20$ & $<0.15-0.87$ & $<.059$ & $<.072$ & $<.069$ & $<.043$ & $<.021$ \\
\hline & .....do. & .....do. & $20-24$ & $<0.15-0.87$ & $<.059$ & $<.072$ & $<.069$ & $<.043$ & $<.021$ \\
\hline \multirow[t]{12}{*}{112} & Everett & Island End River & $00-04$ & $<0.15-0.87$ & $<.059$ & $<.072$ & $<.069$ & $<.043$ & $<.021$ \\
\hline & ....do. & ....do. & $04-08$ & $<0.15-0.87$ & $<.059$ & $<.072$ & $<.069$ & $<.043$ & $<.021$ \\
\hline & .....do. & .....do. & $08-12$ & $<0.15-0.87$ & $<.059$ & $<.072$ & $<.069$ & $<.043$ & $<.021$ \\
\hline & ....do. & ....do. & $12-16$ & $<0.15-0.87$ & $<.059$ & $<.072$ & $<.069$ & $<.043$ & $<.021$ \\
\hline & .....do. & .....do. & $16-20$ & $<0.15-0.87$ & $<.059$ & $<.072$ & $<.069$ & $<.043$ & $<.021$ \\
\hline & .....do. & .....do. & $20-24$ & $<0.15-0.87$ & $<.059$ & $<.072$ & $<.069$ & $<.043$ & $<.021$ \\
\hline & ....do. & .....do. & $24-28$ & $<0.15-0.87$ & $<.059$ & $<.072$ & $<.069$ & $<.043$ & $<.021$ \\
\hline & .....do. & .....do. & $28-32$ & $<0.15-0.87$ & $<.059$ & $<.072$ & $<.069$ & $<.043$ & $<.021$ \\
\hline & .....do. & .....do. & $32-36$ & $<0.15-0.87$ & $<.059$ & $<.072$ & $<.069$ & $<.043$ & $<.021$ \\
\hline & .....do. & .....do. & $36-40$ & $<0.15-0.87$ & $<.059$ & $<.072$ & $<.069$ & $<.043$ & $<.021$ \\
\hline & .....do. & .....do. & $40-44$ & $<0.15-0.87$ & $<.059$ & $<.072$ & $<.069$ & $<.043$ & $<.021$ \\
\hline & .....do. & ....do. & $44-48$ & $<0.15-0.87$ & $<.059$ & $<.072$ & $<.069$ & $<.043$ & $<.021$ \\
\hline
\end{tabular}


Table 5. Distribution of organic compound concentrations measured in sediment core samples, Mystic River Basin, Massachusetts.-Continued

[Station number: USGS sample identifiers and geographical coordinates are given in table 1; sampling locations shown on figure 3. BHC, 1,2,3,4,5,6-hexachlorocyclohexane; DDD, dichlorodiphenyldichloroethane; DDE, dichlorodiphenyldichloroethylene; DDT, dichlorodiphenyltrichloroethane; do., ditto; LD, lab duplicate; MDL, method detection limit; No., number; PCBs, polychlorinated biphenyls; cm, centimeters; ppm, parts per million; \%, percent; <, actual value shown is less than the minimum reporting limit; --, not analyzed]

\begin{tabular}{|c|c|c|c|c|c|c|c|c|c|}
\hline $\begin{array}{c}\text { Station } \\
\text { No. }\end{array}$ & Town & Water body & $\begin{array}{l}\text { Depth } \\
\text { (cm) }\end{array}$ & $\begin{array}{c}\text { PCBs, Cl1Cl10 } \\
\text { (ppm) }\end{array}$ & $\begin{array}{l}\text { Aldrin } \\
\text { (ppm) }\end{array}$ & $\begin{array}{c}\text { alpha-BHC } \\
\text { (ppm) }\end{array}$ & $\begin{array}{c}\text { beta-BHC } \\
\text { (ppm) }\end{array}$ & $\begin{array}{c}\text { delta-BHC } \\
\text { (ppm) }\end{array}$ & $\begin{array}{c}\text { gamma-BHC } \\
\text { (ppm) }\end{array}$ \\
\hline \multirow[t]{4}{*}{ 105-LD } & Arlington & Lower Mystic Lake & $24-28$ & $<0.15-0.87$ & $<0.059$ & $<0.072$ & $<0.069$ & $<0.043$ & $<0.021$ \\
\hline & .....do. & .....do. & $24-28$ & $<0.15-0.87$ & $<.059$ & $<.072$ & $<.069$ & $<.043$ & $<.021$ \\
\hline & ....do. & ....do. & $89-93$ & $<0.15-0.87$ & $<.059$ & $<.072$ & $<.069$ & $<.043$ & $<.021$ \\
\hline & ....do. & .....do. & $89-93$ & $<0.15-0.87$ & $<.059$ & $<.072$ & $<.069$ & $<.043$ & $<.021$ \\
\hline \multirow[t]{2}{*}{ 106-LD } & ....do. & Upper Mystic River & $16-20$ & $<0.15-0.87$ & $<.059$ & $<.072$ & $<.069$ & $<.043$ & $<.021$ \\
\hline & ....do. & ....do. & $16-20$ & $<0.15-0.87$ & $<.059$ & $<.072$ & $<.069$ & $<.043$ & $<.021$ \\
\hline \multirow[t]{4}{*}{ 107-LD } & Medford & Malden River & $19.5-23$ & $<0.15-0.87$ & $<.059$ & $<.072$ & $<.069$ & $<.043$ & $<.021$ \\
\hline & .....do. & ....do. & $19.5-23$ & $<0.15-0.87$ & $<.059$ & $<.072$ & $<.069$ & $<.043$ & $<.021$ \\
\hline & ....do. & ....do. & $67-71$ & $<0.15-0.87$ & $<.059$ & $<.072$ & $<.069$ & $<.043$ & $<.021$ \\
\hline & .....do. & .....do. & $67-71$ & $<0.15-0.87$ & $<.059$ & $<.072$ & $<.069$ & $<.043$ & $<.021$ \\
\hline \multirow[t]{2}{*}{ 108-LD } & .....do. & Upper Mystic River & $36-40$ & $<0.15-0.87$ & $<.059$ & $<.072$ & $<.069$ & $<.043$ & $<.021$ \\
\hline & .....do. & ....do. & $36-40$ & $<0.15-0.87$ & $<.059$ & $<.072$ & $<.069$ & $<.043$ & $<.021$ \\
\hline \multirow[t]{7}{*}{ 109-LD } & Malden & .....do. & $00-04$ & $<0.15-0.87$ & $<.059$ & $<.072$ & $<.069$ & $<.043$ & $<.021$ \\
\hline & .....do. & .....do. & $08-12$ & $<0.15-0.87$ & $<.059$ & $<.072$ & $<.069$ & $<.043$ & $<.021$ \\
\hline & .....do. & .....do. & 08-12 & $<0.15-0.87$ & $<.059$ & $<.072$ & $<.069$ & $<.043$ & $<.021$ \\
\hline & .....do. & .....do. & $56-60$ & $<0.15-0.87$ & $<.059$ & $<.072$ & $<.069$ & $<.043$ & $<.021$ \\
\hline & .....do. & .....do. & $56-60$ & $<0.15-0.87$ & $<.059$ & $<.072$ & $<.069$ & $<.043$ & $<.021$ \\
\hline & .....do. & .....do. & $84-88$ & $<0.15-0.87$ & $<.059$ & $<.072$ & $<.069$ & $<.043$ & $<.021$ \\
\hline & .....do. & .....do. & $84-88$ & $<0.15-0.87$ & $<.059$ & $<.072$ & $<.069$ & $<.043$ & $<.021$ \\
\hline \multirow[t]{6}{*}{ 111-LD } & Boston & Lower Mystic River & $00-04$ & $<0.15-0.87$ & $<.059$ & $<.072$ & $<.069$ & $<.043$ & $<.021$ \\
\hline & .....do. & ....do. & $04-08$ & $<0.15-0.87$ & $<.059$ & $<.072$ & $<.069$ & $<.043$ & $<.021$ \\
\hline & ....do. & ....do. & $08-12$ & $<0.15-0.87$ & $<.059$ & $<.072$ & $<.069$ & $<.043$ & $<.021$ \\
\hline & ....do. & ....do. & $12-16$ & $<0.15-0.87$ & $<.059$ & $<.072$ & $<.069$ & $<.043$ & $<.021$ \\
\hline & ....do. & ....do. & $16-20$ & $<0.15-0.87$ & $<.059$ & $<.072$ & $<.069$ & $<.043$ & $<.021$ \\
\hline & .....do. & .....do. & $20-24$ & $<0.15-0.87$ & $<.059$ & $<.072$ & $<.069$ & $<.043$ & $<.021$ \\
\hline \multirow[t]{12}{*}{ 112-LD } & Everett & Island End River & $00-04$ & $<0.15-0.87$ & $<.059$ & $<.072$ & $<.069$ & $<.043$ & $<.021$ \\
\hline & .....do. & ....do. & $04-08$ & $<0.15-0.87$ & $<.059$ & $<.072$ & $<.069$ & $<.043$ & $<.021$ \\
\hline & ....do. & ....do. & $08-12$ & $<0.15-0.87$ & $<.059$ & $<.072$ & $<.069$ & $<.043$ & $<.021$ \\
\hline & ....do. & ....do. & $12-16$ & $<0.15-0.87$ & $<.059$ & $<.072$ & $<.069$ & $<.043$ & $<.021$ \\
\hline & ....do. & .....do. & $16-20$ & $<0.15-0.87$ & $<.059$ & $<.072$ & $<.069$ & $<.043$ & $<.021$ \\
\hline & .....do. & .....do. & $20-24$ & $<0.15-0.87$ & $<.059$ & $<.072$ & $<.069$ & $<.043$ & $<.021$ \\
\hline & ....do. & ....do. & $24-28$ & $<0.15-0.87$ & $<.059$ & $<.072$ & $<.069$ & $<.043$ & $<.021$ \\
\hline & ....do. & ....do. & $28-32$ & $<0.15-0.87$ & $<.059$ & $<.072$ & $<.069$ & $<.043$ & $<.021$ \\
\hline & ....do. & .....do. & $32-36$ & $<0.15-0.87$ & $<.059$ & $<.072$ & $<.069$ & $<.043$ & $<.021$ \\
\hline & .....do. & .....do. & $36-40$ & $<0.15-0.87$ & $<.059$ & $<.072$ & $<.069$ & $<.043$ & $<.021$ \\
\hline & .....do. & .....do. & $40-44$ & $<0.15-0.87$ & $<.059$ & $<.072$ & $<.069$ & $<.043$ & $<.021$ \\
\hline & .....do. & .....do. & $44-48$ & $<0.15-0.87$ & $<.059$ & $<.072$ & $<.069$ & $<.043$ & $<.021$ \\
\hline
\end{tabular}


Table 5. Distribution of organic compound concentrations measured in sediment core samples, Mystic River Basin, Massachusetts.-Continued

[Station number: USGS sample identifiers and geographical coordinates are given in table 1; sampling locations shown on figure 3. BHC, 1,2,3,4,5,6-hexachlorocyclohexane; DDD, dichlorodiphenyldichloroethane; DDE, dichlorodiphenyldichloroethylene; DDT, dichlorodiphenyltrichloroethane; do., ditto; LD, lab duplicate; MDL, method detection limit; No., number; PCBs, polychlorinated biphenyls; cm, centimeters; ppm, parts per million; \%, percent; <, actual value shown is less than the minimum reporting limit; --, not analyzed]

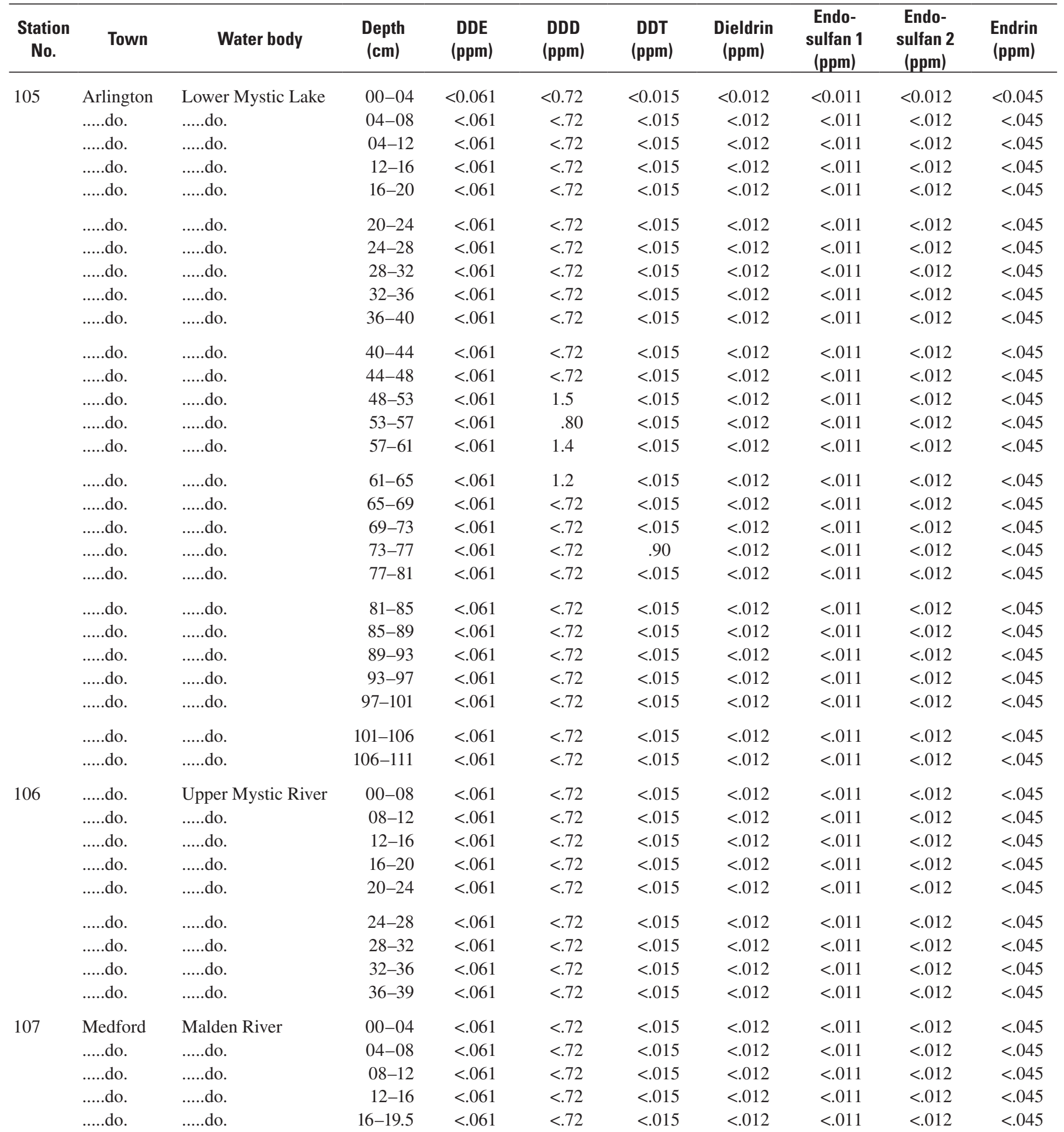


Table 5. Distribution of organic compound concentrations measured in sediment core samples, Mystic River Basin, Massachusetts.-Continued

[Station number: USGS sample identifiers and geographical coordinates are given in table 1; sampling locations shown on figure 3. BHC, 1,2,3,4,5,6-hexachlorocyclohexane; DDD, dichlorodiphenyldichloroethane; DDE, dichlorodiphenyldichloroethylene; DDT, dichlorodiphenyltrichloroethane; do., ditto; LD, lab duplicate; MDL, method detection limit; No., number; PCBs, polychlorinated biphenyls; cm, centimeters; ppm, parts per million; \%, percent; <, actual value shown is less than the minimum reporting limit; --, not analyzed]

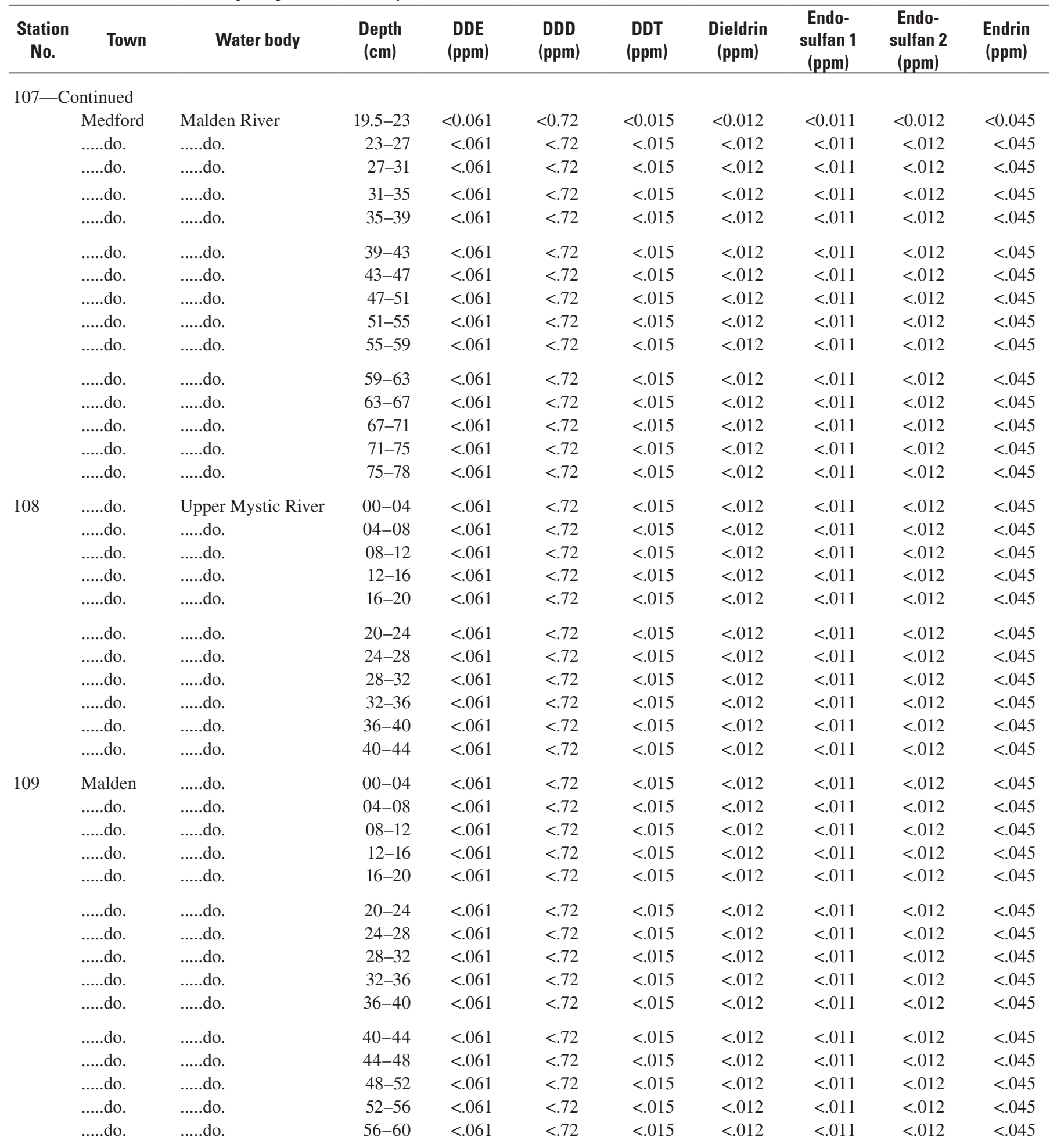


Table 5. Distribution of organic compound concentrations measured in sediment core samples, Mystic River Basin, Massachusetts.-Continued

[Station number: USGS sample identifiers and geographical coordinates are given in table 1; sampling locations shown on figure 3. BHC, 1,2,3,4,5,6-hexachlorocyclohexane; DDD, dichlorodiphenyldichloroethane; DDE, dichlorodiphenyldichloroethylene; DDT, dichlorodiphenyltrichloroethane; do., ditto; LD, lab duplicate; MDL, method detection limit; No., number; PCBs, polychlorinated biphenyls; cm, centimeters; ppm, parts per million; \%, percent; <, actual value shown is less than the minimum reporting limit; --, not analyzed]

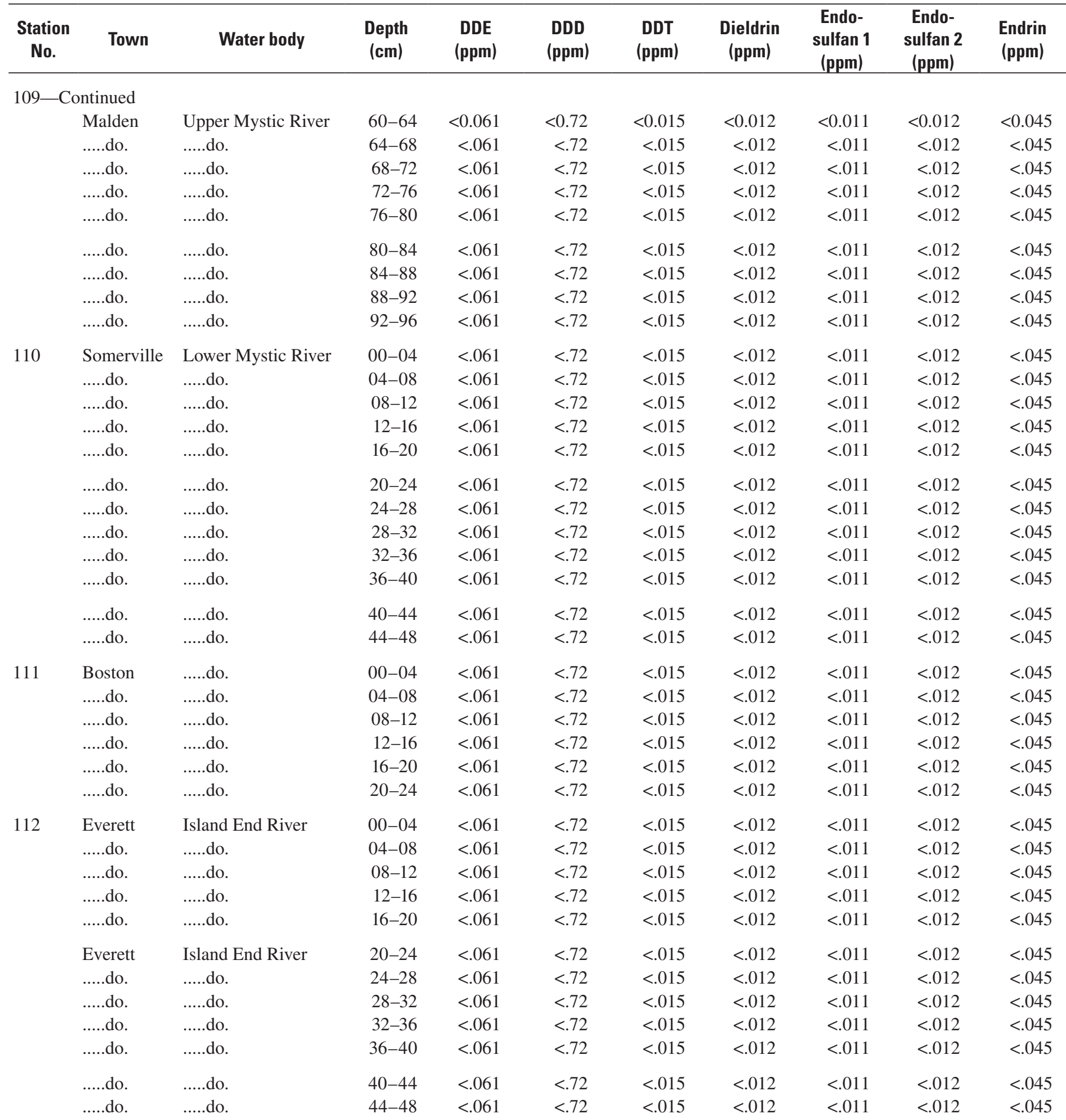


Table 5. Distribution of organic compound concentrations measured in sediment core samples, Mystic River Basin, Massachusetts.-Continued

[Station number: USGS sample identifiers and geographical coordinates are given in table 1; sampling locations shown on figure 3. BHC, 1,2,3,4,5,6-hexachlorocyclohexane; DDD, dichlorodiphenyldichloroethane; DDE, dichlorodiphenyldichloroethylene; DDT, dichlorodiphenyltrichloroethane; do., ditto; LD, lab duplicate; MDL, method detection limit; No., number; PCBs, polychlorinated biphenyls; cm, centimeters; ppm, parts per million; \%, percent; <, actual value shown is less than the minimum reporting limit; --, not analyzed]

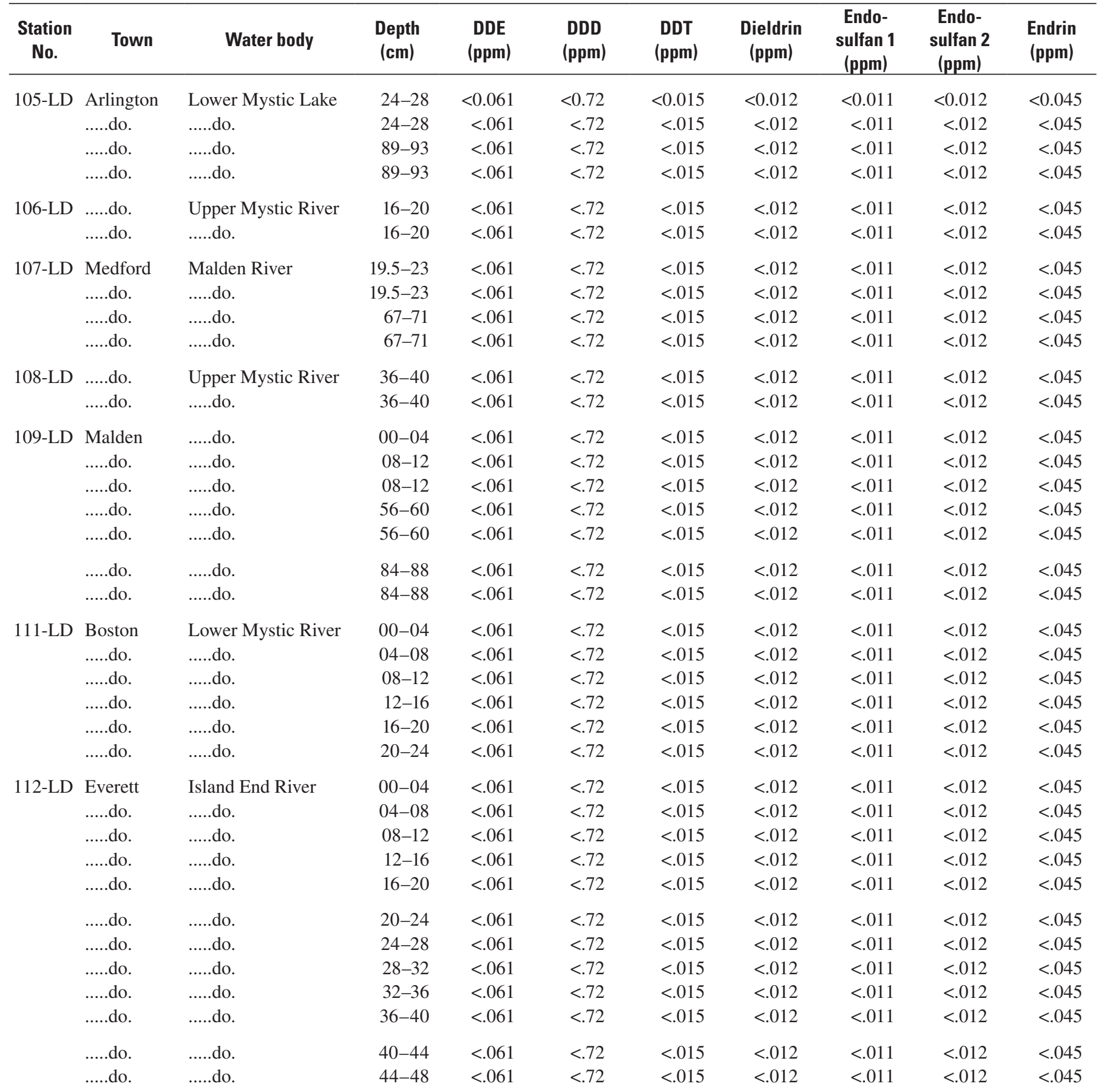


Table 5. Distribution of organic compound concentrations measured in sediment core samples, Mystic River Basin, Massachusetts.-Continued

[Station number: USGS sample identifiers and geographical coordinates are given in table 1; sampling locations shown on figure 3. BHC, 1,2,3,4,5,6-hexachlorocyclohexane; DDD, dichlorodiphenyldichloroethane; DDE, dichlorodiphenyldichloroethylene; DDT, dichlorodiphenyltrichloroethane; do., ditto; LD, lab duplicate; MDL, method detection limit; No., number; PCBs, polychlorinated biphenyls; cm, centimeters; ppm, parts per million; \%, percent; <, actual value shown is less than the minimum reporting limit; --, not analyzed]

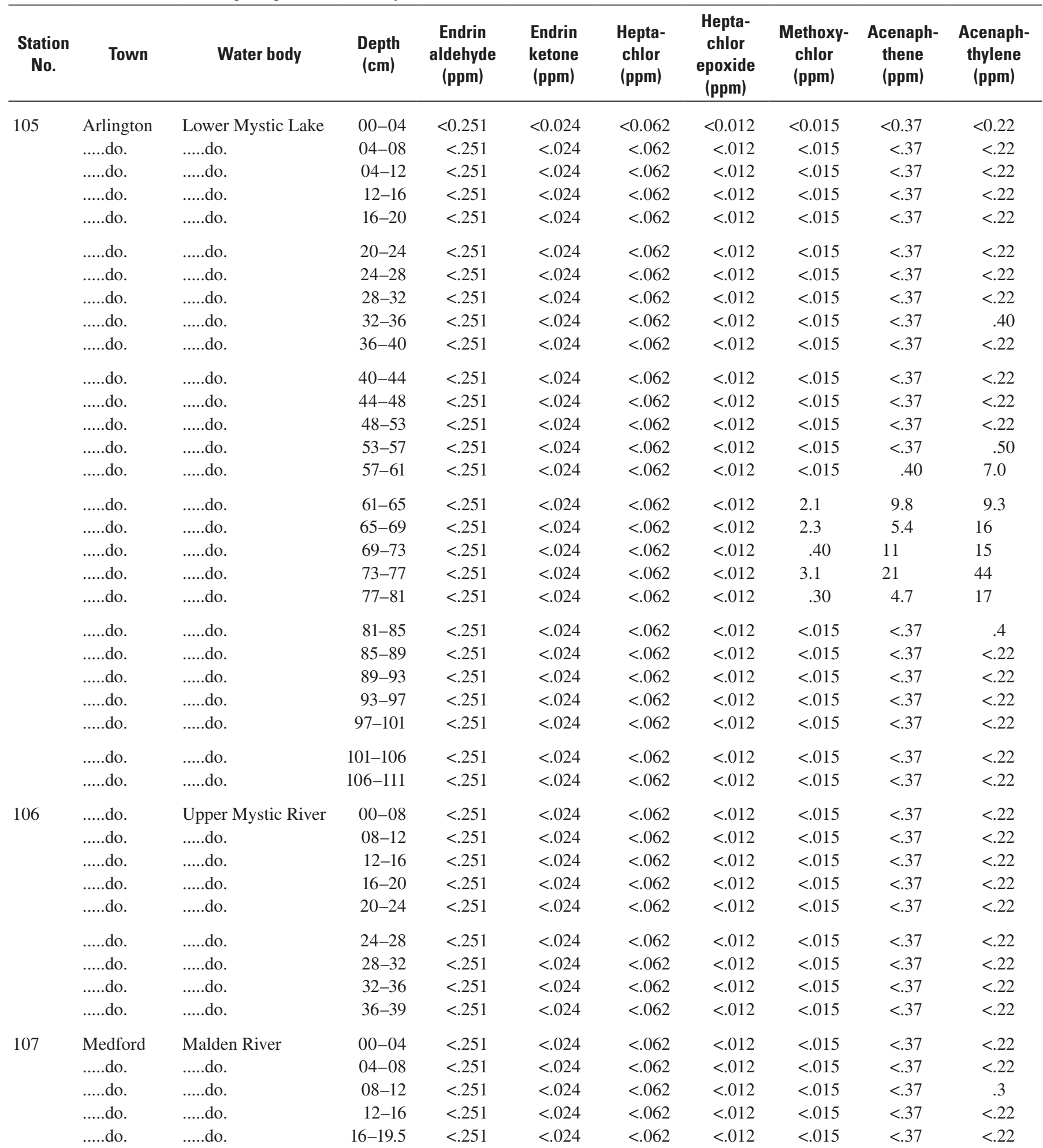


Table 5. Distribution of organic compound concentrations measured in sediment core samples, Mystic River Basin, Massachusetts.-Continued

[Station number: USGS sample identifiers and geographical coordinates are given in table 1; sampling locations shown on figure 3. BHC, 1,2,3,4,5,6-hexachlorocyclohexane; DDD, dichlorodiphenyldichloroethane; DDE, dichlorodiphenyldichloroethylene; DDT, dichlorodiphenyltrichloroethane; do., ditto; LD, lab duplicate; MDL, method detection limit; No., number; PCBs, polychlorinated biphenyls; cm, centimeters; ppm, parts per million; \%, percent; <, actual value shown is less than the minimum reporting limit; --, not analyzed]

\begin{tabular}{|c|c|c|c|c|c|c|c|c|c|c|}
\hline $\begin{array}{c}\text { Station } \\
\text { No. }\end{array}$ & Town & Water body & $\begin{array}{c}\text { Depth } \\
\text { (cm) }\end{array}$ & $\begin{array}{l}\text { Endrin } \\
\text { aldehyde } \\
\text { (ppm) }\end{array}$ & $\begin{array}{c}\text { Endrin } \\
\text { ketone } \\
\text { (ppm) }\end{array}$ & $\begin{array}{l}\text { Hepta- } \\
\text { chlor } \\
\text { (ppm) }\end{array}$ & $\begin{array}{c}\text { Hepta- } \\
\text { chlor } \\
\text { epoxide } \\
\text { (ppm) }\end{array}$ & $\begin{array}{c}\text { Methoxy- } \\
\text { chlor } \\
\text { (ppm) }\end{array}$ & $\begin{array}{c}\text { Acenaph- } \\
\text { thene } \\
\text { (ppm) }\end{array}$ & $\begin{array}{c}\text { Acenaph- } \\
\text { thylene } \\
\text { (ppm) }\end{array}$ \\
\hline \multicolumn{11}{|c|}{ 107-Continued } \\
\hline & Medford & Malden River & $19.5-23$ & $<0.251$ & $<0.024$ & $<0.062$ & $<0.012$ & $<0.015$ & $<0.37$ & 1.3 \\
\hline & ....do. & .....do. & $23-27$ & $<.251$ & $<.024$ & $<.062$ & $<.012$ & $<.015$ & $<.37$ & $<.22$ \\
\hline & .....do. & .....do. & $27-31$ & $<.251$ & $<.024$ & $<.062$ & $<.012$ & $<.015$ & 1.9 & .50 \\
\hline & .....do. & .....do. & $31-35$ & $<.251$ & $<.024$ & $<.062$ & $<.012$ & $<.015$ & 3.1 & $<.22$ \\
\hline & .....do. & ....do. & $35-39$ & $<.251$ & $<.024$ & $<.062$ & $<.012$ & $<.015$ & 1.2 & $<.22$ \\
\hline & ....do. & .....do. & $39-43$ & $<.251$ & $<.024$ & $<.062$ & $<.012$ & $<.015$ & $<.37$ & $<.22$ \\
\hline & .....do. & .....do. & $43-47$ & $<.251$ & $<.024$ & $<.062$ & $<.012$ & $<.015$ & $<.37$ & .3 \\
\hline & .....do. & .....do. & $47-51$ & $<.251$ & $<.024$ & $<.062$ & $<.012$ & $<.015$ & $<.37$ & $<.22$ \\
\hline & .....do. & .....do. & $51-55$ & $<.251$ & $<.024$ & $<.062$ & $<.012$ & $<.015$ & $<.37$ & $<.22$ \\
\hline & .....do. & .....do. & $55-59$ & $<.251$ & $<.024$ & $<.062$ & $<.012$ & $<.015$ & $<.37$ & $<.22$ \\
\hline & .....do. & .....do. & $59-63$ & $<.251$ & $<.024$ & $<.062$ & $<.012$ & $<.015$ & 2.3 & 1.5 \\
\hline & .....do. & .....do. & $63-67$ & $<.251$ & $<.024$ & $<.062$ & $<.012$ & $<.015$ & $<.37$ & .30 \\
\hline & .....do. & .....do. & $67-71$ & $<.251$ & $<.024$ & $<.062$ & $<.012$ & $<.015$ & .40 & 3.2 \\
\hline & .....do. & .....do. & $71-75$ & $<.251$ & $<.024$ & $<.062$ & $<.012$ & $<.015$ & $<.37$ & .20 \\
\hline & ....do. & .....do. & $75-78$ & $<.251$ & $<.024$ & $<.062$ & $<.012$ & .30 & 1.1 & 6.2 \\
\hline \multirow[t]{11}{*}{108} & .....do. & Upper Mystic River & $00-04$ & $<.251$ & $<.024$ & $<.062$ & $<.012$ & $<.015$ & $<.37$ & $<.22$ \\
\hline & ....do. & ....do. & 04-08 & $<.251$ & $<.024$ & $<.062$ & $<.012$ & $<.015$ & $<.37$ & $<.22$ \\
\hline & .....do. & .....do. & $08-12$ & $<.251$ & $<.024$ & $<.062$ & $<.012$ & $<.015$ & $<.37$ & $<.22$ \\
\hline & .....do. & .....do. & $12-16$ & $<.251$ & $<.024$ & $<.062$ & $<.012$ & $<.015$ & $<.37$ & $<.22$ \\
\hline & .....do. & .....do. & $16-20$ & $<.251$ & $<.024$ & $<.062$ & $<.012$ & $<.015$ & $<.37$ & $<.22$ \\
\hline & .....do. & .....do. & $20-24$ & $<.251$ & $<.024$ & $<.062$ & $<.012$ & $<.015$ & $<.37$ & $<.22$ \\
\hline & ....do. & ....do. & $24-28$ & $<.251$ & $<.024$ & $<.062$ & $<.012$ & $<.015$ & $<.37$ & $<.22$ \\
\hline & .....do. & .....do. & $28-32$ & $<.251$ & $<.024$ & $<.062$ & $<.012$ & $<.015$ & $<.37$ & $<.22$ \\
\hline & .....do. & .....do. & $32-36$ & $<.251$ & $<.024$ & $<.062$ & $<.012$ & $<.015$ & $<.37$ & $<.22$ \\
\hline & .....do. & .....do. & $36-40$ & $<.251$ & $<.024$ & $<.062$ & $<.012$ & $<.015$ & $<.37$ & $<.22$ \\
\hline & .....do. & .....do. & $40-44$ & $<.251$ & $<.024$ & $<.062$ & $<.012$ & $<.015$ & $<.37$ & $<.22$ \\
\hline \multirow[t]{15}{*}{109} & Malden & .....do. & $00-04$ & $<.251$ & $<.024$ & $<.062$ & $<.012$ & $<.015$ & $<.37$ & $<.22$ \\
\hline & .....do. & .....do. & 04-08 & $<.251$ & $<.024$ & $<.062$ & $<.012$ & $<.015$ & $<.37$ & $<.22$ \\
\hline & ....do. & .....do. & $08-12$ & $<.251$ & $<.024$ & $<.062$ & $<.012$ & $<.015$ & $<.37$ & $<.22$ \\
\hline & .....do. & .....do. & $12-16$ & $<.251$ & $<.024$ & $<.062$ & $<.012$ & $<.015$ & $<.37$ & $<.22$ \\
\hline & .....do. & .....do. & $16-20$ & $<.251$ & $<.024$ & $<.062$ & $<.012$ & $<.015$ & $<.37$ & $<.22$ \\
\hline & .....do. & .....do. & $20-24$ & $<.251$ & $<.024$ & $<.062$ & $<.012$ & $<.015$ & $<.37$ & $<.22$ \\
\hline & ....do. & .....do. & $24-28$ & $<.251$ & $<.024$ & $<.062$ & $<.012$ & $<.015$ & $<.37$ & $<.22$ \\
\hline & .....do. & .....do. & $28-32$ & $<.251$ & $<.024$ & $<.062$ & $<.012$ & $<.015$ & $<.37$ & $<.22$ \\
\hline & .....do. & ....do. & $32-36$ & $<.251$ & $<.024$ & $<.062$ & $<.012$ & $<.015$ & $<.37$ & $<.22$ \\
\hline & .....do. & .....do. & $36-40$ & $<.251$ & $<.024$ & $<.062$ & $<.012$ & $<.015$ & $<.37$ & $<.22$ \\
\hline & .....do. & .....do. & $40-44$ & $<.251$ & $<.024$ & $<.062$ & $<.012$ & $<.015$ & $<.37$ & $<.22$ \\
\hline & .....do. & .....do. & $44-48$ & $<.251$ & $<.024$ & $<.062$ & $<.012$ & $<.015$ & $<.37$ & $<.22$ \\
\hline & .....do. & .....do. & $48-52$ & $<.251$ & $<.024$ & $<.062$ & $<.012$ & $<.015$ & $<.37$ & $<.22$ \\
\hline & .....do. & .....do. & $52-56$ & $<.251$ & $<.024$ & $<.062$ & $<.012$ & $<.015$ & $<.37$ & $<.22$ \\
\hline & .....do. & .....do. & $56-60$ & $<.251$ & $<.024$ & $<.062$ & $<.012$ & $<.015$ & $<.37$ & $<.22$ \\
\hline
\end{tabular}


Table 5. Distribution of organic compound concentrations measured in sediment core samples, Mystic River Basin, Massachusetts.-Continued

[Station number: USGS sample identifiers and geographical coordinates are given in table 1; sampling locations shown on figure 3. BHC, 1,2,3,4,5,6-hexachlorocyclohexane; DDD, dichlorodiphenyldichloroethane; DDE, dichlorodiphenyldichloroethylene; DDT, dichlorodiphenyltrichloroethane; do., ditto; LD, lab duplicate; MDL, method detection limit; No., number; PCBs, polychlorinated biphenyls; cm, centimeters; ppm, parts per million; \%, percent; <, actual value shown is less than the minimum reporting limit; --, not analyzed]

\begin{tabular}{|c|c|c|c|c|c|c|c|c|c|c|}
\hline $\begin{array}{c}\text { Station } \\
\text { No. }\end{array}$ & Town & Water body & $\begin{array}{l}\text { Depth } \\
\text { (cm) }\end{array}$ & $\begin{array}{l}\text { Endrin } \\
\text { aldehyde } \\
\text { (ppm) }\end{array}$ & $\begin{array}{c}\text { Endrin } \\
\text { ketone } \\
(\mathrm{ppm})\end{array}$ & $\begin{array}{l}\text { Hepta- } \\
\text { chlor } \\
\text { (ppm) }\end{array}$ & $\begin{array}{l}\text { Hepta- } \\
\text { chlor } \\
\text { epoxide } \\
\text { (ppm) }\end{array}$ & $\begin{array}{c}\text { Methoxy- } \\
\text { chlor } \\
\text { (ppm) }\end{array}$ & $\begin{array}{c}\text { Acenaph- } \\
\text { thene } \\
\text { (ppm) }\end{array}$ & $\begin{array}{c}\text { Acenaph- } \\
\text { thylene } \\
\text { (ppm) }\end{array}$ \\
\hline \multicolumn{11}{|c|}{ 109-Continued } \\
\hline & Malden & Upper Mystic River & $60-64$ & $<0.251$ & $<0.024$ & $<0.062$ & $<0.012$ & $<0.015$ & $<0.37$ & $<0.22$ \\
\hline & .....do. & .....do. & $64-68$ & $<.251$ & $<.024$ & $<.062$ & $<.012$ & $<.015$ & $<.37$ & $<.22$ \\
\hline & .....do. & .....do. & $68-72$ & $<.251$ & $<.024$ & $<.062$ & $<.012$ & $<.015$ & $<.37$ & $<.22$ \\
\hline & .....do. & .....do. & $72-76$ & $<.251$ & $<.024$ & $<.062$ & $<.012$ & $<.015$ & $<.37$ & $<.22$ \\
\hline & .....do. & .....do. & $76-80$ & $<.251$ & $<.024$ & $<.062$ & $<.012$ & $<.015$ & $<.37$ & $<.22$ \\
\hline & .....do. & .....do. & $80-84$ & $<.251$ & $<.024$ & $<.062$ & $<.012$ & $<.015$ & $<.37$ & $<.22$ \\
\hline & .....do. & .....do. & $84-88$ & $<.251$ & $<.024$ & $<.062$ & $<.012$ & $<.015$ & $<.37$ & $<.22$ \\
\hline & .....do. & .....do. & $88-92$ & $<.251$ & $<.024$ & $<.062$ & $<.012$ & $<.015$ & $<.37$ & $<.22$ \\
\hline & .....do. & .....do. & $92-96$ & $<.251$ & $<.024$ & $<.062$ & $<.012$ & $<.015$ & $<.37$ & $<.22$ \\
\hline \multirow[t]{12}{*}{110} & Somerville & Lower Mystic River & $00-04$ & $<.251$ & $<.024$ & $<.062$ & $<.012$ & $<.015$ & $<.37$ & $<.22$ \\
\hline & .....do. & .....do. & 04-08 & $<.251$ & $<.024$ & $<.062$ & $<.012$ & $<.015$ & $<.37$ & $<.22$ \\
\hline & .....do. & .....do. & $08-12$ & $<.251$ & $<.024$ & $<.062$ & $<.012$ & $<.015$ & $<.37$ & $<.22$ \\
\hline & .....do. & .....do. & $12-16$ & $<.251$ & $<.024$ & $<.062$ & $<.012$ & $<.015$ & $<.37$ & $<.22$ \\
\hline & .....do. & .....do. & $16-20$ & $<.251$ & $<.024$ & $<.062$ & $<.012$ & $<.015$ & $<.37$ & $<.22$ \\
\hline & .....do. & .....do. & $20-24$ & $<.251$ & $<.024$ & $<.062$ & $<.012$ & $<.015$ & $<.37$ & $<.22$ \\
\hline & .....do. & .....do. & $24-28$ & $<.251$ & $<.024$ & $<.062$ & $<.012$ & $<.015$ & $<.37$ & $<.22$ \\
\hline & .....do. & .....do. & $28-32$ & $<.251$ & $<.024$ & $<.062$ & $<.012$ & $<.015$ & $<.37$ & $<.22$ \\
\hline & .....do. & .....do. & $32-36$ & $<.251$ & $<.024$ & $<.062$ & $<.012$ & $<.015$ & $<.37$ & $<.22$ \\
\hline & .....do. & .....do. & $36-40$ & $<.251$ & $<.024$ & $<.062$ & $<.012$ & $<.015$ & $<.37$ & $<.22$ \\
\hline & .....do. & .....do. & $40-44$ & $<.251$ & $<.024$ & $<.062$ & $<.012$ & $<.015$ & $<.37$ & $<.22$ \\
\hline & .....do. & .....do. & $44-48$ & $<.251$ & $<.024$ & $<.062$ & $<.012$ & $<.015$ & $<.37$ & $<.22$ \\
\hline \multirow[t]{6}{*}{111} & Boston & .....do. & 00-04 & $<.251$ & $<.024$ & $<.062$ & $<.012$ & $<.015$ & $<.37$ & $<.22$ \\
\hline & .....do. & .....do. & 04-08 & $<.251$ & $<.024$ & $<.062$ & $<.012$ & $<.015$ & $<.37$ & $<.22$ \\
\hline & .....do. & .....do. & $08-12$ & $<.251$ & $<.024$ & $<.062$ & $<.012$ & $<.015$ & $<.37$ & $<.22$ \\
\hline & .....do. & .....do. & $12-16$ & $<.251$ & $<.024$ & $<.062$ & $<.012$ & $<.015$ & $<.37$ & $<.22$ \\
\hline & .....do. & .....do. & $16-20$ & $<.251$ & $<.024$ & $<.062$ & $<.012$ & $<.015$ & $<.37$ & $<.22$ \\
\hline & .....do. & .....do. & $20-24$ & $<.251$ & $<.024$ & $<.062$ & $<.012$ & $<.015$ & $<.37$ & $<.22$ \\
\hline \multirow[t]{12}{*}{112} & Everett & Island End River & 00-04 & $<.251$ & $<.024$ & $<.062$ & $<.012$ & $<.015$ & $<.37$ & $<.22$ \\
\hline & ......do. & .....do. & 04-08 & $<.251$ & $<.024$ & $<.062$ & $<.012$ & $<.015$ & $<.37$ & $<.22$ \\
\hline & .....do. & .....do. & 08-12 & $<.251$ & $<.024$ & $<.062$ & $<.012$ & $<.015$ & $<.37$ & $<.22$ \\
\hline & .....do. & .....do. & $12-16$ & $<.251$ & $<.024$ & $<.062$ & $<.012$ & $<.015$ & $<.37$ & $<.22$ \\
\hline & .....do. & .....do. & $16-20$ & $<.251$ & $<.024$ & $<.062$ & $<.012$ & $<.015$ & $<.37$ & $<.22$ \\
\hline & .....do. & .....do. & $20-24$ & $<.251$ & $<.024$ & $<.062$ & $<.012$ & $<.015$ & $<.37$ & $<.22$ \\
\hline & .....do. & .....do. & 24-28 & $<.251$ & $<.024$ & $<.062$ & $<.012$ & $<.015$ & $<.37$ & $<.22$ \\
\hline & .....do. & .....do. & $28-32$ & $<.251$ & $<.024$ & $<.062$ & $<.012$ & $<.015$ & $<.37$ & $<.22$ \\
\hline & .....do. & .....do. & $32-36$ & $<.251$ & $<.024$ & $<.062$ & $<.012$ & $<.015$ & $<.37$ & $<.22$ \\
\hline & .....do. & .....do. & $36-40$ & $<.251$ & $<.024$ & $<.062$ & $<.012$ & $<.015$ & 21 & 7.8 \\
\hline & .....do. & .....do. & $40-44$ & $<.251$ & $<.024$ & $<.062$ & $<.012$ & $<.015$ & 58 & 10 \\
\hline & .....do. & .....do. & 44-48 & $<.251$ & $<.024$ & $<.062$ & $<.012$ & $<.015$ & 22 & 6.5 \\
\hline
\end{tabular}


Table 5. Distribution of organic compound concentrations measured in sediment core samples, Mystic River Basin, Massachusetts.-Continued

[Station number: USGS sample identifiers and geographical coordinates are given in table 1; sampling locations shown on figure 3. BHC, 1,2,3,4,5,6-hexachlorocyclohexane; DDD, dichlorodiphenyldichloroethane; DDE, dichlorodiphenyldichloroethylene; DDT, dichlorodiphenyltrichloroethane; do., ditto; LD, lab duplicate; MDL, method detection limit; No., number; PCBs, polychlorinated biphenyls; cm, centimeters; ppm, parts per million; \%, percent; <, actual value shown is less than the minimum reporting limit; --, not analyzed]

\begin{tabular}{|c|c|c|c|c|c|c|c|c|c|c|}
\hline $\begin{array}{c}\text { Station } \\
\text { No. }\end{array}$ & Town & Water body & $\begin{array}{l}\text { Depth } \\
\text { (cm) }\end{array}$ & $\begin{array}{l}\text { Endrin } \\
\text { aldehyde } \\
\text { (ppm) }\end{array}$ & $\begin{array}{l}\text { Endrin } \\
\text { ketone } \\
\text { (ppm) }\end{array}$ & $\begin{array}{l}\text { Hepta- } \\
\text { chlor } \\
\text { (ppm) }\end{array}$ & $\begin{array}{l}\text { Hepta- } \\
\text { chlor } \\
\text { epoxide } \\
\text { (ppm) }\end{array}$ & $\begin{array}{c}\text { Methoxy- } \\
\text { chlor } \\
\text { (ppm) }\end{array}$ & $\begin{array}{c}\text { Acenaph- } \\
\text { thene } \\
\text { (ppm) }\end{array}$ & $\begin{array}{c}\text { Acenaph- } \\
\text { thylene } \\
\text { (ppm) }\end{array}$ \\
\hline \multirow[t]{4}{*}{ 105-LD } & Arlington & Lower Mystic Lake & $24-28$ & $<0.251$ & $<0.024$ & $<0.062$ & $<0.012$ & $<0.015$ & $<0.37$ & $<0.22$ \\
\hline & ....do. & ....do. & $24-28$ & $<.251$ & $<.024$ & $<.062$ & $<.012$ & $<.015$ & $<.37$ & $<.22$ \\
\hline & .....do. & ....do. & $89-93$ & $<.251$ & $<.024$ & $<.062$ & $<.012$ & $<.015$ & $<.37$ & $<.22$ \\
\hline & .....do. & .....do. & $89-93$ & $<.251$ & $<.024$ & $<.062$ & $<.012$ & $<.015$ & $<.37$ & $<.22$ \\
\hline \multirow[t]{2}{*}{ 106-LD } & .....do. & Upper Mystic Lake & $16-20$ & $<.251$ & $<.024$ & $<.062$ & $<.012$ & $<.015$ & $<.37$ & $<.22$ \\
\hline & .....do. & ....do. & $16-20$ & $<.251$ & $<.024$ & $<.062$ & $<.012$ & $<.015$ & $<.37$ & $<.22$ \\
\hline \multirow[t]{4}{*}{ 107-LD } & Medford & Malden River & $19.5-23$ & $<.251$ & $<.024$ & $<.062$ & $<.012$ & .015 & $<.37$ & .30 \\
\hline & ....do. & ....do. & $19.5-23$ & $<.251$ & $<.024$ & $<.062$ & $<.012$ & $<.015$ & $<.37$ & $<.22$ \\
\hline & ....do. & ....do. & $67-71$ & $<.251$ & $<.024$ & $<.062$ & $<.012$ & $<.015$ & 1.0 & 2.3 \\
\hline & .....do. & .....do. & $67-71$ & $<.251$ & $<.024$ & $<.062$ & $<.012$ & $<.015$ & 1.0 & 2.0 \\
\hline \multirow[t]{2}{*}{ 108-LD } & .....do. & Upper Mystic Lake & $36-40$ & $<.251$ & $<.024$ & $<.062$ & $<.012$ & $<.015$ & $<.37$ & $<.22$ \\
\hline & .....do. & ....do. & $36-40$ & $<.251$ & $<.024$ & $<.062$ & $<.012$ & $<.015$ & $<.37$ & $<.22$ \\
\hline \multirow[t]{7}{*}{ 109-LD } & Malden & ....do. & $00-04$ & $<.251$ & $<.024$ & $<.062$ & $<.012$ & $<.015$ & $<.37$ & $<.22$ \\
\hline & ....do. & ....do. & $08-12$ & $<.251$ & $<.024$ & $<.062$ & $<.012$ & $<.015$ & $<.37$ & $<.22$ \\
\hline & ....do. & ....do. & $08-12$ & $<.251$ & $<.024$ & $<.062$ & $<.012$ & $<.015$ & $<.37$ & $<.22$ \\
\hline & ....do. & ....do. & $56-60$ & $<.251$ & $<.024$ & $<.062$ & $<.012$ & $<.015$ & $<.37$ & $<.22$ \\
\hline & .....do. & .....do. & $56-60$ & $<.251$ & $<.024$ & $<.062$ & $<.012$ & $<.015$ & $<.37$ & $<.22$ \\
\hline & .....do. & .....do. & $84-88$ & $<.251$ & $<.024$ & $<.062$ & $<.012$ & $<.015$ & $<.37$ & $<.22$ \\
\hline & .....do. & .....do. & $84-88$ & $<.251$ & $<.024$ & $<.062$ & $<.012$ & $<.015$ & $<.37$ & $<.22$ \\
\hline \multirow[t]{6}{*}{ 111-LD } & Boston & Lower Mystic Lake & $00-04$ & $<.251$ & $<.024$ & $<.062$ & $<.012$ & $<.015$ & $<.37$ & $<.22$ \\
\hline & .....do. & ....do. & $04-08$ & $<.251$ & $<.024$ & $<.062$ & $<.012$ & $<.015$ & $<.37$ & $<.22$ \\
\hline & ....do. & ....do. & $08-12$ & $<.251$ & $<.024$ & $<.062$ & $<.012$ & $<.015$ & $<.37$ & $<.22$ \\
\hline & .....do. & .....do. & $12-16$ & $<.251$ & $<.024$ & $<.062$ & $<.012$ & $<.015$ & $<.37$ & $<.22$ \\
\hline & .....do. & ....do. & $16-20$ & $<.251$ & $<.024$ & $<.062$ & $<.012$ & $<.015$ & $<.37$ & $<.22$ \\
\hline & .....do. & .....do. & $20-24$ & $<.251$ & $<.024$ & $<.062$ & $<.012$ & $<.015$ & $<.37$ & $<.22$ \\
\hline \multirow[t]{12}{*}{ 112-LD } & Everett & Island End River & $00-04$ & $<.251$ & $<.024$ & $<.062$ & $<.012$ & $<.015$ & $<.37$ & $<.22$ \\
\hline & ....do. & ....do. & $04-08$ & $<.251$ & $<.024$ & $<.062$ & $<.012$ & $<.015$ & $<.37$ & $<.22$ \\
\hline & ....do. & .....do. & $08-12$ & $<.251$ & $<.024$ & $<.062$ & $<.012$ & $<.015$ & $<.37$ & $<.22$ \\
\hline & ....do. & ....do. & $12-16$ & $<.251$ & $<.024$ & $<.062$ & $<.012$ & $<.015$ & $<.37$ & $<.22$ \\
\hline & .....do. & .....do. & $16-20$ & $<.251$ & $<.024$ & $<.062$ & $<.012$ & $<.015$ & $<.37$ & $<.22$ \\
\hline & ....do. & ....do. & $20-24$ & $<.251$ & $<.024$ & $<.062$ & $<.012$ & $<.015$ & $<.37$ & $<.22$ \\
\hline & .....do. & ....do. & $24-28$ & $<.251$ & $<.024$ & $<.062$ & $<.012$ & $<.015$ & $<.37$ & $<.22$ \\
\hline & .....do. & .....do. & $28-32$ & $<.251$ & $<.024$ & $<.062$ & $<.012$ & $<.015$ & $<.37$ & $<.22$ \\
\hline & .....do. & ....do. & $32-36$ & $<.251$ & $<.024$ & $<.062$ & $<.012$ & $<.015$ & $<.37$ & $<.22$ \\
\hline & .....do. & .....do. & $36-40$ & $<.251$ & $<.024$ & $<.062$ & $<.012$ & $<.015$ & 19 & 6.6 \\
\hline & .....do. & .....do. & $40-44$ & $<.251$ & $<.024$ & $<.062$ & $<.012$ & $<.015$ & 38 & 7.4 \\
\hline & .....do. & .....do. & $44-48$ & $<.251$ & $<.024$ & $<.062$ & $<.012$ & $<.015$ & 21 & 6.6 \\
\hline
\end{tabular}


Table 5. Distribution of organic compound concentrations measured in sediment core samples, Mystic River Basin, Massachusetts.-Continued

[Station number: USGS sample identifiers and geographical coordinates are given in table 1; sampling locations shown on figure 3. BHC, 1,2,3,4,5,6-hexachlorocyclohexane; DDD, dichlorodiphenyldichloroethane; DDE, dichlorodiphenyldichloroethylene; DDT, dichlorodiphenyltrichloroethane; do., ditto; LD, lab duplicate; MDL, method detection limit; No., number; PCBs, polychlorinated biphenyls; cm, centimeters; ppm, parts per million; \%, percent; <, actual value shown is less than the minimum reporting limit; --, not analyzed]

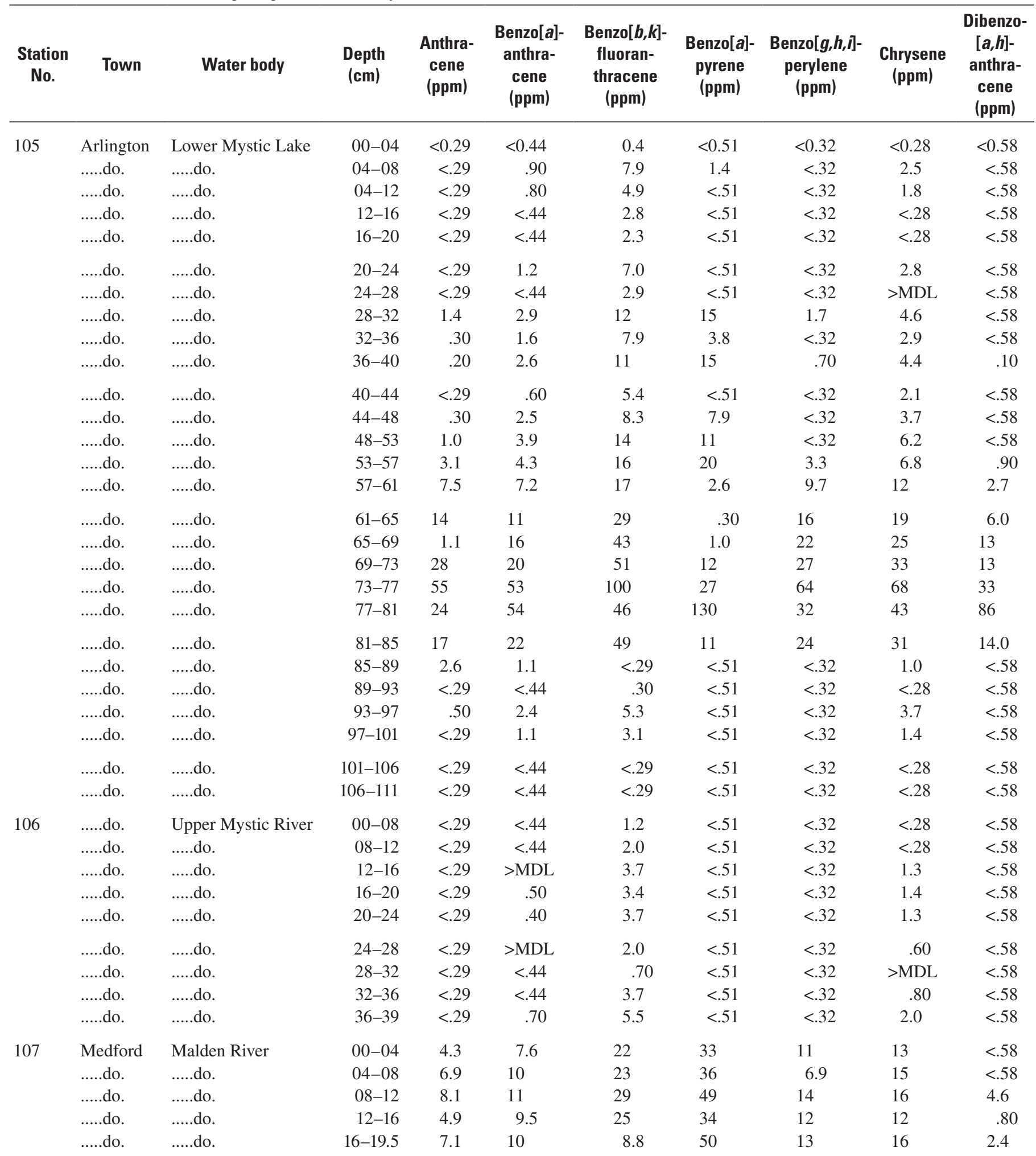


Table 5. Distribution of organic compound concentrations measured in sediment core samples, Mystic River Basin, Massachusetts.-Continued

[Station number: USGS sample identifiers and geographical coordinates are given in table 1; sampling locations shown on figure 3. BHC, 1,2,3,4,5,6-hexachlorocyclohexane; DDD, dichlorodiphenyldichloroethane; DDE, dichlorodiphenyldichloroethylene; DDT, dichlorodiphenyltrichloroethane; do., ditto; LD, lab duplicate; MDL, method detection limit; No., number; PCBs, polychlorinated biphenyls; cm, centimeters; ppm, parts per million; \%, percent; <, actual value shown is less than the minimum reporting limit; --, not analyzed]

\begin{tabular}{|c|c|c|c|c|c|c|c|c|c|c|}
\hline $\begin{array}{c}\text { Station } \\
\text { No. }\end{array}$ & Town & Water body & $\begin{array}{l}\text { Depth } \\
\text { (cm) }\end{array}$ & $\begin{array}{c}\text { Anthra- } \\
\text { cene } \\
\text { (ppm) }\end{array}$ & $\begin{array}{c}\text { Benzo[a]- } \\
\text { anthra- } \\
\text { cene } \\
\text { (ppm) }\end{array}$ & $\begin{array}{c}\text { Benzo }[b, k]- \\
\text { fluoran- } \\
\text { thracene } \\
\text { (ppm) }\end{array}$ & $\begin{array}{c}\text { Benzo[a]- } \\
\text { pyrene } \\
\text { (ppm) }\end{array}$ & $\begin{array}{c}\text { Benzo[g,h,i]- } \\
\text { perylene } \\
\text { (ppm) }\end{array}$ & $\begin{array}{c}\text { Chrysene } \\
\text { (ppm) }\end{array}$ & $\begin{array}{c}\text { Dibenzo } \\
{[a, h]-} \\
\text { anthra- } \\
\text { cene } \\
\text { (ppm) }\end{array}$ \\
\hline \multicolumn{11}{|c|}{ 107-Continued } \\
\hline & Medford & Malden River & $19.5-23$ & 5.4 & 8.8 & 25 & 47 & 15 & 14 & 1.8 \\
\hline & .....do. & .....do. & $23-27$ & 4.3 & 7.6 & 18 & 27 & 3.4 & 11 & $<.58$ \\
\hline & .....do. & .....do. & $27-31$ & 8.3 & 8.3 & 6.9 & 33 & 8.7 & 12 & 1.5 \\
\hline & .....do. & .....do. & $31-35$ & 7.9 & 9.0 & 19 & 28 & 2.8 & 12 & $<.58$ \\
\hline & .....do. & .....do. & $35-39$ & 2.0 & 8.6 & 17 & 23 & 1.9 & 12 & $<.58$ \\
\hline & .....do. & .....do. & $39-43$ & 2.7 & 6.0 & 12 & 10 & $<.32$ & 8.2 & $<.58$ \\
\hline & .....do. & .....do. & $43-47$ & 7.1 & 9.3 & 23 & 40 & 10 & 13 & .90 \\
\hline & .....do. & .....do. & $47-51$ & 6.9 & 8.2 & 21 & 30 & 5.5 & 12 & $<.58$ \\
\hline & .....do. & .....do. & $51-55$ & 3.3 & 6.0 & 16 & 18 & .70 & 8.2 & $<.58$ \\
\hline & .....do. & .....do. & $55-59$ & 2.7 & 4.3 & 2.7 & $<.51$ & $<.32$ & 5.4 & $<.58$ \\
\hline & .....do. & .....do. & $59-63$ & 13 & 12 & 9.7 & 43 & 9.2 & 13 & 1.8 \\
\hline & .....do. & .....do. & $63-67$ & 7.6 & 8.0 & 10 & 32 & 6.1 & 9.6 & .60 \\
\hline & .....do. & .....do. & $67-71$ & 8.7 & 8.0 & 22 & 34 & 11.0 & 11 & 1.5 \\
\hline & .....do. & .....do. & $71-75$ & 8.1 & 7.8 & 19 & 22 & .60 & 10 & $<.58$ \\
\hline & .....do. & .....do. & $75-78$ & 5.3 & 6.2 & 20 & 35 & 9.8 & 9.4 & 3.3 \\
\hline \multirow[t]{11}{*}{108} & .....do. & Upper Mystic River & 00-04 & $<.29$ & 1.9 & 5.9 & 8.3 & $<.32$ & 2.0 & $<.58$ \\
\hline & .....do. & .....do. & 04-08 & $<.29$ & 2.7 & 5.9 & 6.1 & $<.32$ & 2.8 & $<.58$ \\
\hline & .....do. & .....do. & $08-12$ & $<.29$ & $<.44$ & 4.6 & 1.4 & $<.32$ & $<.28$ & $<.58$ \\
\hline & .....do. & .....do. & $12-16$ & $<.29$ & 2.5 & 7.4 & 10 & $<.32$ & 2.6 & $<.58$ \\
\hline & .....do. & .....do. & $16-20$ & $<.29$ & .40 & 4.7 & 6.0 & $<.32$ & .40 & $<.58$ \\
\hline & .....do. & .....do. & $20-24$ & $<.29$ & .50 & 4.6 & 9.5 & $<.32$ & .50 & $<.58$ \\
\hline & .....do. & .....do. & $24-28$ & $<.29$ & $<.44$ & .40 & $<.51$ & $<.32$ & $<.28$ & $<.58$ \\
\hline & .....do. & .....do. & $28-32$ & $<.29$ & $<.44$ & .50 & $<.51$ & $<.32$ & $<.28$ & $<.58$ \\
\hline & .....do. & .....do. & $32-36$ & $<.29$ & .30 & 2.0 & $<.51$ & $<.32$ & .30 & $<.58$ \\
\hline & .....do. & .....do. & $36-40$ & $<.29$ & $<.44$ & 4.1 & 3.7 & $<.32$ & $<.28$ & $<.58$ \\
\hline & ......do. & .....do. & $40-44$ & $<.29$ & $<.44$ & 1.5 & 1.3 & $<.32$ & $<.28$ & $<.58$ \\
\hline \multirow[t]{15}{*}{109} & Malden & .....do. & 00-04 & $<.29$ & 3.7 & 8.4 & 13 & $<.32$ & 3.8 & $<.58$ \\
\hline & .....do. & .....do. & 04-08 & $<.29$ & .40 & 5.6 & 6.5 & $<.32$ & .40 & $<.58$ \\
\hline & .....do. & .....do. & 08-12 & $<.29$ & 5.2 & 6.6 & 7.5 & $<.32$ & 5.3 & $<.58$ \\
\hline & .....do. & .....do. & $12-16$ & $<.29$ & 6.2 & 8.8 & 18 & 7.2 & 6.4 & $<.58$ \\
\hline & ......do. & .....do. & $16-20$ & $<.29$ & 5.8 & 8.8 & 12 & $<.32$ & 6.0 & $<.58$ \\
\hline & .....do. & .....do. & $20-24$ & $<.29$ & 1.3 & 3.2 & .60 & $<.32$ & 1.3 & $<.58$ \\
\hline & .....do. & .....do. & $24-28$ & $<.29$ & $<.44$ & 2.6 & 2.5 & $<.32$ & $<.28$ & $<.58$ \\
\hline & .....do. & .....do. & $28-32$ & $<.29$ & 1.3 & 4.2 & 2.3 & $<.32$ & 1.4 & $<.58$ \\
\hline & .....do. & .....do. & $32-36$ & $<.29$ & $<.44$ & 4.1 & 1.3 & $<.32$ & $<.28$ & $<.58$ \\
\hline & ......do. & .....do. & $36-40$ & $<.29$ & 1.9 & 4.4 & 5.7 & $<.32$ & 1.9 & $<.58$ \\
\hline & .....do. & .....do. & $40-44$ & $<.29$ & $<.44$ & $<.29$ & $<.51$ & $<.32$ & $<.28$ & $<.58$ \\
\hline & .....do. & .....do. & 44-48 & $<.29$ & 4.5 & 7.6 & 9.7 & $<.32$ & 4.7 & $<.58$ \\
\hline & .....do. & .....do. & $48-52$ & $<.29$ & $<.44$ & 1.2 & $<.51$ & $<.32$ & $<.28$ & $<.58$ \\
\hline & .....do. & .....do. & $52-56$ & $<.29$ & .20 & 2.4 & 3.1 & $<.32$ & .20 & $<.58$ \\
\hline & .....do. & .....do. & $56-60$ & $<.29$ & 5.0 & 7.4 & 11 & $<.32$ & 5.2 & $<.58$ \\
\hline
\end{tabular}


Table 5. Distribution of organic compound concentrations measured in sediment core samples, Mystic River Basin, Massachusetts.-Continued

[Station number: USGS sample identifiers and geographical coordinates are given in table 1; sampling locations shown on figure 3. BHC, 1,2,3,4,5,6-hexachlorocyclohexane; DDD, dichlorodiphenyldichloroethane; DDE, dichlorodiphenyldichloroethylene; DDT, dichlorodiphenyltrichloroethane; do., ditto; LD, lab duplicate; MDL, method detection limit; No., number; PCBs, polychlorinated biphenyls; cm, centimeters; ppm, parts per million; \%, percent; <, actual value shown is less than the minimum reporting limit; --, not analyzed]

\begin{tabular}{|c|c|c|c|c|c|c|c|c|c|c|}
\hline $\begin{array}{c}\text { Station } \\
\text { No. }\end{array}$ & Town & Water body & $\begin{array}{l}\text { Depth } \\
\text { (cm) }\end{array}$ & $\begin{array}{c}\text { Anthra- } \\
\text { cene } \\
\text { (ppm) }\end{array}$ & $\begin{array}{c}\text { Benzo[a]- } \\
\text { anthra- } \\
\text { cene } \\
\text { (ppm) }\end{array}$ & $\begin{array}{l}\text { Benzo[b,k]- } \\
\text { fluoran- } \\
\text { thracene } \\
\text { (ppm) }\end{array}$ & $\begin{array}{l}\text { Benzo[a]- } \\
\text { pyrene } \\
\text { (ppm) }\end{array}$ & $\begin{array}{c}\text { Benzo }[g, h, i]- \\
\text { perylene } \\
\text { (ppm) }\end{array}$ & $\begin{array}{l}\text { Chrysene } \\
\text { (ppm) }\end{array}$ & $\begin{array}{l}\text { Dibenzo- } \\
{[a, h]-} \\
\text { anthra- } \\
\text { cene } \\
\text { (ppm) }\end{array}$ \\
\hline \multicolumn{11}{|c|}{ 109-Continued } \\
\hline & Malden & Upper Mystic River & $60-64$ & $<0.29$ & $<0.44$ & 2.4 & 2.3 & $<0.32$ & $<0.28$ & $<0.58$ \\
\hline & .....do. & .....do. & $72-76$ & $<.29$ & $<.44$ & 2.5 & 1.5 & $<.32$ & $<.28$ & $<.58$ \\
\hline & .....do. & .....do. & $76-80$ & $<.29$ & $<.44$ & .60 & $<.51$ & $<.32$ & $<.28$ & $<.58$ \\
\hline & .....do. & .....do. & $80-84$ & $<.29$ & $<.44$ & 4.1 & 1.5 & $<.32$ & $<.28$ & $<.58$ \\
\hline & .....do. & .....do. & $84-88$ & $<.29$ & 1.0 & 4.1 & 1.2 & $<.32$ & 1.0 & $<.58$ \\
\hline & .....do. & .....do. & $88-92$ & $<.29$ & $<.44$ & $<.29$ & $<.51$ & $<.32$ & $<.28$ & $<.58$ \\
\hline & .....do. & .....do. & $08-12$ & $<.29$ & $<.44$ & $<.29$ & $<.51$ & $<.32$ & $<.28$ & $<.58$ \\
\hline & .....do. & .....do. & $12-16$ & $<.29$ & $<.44$ & $<.29$ & $<.51$ & $<.32$ & $<.28$ & $<.58$ \\
\hline & .....do. & .....do. & $16-20$ & $<.29$ & $<.44$ & $<.29$ & $<.51$ & $<.32$ & $<.28$ & $<.58$ \\
\hline & .....do. & .....do. & $20-24$ & $<.29$ & $<.44$ & $<.29$ & $<.51$ & $<.32$ & $<.28$ & $<.58$ \\
\hline & .....do. & .....do. & $24-28$ & $<.29$ & $<.44$ & $<.29$ & $<.51$ & $<.32$ & $<.28$ & $<.58$ \\
\hline & .....do. & .....do. & $28-32$ & $<.29$ & $<.44$ & $<.29$ & $<.51$ & $<.32$ & $<.28$ & $<.58$ \\
\hline & .....do. & .....do. & $32-36$ & $<.29$ & $<.44$ & $<.29$ & $<.51$ & $<.32$ & $<.28$ & $<.58$ \\
\hline & .....do. & .....do. & $36-40$ & $<.29$ & $<.44$ & $<.29$ & $<.51$ & $<.32$ & $<.28$ & $<.58$ \\
\hline & .....do. & .....do. & $40-44$ & $<.29$ & $<.44$ & $<.29$ & $<.51$ & $<.32$ & $<.28$ & $<.58$ \\
\hline & .....do. & .....do. & $44-48$ & $<.29$ & $<.44$ & $<.29$ & $<.51$ & $<.32$ & $<.28$ & $<.58$ \\
\hline \multirow[t]{12}{*}{112} & Everett & Island End River & 00-04 & 5.2 & 4.2 & 12 & 5.9 & 3.2 & 4.9 & $<.58$ \\
\hline & .....do. & .....do. & 04-08 & 4.0 & 5.5 & 9.8 & 5.3 & 2.8 & 3.3 & $<.58$ \\
\hline & .....do. & .....do. & $08-12$ & 15 & 20 & 26 & 18 & 10 & 12. & 4.4 \\
\hline & .....do. & .....do. & $12-16$ & 1.4 & 3.6 & 6.8 & 3.5 & 1.5 & 2.9 & $<.58$ \\
\hline & .....do. & .....do. & $16-20$ & 2.8 & 6.2 & 11 & 6.1 & 3.5 & 4.1 & $<.58$ \\
\hline & .....do. & .....do. & $20-24$ & 4.6 & 10 & 15 & 9.8 & 4.8 & 7.2 & 2.1 \\
\hline & .....do. & .....do. & $24-28$ & 4.8 & 9.2 & 15 & 9.0 & 5.5 & 4.9 & 2.2 \\
\hline & .....do. & .....do. & $28-32$ & 5.2 & 12 & 17 & 11 & 5.3 & 7.4 & 2.2 \\
\hline & .....do. & .....do. & $32-36$ & 5.5 & 12 & 14 & 9.6 & 3.9 & 7.7 & 1.6 \\
\hline & .....do. & .....do. & $36-40$ & 53 & 59 & 57 & 37 & 15 & 37 & 7.9 \\
\hline & .....do. & .....do. & $40-44$ & 98 & 89 & 79 & 50 & 19 & 57 & 10 \\
\hline & .....do. & .....do. & $44-48$ & 57 & 75 & 68 & 44 & 15 & 49 & 8.1 \\
\hline
\end{tabular}


Table 5. Distribution of organic compound concentrations measured in sediment core samples, Mystic River Basin, Massachusetts.-Continued

[Station number: USGS sample identifiers and geographical coordinates are given in table 1; sampling locations shown on figure 3. BHC, 1,2,3,4,5,6-hexachlorocyclohexane; DDD, dichlorodiphenyldichloroethane; DDE, dichlorodiphenyldichloroethylene; DDT, dichlorodiphenyltrichloroethane; do., ditto; LD, lab duplicate; MDL, method detection limit; No., number; PCBs, polychlorinated biphenyls; cm, centimeters; ppm, parts per million; \%, percent; <, actual value shown is less than the minimum reporting limit; --, not analyzed]

\begin{tabular}{|c|c|c|c|c|c|c|c|c|c|c|}
\hline $\begin{array}{c}\text { Station } \\
\text { No. }\end{array}$ & Town & Water body & $\begin{array}{l}\text { Depth } \\
\text { (cm) }\end{array}$ & $\begin{array}{l}\text { Anthra- } \\
\text { cene } \\
\text { (ppm) }\end{array}$ & $\begin{array}{c}\text { Benzo[a]- } \\
\text { anthra- } \\
\text { cene } \\
\text { (ppm) }\end{array}$ & $\begin{array}{l}\text { Benzo }[\boldsymbol{b}, \boldsymbol{k}]- \\
\text { fluoran- } \\
\text { thracene } \\
\text { (ppm) }\end{array}$ & $\begin{array}{c}\text { Benzo[a]- } \\
\text { pyrene } \\
\text { (ppm) }\end{array}$ & $\begin{array}{c}\text { Benzo }[g, h, i]- \\
\text { perylene } \\
\text { (ppm) }\end{array}$ & $\begin{array}{c}\text { Chrysene } \\
\text { (ppm) }\end{array}$ & $\begin{array}{c}\text { Dibenzo- } \\
\text { [a,h]- } \\
\text { anthra- } \\
\text { cene } \\
\text { (ppm) }\end{array}$ \\
\hline \multirow[t]{4}{*}{ 105-LD } & Arlington & Lower Mystic Lake & $24-28$ & $<0.29$ & 0.60 & 4.5 & $<0.51$ & $<0.32$ & 1.2 & $<0.58$ \\
\hline & ....do. & ....do. & $24-28$ & $<.29$ & $<.44$ & 2.8 & $<.51$ & $<.32$ & 1.3 & $<.58$ \\
\hline & ....do. & ....do. & $89-93$ & $<.29$ & $<.44$ & .4 & $<.51$ & $<.32$ & $<.28$ & $<.58$ \\
\hline & ....do. & ....do. & $89-93$ & $<.29$ & $<.44$ & .3 & $<.51$ & $<.32$ & $<.28$ & $<.58$ \\
\hline \multirow[t]{2}{*}{ 106-LD } & .....do. & Upper Mystic River & $16-20$ & $<.29$ & .40 & 3.2 & $<.51$ & $<.32$ & 1.3 & $<.58$ \\
\hline & ....do. & ....do. & $16-20$ & $<.29$ & .50 & 3.7 & $<.51$ & $<.32$ & 1.6 & $<.58$ \\
\hline \multirow[t]{4}{*}{ 107-LD } & Medford & Malden River & $19.5-23$ & 4.8 & 8.6 & 25 & 41 & 13 & 13 & 1.6 \\
\hline & ....do. & ....do. & $19.5-23$ & 4.3 & 8.0 & 25 & 35 & 9.5 & 13 & 1.3 \\
\hline & ....do. & ....do. & $67-71$ & 6.7 & 6.5 & 18 & 30 & 9.1 & 9.6 & 1.6 \\
\hline & ....do. & .....do. & $67-71$ & 6.5 & 6.7 & 19 & 30 & 6.1 & 9.4 & 1.6 \\
\hline \multirow[t]{2}{*}{ 108-LD } & .....do. & Upper Mystic River & $36-40$ & $<.29$ & $<.44$ & 1.7 & .90 & $<.32$ & $<.28$ & $<.58$ \\
\hline & .....do. & ....do. & $36-40$ & $<.29$ & $<.44$ & 1.5 & $<.51$ & $<.32$ & $<.28$ & $<.58$ \\
\hline \multirow[t]{7}{*}{ 109-LD } & Malden & ....do. & $00-04$ & $<.29$ & 2.1 & 3.5 & 3.1 & $<.32$ & 2.1 & $<.58$ \\
\hline & ....do. & ....do. & $08-12$ & $<.29$ & 2.9 & 6.0 & 7.0 & $<.32$ & 1.9 & $<.58$ \\
\hline & ....do. & .....do. & $08-12$ & $<.29$ & 3.2 & 6.3 & 8.5 & $<.32$ & 3.3 & $<.58$ \\
\hline & ....do. & .....do. & $56-60$ & $<.29$ & 6.7 & 8.3 & 17 & $<.32$ & 6.9 & $<.58$ \\
\hline & ....do. & ....do. & $56-60$ & $<.29$ & 6.2 & 8.0 & 15 & $<.32$ & 6.4 & $<.58$ \\
\hline & ....do. & ....do. & $84-88$ & $<.29$ & $<.44$ & 1.4 & 1.0 & $<.32$ & $<.28$ & $<.58$ \\
\hline & .....do. & .....do. & $84-88$ & $<.29$ & 2.0 & 5.4 & 8.1 & $<.32$ & 2.1 & $<.58$ \\
\hline \multirow[t]{6}{*}{ 111-LD } & Boston & Lower Mystic River & $00-04$ & $<.29$ & .60 & 1.9 & .70 & $<.32$ & 1.1 & $<.58$ \\
\hline & .....do. & ....do. & $04-08$ & $<.29$ & $<.44$ & 2.2 & .80 & $<.32$ & .90 & $<.58$ \\
\hline & ....do. & ....do. & $08-12$ & $<.29$ & .60 & 2.2 & .60 & $<.32$ & .60 & $<.58$ \\
\hline & ....do. & ....do. & $12-16$ & .40 & $<.44$ & 3.2 & 1.7 & .50 & 1.6 & $<.58$ \\
\hline & .....do. & .....do. & $16-20$ & $<.29$ & $<.44$ & $<.29$ & $<.51$ & $<.32$ & $<.28$ & $<.58$ \\
\hline & .....do. & .....do. & $20-24$ & $<.29$ & $<.44$ & 1.6 & $<.51$ & $<.32$ & .50 & $<.58$ \\
\hline \multirow[t]{12}{*}{ 112-LD } & Everett & Island End River & $00-04$ & 5.2 & 3.7 & 7.3 & 5.0 & 2.3 & 4.2 & $<.58$ \\
\hline & ....do. & ....do. & $04-08$ & 4.4 & 6.8 & 12 & 7.8 & 3.5 & 5.0 & $<.58$ \\
\hline & ....do. & ....do. & $08-12$ & 13 & 21 & 23 & 17 & 6.3 & 12 & 3.2 \\
\hline & .....do. & .....do. & $12-16$ & 2.0 & 2.9 & 5.6 & 3.0 & 1.0 & 1.6 & $<.58$ \\
\hline & .....do. & .....do. & $16-20$ & 2.2 & 6.1 & 9.6 & 5.9 & 3.6 & 4.2 & $<.58$ \\
\hline & ....do. & .....do. & $20-24$ & 5.4 & 12 & 18 & 12 & 6.3 & 8.2 & 2.1 \\
\hline & ....do. & ....do. & $24-28$ & 3.9 & 9.2 & 15 & 9.4 & 5.0 & 4.8 & 1.4 \\
\hline & ....do. & .....do. & $28-32$ & 5.4 & 13 & 18 & 11 & 5.4 & 8.0 & 1.7 \\
\hline & .....do. & .....do. & $32-36$ & 7.1 & 12 & 17 & 11 & 5.2 & 8.2 & 1.6 \\
\hline & .....do. & .....do. & $36-40$ & 49 & 68 & 62 & 40 & 15 & 44 & 6.0 \\
\hline & .....do. & .....do. & $40-44$ & 86 & 91 & 73 & 42 & 16 & 59 & 8.4 \\
\hline & .....do. & .....do. & $44-48$ & 57 & 83 & 86 & 50 & 22 & 57 & 16.0 \\
\hline
\end{tabular}


Table 5. Distribution of organic compound concentrations measured in sediment core samples, Mystic River Basin, Massachusetts.-Continued

[Station number: USGS sample identifiers and geographical coordinates are given in table 1; sampling locations shown on figure 3. BHC, 1,2,3,4,5,6-hexachlorocyclohexane; DDD, dichlorodiphenyldichloroethane; DDE, dichlorodiphenyldichloroethylene; DDT, dichlorodiphenyltrichloroethane; do., ditto; LD, lab duplicate; MDL, method detection limit; No., number; PCBs, polychlorinated biphenyls; cm, centimeters; ppm, parts per million; \%, percent; <, actual value shown is less than the minimum reporting limit; --, not analyzed]

\begin{tabular}{|c|c|c|c|c|c|c|c|c|c|c|}
\hline $\begin{array}{c}\text { Station } \\
\text { No. }\end{array}$ & Town & Water body & $\begin{array}{l}\text { Depth } \\
\text { (cm) }\end{array}$ & $\begin{array}{c}\text { Fluor- } \\
\text { anthene } \\
\text { (ppm) }\end{array}$ & $\begin{array}{c}\text { Fluorene } \\
\text { (ppm) }\end{array}$ & $\begin{array}{c}\text { Indeno- } \\
{[1,2,3-c d]-} \\
\text { pyrene } \\
\text { (ppm) }\end{array}$ & $\begin{array}{l}\text { Naph- } \\
\text { thalene } \\
\text { (ppm) }\end{array}$ & $\begin{array}{c}\text { Phenan- } \\
\text { threne } \\
\text { (ppm) }\end{array}$ & $\begin{array}{c}\text { Pyrene } \\
\text { (ppm) }\end{array}$ & $\begin{array}{c}\text { Tribromo- } \\
\text { phenol } \\
\text { (\% recovery) }\end{array}$ \\
\hline \multirow[t]{18}{*}{105} & Arlington & Lower Mystic Lake & 00-04 & 20 & $<0.11$ & $<0.4$ & $<0.61$ & $<0.17$ & 9.7 & 85 \\
\hline & .....do. & .....do. & 04-08 & 14 & $<.11$ & $<.4$ & $<.61$ & 1.6 & 10 & 87 \\
\hline & .....do. & .....do. & 04-12 & 14 & $<.11$ & $<.4$ & $<.61$ & $<.17$ & 6.8 & 80 \\
\hline & .....do. & .....do. & $20-24$ & 13 & $<.11$ & $<.4$ & $<.61$ & $<.17$ & 14 & 70 \\
\hline & .....do. & .....do. & $24-28$ & 9.7 & $<.11$ & $<.4$ & $<.61$ & $<.17$ & 5.3 & 106 \\
\hline & .....do. & .....do. & $28-32$ & 32 & $<.11$ & $<.4$ & $<.61$ & 3.9 & 16 & 77 \\
\hline & .....do. & .....do. & $32-36$ & 19 & $<.11$ & $<.4$ & $<.61$ & 1.9 & 10 & 104 \\
\hline & .....do. & .....do. & $36-40$ & 27 & $<.11$ & 1.4 & $<.61$ & 2.3 & 14 & 73 \\
\hline & .....do. & ......do. & $53-57$ & 38 & $<.11$ & 3.1 & $<.61$ & 4.7 & 20 & 114 \\
\hline & .....do. & .....do. & $57-61$ & 44 & 2.9 & 8.4 & $<.61$ & 14 & 43 & 81 \\
\hline & .....do. & .....do. & $61-65$ & 69 & 15 & 15 & 1.0 & 29 & 67 & 86 \\
\hline & .....do. & .....do. & $65-69$ & 100 & 15 & 24 & 2.3 & 36 & 83 & 73 \\
\hline & .....do. & .....do. & $69-73$ & 120 & 19 & 25 & $<.61$ & 62 & 110 & 75 \\
\hline & .....do. & .....do. & $73-77$ & 270 & 66 & 62 & $<.61$ & 110 & 240 & 86 \\
\hline & .....do. & .....do. & $77-81$ & 140 & 7.8 & 25 & $<.61$ & 53 & 140 & 75 \\
\hline & .....do. & .....do. & $81-85$ & 100 & 7.1 & 21 & $<.61$ & 39 & 95 & 114 \\
\hline & .....do. & .....do. & $85-89$ & 25 & $<.11$ & $<.4$ & $<.61$ & 13 & 22 & 97 \\
\hline & .....do. & .....do. & 89-93 & 19 & $<.11$ & $<.4$ & $<.61$ & 3.8 & 9.3 & 120 \\
\hline \multirow{7}{*}{106} & .....do. & .....do. & $12-16$ & 5.3 & $<.11$ & $<.4$ & $<.61$ & $<.17$ & 5.4 & 54 \\
\hline & .....do. & .....do. & $16-20$ & 5.6 & $<.11$ & $<.4$ & $<.61$ & $<.17$ & 5.6 & 73 \\
\hline & .....do. & .....do. & $20-24$ & 4.8 & $<.11$ & $<.4$ & $<.61$ & $<.17$ & 5.5 & 79 \\
\hline & .....do. & .....do. & $24-28$ & 4.0 & $<.11$ & $<.4$ & $<.61$ & $<.17$ & 6.0 & 120 \\
\hline & .....do. & .....do. & $28-32$ & 2.1 & $<.11$ & $<.4$ & $<.61$ & $<.17$ & 4.9 & 108 \\
\hline & .....do. & .....do. & $32-36$ & 5.0 & $<.11$ & $<.4$ & $<.61$ & $<.17$ & 9.1 & 36 \\
\hline & .....do. & .....do. & $36-39$ & 4.6 & $<.11$ & $<.4$ & $<.61$ & $<.17$ & 8.4 & 102 \\
\hline \multirow[t]{5}{*}{107} & Medford & Malden River & 00-04 & 42 & $<.11$ & 5.5 & $<.61$ & 9.3 & 38 & 61 \\
\hline & .....do. & .....do. & 04-08 & 52 & $<.11$ & 2.1 & $<.61$ & 11 & 45 & 65 \\
\hline & .....do. & .....do. & $08-12$ & 56 & $<.11$ & 11 & $<.61$ & 14 & 50 & 80 \\
\hline & .....do. & .....do. & $12-16$ & 40 & $<.11$ & 5.9 & $<.61$ & 9.5 & 37 & 37 \\
\hline & .....do. & .....do. & $16-19.5$ & 54 & .40 & 11 & $<.61$ & 16 & 49 & 117 \\
\hline
\end{tabular}


Table 5. Distribution of organic compound concentrations measured in sediment core samples, Mystic River Basin, Massachusetts.-Continued

[Station number: USGS sample identifiers and geographical coordinates are given in table 1; sampling locations shown on figure 3. BHC, 1,2,3,4,5,6-hexachlorocyclohexane; DDD, dichlorodiphenyldichloroethane; DDE, dichlorodiphenyldichloroethylene; DDT, dichlorodiphenyltrichloroethane; do., ditto; LD, lab duplicate; MDL, method detection limit; No., number; PCBs, polychlorinated biphenyls; cm, centimeters; ppm, parts per million; \%, percent; <, actual value shown is less than the minimum reporting limit; --, not analyzed]

\begin{tabular}{|c|c|c|c|c|c|c|c|c|c|c|}
\hline $\begin{array}{c}\text { Station } \\
\text { No. }\end{array}$ & Town & Water body & $\begin{array}{c}\text { Depth } \\
(\mathrm{cm})\end{array}$ & $\begin{array}{l}\text { Fluor- } \\
\text { anthene } \\
\text { (ppm) }\end{array}$ & $\begin{array}{c}\text { Fluorene } \\
\text { (ppm) }\end{array}$ & $\begin{array}{l}\text { Indeno- } \\
{[1,2,3-c d]-} \\
\text { pyrene } \\
\text { (ppm) }\end{array}$ & $\begin{array}{l}\text { Naph- } \\
\text { thalene } \\
\text { (ppm) }\end{array}$ & $\begin{array}{c}\text { Phenan- } \\
\text { threne } \\
\text { (ppm) }\end{array}$ & $\begin{array}{c}\text { Pyrene } \\
\text { (ppm) }\end{array}$ & $\begin{array}{c}\text { Tribromo- } \\
\text { phenol } \\
\text { (\% recovery) }\end{array}$ \\
\hline
\end{tabular}

107-Continued Medford

.....do.

Malden River

$\begin{array}{rr}19.5-23 & 48 \\ 23-27 & 40 \\ 27-31 & 42 \\ 31-35 & 44 \\ 35-39 & 46 \\ 39-43 & 30 \\ 43-47 & 50 \\ 47-51 & 43 \\ 51-55 & 29 \\ 55-59 & 20 \\ 59-63 & 56 \\ 63-67 & 39 \\ 67-71 & 48 \\ 71-75 & 42 \\ 75-78 & 29\end{array}$

0.70

12

\section{$<0.61$}

$<.11$

5.0

$$
<.61
$$

....do. $\quad$....do.

.....do. $\quad$....do.

.....do. $\quad$.....do.

.....do. $\quad$.....do.

.....do. $\quad$.....do.

.....do. $\quad$.....do.

....do. $\quad$.....do.

.....do. $\quad$....do.

.....do. $\quad$.....do.

.....do. $\quad$.....do.

.....do. $\quad$.....do.

.....do. $\quad$.....do.

.....do.

.....do.

108

.....do. Upper Mystic River

......do. .....do.

.....do. .....do.

.....do. .....do.

......do. .....do.

......do. ......do.

......do. ......do.

......do. $\quad$......do.

......do. .....do.

.....do. $\quad$......do.

.....do. $\quad$.....do.

109

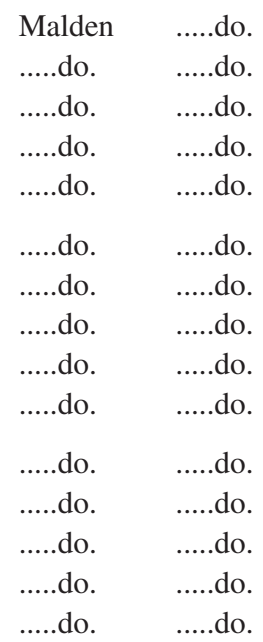

00-04

04-08

08-12

12-16

$16-20$

20-24

24-28

28-32

32-36

$36-40$

40-44

3.5

1.5

1.5

$<.61$

$<.61$

$<.61$

$<.11$

.40

$<.11$

$<.11$

$<.11$

6.8

.70

4.5

.80

1.5

$<.11$

$<.11$

$<.11$

$<.11$

$<.11$

$<.11$

$$
4.3
$$

$<.12$

$<.11$

$<.11$

$<.11$

$<.11$

$<.11$

00-04

04-08

08-12

12-16

16-20

$<.12$

$$
2.3
$$

$$
6.4
$$

5.9

6.8

$<.11$

$<.11$

$<.11$

.6

$<.4$
6.0

$<.61$

$<.61$

$<.61$

$<.61$

$<.61$

$<.61$

$<.61$

$<.61$

$<.61$

$<.61$

$<.61$

$<.61$

$<.61$

$<.61$

$<.61$

$<.61$

$<.61$

$<.61$

$<.61$

$<.61$

$<.61$

$<.61$

$<.61$

$<.61$

$<.61$

$<.61$

$<.61$

$<.61$

$<.61$

$<.61$

$<.61$

$<.61$

$<.61$

$<.61$

$<.61$

$<.61$

$<17$

$<.17$

$<.17$

$<.17$

$<.17$

$<.17$

$<.17$

$<.17$

$<.17$

$<.17$

$<.17$

$<.17$

$<.17$

$<.17$

$<.17$

$<.17$

$<.17$

$<.17$

$<.17$

$<.17$

$<.17$

$<.17$

$<.17$

$<.17$

$<.17$

52-56

1.0

$<.11$

$<.4$

\begin{tabular}{|c|c|}
\hline 43 & 45 \\
\hline 37 & 96 \\
\hline 40 & 55 \\
\hline 44 & 118 \\
\hline 43 & 111 \\
\hline 29 & 47 \\
\hline 44 & 93 \\
\hline 38 & 100 \\
\hline 29 & 55 \\
\hline 13 & 104 \\
\hline 50 & 111 \\
\hline 37 & 64 \\
\hline 42 & 75 \\
\hline 40 & 80 \\
\hline 29 & 105 \\
\hline 7.9 & 66 \\
\hline 6.6 & 51 \\
\hline 4.6 & 81 \\
\hline 6.5 & 75 \\
\hline 5.8 & 58 \\
\hline 6.6 & 60 \\
\hline 2.7 & 70 \\
\hline 1.2 & 53 \\
\hline 5.5 & 74 \\
\hline 5.3 & 71 \\
\hline 5.5 & 79 \\
\hline 6.3 & 46 \\
\hline 5.9 & 31 \\
\hline 7.4 & 35 \\
\hline 10 & 93 \\
\hline 11 & 108 \\
\hline 8.1 & 149 \\
\hline 3.9 & 44 \\
\hline 5.2 & 104 \\
\hline 5.0 & 91 \\
\hline 5.0 & 80 \\
\hline 1.3 & 84 \\
\hline 8.3 & 76 \\
\hline 4.8 & 95 \\
\hline 3.8 & 80 \\
\hline 12 & 99 \\
\hline
\end{tabular}

$<.11$

$<.4$

$<.17$ 
Table 5. Distribution of organic compound concentrations measured in sediment core samples, Mystic River Basin, Massachusetts.-Continued

[Station number: USGS sample identifiers and geographical coordinates are given in table 1; sampling locations shown on figure 3. BHC, 1,2,3,4,5,6-hexachlorocyclohexane; DDD, dichlorodiphenyldichloroethane; DDE, dichlorodiphenyldichloroethylene; DDT, dichlorodiphenyltrichloroethane; do., ditto; LD, lab duplicate; MDL, method detection limit; No., number; PCBs, polychlorinated biphenyls; cm, centimeters; ppm, parts per million; \%, percent; <, actual value shown is less than the minimum reporting limit; --, not analyzed]

\begin{tabular}{|c|c|c|c|c|c|c|c|c|c|c|}
\hline $\begin{array}{c}\text { Station } \\
\text { No. }\end{array}$ & Town & Water body & $\begin{array}{c}\text { Depth } \\
\text { (cm) }\end{array}$ & $\begin{array}{l}\text { Fluor- } \\
\text { anthene } \\
\text { (ppm) }\end{array}$ & $\begin{array}{c}\text { Fluorene } \\
\text { (ppm) }\end{array}$ & $\begin{array}{c}\text { Indeno- } \\
{[1,2,3-c d]-} \\
\text { pyrene } \\
\text { (ppm) }\end{array}$ & $\begin{array}{l}\text { Naph- } \\
\text { thalene } \\
\text { (ppm) }\end{array}$ & $\begin{array}{c}\text { Phenan- } \\
\text { threne } \\
\text { (ppm) }\end{array}$ & $\begin{array}{c}\text { Pyrene } \\
\text { (ppm) }\end{array}$ & $\begin{array}{c}\text { Tribromo- } \\
\text { phenol } \\
\text { (\% recovery) }\end{array}$ \\
\hline
\end{tabular}

109-Continued

Malden

......do.

......do.

Upper Mystic River

.....do.

......do.

......do.

.....do. $\quad$.....do

.....do. $\quad$.....do.

.....do. .....do

.....do. $\quad$.....do.

.....do. $\quad$.....do.

110 Somerville Lower Mystic River

.....do. $\quad$.....do.

.....do. $\quad$.....do

.....do. $\quad$.....do.

.....do. $\quad$.....do.

.....do. $\quad$.....do.

.....do. $\quad$.....do.

.....do. $\quad$.....do

.....do. $\quad$.....do.

.....do. $\quad$.....do.

.....do. $\quad$.....do.

.....do. $\quad$.....do.

111 Boston .....do.

.....do. .....do

.....do. $\quad$.....do

.....do. $\quad$......do

.....do. $\quad$.....do.

.....do. $\quad$.....do.

112 Everett Island End River

.....do. $\quad$.....do.

.....do. $\quad$.....do.

.....do. $\quad$.....do.

.....do. $\quad$.....do.

.....do. $\quad$.....do.

.....do. $\quad$.....do.

.....do. $\quad$.....do.

.....do. $\quad$.....do.

.....do. $\quad$.....do.

.....do. $\quad$.....do.

.....do. $\quad$.....do.

$$
\begin{aligned}
& 60 \\
& 6 \\
& 68 \\
& 72 \\
& 76 \\
& 80 \\
& 8 \\
& 8 \\
& 9
\end{aligned}
$$$$
64-68
$$$$
68-72
$$$$
72-76
$$$$
76-80
$$$$
\text { 80-84 }
$$$$
\text { 84-88 }
$$$$
\text { 88-92 }
$$$$
\text { 92-96 }
$$

00-04

04-08

08-12

12-16

16-20

20-24

24-28

28-32

32-36

36-40

40-44

44-48

00-04

04-08

08-12

12-16

16-20

20-24

00-04

04-08

08-12

12-16

16-2

20-24 31

24-28

28-32

32-36 35

36-40 220

40-44 370

44-48 260

$\begin{array}{lll}2.6 & <0.11 & <0.4 \\ 3.9 & <.11 & <.4 \\ 3.4 & <.11 & <.4 \\ <.12 & <.11 & <.4 \\ <.12 & <.11 & <.4 \\ & & \end{array}$

$$
<0
$$$$
<.4
$$$$
<.4
$$$$
<.4
$$$$
<.4
$$$$
<.4
$$$$
<.4
$$$$
<.4
$$$$
<.4
$$$$
<.4
$$$$
<.4
$$$$
<.4
$$$$
<.4
$$$$
<.4
$$$$
<.4
$$$$
<.4
$$$$
<.4
$$$$
<.4
$$$$
<.4
$$$$
<.4
$$$$
<.4
$$$$
1.5
$$$$
.6
$$$$
\begin{array}{r}
.6 \\
.8
\end{array}
$$$$
.9
$$$$
<.4
$$$$
<.4
$$$$
3.3
$$$$
2.7
$$$$
12
$$$$
1.4
$$$$
4.1
$$$$
5.8
$$$$
5.5
$$$$
6.0
$$$$
4.5
$$$$
18
$$$$
22
$$$$
78
$$$$
35
$$

\section{$<0.61$}

$<.61$

$<.61$

$<.61$

$<.61$

$<.61$

$<.61$

$<.61$

$<.61$

$<.61$

$<.61$

$<.61$

$<.61$

$<.61$

$<.61$

$<.61$

$<.61$

$<.61$

$<.61$

$<.61$

$<.61$

$<.61$

$<.61$
$<.61$

$<.61$

$<.61$

$<.61$

$<.61$
$<0.17$

$<.17$

$<.17$

$<.17$

$<.17$

$<.17$

$<.17$

$<.17$

$<.17$

$<.17$

$<.17$

$<.17$

$<.17$

$<.17$

$<.17$

$<.17$

$<.17$

$<.17$

$<.17$

$<.17$

$<.17$

$<.17$

$<.17$

$<.17$

.70

$<.17$

$<.17$

4.9

4.6

3.1

1.0

2.7

\section{5}

6.4

6.1

4.5

3.2

$$
6.7
$$

7.6

6.0

6.0

$<.05$

$<.05$

$<.05$

$<.05$

2.1

1.9

$$
4.0
$$

$$
1.5
$$$$
2.9
$$$$
<.05
$$

$$
<.05
$$

$$
2.2
$$

$$
4.5
$$

$$
2.1
$$

$$
\begin{aligned}
& 2.1 \\
& 2.4
\end{aligned}
$$$$
\begin{aligned}
& 2.4 \\
& 3.4
\end{aligned}
$$$$
2.2
$$$$
2.5
$$

13

20

20
48

10

17

3.2

25

25
19

28

25

140

220

160

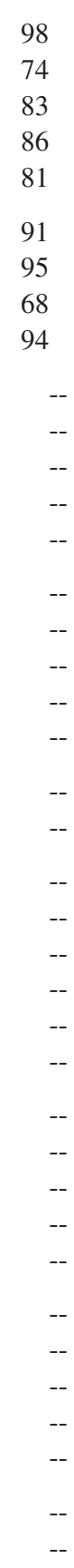


Table 5. Distribution of organic compound concentrations measured in sediment core samples, Mystic River Basin, Massachusetts.-Continued

[Station number: USGS sample identifiers and geographical coordinates are given in table 1; sampling locations shown on figure 3. BHC, 1,2,3,4,5,6-hexachlorocyclohexane; DDD, dichlorodiphenyldichloroethane; DDE, dichlorodiphenyldichloroethylene; DDT, dichlorodiphenyltrichloroethane; do., ditto; LD, lab duplicate; MDL, method detection limit; No., number; PCBs, polychlorinated biphenyls; cm, centimeters; ppm, parts per million; \%, percent; <, actual value shown is less than the minimum reporting limit; --, not analyzed]

\begin{tabular}{|c|c|c|c|c|c|c|c|c|c|c|}
\hline $\begin{array}{c}\text { Station } \\
\text { No. }\end{array}$ & Town & Water body & $\begin{array}{c}\text { Depth } \\
\text { (cm) }\end{array}$ & $\begin{array}{l}\text { Fluor- } \\
\text { anthene } \\
\text { (ppm) }\end{array}$ & $\begin{array}{c}\text { Fluorene } \\
\text { (ppm) }\end{array}$ & $\begin{array}{c}\text { Indeno- } \\
{[1,2,3-c d]-} \\
\text { pyrene } \\
\text { (ppm) }\end{array}$ & $\begin{array}{l}\text { Naph- } \\
\text { thalene } \\
\text { (ppm) }\end{array}$ & $\begin{array}{c}\text { Phenan- } \\
\text { threne } \\
\text { (ppm) }\end{array}$ & $\begin{array}{c}\text { Pyrene } \\
\text { (ppm) }\end{array}$ & $\begin{array}{c}\text { Tribromo- } \\
\text { phenol } \\
\text { (\% recovery) }\end{array}$ \\
\hline \multirow[t]{4}{*}{ 105-LD } & Arlington & Lower Mystic Lake & $24-28$ & 12 & $<0.11$ & $<0.4$ & $<0.61$ & $<0.17$ & 6.1 & 106 \\
\hline & ....do. & ....do. & $24-28$ & 13 & $<.11$ & $<.4$ & $<.61$ & $<.17$ & 6.6 & 108 \\
\hline & ....do. & ....do. & $89-93$ & 18 & $<.11$ & $<.4$ & $<.61$ & 3.3 & 9.4 & 91 \\
\hline & .....do. & .....do. & $89-93$ & 20 & $<.11$ & $<.4$ & $<.61$ & 4.5 & 9.8 & 120 \\
\hline \multirow[t]{2}{*}{ 106-LD } & ....do. & Upper Mystic River & $16-20$ & 6.0 & $<.11$ & $<.4$ & $<.61$ & $<.17$ & 5.2 & 72 \\
\hline & .....do. & ....do. & $16-20$ & 5.0 & $<.11$ & $<.4$ & $<.61$ & $<.17$ & 5.0 & 76 \\
\hline \multirow[t]{4}{*}{ 107-LD } & Medford & Malden River & $19.5-23$ & 44 & $<.11$ & 10 & $<.61$ & 12 & 40 & 44 \\
\hline & .....do. & ....do. & $19.5-23$ & 47 & $<.11$ & 6.5 & $<.61$ & 12 & 42 & 55 \\
\hline & ....do. & ....do. & 67-71 & 38 & 4.4 & 5.9 & $<.61$ & 14 & 34 & 89 \\
\hline & .....do. & .....do. & $67-71$ & 43 & 2.6 & 4.5 & $<.61$ & 14 & 37 & 96 \\
\hline \multirow[t]{2}{*}{ 108-LD } & ....do. & Upper Mystic River & $36-40$ & 2.8 & $<.11$ & $<.4$ & $<.61$ & $<.17$ & 5.1 & 56 \\
\hline & ....do. & ....do. & $36-40$ & .90 & $<.11$ & $<.4$ & $<.61$ & $<.17$ & 5.0 & 63 \\
\hline \multirow[t]{7}{*}{ 109-LD } & Malden & .....do. & $00-04$ & 7.9 & $<.11$ & $<.4$ & $<.61$ & $<.17$ & 8.1 & 53 \\
\hline & .....do. & .....do. & $08-12$ & 5.9 & $<.11$ & $<.4$ & $<.61$ & $<.17$ & 5.9 & 85 \\
\hline & .....do. & .....do. & $08-12$ & 5.1 & $<.11$ & 1.2 & $<.61$ & $<.17$ & 5.9 & 70 \\
\hline & .....do. & ....do. & $56-60$ & 8.3 & $<.11$ & $<.4$ & $<.61$ & $<.17$ & 12 & 83 \\
\hline & .....do. & .....do. & $56-60$ & 6.8 & $<.11$ & $<.4$ & $<.61$ & $<.17$ & 11 & 76 \\
\hline & ....do. & ....do. & $84-88$ & 1.6 & $<.11$ & $<.4$ & $<.61$ & $<.17$ & 7.4 & 48 \\
\hline & .....do. & .....do. & 84-88 & 3.2 & $<.11$ & $<.4$ & $<.61$ & $<.17$ & 7.6 & 61 \\
\hline \multirow[t]{6}{*}{ 111-LD } & Boston & Lower Mystic River & $00-04$ & 3.3 & $<.11$ & $<.4$ & $<.61$ & $<.17$ & 3.4 & -- \\
\hline & .....do. & ....do. & $04-08$ & 1.3 & $<.11$ & .4 & $<.61$ & $<.17$ & 2.7 & -- \\
\hline & ....do. & ....do. & $08-12$ & 1.6 & $<.11$ & $<.4$ & $<.61$ & $<.17$ & 2.6 & -- \\
\hline & ....do. & ....do. & $12-16$ & 2.2 & $<.11$ & $<.4$ & $<.61$ & $<.17$ & 3.5 & -- \\
\hline & ....do. & ....do. & $16-20$ & 1.8 & $<.11$ & $<.4$ & $<.61$ & $<.17$ & 2.7 & -- \\
\hline & .....do. & .....do. & $20-24$ & 1.0 & $<.11$ & $<.4$ & $<.61$ & $<.17$ & 2.2 & -- \\
\hline \multirow[t]{12}{*}{ 112-LD } & Everett & Island End River & $00-04$ & 14 & $<.11$ & 2.8 & $<.61$ & 5.9 & 12 & -- \\
\hline & .....do. & ....do. & $04-08$ & 14 & $<.11$ & 4.4 & $<.61$ & 3.6 & 20 & -- \\
\hline & ....do. & ....do. & $08-12$ & 58 & $<.11$ & 8.5 & $<.61$ & 2.1 & 50 & -- \\
\hline & ....do. & ....do. & $12-16$ & 6.4 & $<.11$ & 1.2 & $<.61$ & 1.2 & 10 & -- \\
\hline & .....do. & .....do. & $16-20$ & 11 & $<.11$ & 3.1 & $<.61$ & 1.3 & 16 & -- \\
\hline & ....do. & ....do. & $20-24$ & 31 & $<.11$ & 6.8 & $<.61$ & 3.1 & 25 & -- \\
\hline & ....do. & .....do. & $24-28$ & 18 & $<.11$ & 5.1 & $<.61$ & 1.6 & 18 & -- \\
\hline & .....do. & .....do. & $28-32$ & 35 & $<.11$ & 6.4 & $<.61$ & 2.7 & 27 & -- \\
\hline & ....do. & .....do. & $32-36$ & 34 & $<.11$ & 6.0 & $<.61$ & 4.4 & 24 & -- \\
\hline & .....do. & .....do. & $36-40$ & 240 & 17 & 19 & $<.61$ & 18 & 140 & -- \\
\hline & .....do. & .....do. & $40-44$ & 340 & 60 & 19 & $<.61$ & 120 & 220 & -- \\
\hline & ....do. & ....do. & $44-48$ & 260 & 30 & 28 & $<.61$ & 89 & 160 & -- \\
\hline
\end{tabular}

